UNIVERSITY OF LATVIA

Baltic
LATVIJAS UNIVERSITĀTE

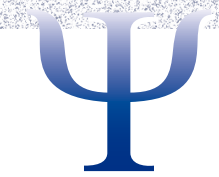

\title{
JOURNAL OF PSYCHOLOGY
}

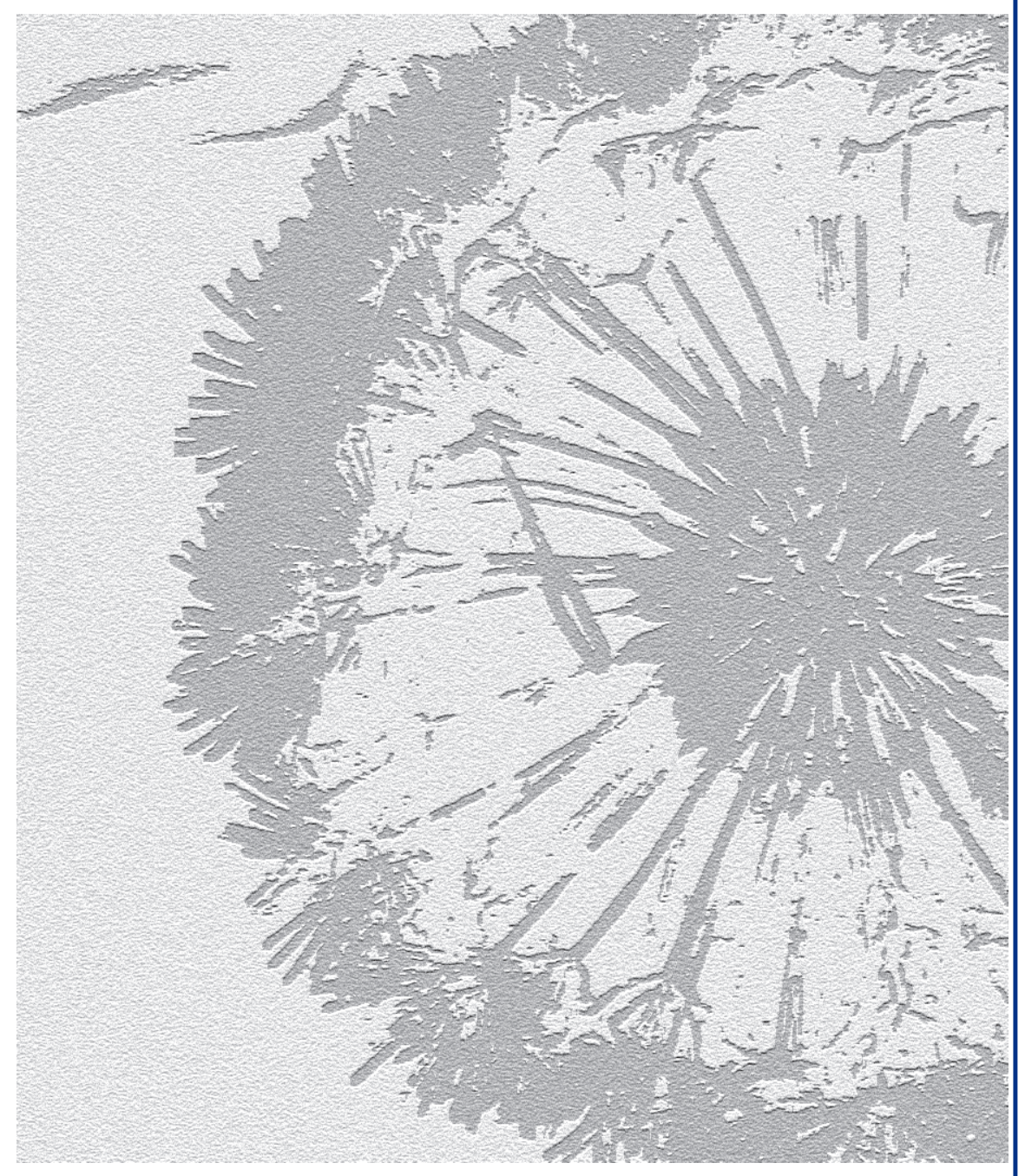

2016, Vol. 17, No. 1, 2 


\section{BALTIC JOURNAL OF PSYCHOLOGY \\ BALTIJAS PSIHOLOG̣IJAS ŽURNĀLS}

2016, Volume 17, Number 1 \& 2

\section{EBSCO database Academic Search Complete}

\section{Editor}

Ivars Austers, Ph.D., University of Latvia

Sandra Sebre, Ph.D., University of Latvia

\section{Editorial Assistant}

Baiba Upite, Mg. izgl. vad., University of Latvia

\section{Members of the International Editorial Board}

Albinas Bagdonas, Ph.D., Vilnius University, Lithuania

Imants Barušs, Ph.D., University of Western Ontario, Canada

Linas A. Bieliauskas, Ph.D., University of Michigan Medical Center, USA

Ieva Bite, Dr. Psych., University of Latvia, Latvia

Arthur Cropley, Ph.D., University of Hamburg, Germany, Australia

Ģirts Dimdiņš, Ph.D., University of Latvia, Latvia

Juris G. Draguns, Ph.D., Pennsylvania State University, University Park, USA

Shane R. Jimerson, Ph.D., NCSP University of California, Santa Barbara, USA

Ilze Kalninšs, Ph.D., University of Toronto, Canada

Rimas Kočiunas, Ph.D., Vilnius University, Lithuania

Aleksandrs Koḷesovs, Dr. Psych., University of Latvia, Latvia

Alfredas Laurinavičius, Ph.D., Vilnius University, Lithuania

Anika Miltuze, Dr. Psych., University of Latvia, Latvia

Risto Naatanen, Ph.D., University of Tartu, Estonia

Anita Pipere, Dr. Psych., Daugavpils University, Latvia

Aldis Putniňš, Ph.D., University of South Australia, Australia

Malgožata Raščevska, Dr. Psych., University of Latvia, Latvia

\section{Authors should submit manuscripts to:}

Prof. Sandra Sebre

Department of Psychology,

Faculty of Education, Psychology and Art,

University of Latvia,

Jurmalas gatve 76

Riga, Latvia, LV 1083

Phone, fax: 371-67034018

E-mail: baltic.journ.psych@lu.lv

Editorial assistant: Baiba Upìte

Layout and cover design: The University of Latvia Press

ISSN 1407 - 768X

(C) Department of Psychology, University of Latvia, 2016

https://doi.org/10.22364/bjp.17.01-02

Subscription from the homepage: http://www.lu.lv/bpz/eng 


\section{Contents}

Laimes izjūtu veicinošo stratēǵiju izmantošanas ietekme

uz subjektīvās labklājības rādītājiem

Effect of Happiness Enhancing Strategies on Subjective Well-Being Indicators

Katrīna Žaltkovska, Anda Upmane

Nepatieso pārliecību izpratne un spēja apvaldìt reakcijas 3-5 gadus veciem bērniem Preschool Children's (3-5 years) Inhibitory Control and False Belief Understanding Kristiāna Kalninga, Anika Miltuze

Mātes zināšanas par bērna attīstību, audzināšanu un izjustais sociālais atbalsts pēc piedalīšanās vecāku apmācības programmā "Bērnu emocionālā audzināšana" Mother's Knowledge About Child Development, Parenting and Perceived Social Support After Participation in the Parent Training Program "Encouraging Children's Healthy Emotional Development"

Aiga Ukstinga, Laura Pirsko

Ģimenes locekḷa alkohola atkarības pieredzes bērnībā, uzvedības īpatnības, stresa pārvarēšanas stratēgijas un traumatiskā pagātnes pieredze Internalizing and Externalizing Behavior, Coping Strategies, Traumatic Childhood Events and Experience of Alcohol Addicted Family Member in Childhood

Iveta Damroze, Laura Pirsko

Datorspēlı prosociālas vai agresīvas lomas spēlēšanas ietekme uz jauniešu agresīvām izjūtām un prosociālo spriešanu Videogame Prosocial and Aggressive Role Playing Effects on Youths' Anger and Prosocial Reasoning

Mihails Limonovs, Sandra B. Sebre

Skolotāju skaidrojumi par skolēnu problemātiskās uzvedības motīviem un par savām reakcijām uz skolēnu problemātisko uzvedību Teacher's Atributions of Student Misbehavior and Responses to it Signe Knipše, Baiba Martinsone. 100

Noguruma un gulētiešanas laika novilcināšanas saistība ar prokrastināciju skolotājiem

Teachers' Fatigue and Bedtime Delay in Relation to Procrastination

Ginta Slišāne, Baiba Martinsone

Personality traits, perceived social support and self-efficacy in people with and without chronic disease 


\title{
Laimes izjūtu veicinošo stratēgiju izmantošanas ietekme uz subjektīvās labklājỉbas rādītājiem
}

\author{
Katrīna Žaltkovska un Anda Upmane ${ }^{1}$
}

Latvijas Universitāte

\begin{abstract}
Abstrakts
Pētījuma mērḳis bija realizēt eksperimentu, lai noskaidrotu, vai pēc dalības 4 nedēḷu ilgā programmā, kuras laikā tās dalībnieki veica 4 dažādas laimes izjūtu paaugstinošas aktivitātes, būs vērojama laimes izjūtas līmeṇa paaugstināšanās. Pētījumā piedalījās 145 respondenti (kontroles grupa $n=75$, eksperimentālā grupa $n=70$ ) vecumā no 18 līdz 74 gadiem. Abās grupās tika veikti subjektīvās laimes izjūtas mērījumi (Subjective Happiness Scale, Lyubomirsky, \& Lepper, 1999) pirms un pēc dalības pētījumā. Pētījuma rezultāti liecina, ka ir vērojamas statistiski nozīmīgas, pozitīvas izmaiņas laimes izjūtas radītājos pēc dalības laimes programmā eksperimentālajā grupā. Var izvirzìt pieṇēmumu, ka dalība laimes programmā ir paaugstinājusi subjektīvās laimes izjūtas līmeni eksperimentālajā grupā. Kontroles grupas laimes izjūtas līmeṇa rādītājos izmaiṇas nav statistiski nozīmīgas.
\end{abstract}

Atslēgas vārdi: laimes izjūta, laimes izjūtu paaugstinošās stratēégijas, stratēégiju efektivitāte, Subjektīiās laimes skala.

\section{Effect of Happiness Enhancing Strategies on Subjective Well-Being Indicators}

\section{Katrina Žaltkovska and Anda Upmane}

Univeristy of Latvia

\begin{abstract}
The aim of the study was to conduct an experiment to examine if participation in a 4-week program, during which time the participants carry out happiness enhancing activities, will boost the level of happiness scores. The study included 145 respondents (control group $n=75$, experimental group $n=70$ ) aged 18 to 74 years. Measurements from both groups with the Subjective Happiness Scale (Lyubomirsky \& Lepper, 1999) were obtained before and after participation in the study. The results of the study in showed statistically significant, positive changes in Subjective Happiness Scale scores after participation in the happiness program for the experimental group. This suggests that participation in the happiness enhancing program has raised the level of subjective happiness. There were no statistically significant changes in the Subjective Happiness Scale scores for the control group.
\end{abstract}

Keywords: happiness, happiness enhancing strategy, effectiveness of strategies, Subjective Happiness Scale.

Corresponding author: Anda Upmane, University of Latvia, Jurmalas gatve 76, Riga LV-1083, Latvia. Email: anda.upmane@lu.lv 
Laimes izjūta ir lıti subjektīvs jēedziens un ikviens vērtē savus dzīves notikumus un apstākḷus caur savu subjektīvo laimes uztveri un izpratni. Tomēr joprojām ir interese, vai pastāv kāda universāla iespēja kā ikviens spētu kḷūt laimīgāks? Pētỉjuma ietvaros tiks apskatîts vai pastāv zinātniski pamatotas stratēǵijas, ar kuru palīdzību ikviens var mēg̣ināt paaugstināt savu subjektīvo laimes izjūtu.

Tiekšanos pēc laimes var uzskatīt par cilvēka dabisku vēlmi, tāpēc ir vērts izzināt dažādas, reāli pielietojamas stratēǵijas laimes izjūtas paaugstināšanai. Pētnieki Maijers un Dīners (Myer \& Diener, 1995) uzsver, ka psiholog̣ija kā zinātne ir par maz koncentrējusies uz tādām pozitīvām psihologiskām izjūtām kā apmierinātība un laime. Tāpat tiek izvirzìts uzskats, ka par psihologiijas mērḳi vajadzētu būt spējai palīdzēt paaugstināt cilvēka laimes izjūtu (Seligman, Steen, Park, \& Peterson, 2005). N̦emot vērā, ka pētījumi par cilvēku laimes izjūtu un iespējām to paaugstināt jau kādu laiku ir aktuāli, tad šì pētījuma mêrķis ir apkopot šobrīd zināmās laimes izjūtu paaugstinošās stratẹgijas, to realizācijas nosacījumus un gūt priekšstatu par to efektivitāti, kā arī, balstoties uz iepriekš veiktajiem pètijumiem un eksperimentiem (Lyubomirsky, et al., 2005; Seligman, et al., 2005, Gander, Proyer, Ruch, \& Wyss, 2013; Schueller, 2011), realizēt laimes programmu 4 nedệlu garumā, kuras laikā tās dalībnieki regulāri praktizēs dažādas laimes izjūtu veicinošās stratégijas. Šì programma, salīdzinot ar iepriekš veiktajiem pētijumiem, tika realizēta vienkāršotā formā. Saziņa ar dalïbniekiem notika reizi nedēlāa, ar e-pasta starpniecību. Pieteikties šai programmai varēja aizpildot aptauju, kas tika izveidota bezmaksas aptauju veidošanas platformā. Informācija par šo programmu tika izplatīta sociālajā vietnē www.facebook.com. Šìs programmas realizēšanai bija zemas izmaksas (datora un interneta pieejamība), tāpat arī pati dalība programma bija bez maksas. Galvenā ideja, bija novērot vai šādā veidā organizēta laimes programma, kas neprasa daudz resursus ne izveidotājiem, ne dalībniekam, cilvēkiem ir saistoša un var veicināt laimes izjūtas pieaugumu.

\section{Subjektīvās labklājỉbas jeb laimes izjūtas skaidrojums}

Pētijumos un dažādu autoru darbos jēdzieni "subjektīvā labklājìiba" un "laimes izjūta” visbiežāk tiek lietoti kā sinonīmi (Diener, 1984; Lyubomirsky, Sheldon, \& Schkade, 2005) un arī turpmāk šajā rakstā tiks izmantoti.

Subjektīvā labklājība ietver sevī indivīda apmierinātības ar dzīvi vērtējumu, biežu pozitīvo afektu un retu negatīvo afektu esamību (Diener; 1984; Myer \& Diener, 1995). Laimes izjūtu var apskatìt gan kā personības iezīmi, gan kā šì briža stāvokli. Personības iezīmes nosaka to, kāds būs izjusto afektu (emociju) intensitātes līmenis (Diener, 1984). Daļai cilvēku raksturīgi augsti kāpumi un kritumi emociju intensitātē, turpretim ir indivīdi, kuriem ir tendence justies vairāk laimīgiem nekā nelaimīgiem, citiem vairāk skumjiem. Tāpat ir indivīdi, kuriem nav tendences spēcīgi izdzīvot nevienas no emocijām un kuriem varētu piedēvēt emociju trūkumu (Myer \& Diener, 1995).

Pētījumos jau zināmu laiku tiek meklētas atbildes uz jautājumu, kas nosaka cilvēka laimes izjūtu un apmierinātību ar dzìvi. Lai arī parādās atseviški faktori, kas ietekmē cilvēka subjektīvo labklājỉbu, kopumā laime un apmierinātība ar dzīvi ir līdzvērtīgi sasniedzama neatkarīgi no vecuma, dzimuma, rases vai ieņemamā amata (Myer \& Diener, 1995). Piemēram, ir zināms, ka ienākumu līmenis pozitīvi saistās ar 
subjektīvo labklājību, taču tas nav viennozīmīgs rādìtājs un ienākumu pozitīiā ietekme vērojama līdz brīdim, kad vidēji ir nodrošinātas un apmierinātas visas indivīda dzīves pamatvajadzïbas (Myer \& Diener, 1995; Suh \& Oishi, 2002). Tāpat dati liecina, ka individuālisma kultūrās dzīvojošie ir laimīgāki nekā kolektīvisma kultūru pārstāvji, tomēr starpkultūru pētījumi rāda, ka liela nozīme ir tam, kā katrā kultūrā ir definēta laime un cik nozīmīga tā ir indivìdu līmenī (Suh \& Oishi, 2002). Tālāk tiks apskatītas dažādas pieejas, kas skaidro laimi nosakošos faktorus.

\section{Augšupejošā (bottom up) un lejupejošā (top-down) pieeja}

Vēsturiski eksistē divas atšķirīgas pieejas, kas skaidro faktorus, kas determinē laimi - augšupejošā (bottom up) un lejupejošā (top-down) pieeja (Diener, 1984).

Augšupejošā pieeja skaidro, ka laime ir balstīta uz indivīda dzīves apstākḷiem, ikdienas veiksmēm un grūtībām, tāpat ir saistìta ar sociāli ekonomisko stāvokli, izglìtỉbas lìmeni, fizisko veselību un demogrāfiskajiem faktoriem - vecumu, dzimumu, rasi (Lyubomirsky, King, \& Diener, 2005). Tātad, subjektīvo labklājību veido dažādu ārēju faktoru summa. Attiecinot šo pieeju uz diskusiju par to, kas ir nozīmīgāks - iedzimtîba vai vide, augšupejošā pieeja raksturo pozīciju, ka nozīmīgāka ir vide un dažādi mainīgi apstākḷi. Arvien vairāk autoru, veicot pētijumus un analizējot SL pētījumu vēsturi, ir nonākuši pie secinājuma, ka objektīvi apstākḷi, demogrāfiskie mainīgie un dzīves notikumi nekorelē ar SL tik cieši kā tas tika uzskatīts labklājības pētijumu pirmsākumos. Pētnieki uzskata, ka visi iepriekšminētie faktori kopā izskaidro ne vairāk kā 8-15\% SL variācijas (Diener \& Lucas, 1999).

Lejupejošajā pieejā valda uzskats, ka laimes izjūtu indivīdā neizraisa ārēji mainīgi apstākḷi (piemēram, objektīivi novērojami cilvēka dzīves apstākḷi), bet laime drīzāk saistāma ar biologiskiem vai temperamenta faktoriem, kas tiešã veidā ietekmē uzvedību un kognitīvās spējas. Šì pieeja ir attīstījusies no uzvedības genētikas pētījumiem (Tellegen, Lykken, Bouchard, Wilcox, Segal, \& Rich, 1988). Šajos pētijumos apstiprinājās, ka identiskie vienas olšūnas dvīṇi ir ar līdzīgu subjektīvās labklājības līmeni, salīdzinot ar divu olšūnu dvinniem, neatkarīgi no tā, vai vinni auguši kopā vienā ğimenē vai šķirti. Veiss ar kolēgiem apjomīgā dvinnu pētijumā guva pārsteidzošu apstiprinājumu hipotēzei, ka subjektīvo labklājību nenosaka kādi noteikti atsevišḳi gēni, bet gan par to ir "atbildīga" tā pati gēnu kombinācija, kas nosaka ekstraversijas, neirotisma un mazākā mērā apzinīguma individuālās atškịiribas (Weiss, Bates, \& Luciano, 2008). Uzskatot iedzimtību par svarīgāko subjektīvās labklājības ietekmējošo faktoru, netiek noliegts, ka vides ietekme ir svarīga, bet tomēr tiek skaidrots, ka vide vairāk ietekmē garastāvokli, neatstājot nozīmīgas izmaiņas ilgākā laika posmā (Nes, Røysamb, Tambs, Harris, \& Reichborn-Kjennerud, 2006). Lejupejošā pieeja tālāk tiek apstiprināta personības iezīmju pētījumos (Steel, Schmidt, \& Shultz, 2008). Tajos visbiežāk parādās nozīmīgas subjektīvās labklājības korelācijas ar ekstraversiju un neirotismu, bet ar pārējām personības iezīmēm no Lielā Piecinieka šì saistība ir pastarpināta. Piemēram, Denēva un Kūpers secināja, ka augsts apzinīgums un labvēlīgums veicina pozitīvākas pieredzes gūšanu un tādā veidā paaugstina subjektīvo labklàjību, bet atvērtība pieredzei ar subjektīvo labklājību ir saistīta nenozīmīgi (DeNeve \& Cooper, 1998).

Apvienojot abas pieejas, var teikt, ka augšupejošās pieejas izvirzìtie faktori, piemēram, sociāli ekonomiskais stāvoklis, var ietekmēt to, kā mainās indivīda subjektīvās 
labklājības līmenis, bet lejupejošās pieejas faktori, piemēram, iedzimtība un personības iezīmes, nosaka, kādu attieksmi un spriedumus izvirzīsim par notiekošo.

\section{Laimes konstruēšanas modelis}

Laimes konstruēšanas modelis balstās uz lejupejošo pieeju, bet reizē ietver arī nozīmīgus augšupejošās pieejas faktorus (Lybomirsky \& Dickerhoof, 2011). Tiek uzsvērts, ka laimes izjūtu nosaka gan tas, kāds ir indivīda gimenes stāvoklis vai mēneša ienākumi, gan tas, kādas ir šì indivīda temperamenta iezīmes (piemēram, vai indivīds ir vairāk intraverts vai ekstraverts) (Lyubomirsky, 2001). Subjektīvās labklājības kopējais vērtējums balstās uz indivīda objektīvo un sociālo pasauli, un viṇa paša subjektīvo interpretāciju par to. Modelis neizslēdz ārējo apstākḷu ietekmi uz laimes izjūtu, jo cilvēks ir aktīvs ārējo apstākḷu interpretētājs un reakciju veidotājs, un, jo optimistiskāks būs skatījums uz apstākḷiem, jo augstāks būs subjektīvās labklājības līmenis (Lyubomirsky, 2001; Lybomirsky \& Dickerhoof, 2011).

Lubomirska ar kolēgiem (Lyubomirsky, Sheldon, \& Schkade, 2005) savos pētījumos meklē, kādas ir indivīda iespējas būt laimīgākam par spīti spēcīgajai genētisko faktoru, personības ietekmei un adaptācijai dažādiem dzives notikumiem. Apkopojot gan pētijumus par adaptāciju, gan dzīves notikumiem un personības ietekmi, L,ubomirska ar kolēgiem izvirza priekšplānā pieņēmumu, ka laimes izjūtu nosaka 50\% iedzimtība (ǵenētiski determinēts, stabils laimes izjūtas līmenis), 10\% nosaka situācija un apstākḷi (ienākumu līmenis, ǵimenes stāvoklis, religíiozitāte un citi) un $40 \%$ ir indivīda paša apzināta aktivitāte, kas ir būtiska laimes izjūtai (Lyubomirsky, et al., 2005). Lai arī iedzimtība un apstākḷi procentuāli nosaka daudz, tiek uzsvērts, ka tieši apzinātās aktivitātes, kurās persona iesaistās, var daudz spēcīgāk ietekmēt reālo laimes izjūtu. Longitudinālie pētijumi uzrāda, ka personīgo mērķu izvirzišana un augsta centība to sasniegšanas procesā paaugstina subjektīvo labklājību. Tāpat laimes izjūtu paaugstina tādas uzvedības praktizēšana kā piedošana, pateicība un laipnība (Lyubomirsky, et al., 2005; Otake, Shimai, Tanaka-Matsumi, Otsui, \& Fredrickson, 2006).

\section{Laimes izjūtas uzlabošanas iespēju pētniecības aizsākumi}

Lai arī iepriekš minētie pētijumi, kas norāda uz personības iezīmju un genētisko faktoru lielo ietekmi uz subjektīvo labklājību atstāj samērā pesimistisku iespaidu attiecībā uz indivīda iespējām paaugstināt savu labklājỉbu, pirmie pētỉjumi un atklājumi, ka laimes izjūtu var paaugstināt, tika veikti 20. gadsimta 70. un 80. gados (Fordyce, 1977, 1983). Trijos eksperimentos 1977. gadā Forduse (Fordyce, 1977) apskatīja, vai iespējams paaugstināt laimes izjūtu. Izvēēēās laimes veicinošās stratēǵijas autors balstīja uz "dabiski" laimīgāku cilvēku raksturojumu un piedāvāja tādas aktivitātes, kas vērstas uz socializēšanos, optimistiskāku domāšanu un mērḳu izvirzǐšanu. Pētījumu dalībniekiem bija vērojamas vismaz nelielas laimes izjūtas izmaiņas pozitīvā virzienā. Pat ja laimes izjūtas līmenis nepaaugstinājās, tas arī nepazeminājās, izṇemot vienu gadỉjumu. Tiem dalībniekiem, kas sevi pozicionēja kā "dabiski” laimīgus, šo uzdevumu efektivitāte bija zemāka vai pat netika novērota, jo veicamie uzdevumi sakrita ar to, ko šie respondenti jau realizē savā ikdienā.

Šo pētījumu rezultāti pirmo reizi apstiprināja, ka laimes izjūtu neietekmē tikai darbs, finansiālais stāvoklis, veselība un apmierinātība ar gimenes dzìvi, bet arī paša 
cilvēka attieksme un uzvedība, kuru ir iespējams mainīt (Fordyce, 1977). Balstoties uz atkārtotiem pètījumiem 1983. gadā un kopumā apvienojot datus par septiniem pētijjumiem, $81 \%$ dalībnieku norādīja uz laimes līmeņa paaugstināšanos (dažādās pakāpēs). Tāpat dalībnieki norādīja uz garastāvokḷa uzlabošanos, labākām spējām tikt galā ar sliktu garastāvokli, uzvedības un attieksmju maiṇu, dzīvesveida maiṇu un labāku sevis izpratni (Fordyce, 1983).

\section{Laimes izjūtu veicinošās stratēǵijas}

Balstoties uz to, ka laimīgus cilvēkus var raksturot kā pateicīgus, pozitīvi domājošus un tādus, kas iesaistās prosociālā uzvedībā, pozitīvās psiholog̣ijas jomā ir apzinātas darbības, kas varētu paaugstināt laimes izjūtu. Šìs pozitīiās darbības tiek definētas kā vienkāršas, tīši un regulāri praktizētas, lai imitētu veselīgas domas un uzvedību, kas vērojama dabiski laimīgos cilvēkos. Šīs kognitīvās un biheiviorālās stratēǵijas atspoguḷo laimīgu cilvēku rīcíbas (Lyubomirsky, 2001; Layous \& Lyubomirsky, 2012; Lyubomirsky \& Layous, 2013). Pamatā laimes izjūtas paaugstināšanas stratēgijas balstās uz divu faktoru kombināciju - palīdzēt cilvēkiem pozitīvāk apskatìt un novērtēt savus dzīves apstākḷus, kā arī dot iespēju pieredzēt vairāk pozitīvas un mazāk negatīvas emocijas (Schueller \& Parks, 2014). Lai arī gēni un personības iezīmes ietekmē un it kā uztur konstantu indivìda subjektīvo labklājības līmeni, pètījumi liecina, ka iesaistoties laimi veicinošās aktivitātēs ir iespējams paaugstināt šo līmeni uz nozīmīgu laika posmu (Lyubomirsky, et al., 2005).

Pētījumu metaanalīze, kurā apskatīja 51 pozitīvas psiholoǵijas intervenci, kas bija saistīta ar pozitīvu afektu veicināšu vai laimes izjūtu paaugstināšanu, pārsvarā apstiprināja, ka šīs intervences nozīmīgi paaugstina subjektīvas labklājỉbas līmeni un mazina depresijas simptomus. Apkopojot datus, tika secināts, ka, ja no 200 nejauši izvēlētiem cilvēkiem izveidos divas grupas - kontroles un eksperimentālo (katrā grupā 100 respondentu), tad 64 cilvēkiem no eksperimentālās grupas, kurā viṇi praktizēs kādu no laimes stratēgijām, pieaugs laimes izjūtas līmenis. Kontroles grupā, kurās praktizēs kādu neitrālu aktivitāti, laimes izjūtas līmenis pieaugs tikai 36 respondentiem(Sin \& Lyubomirsky, 2009).

Pētijumi rāda, ka laimes izjūtas paaugstināšanās dažādu aktivitāšu rezultātā nav skaidrojama tikai kā placebo efekts, un laimes izjūtas paaugstināšanas programmas ir daudz efektīvākas, kad dalībnieki ir informēti - saprot eksperimenta īsto mērḳi un pilnvērtīgi to realizēe, ir jānotiek apzinātai iesaistei šajā procesā (Lyubomirsky, Dickerhoof, Boehm, \& Sheldon, 2011). Pētijumi rāda, ka dalībnieki, kas piedalijās laimes izjūtu paaugstinošās aktivitātēs, bet nebija informēti, ka galvenais fokuss ir laimes izjūtas līmeņa paaugstināšana, uzrādīja vājākus un laikā mazāk noturīgus šīs izjūtas uzlabojumus salīdzinot ar pētijumiem, kuros dalībnieki bija informēti. Var izvirzìt apgalvojumu, ka potenciāli svarīgs laimes moderators ir pašas intervences mērķa un savas motivācijas apzināšanās (Lyubomirsky, et al., 2011).

Pozitīvās aktivitātes ir relatīvi îsas, tās ir pašvadìtas (self-adminired), pamatā ar mērḳi veicināt pozitīvas domas, sajūtas un pozitīvu uzvedību (Layous \& Lyubomirsky, 2012). Kopumā izdala trīs aktivitāšu veidus - kognitīvās aktivitātes, ar uzvedību saistītās aktivitātes un uz mērḳi balstītās jeb "apzinātās gribas" aktivitātes (Lyubomirsky \& 
Sheldon, 2011). Balstoties uz literatūru, stratēéijas sīkāk tiek dalītas piecās kategorijās (1) izbaudīšanas pieredzes un sajūtu stratēgijas; (2) stratēǵijas, kuras veicina pateicības izjūtas izkopšanu un izpaušanu; (3) stratẹgijas, kuras ietver laipnību paušana vai labu darbu veikšanu; (4) stratēgiijas pozitīvu starppersonu attiecību veicināšanai; (5) stratēǵijas, kas saistās ar cerību īstenošanu, jēgas pieškiršanu (Schueller \& Parks, 2014).

Laimi veicinošās aktivitātes var kategorizēt arī pēc to mērḳa orientācijas. Tās var būt uz sevi orientētas (piemēram, optimisma praktizēšana), tā arī uz citiem orientētas (piemēram, pateicības paušana). Kolektīvisma kultūras pārstāvji lielāku ieguvumu gūst no uzdevumiem, kas ir vairāk uz citiem orientēti, individuālisti - uz sevi orientētiem (Boehm, Lyubomirsky, \& Sheldon, 2011). Daļa uzdevumu vairāk ir derīgi sociāli atvērtiem cilvēkiem, citi, kā piemēram, savu laimīgo mirkḷu atkārtota novērtēšana, būs patīkamāki intravertiem, noslēgtiem cilvēkiem. Jau uzsākot pētijumus, Forduse (Fordyce, 1977, 1983) norādīja, ka stratēgijas nav visiem vienādi derīgas un to efektivitāte indivīdu līmenī bija dažāda. Stratēgíijas piemērotỉba indivīdam ir saistìta ar viña motīviem, pamata vajadzībām un vērtībām, "stiprajām pusēm", resursiem un citām raksturojošām iezīmēm (Lyubomirsky, et al., 2005). Eksistē arī pieejas, kas uzskata, ka ir stratēǵijas, kas var būt derīgas visiem, jo tās nodrošina universālas psiholog̣iskas vajadzības - piederību, pašefektivitāti un autonomiju - kas nepieciešamas ikvienam (Deci \& Ryan, 2000).

Pozitīvās stratēgijas izšķir arī pēc orientācijas laikā. Pateicības izteikšana saistīta ar orientāciju uz pagātni, mirkḷa apzināta izbaudīšana saistīta ar orientāciju uz tagadni, bet optimistiskā domāšana - uz nākotni. Gados vecāki cilvēki lielāku labumu gūs no orientācijas uz pagātni, novērtējot savu dzīves mantojumu, tur pretim jaunāki - veroties uz savu nākotni (Lyubomirsky, \& Layous, 2013).

Iepazīstoties ar laimes uzlabošanas iespēju pētniecības aizsākumiem, Forduse (Fordyce, 1977), balstoties uz "dabiski" laimīgu cilvēku raksturojumu un ikdienas aktivitātēm, izvirzīja deviñas tehnikas, kas paaugstina laimes izjūtu. Tehnikas var iedalīt trīs kategorijās - uzvedības (biežāka socializēšanās), kognitīvās (optimistiska domāšana, orientācija uz nākotni) un apzinātās gribas (savu lietu organizēšana, plānošana). Nesenākos pètījumos kā efektīvas stratēgijas ir minētas pateicības vizītes, kas ir pateicības vēstuḷu rakstǐšana un tās nodošana adresātam (Lyubomirsky, et al., 2011; Seligman, et al., 2005), pateicību skaitīšanu (piemēram, "Paldies par to, ka esmu vesels!"), laipnības izpausmes, savu stipro pušu attīstī̌sana (Lyubomirsky, et al., 2005; Seligman, et al., 2005), savas nākotnes ideālā tēla vizualizācijas (Layous, Nelson, \& Lyubomirsky, 2012), meditēšana (meditācijas procesā koncentrējoties uz pozitīvām izjūtām pret sevi un citiem) (Fredrickson, Cohn, Coffey, Pek, \& Finkel, 2008), laika dāvana (Seligman, Rashid, \& Parks, 2006), izbaudī̌ana (Schueller, 2011; Kurtz \& Lyubomirsky, 2013).

Iepriekš uzskaitītās aktivitātes balstās tikai uz paša cilvēka reālām darbībām, un to rezultāts ir sava dzīves skatījuma maiņa. Pētījumi liecina, ka cilvēki kḷuva laimīgāki pēc, piemēram, pateicību izteikšanas vai optimisma realizēšanas tāpēc, ka šīs aktivitātes veicina savas dzīves interpretēšanu pozitīvākā skatījumā, un pētỉjuma gaitā apstiprinājās, ka objektīvie indivīda dzīves apstākḷi nav mainījušies (Lyubomirsky, et al., 2011).

Seligmans ar kolēgiem (Seligman, et al., 2005) interneta vidē veiktā pētījumā pārbaudīja piecu laimes veicinošu stratēgiiju efektivitāti, ja tās realizē vienu nedēlu. 
Viena no piedāvātajām stratēgijām bija "Trīs labas lietas", kas nozīmē, ka dienas beigās jāuzraksta trīs pozitīvas lietas vai notikumi, kas notikuši, jāapraksta to iespējamie iemesli un cēloṇsakarības. Rezultāti šo uzrādīja kā vienu no efektīvākajām stratēgijām. Labo notikumu apzināšana un izskaidrošana ir arī citos pētijjumos apstiprinās kā efektīva stratēǵija, kas paaugstinu laimes izjūtu. Šì intervence veicina pozitīvas emocijas un, ja tiek veidota dienasgrāmata, kurā pieraksta šos notikumus, tad ir iespējams šìs pozitīvās emocijas izdzīvot atkārtoti, pārlasot dienasgrāmatas ierakstus (Emmons, \& McCullough, 2003; Gander, et al., 2013). Ganders ar kolēgiem (Gander, et al., 2013) modificēja "Trīs labo lietu" stratēǵiju un sava pētījuma dalībniekiem piedāvāja stratēgiju "Trīs smieklīgas lietas", kas nozīmē, ka jāpieraksta trīs smieklīgas lietas, kuras piedzīvoja vai paveica dienas laikā, un arī jāizskaidro, kāpēc tās notikušas. Arī šì stratēǵija paaugstināja laimes izjūtu un pazemināja depresijas simptomus līdz pat sešiem mēnešiem pèc dalības intervencè (Gander, et al., 2013).

Laipnības izpausmes jeb laipnības aktu skaitī̌ana ir stratēgijia, kuras izpildes laikā katru dienu jāpieraksta visas laipnības vai labos darbus, kurus indivīds paveicis (Otake, et al., 2006). Laipnības aktu pētijumos ir pārbaudīti dažādi veidi, kā šo stratēǵiju var realizēt - gan tie, kuri neprasa nekādas izmaksas - durvju pieturēšana, komplimenta izteikšana, gan tie, kas prasa izmaksas, piemēram, dāvanu pirkšana. Vieni no efektīvākajiem uzskatāmi prosociālie tēriņi - tēriņiem priekš citiem cilvēkiem. Salīdzinot ar naudas tērēšanu sev, naudas tērēšana citiem izraisa laimes izjūtas pieaugumu (Dunn, Aknin, \& Norton, 2008).

Stratēgija "Laika dāvana" aicina uzdāvināt savu laiku kontaktējoties vai satiekoties ar cilvēkiem, kuras indivīdam rūp vai ir svarīgas. Šìm satikšanās reizēm jābūt speciāli ieplānotām, nevis ierastām (Gander, et al., 2013). Šì uzdevuma ietvaros var attīstīt arī savas stiprās puses (skatìt nākamo stratēǵiju), veltot laiku cilvēkiem vai realizējot sevi jomās, kas padodas, piemēram, bērnu pieskatī̌sana vai sabiedriskais un brīvprātīgais darbs (Seligman, et al., 2006).

Pirms tiek realizēta "stipro pušu attīstī̌sanas" stratēgija dalībniekam ir jāapzina piecas savas stiprās puses izmantojot tam paredzētu aptauju (Values in Action Survey of Strengths, Seligman, \& Peterson, 2004, kā minēts Seligman, et al., 2005). Apzinot savas stirpās puses, katru dienu ir jāmeklē jauns veids, kā realizēt vienu no šīm piecām stiprajām pusēm. Pētījumi apstiprina, ka savu stipro pušu realizēšana paaugstina laimes izjūtu un samazina depresijas simptomus (Seligman, et al., 2005).

Laimes intervenču laikā tiek praktizēta arī "izbaudīšanas” stratēǵija, kuru var iedalīt divās kategorijas - tās stratēgijas, kas māca un attīsta vispārējās spējas un principus kā baudìt un, tās, kas māca konkrētas baudišanas prasmes, mudina šìs iemaņas izmantot. Šì uzdevuma laikā dalībniekam lūdz katru dienu 2-3 minūtes veltìt divām patîkamām darbībām vai izjūtām, tās apzināti izbaudot (piemēram, karstās šokolādes dzeršanai). Mērḳis ir likt apzināti pievērsties sajūtām un patīkamajām emocijām. Izbaudīšanas brīdī notiek fokusēšanās uz pozitīvo notikumu un šis fokuss nepieciešams, lai paildzinātu tā brī̌̌a pozitīvās emocijas (Bryant, \& Veroff, 2006, kā minēts Hurley, \& Kwon, 2012; Schueller, 2011).

Intervencēs tiek izmantota arī cita izbaudī̌anas stratēgiija - "apzinātā fotogrāija”, kuras ietvaros katru dienu, vismaz 15 minūtes, ir jāuzṇem fotogrāfijas, kas ir radošas, 
skaistas un, kurām ir personīga nozīme (mịḷākā grāmata, tuvākais draugs, sporta ekipējums). Pētījuma dalībniekiem, kuri divas nedēḷas uzṇēma "apzinātās fotogrāfijas", bija novērojams ievērojami pozitīvāks noskaņojums, nekā tiem dalībniekiem, kuri arī uzṇēma fotogrāfijas, bet nesaṇēma konkrētus norādījumus par radošumu, skaistumu un personīgo nozīmīgumu (Kurtz \& Lyubomirsky, 2013). Lai arī izbaudīšana tiek raksturota kā fokuss uz šì brīža pozitīvajām sajūtām, tomēr te novērojama orientācija laikā un mēdz izdalīt trīs veidus kā klasificē izbaudī̌nanu - izbaudot caur paredzēěanu (iespējamos notikumus, nākotnes vīzijas, tā izjūtot pozitīias izjūtas tagadnē), izbaudot savas pozitīiās atmiņas un izbaudot šì brǐža momentu (Bryant, 1989, 2003).

Pateicības izteikšana veicina vispārēju šis izjūtas radǐšanu sevī. Pateicības stratēgijas ietvaros katras dienas beigās jāuzraksta trīs lietas, kas izdevās vai bija labas šajā dienā un, kāpēc tās ir izdevušās (fokusējoties uz pateicību par to). Novērtēšana, pozitīvā akcentēšana mazina pierašanu pie notikumiem, tie netiek uztverti kā pašsaprotami, tā zaudējot savu emocionāli pozitīvo nozīmi (Emmons, 2008, kā minēts Schueller, 2011). Pateicību skaitīšana ir apstiprināts kā efektīvs uzdevums subjektīvas labklājības izjūtas paaugstināšanai (Emmons \& McCullough, 2003; Seligman, et al., 2005). Pētijumi liecina, ka tāda iezīme, kā pateicība ir pozitīvi saistīta ar patîkamām atmiņām. Pateicība tika saistìta gan ar apzinātām un ar nodomu atsauktām atmiņām, gan negaidīti prātā ienākušām. Rezultāti liecina, ka patīkamas atmiņas nāk prātā vairāk pateicīgiem cilvēkiem. Tas ir arī veids, kā pateicība veicina subjektīvo labklājỉbu. Pateicīgs indivīds sev biežāk atgādina patîkamos notikumus līdz ar to vairāk savu dzīvi vērtē kā apmierinošu (Watkins, Grimm, \& Kolts, 2004). Rodas jautājums, vai pateicīgi cilvēki vairāk skaita to, par ko ir pateicīgi vai šiem cilvēkiem ir vairāk lietu un notikumu, par kuriem būt pateicīgiem? Pētījumi (dzīves notikumu saraksta pārbaude) uzrāda, ka pateicīgiem cilvēkiem ir kopumā bijusi labāka dzīve. Paužot pateicību, indivīds gūst daudz vairāk sociālus labumus - prosociālu rīcību pret sevi un arī veicina prosociāli rīcību tālāk (McCullough, Kilpatrick, Emmons, \& Larson, 2001).

Pateicības vizìte ir uzdevums, kura laikā dalïbnieks tiek aicināts uzrakstīt pateicības vēstuli kādam, kuram nav pietiekami pateicies. Dalībniekam ir jātiekas ar šo cilvēku un jānolasa vēstule (Seligman, 2002, kā minēts Seligman, et al., 2005). Šì tehnika, balstoties uz pētījumiem, rada vislielākās izmainas, salīdzinot ar citām tehnikām - paaugstinās laimes izjūta un samazinās depresijas simptomi (Lyubomirsky, et al., 2011; Seligman, et al., 2005).

Sava nākotnes ideālā tēla vizualizācijas (Layous, et al., 2012) jeb "Labākā iespējamā $E s$ ” stratēégijas pielietošanas laikā respondentiem lūdz vizualizēt un aprakstīt savu turpmāko "ideālo dzīvi” cik vien sīki iespējams (Sheldon \& Lyubomirsky, 2006). Instrukcija paredz, ka jāizvēlas, precīzi jāraksturo un jārada plāns, kā sasniegt mērkịi, kā novērst iespējamos šķēršşus, apskatīt visus iespējamos risinājumus un galu galā pārskatīt īstenošanas plānu (MacLeod, Coates, \& Hetherton, 2008). Dalībnieki, kas to rakstīja vairāk kā četras nedẹlas, piedzīvoja pozitīvo emociju pieaugumu, uzrādīja augstāku interesi un motivāciju kopumā, salīdzinot ar kontroles grupu, kas rakstija tikai par dzīves notikumiem (King, 2001; Sheldon \& Lyubomirsky, 2006). Jāatzīmē, ka šis uzdevums deva skaidrību un izpratni par mērḳiem, tajā notika mērḳu apzināšanās, bet netika sniegts atbalsts šo mērḳu îstenošanai darbībā (King, 2001; Sheldon \& Lyubomirsky, 2006). 


\section{Laimes intervenču efektivitātes nosacijumi}

Veiktie pētỉjumi par laimes izjūtas intervencēm atklāj, ka ilgtspējīgu laimes izjūtas paaugstināšanos var panākt tad, ja tiek ievēroti vairāki svarīgi komponenti: indivīdam jābūt motivētam, gatavam iesaistīties brīvprātīgi un jāpieliek apzināta piepūle, veicot uzdevumus. Tāpat svarīga ir neatlaidība un izvēlētās aktivitātes pierādìtā, pētỉjumos balstītā iedarbība (Sheldon \& Lyubomirsky, 2004; Lyubomirsky, et al., 2005).

Motivācija ir l̦oti nozīmīgs elements laimes stratēgiju efektivitātei. Paša motivēta iesaistī̌̌anās šajās intervencēs būtiski paaugstina laimes izjūtu intervences beigās. Atsevišķos pētijumos laimes stratēégiju efektivitāte bija novērojama tikai tiem dalībniekiem, kuri bija motivēti paaugstināt savu laimes izjūtas līmeni. L̦ubomirskas un kolēgu (Lyubomirsky, et al., 2011) pētījumā tika izveidotas trīs grupas, divas eksperimentālās, kuras realizēja tādas stratēgijas, kā pateicību paušanu un optimismu, un viena kontroles grupa, kura katru nedēlı uzskaitija ikdienā piedzīvotos notikumus. Grupas, kuras realizēja laimes stratēgijas, uzrādīja nozīmīgu subjektīvās labklājības līmen̦a paaugstināšanos salīdzinot ar kontroles grupu, bet jāṇem vērā, ka tas bija novērojams tikai tiem eksperimentālās grupas dalībniekiem, kuri bija motivēti iesaistīties laimes intervencē. Iespējams, tie dalïbnieki, kuri piedalījās laimes izjūtas paaugstināšanas intervencēs, bet nebija brīvprātīgi tās meklējuši vai izvēlējušies, jau bija ar pietiekami augstu subjektīvas labklājības izjūtu un nejuta vajadzību to paaugstināt (Seligman, et at., 2005). Tāpat arī tiek izvirzīta ideja, ka gadījumos, kad dalībnieki nav brīvprātīgi pieteikušies uz laimi veicinošo stratēǵiju intervencēm, viṇi uz šìm aktivitātēm raugās ar skepsi, netic to iedarbībai un tas arī kavē reālo uzlabojumu gūšanu (Lyubomirsky, et al., 2011). Pētījumi parāda, ka tie, kas apzināti meklē iespēju uzlabot laimes izjūtas līmeni, kopumā ir nedaudz nomāktāki (Seligman, et al., 2005). Dati liecina, ka vislielāko labumu no šiem uzdevumiem gūst cilvēki ar zemu pozitīvo afektu vai mēreniem depresijas simptomiem (Lyubomirsky \& Layous, 2013).

Laimes stratēgiju pētījumi norāda arī uz pielikto pụ̄u nozīmi. Vērojams laimes izjūtas pieaugums, ja tiek pieliktas pūles, realizējot eksperimentāli pārbaudìtu laimes stratēǵiju, bet, tai pašā laikā, tas netiek novērots, ja tiek pieliktas pūles realizējot kādu neitrālu aktivitāti (Lyubomirsky, et al., 2011).

Laimes izjūtas paaugstināšanas intervencē nozīme ir arī biežumam un secībai, kādā stratēgijas tiek realizētas. Eksperimentos novērots, ka efektīvāk ir veikt, piemēram, piecas laipnības izpausmes vienas dienas laikā, nevis izkliedēti nedēḷas laikā. Tika secināts, ka tad, ja piecas "laipnības" (durvju atvēršana svešiniekam, palīdzēšana kaimiņam, u. c.) tiek praktizētas vienas dienas laikā, dalībnieku subjektīvā labklājība sešu nedēḷu ilgā pètijuma periodā pieauga, salīdzinot ar kontroles grupu. Šis efekts netika novērots tajā grupā, kur šīs "laipnības" bija jāveic 7 dienu garā periodā. Arī eksperimentā, kurā respondentiem lūdza izteikt pateicības par sev nozīmīgām lietām (par veselỉbu, gimeni, draugiem), laimes izjūtas paaugstināšanos izjuta tie, kas šo uzdevumu veica reizi nedēl̦ā, nevis trīs reizes, salīdzinot ar kontroles grupu. Eksperimentu autori izvirza pieņēmumu, ka pārāk bieža pozitīvo darbību atkārtošana samazina to spēku. Noteikt laimes veicinošo aktivitāšu biežumu ir samērā grūti. Iespējams, ja cilvēki šīs aktivitātes neizjūt kā apgrūtinājumu, vinịi labprātāk praktizē tās biežāk un ilgāk (Lyubomirsky \& Layous, 2013). 
Nozīme ir arī paralēli praktizēto stratēgiju daudzumam. Brīvprātīgajiem, kas laimes intervences ietvaros izvēelējās praktizēt vairāk kā vienu laimes stratēǵiju, bija novērojams lielāks laimes izjūtas pieaugums salīdzinot ar tiem, kas praktizēja tikai vienu stratēgeiju (Parks, Porta, Pierce, Zilca, \& Lyubomirsky, 2012). Citā pētijumā augstāka efektivitāte novērota, praktizējot tieši divas vai četras dažādas laimi veicinošas aktivitātes vienlaicīgi (Schueller \& Parks, 2012). Îstermiņa laimes intervencē, kuras dalībnieki četru nedēḷu garumā izteica pateicības un arī realizēja optimistisku domāšanu, rezultāti uzrādīja, ka jo biežāk tika izmantotas abas stratēgijas, jo nozīmīgāki pozitīi ieguvumi no tām (Sheldon \& Lyubomirsky, 2006). Interesanti, ka pētijumos, kas apskata, kā cilvēki paši sev veicina vai rada laimes izjūtu (reālajā dzìvē) tiek secināts, ka vidēji indivīds veic septiṇas līdz astoṇas darbības savas laimes izjūtas uzlabošanai (Parks et al., 2012). Šie rezultāti liecina, ka potenciālā rutīna un vienveidība būtu jāapsver kā iespējamo šķērsli laimes izjūtas pieaugumam.

Pētijumos ir ticis izvirzīts pieņēmums, ka, jo ilgāka ir intervence, jo lielāks subjektīvās labklājības izjūtas pieaugums. Pētījumu metaanalīze gan parāda, ka lielākā daḷa intervenču ir četru līdz desmit nedēļu garas un, iespējams, tas nav pietiekami ilgs laika posms, lai novērotu iespējamo adaptāciju, saskaṇā ar kuru ieguvums no laimes stratēgijas laika gaitā kritīsies (Sin \& Lyubomirsky, 2009). Ir tikusi prognozēta zvanveida līknes attīstība, kas nozīmē, ka iesākumā, uzsākot intervenci, jo ilgāku laiku tā tiks praktizēta, jo vairāk pieaugs laimes izjūta, bet turpinot realizēt vienu stratēgiju, bez izmaiņām, visdrīzāk, mazināsies interese, un samazināsies piedzīvoto pozitīvo emociju daudzums, salīdzinot ar iepriekšējo laika posmu. Ja indivīds spēj adaptēties pozitīvām izmaiņām, tad visdrīzāk adaptācija būs novērojama arī, praktizējot laimes stratēgijas (Layous \& Lyubomirsky, 2012).

Būtiski atzīmēt, ka pāris nedēḷu garās laimes intervences neprognozē, ka paaugstinās laimes izjūtu uz ilgstošu laika periodu vai arī, ka palīdzēes sasniegt nebeidzamu laimes izjūtu. Daudz lielāka iespēja ir, ka pozitīvo stratēǵiju intervences varētu iemācīt cilvēkiem šîs laimes izjūtu veicinošās tehnikas, kuras vēlāk, pēc nepieciešamības, tiks pielietotas. N̦emot vērā pierādīto efektivitāti, tām būtu vismaz îstermiņā jāpaaugstina laimes izjūtas līmenis (Layous \& Lyubomirsky, 2012). Jāņem vērā arī tas, ka, balstoties uz pētijumiem, pozitīvais efekts (laimes izjutās paaugstināšanās) mēdz būt novērojams nevis uzreiz pēc dalības intervencē, bet pēc nedēlas, mēneša, trim un sešiem mēnešiem. Kā viens no skaidrojumiem ir tāds, ka pētījuma dalībnieki turpina veikt šos uzdevumus arī pēc eksperimenta beigām un tādējādi nostiprinās šo stratēǵiju pozitīvais efekts (Seligman, et al., 2005).

Vēl aizvien turpinās pētījumi par motivāciju, stratēégiju variāciju un to piemērotību indivīdam, tādējādi meklējot viennozīmīgākus secinājumus par stratēgijām un to efektivitāti (Schueller, \& Parks, 2014).

Šî pārskata ietvaros ir apkopotas daudzas, taču ne visas iespējamās stratēégijas, kuras šobrīd tiek pētìtas un pielietotas pozitīvās psiholoğijas pasaulē. Apkopojot informāciju, var secināt, ka laimes veicināšanas stratēgijas darbojas, tomēr tās paredz arī apzinātu paša indivìda iesaisti, piepūli un motivāciju.

N̦emot vērā iepriekš veikto pētijumu rezultātus, šì pētījuma ietvaros tiek izvirzìta hipotēze, ka regulāri praktizēta laimi veicinoša stratēǵija (4 nedēḷas pēc kārtas, katru 
nedēḷu savādāka) eksperimentālajā grupā paaugstinās subjektīvās laimes izjūtas līmeni, bet kontroles grupā, kurā arī veiks subjektīvās laimes izjūtas mērījumus ar 4 nedēẹu starpību, laimes līmeṇa izmaiñas nebūs nozīmīgas. Lai apstiprinātu hipotēzi tika veikts eksperimentāls pētījums balstoties uz iepriekš aprakstìtajiem pētijumiem un eksperimentiem (Lyubomirsky, et al., 2005; Seligman, et al., 2005; Gander, et al., 2013; Schueller, 2011).

\section{Metode}

\section{Pētijuma dalībnieki}

Pētijumā piedalijjās 145 dalībnieki (kontroles grupa $n=75$, eksperimentālā grupa $n=70$ ) vecumā no $18 \mathrm{līdz} 74$ gadiem. Dzimuma proporcija abās grupās bija līdzīgi sadalìta. Kontroles grupā $84 \%$ no dalībniekiem bija sievietes, eksperimentālajā grupā $-86 \%$ sieviešu. Kontroles grupā $5 \%$ dalībnieku ir vidējā vai vidējā profesionālā izglīīiba, $48 \%$ šobrīd iegūst augstāko izglìtību vai ir nepabeigta augstākā izglìtība un $47 \%$ ir augstākā izglìtîba. Eksperimentālajā grupā 4\% dalībnieku ir vidējā vai vidējā profesionālā izglìtība, $44 \%$ šobrīd iegūst augstāko izglìīibu vai ir nepabeigta augstākā izglìtība un 51\% ir augstākā izglìīiba. Rezultāti parāda, ka nepastāv statistiski nozīmīgas atšķirības starp kontroles $(n=75)$ un eksperimentālās grupas $(n=70)$ vecuma $(U=2438,50, p<0,05)$ un izglìīibas $(U=2436,50, p<0,05)$ lìmeṇa rādītājiem.

Eksperimentālā grupa tika veidota, aicinot brīvprātīgi pieteikties laimes izjūtu paaugstinošā intervencē 4 nedẹlu garumā. Aicinājums tika izvietots sociālajā portālā www.facebook.com. Kā kontroles grupa tika izvēlēti psihologijas un pedagogijas studenti no Latvijas Universitātes, kā arī paralēli dati tika vākti ar interneta starpniecību, aicinot piedalīties aptaujā par laimes izjūtu.

\section{Instrumentārijs}

Tika mērīts laimes jeb subjektīvās labklājības līmenis izmantojot Subjektīvās laimes skalu (SLS) (Subjective Happiness Scale, Lyubomirsky, \& Lepper, 1999), kas mēra vispārējo subjektīvo laimes izjūtu. Aptauja sastāv no četriem apgalvojumiem. Pirmajos divos apgalvojumos respondentiem jāraksturo sevi kā vairāk laimīgu vai mazāk laimīgu, gan vispārīgi, gan salīdzinot ar vienaudžiem. Trešajā un ceturtajā apgalvojumā respondentiem piedāvā īsu laimīga un nelaimìga cilvēka aprakstu un lūdz novērtēt, cik lıti tas raksturo pašu respondentu. Apgalvojumu novērtējums piedāvāts Likerta skalā no 1-7 . Jo augstāks rezultāts, jo augstāks subjektīvās laimes izjūtas līmenis. Aptaujas tulkošanu un sākotnējo adaptāciju ( $\alpha=0,83, n=90)$ Latvijā veikusi Žaltkovska (2013).

\section{Procedūra}

Eksperiments tika veikts 2014. gada nogalē un 2015. gada sākumā 2 mēnešu garumā. Sociālajā vietnē $w w w$ facebook.com tika izplatìts aicinājums piedalīties laimes izjūtu paaugstinošā pētijumā - "Laimes programmā". Iespēja pieteikties programmā bija 4 nedẹlu garumā kopš programmas publicēšanas briža, līdz ar to katram respondentam dalība eksperimentā sākās individuāli - kopš pieteikšanās brī̌̌a. Potenciālajam 
dalībniekam (brīvprātīgajam, kurš atsaucās uz aicinājumu un atvēra aptaujas saiti) lūdza aizpildīt speciāli izveidotā interneta aptaujā Subjektīvās laimes skalu, kā arī sniedza ìsu ieskatu par to, kas ir "Laimes programma", kādi ir plānotie uzdevumi un termiņš. Aptaujas beigās, ja dalībnieks izvēlējās piedalīties programmā, tika lūgts norādīt savu e-pasta adresi un turpmākā dalība šajā programmā notika ar e-pasta starpniecību. Katru nedēḷu (4 nedēlas pēc kārtas) dalïbnieks saṇēma aprakstu par veicamo laimes stratēgiju, kuru paveikt nedēḷas laikā (piemēram, “Tavs 1. nedēḷas izaicinājums - izpaust kopā 3 laipnības vai paveikt labus darbus saviem tuviniekiem, draugiem vai paziñām! Piemēram, izteikt kolēgim komplimentu, pagatavot mīlotajam brokastis, novēlēt jauku dienu apsargam un tamlīdzīgi! Dari to apzināti, negaidot neko pretī!”). Katras jaunas nedēlas sākumā dalībniekam lūdza sniegt īsu atgriezenisko saiti par paveikto uzdevumu (aptaujas formā), kā arī informēja par nākamo uzdevumu. 5. nedēlā dalībnieku aicināja sniegt īsu atgriezenisko saiti par iepriekšējās nedēlas uzdevumu un lūdza atkārtoti aizpildīt Subjektīvās laimes skalu. 2015. gada sākumā tika ievākti dati kontroles grupai, aicinot respondentus aizpildìt Subjektīvas laimes skalu un informējot par nepieciešamību veikt atkārtotu mērījumu pēc 4 nedēḷām.

\section{Rezultāti}

Izmantotā instrumentārija - Subjektīvās laimes skalas (SLS) iekšējā saskaņotība tika pārbaudīta ar Kronbaha alfas ticamības rādītāju. Skalas ticamības rādītāji mērījumos ir $\alpha=0,84(N=290)$, kas liecina par augstu iekšèjo saskaņotību. Pirmreizējajā adaptācijā Latvijā tika iegūta Kronbaha alfa $\alpha=0,83(n=90)$, kas arī liecina par augstu saskaņotību (Žaltkovska, 2013). Oriǵinālie aptaujas iekšejjās saskaṇotības rādītāji svārstās robežās no $0,79 \operatorname{līdz} 0,94$ (vidējais $\alpha=0,86)$ un tie tika iegūti dažādās izlasēs $(n=36-622)$ (Lyubomirsky, \& Lepper, 1999).

Eksperimentālais modelis ir 2 (kontroles un eksperimentālā grupa) x 2 (laimes izjūtas mērījumi) un datu analīzei tika pielietota iekšgrupas (repeated measures) ANOVA. Aprakstošās statistikas rādītāji liecina, ka eksperimentālās grupas $(n=70)$ 2. mērījumā ir vērojams augstāks aritmētiskais vidējais laimes izjūtas rādītājs $(M=5,23$, $S D=1,07)$ nekā 1 . mērìjumā $(M=4,91, S D=1,24)$ un arī kontroles grupas $(n=75)$ 2. mērījumā $(M=4,87, S D=1,03)$ ir vērojams augstāks aritmētiskais vidējais laimes izjūtas rādītājs nekā 1 . mērījumā $(M=4,82, S D=1,05)$. (sk.1. tabulu). Dispersiju analīzes aprēķini liecina, ka pastāv statistiski nozīmīga mijiedarbība starp grupu (kontroles un eksperimentālās) un laimes izjūtas mērījumiem $\mathrm{F}(1,143)=6,53, p<0,05$.

\section{1. tabula. Kontroles un eksperimentālās grupas subjektīvās laimes skalas}

1. un 2. mērījumu salīdzināšana

\begin{tabular}{|c|c|c|c|c|}
\hline \multirow{2}{*}{ SLS rādītāji } & \multicolumn{2}{|c|}{$\begin{array}{c}\text { Eksperimentālä grupa } \\
\quad(n=70)\end{array}$} & \multicolumn{2}{|c|}{$\begin{array}{c}\text { Kontroles grupa } \\
(n=75)\end{array}$} \\
\hline & $\mathrm{M}$ & SD & $\mathrm{M}$ & $\mathrm{SD}$ \\
\hline 1. mērījums & 4,91 & 1,24 & 4,82 & 1,05 \\
\hline 2. mērījums & 5,23 & 1,07 & 4,87 & 1,03 \\
\hline
\end{tabular}


Apskatot atsevišḳi atškirīibas eksperimentālajā un kontroles grupā starp laimes izjūtas 1. un 2. mērījuma rezultātiem ar Post - hoc testu (Bonferonni) redzams, ka pastāv statistiski nozīmīgas atšķirības starp eksperimentālās grupas 1. $(M=4,91, S E=0,15)$ un 2. mērijumu $(M=5,23, S E=0,13)$. Tur pretim rezultāti liecina, ka kontroles grupā nepastāv statistiski nozīmīgas atšķirības starp $1 .(M=4,82, S E=1,22)$ un 2. laimes izjūtas mērījumu $(M=4,87, S E=1,20)$. Var secināt, ka eksperimentālās grupas laimes izjūtas līmeṇa pieaugums ir statistiski nozīmīgs, bet kontroles grupā novērotās izmainas nav statistiski nozīmīgas.

Balstoties uz dispersijas analīzē novēroto mijiedarbību un laimes izjūtas vidējajiem rādītājiem, kā arī uz Post - hoc testa (Bonferonni) rezultātiem, var secināt, ka apstiprinās izvirzītā hipotēze, ka regulāri praktizēta laimi veicinoša stratēǵija (4 nedēḷas pēc kārtas, katru nedēlu savādāka) eksperimentālajā grupā paaugstināja subjektīvās laimes izjūtas līmeni, bet kontroles grupā, kurā arī tika veikts subjektīvās laimes izjūtas mērījumus ar 4 nedēlu starpību, laimes līmen̦a izmaiņas nav nozìmīgas.

\section{Diskusija}

Eksperimentālā pētijuma ietvaros tika izvirzìta hipotēze, ka regulāri praktizēta laimi veicinoša stratēgija (4 nedēḷas pēc kārtas, katru nedẹl̦u savādāka) eksperimentālajā grupā paaugstinās subjektīvās laimes izjūtas līmeni, bet kontroles grupā, (kurā arī veiks subjektīvās laimes izjūtas mērījumus ar 4 nedẹlu starpību), laimes līmeņa izmaiņas nebūs nozìmīgas. Eksperimenta rezultāti apstiprina izvirzìto hipotēzi. Pēc respondentu dalības 4 nedẹlu garā programmā, kuras laikā tās dalībnieki realizēja tādas stratēǵijas kā laipnību paušana, labu darbu veikšanu, pateicību paušana un labu notikumu pierakstišanu, eksperimentālajā grupā bija vērojams statistiski nozīmīgs laimes izjūtas līmeṇa pieaugums. Kontroles grupā tādā pašā laika intervālā veiktos laimes izjūtas mērījumos novērotās izmaiņas laimes izjūtas līmenī nebija statistiski nozīmīgas. Abas grupas ir līdzīgas pēc dzimumu sadalījuma un nav būtisku atšķirību vecuma un izglìitibas līmeṇu rādītājos. Balstoties uz rezultātiem var izvirzìt apgalvojumu, ka eksperimentālā iedarbība - dalība laimes programmā - ir paaugstinājusi laimes izjūtas līmeni tās dalībniekiem. Rezultāti saskan arì ar vairumu pētījumu, kurā tika izmantotas līdzīgas stratēǵijas. Piemēram, Ļubomirskas un kolēgu (Lyubomirsky, et al., 2004) pètījumā, kur aicināja studentus realizēt piecus laipnības aktus dienas laikā, reizi nedēlāâ, 6 nedēļu garumā, tika novērots, ka ìstermiņa laimes stratēgijas paaugstina laimes izjūtu. Lìdzīgi kā šajā pētỉjumā, arī L̦ubomirskas un kolēǵu pētỉjumā kontroles grupā tika veikti mērỉjumi ar 6 nedēlu starpību un netika novērots laimes izjūtas pieaugums. Studentu veiktie laipnības akti bija, piemēram, asins ziedošana, izpalīdzēšana skolas darbos, gados vecāko radinieku apciemošana. Laipnības aktu jeb labo darbu realizēšana saistāma ar prosociālu savstarpīguma principu realizēšanu, kā arī iespēju gūt atzinību, novērtējumu un pateicību no citiem (Trivers, 1971). Vēlme būt atzìtam un piederīgam ir uzskatāma par vienu no cilvēka pamatvajadzībām (Baumeister \& Leary, 1995) un caur šo stratēǵiju - laipnībām jeb labajiem darbiem, kura tika izmatota arī šajā eksperimentā, ir iespēja gūt piederības un novērtējuma izjūtu, kas var veicināt laimes izjūtas pieaugumu (Sheldon \& Lyubomirsky, 2004). Līdzīgi tika novērots arī kādā pētījumā bērnu izlasēe, kur pēc laipnības aktu realizēšanas ne tikai pieaugu bērnu laimes izjūta, 
bet arī popularitāte un pozitīvs vienaudžu novērtējums, un šie faktori tiek uzskatīit par saistītiem (Layous, Nelson, Oberle, Schonert-Reichl, \& Lyubomirsky, 2012).

Šì eksperimenta laikā dalībnieki tika aicināti izteikt pateicības. Pateicību paušana ir viena no laimes stratēgijām un Emmons ar kolēgi (Emmons, \& McCullough, 2003) secināja, ka regulāri praktizējot pateicīgu domāšanas veidu, var paaugstināt subjektīvās labklājības līmeni. Pateicība tiek saistīta ar novērtēšanu, pozitīvo dzīves apstākḷu akcentēšanu un pateicību paušana uzskatāma par labu stresa pārvarēšanas stratēgiju un sociālo attiecību stiprinātāju. Var novērot, ka daḷa stratēgiiju pamatā balstās uz pozitīvu savstarpējo attiecību ietekmēšanu, pastiprināšanu vai realizēšanu tiešā vai netiešã veidā, un jau sociālo attiecỉbu veidošana uzskatāma par vienu no dabiski laimīgu cilvēku pazìmēm, tāpat kā prosociāla rīcība un pozitīva domāšana (Fordyce, 1977, 1983; Lyubomirsky, 2001).

Šajā pētījumā realizētā arī tāda stratēǵija kā labo notikumu pierakstīšana, kas bija vienkāršota versija "Trīs labas lietas" stratēgijai. Orğinālajā stratēǵijā nedẹlas garumā, katras dienas beigās būtu jāuzraksta trīs pozitīvas lietas vai notikumi. Šì pētījuma laikā dalībnieki tika aicināti pierakstìt vismaz vienu labu lietu/notikumu katru dienu, septiņu dienu ilgā periodā. Iepriekš veikto pētijumu rezultāti šo stratēǵiju uzrāda kā vienu no efektīvākajām (Seligman, et al., 2005) un šì stratēgija ir vairāk balstīta uz dzīves faktoru pozitīvu novērtēšanu.

Kopumā kā pamatojumu stratēgiju principu darbībai var pieṇemt, ka šīs aktivitātes balstās tikai uz paša cilvēka reālām darbībām, un to rezultāts ir sava dzīves skatijuma maiņa. Pētījumi liecina, ka cilvēki kḷūst laimīgāki pēc stratēgiju realizēšanas tāpēc, ka šìs aktivitātes veicina savas dzīves interpretēšanu pozitīvākā skatījumā, pat ja objektīvie dzīves apstākḷi nav mainījušies (Lyubomirsky, et al., 2011).

Dalība eksperimentā bija brīvprātīga un jāatzīmē, ka brīvprātīgums ir būtisks faktors laimes izjūtas izmain̄ām (Sheldon, \& Lyubomirsky, 2004; Lyubomirsky, et al., 2005). Eksperimenta dalībnieki zināja, ka piedalās "Laimes programmā" un viniiem vajadzētu kḷūt laimīgākiem, tāpēc jāṇem vērā, ka šis fakts arī varēja ietekmēt laimes izjūtas pieaugumu. Iespējams, laimes izjūtas pieaugumu veicinošs faktors bija sociālais atbalsts, vai precīzāk - pozitīvais aicinājums, kuru izteica sociāla portāla lietotāji daloties ar informāciju par "Laimes programmu" ar saviem portāla draugiem. Tika novērots, ka portāla lietotāji komentē šo ierakstu par programmu, piedāvā, iesaka, kā arī paši publiski apstiprina savu dalību. Zināms, ka iesaistī̌sanās pozitīvās darbībās ir daudz efektīvāka, ja indivīds izjūt sociālo atbalstu (Bandura, 1986, kā minēts Lyubomirsky, \& Layous, 2013) vai arī saņem vienaudžu rekomendācijas par šìm aktivitātēm (Lyubomirsky \& Layous, 2013).

Kopumā rezultātu interpretācijā jāṇem vērā tāds ierobežojums, ka pētijuma grupas, balstoties uz demogrāfiskajiem datiem - vecuma un izglìtības lìmeņa rādītājiem neveido reprezentatīvu izlasi, tāpat arī dzimumu sadalījums nav proporcionāls, abās grupās ir sieviešu pārsvars. Eksperimentālā grupa tika veidota, izvietojot aicinājumu sociālajā tìklā un tālāk eksperiments tika realizēts ar e-pasta starpniecību, līdz ar to eksperimentā varēja piedalīties cilvēki, kas izmanto sociālo portālu www.facebook.com un e-pastu, savukārt daḷa kontroles grupa tika veidota no pedagoǵijas un psihologijas studentiem un dạ̦a datu arī tika ievākti izmantojot sociālo portālu www.facebook.com, 
un kopumā tas var būt uzskatāms par izlases ierobežojumu. Tāpat iespēja kontrolēt dalībniekus ir uzskatāma par vienu no pētījuma vājajām pusēm. Lai arī dalībnieki precīzi, reizi nedēḷā, saṇēma stratēǵijas aprakstu un īsu aptauju, kurā sniegt atgriezenisko saiti par iepriekšējās nedēḷas uzdevumiem, nav iespējams būt drošiem, ka stratēgija tika realizēta korekti, apzināti un atbilstoši tam, kā to vajadzētu darìt. Piedāvājot stratēǵijas tika dotas arī idejas un varianti, kā to realizēt, kā piemēram (teksts no e-pasta dalībniekiem): “Tavs 1. nedēḷas izaicinājums - izpaust kopā 3 laipnības vai paveikt labus darbus saviem tuviniekiem, draugiem vai pazin̄ām! Piemēram, izteikt kolēgim komplimentu, pagatavot mịlotajam brokastis, novēlēt jauku dienu apsargam un tamlīdzīgi! Dari to apzināti, negaidot neko pretī!". Piemēri tika piedāvāti tādi, kas parāda, ka aktivitātes var būt vienkāršas, ikdienā viegli realizējamas. Tomēr to, cik kvalitatīvi tās tika izpildītas, kontrolēt nebija iespējams. Jebkurā gadījumā, laiks, ko cilvēks veltīja stratēǵijas pierakstīšanai atgriezeniskās saites aptaujā, lika apzināti pievērst uzmanību pozitīvām, patîkamām lietām, notikumiem un emocijām, tādējādi novērtējot piedzivvoto. Pētījumi liecina, ka pozitīvo notikumu novērtēšana un pozitīvā akcentēšana mazina pierašanu pie notikumiem, tie nezaudē savu emocionālo nozīmi un netiek uztverti kā pašsaprotami (Emmons, 2008, kā minēts Schueller, 2011). Citu pētījumi rezultāti parāda, ka laimes izjūta pieaug, vienkārši uzskaitot savus labos darbus vai laipnības izpausmes reizi nedẹlā (Otake, et al., 2006). Iespējams, pat tikai process, kad reizi nedēḷā apzinās pozitīvas lietas un pieraksta tās, ir uzskatāms par pietiekami efektīvu, lai paaugstinātos laimes izjūta.

Pat, ja šajā gadījumā nav skaidri nodalāms, kas tieši ir tas faktors, kas paaugstināja laimes izjūtas līmeni - stratēǵijas realizācija vai apzināta pierakstīšana (neatkarīgi no tā vai uzdevumu veica apzināti vai tikai atsauca atmiṇā nedēlas laikā piedzìvoto) vai abi faktori kopā, jebkurā gadījumā, eksperimenta rezultāti apliecina, ka dalība laimes programmā nozīmīgi paaugstināja laimes izjūtas līmeni.

Tika saṇemtas atsauksmes no dalībniekiem, kurās izteica pateicību par iespēju piedalīties programmā, norādīja, ka uzdevumi bija saprotami un viegli realizējama. Daži respondenti akcentēja, ka varēja "novērot sevi no malas" un saprast, "cik daudz labas lietas un darbus ikdienā” veic vai neveic. Daži stratēǵiju realizēšanu uztvēra kā izaicinājumu. Kāda dalībniece izteica secinājumu "Tik viegli būt laimīgam un tik grūti iemācīties l̦aut sev būt laimīgam!’. Kāda cita dalījās, ka iepriekš sevi nav uzskatījusi par ìpaši laimīgu cilvēku, bet katru nedẹlı domājot par labo, novēroja, ka notiek daudz pozitīvu lietu un vienkārši nemāk uz tām paskatīties no malas. Šie dalībnieku sniegtie komentāri norāda, ka labo darbu apzināšanās un sevis vērošana no malas, iespējams, ir tas, uz ko šĩs stratēǵijas darbojas.

Saṇemot atgriezeniskās saites par paveiktajiem labajiem darbiem, var novērot, ka bieži tie izpaudās kā mazas laipnības - uzmundrinājumi ǵimenes locekḷiem, draugiem un kolēgiem, labas dienas vēlējumi apkalpojošajam personālam, komplimenti, rūpes par ǵimenes locekḷiem. Kā labos notikumus respondenti minēja draugu satikšanu, garšīgu èdienu, ǵimenes notikumus (tikšanās, kopīga brīvā laika pavadīšana), veiksmīgi pabeigtu mācību semestri, iespēja izgulēties, filmu skatīšanos un grāmatu lasīšanu, dāvanu iegādi un saṇemšanu. Pateicības tika izteiktas par atbalstu no kolēgim darbā, par otra cilvēka sniegtajām rūpēm, atbalstu, sapratni. Tāpat par tādām sadzīviskām lietām 
kā pagatavotu èdienu un mājas soḷa paveikšanu. Rakstot atgriezenisko saiti par šīm stratēóijām, dalībnieks visdrīzāk secina, ka patiesībā ir daudz labu lietu, notikumu, kā arī pats respondents dara labu, tikai nepievērš tam ikdienā apzinātu uzmanību. Iespējams, arī novēro, ka varētu darìt vairāk, un, ja ir motivācija un vēlme, tas tiek uztverts kā izaicinājums un stratēǵijas tiek realizētas. Tas arī saskan ar iepriekš minēto, ka pozitīvo dzīves notikumu apzināšanās un uzmanības pievēršana pati par sevi ir efektīva stratēgija laimes izjūtas paaugstināšanai (Otake, et al., 2006; Emmons, 2008, kā minēts Schueller, 2011). Tā kā laimes izjūtu paaugstinošās stratēgijas pamatā balstās uz divu faktoru kombināciju - palīdzēt cilvēkiem pozitīvāk apskatìt un novērtēt savus dzīves apstākḷus, kā arī dot iespēju pieredzēt vairāk pozitīvas un mazāk negatīvas emocijas (Schueller \& Parks, 2014), tad iegūtie rezultāti - laimes izjūtas līmeņa pieaugums eksperimentālajā grupā atspoguḷo stratēgiju efektivitāti, balstoties uz principiem - novērtēt un piedzīvot. Visas izmantotās stratēgijas un atgriezenisko saišu rakstīšana ietver šos abus faktorus, un tieši novērtēšana, kas notiek, apzināti pierakstot piedzīvoto, atkārtoti parādās kā iespējams viens no būtiskākajiem aspektiem laimes izjūtas pieaugumam. Tas arī rosina tālāk pētìt, kā tieši stratēǵijas darbojas, kura laimes intervences daḷa ir tā iedarbīgākā un efektīvākā - pašas stratēgijas realizēšana vai piedzìvotā apzināšanās. Iespējams, tas ir komplicēts process, kura iedarbība katram ir l̦oti individuāla. Kādam laimes izjūta paaugstinās apzināti, izdomājot un realizējot stratēgiju, citam, vienkārši atskatoties uz, piemēram, nedēlas laikā piedzīvoto un novērtējot to. To turpmāk varētu izzināt un realizēt eksperimentālā pētỉjumā, kur vienai no grupām būtu jāveic stratēǵijas un jāpieraksta tās, bet otrai - tikai reizi nedēḷa jāpieraksta, piemēram, paveiktie labi darbi, izteiktās pateicíbas un labie notikumi, neizvirzot mērḳi kaut ko mainīt savās ikdienas darbībās.

Baltoties uz eksperimenta pozitīvajiem rezultātiem, izmantotās stratēgijas var pielietot arī dažādās grupās, piemēram, veidot šādas ìstermiṇa laimes programmas izglìtības iestādēs, mudinot skolēnus un studentus konkrētā laika posmā realizēt šîs vienkāršās stratēgíijas, kā arī izveidot sistēmu, kādā dalībnieki sniedz atgriezenisko saiti. Piemēram, viens no atgriezeniskās saites sniegšanas veidiem varētu būt klasē izveidota "laimes veicināšanas kaste" vai, piemēram, virtuāli - kopīga, visiem dalībniekiem pieejama platforma, kurā tiek ierakstìts paveiktais. Individuāli laimes izjūtu veicinošās stratēgijas var tik veiktas psihologa, psihoterapeita vai citas atbalsta personas vadībā. Šì eksperimenta fokuss bija uz grupu, kuras dalībnieki saṇēma vienādus e-pastus, bez papildus, individuālas pieejas katram, bet, kā redzams, arī šādi realizēta pieeja (strukturēta, vadìta, bet ne individualizēta) ir pietiekami efektīva.

N̦emot vērā šobrīd veikto pētījumu apjomu un iegūtos rezultātus par laimes stratēǵiju reālo efektivitāti (Sin \& Lyubomirsky, 2009), var pieṇemt, ka tās visdrīzāk darbojas. Šì eksperimentālā pētījuma ietvaros novērojams, ka dalība laimes programmā, kurā tika pielietotas stratēgijas, balstītas uz iepriekš veiktiem pētījumiem (Seligman, et al., 2005; Lyubomirsky, et al., 2005; Otake, et al., 2006; Lyubomirsky, et al., 2011), ir bijusi efektīva - laimes izjūtas līmeni paaugstinoša. It ippaši uzsverot to, ka kontroles grupā izmaiṇas netika novērotas, lai arī sākuma stāvoklis - laimes līmenis - bija uzskatāms par līdzīgu abās grupās. 


\section{Izmantotā literatūra}

Baumeister, R. F., \& Leary, M. R. (1995) The Need to Belong: Desire for Interpersonal Attachments as a Fundamental Human Motivation. Psychological Bulletin, 117(3), 497-529.

Bryant, F. B. (1989). A four-factor model of perceived control: Avoiding, coping, obtaining, and savoring. Journal of Personality, 57, 773-797.

Bryant, F. B. (2003). Savoring beliefs inventory (SBI): A scale for measuring beliefs about savoring. Journal of Mental Health, 12, 175-196.

Boehm, J. K., Lyubomirsky, S., Sheldon, K. M. (2011). A Longitudinal Experimental Study Comparing The Effectiveness Of Happiness-Enhancing Strategies In Anglo Americans and Asian Americans. Cognition \& Emotion, 25, 1263-1272.

Costa, P. T., \& McCrae, R. R. (1980). Influence Of Extraversion And Neuroticism On Subjective Wellbeing: Happy And Unhappy People. Journal of Personality and Social Psychology, 38, 668-678.

DeNeve, K. M., \& Cooper, H. (1998). The happy personality: A metaanalysis of 137 personality traits and subjective well-being. Psychological Bulletin, 124, 197-229.

Diener, E. (1984). Subjective Well-Being. Psychological Bulletin, 95, 542-575.

Dunn, E. W., Aknin, L. B., \& Norton, M. I. (2008). Spending money on others promotes happiness. Science, 319, 1687-1688.

Diener, E., \& Lucas, R. E. (1999). Personality, and subjective well-being. In D. Kahneman, E. Diener, \& N. Schwarz (Eds.). Well-being: The foundations of hedonic psychology (213-229). New York: Russell Sage Foundation.

Emmons, R. A., \& McCullough, M. E. (2003). Counting Blessings Versus Burdens: An Experimental Investigation Of Gratitude and Subjective Well-Being In Daily Life. Journal of Personality and Social Psychology, 84, 377-389.

Fredrickson, L. B., Cohn, M. A., Coffey, K. A., Pek, J., \& Finkel, S. M. (2008). Open Hearts Build Lives: Positive Emotions, Induced Through Loving-Kindness Meditation, Build Consequential Personal Resources. Journal of Personality and Social Psychology, 95(5), 1045-1062.

Fordyce, M. W. (1977). Development of a program to increase happiness. Journal of Counseling Psychology, 24, 511-521.

Fordyce, M. W. (1983). A program to increase happiness: Further studies. Journal of Counseling Psychology, 30, 483-498.

Gander, F., Proyer, R. T., Ruch, \& W., Wyss, T. (2013). Strength-Based Positive Interventions: Further Evidence for Their Potential in Enhancing Well-Being and Alleviating Depression. Journal of Happiness Studies, 14, 1241-1259.

Hurley, D. B., \& Kwon, P. (2012). Results of a Study to Increase Savoring the Moment: Differential Impact on Positive and Negative Outcomes. Journal of Happiness Studies, 13, 579-588.

King, L. A. (2001). The health benefits of writing about life goals. Personality and Social Psychology Bulletin, 27, 798-807.

Kurtz, J. L., \& Lyubomirsky, S. (2013). Using mindful photography to increase positive emotions and appreciation. In J. Froh \& A. C. Parks (Eds.), Activities for teaching positive psychology: A guide for instructors (pp. 28-33). Washington, DC: American Psychological Association.

Layous, K., Lee, H. C., Choi, I., \& Lyubomirsky, S. (2013). Culture Matters When Designing a Successful Happiness-Increasing Activity. A Comparison of the United States and South Korea. Journal of Cross-Cultural Psychology, 44(8), 1294-1303. 
Layous, K., \& Lyubomirsky, S. (2012). The how, who, what, when, and why of happiness: Mechanisms underlying the success of positive interventions. To appear in J. Gruber \& J. Moskowitz (Eds.), Light and dark side of positive emotion. Oxford: Oxford University Press.

Layous, K., Nelson, S. K., \& Lyubomirsky, S. (2012). What is the optimal way to deliver a positive activity intervention? The case of writing about one's best possible selves. Journal of Happiness Studies, 14, 635-654.

Layous, K., Nelson, S. K., Oberle, E., Schonert-Reichl, K. A., \& Lyubomirsky, S. (2012). Kidness Counts: Promoting Prosocial Behavior in Preadolescents Boosts Peer Acceptance and WellBeing. PLoS ONE 7(12): e51380. doi:10.1371/journal/pone.0051380.

Lyubomirsky, S., \& Dickerhoof, R. (2011). A construal approach to increasing happiness. In Maddux, E., \& Tangney, J. P.(Eds.), Social psychological foundations of clinical psychology, (pp.229-240). New York: The Guilford Press.

Lyubomirsky, S., Dickerhoof, R., Boehm, J. K., \& Sheldon, K. M. (2011). Becoming happier takes both a will and a proper way: An experimental longitudinal intervention to boost well-being. Emotion, 11(2), 391-402.

Lyubomirsky, S., King, L., \& Diener, E. (2005). The benefits of frequent positive affect: Does happiness lead to success? Psychological Bulletin, 131(6), 803-855.

Lyubomirsky, S., Layous, K. (2013). How Do Simple Positive Activities Increase Well-Being? Science, 22(1), 57-62.

Lyubomirsky, S., \& Lepper, H. S. (1999). A measure of subjective happiness: Preliminary reliability and construct validation. Social Indicators Research, 46, 137-155.

Lyubomirsky, S., Sheldon, K. M., \& Schkade, D. (2005). Pursuing happiness: The architecture of sustainable change. Review of General Psychology, 9(2), 111-131.

Lyubomirsky, S., Sousa, L., \& Dickerhoof, R. (2006). The costs and benefits of writing, talking, and thinking about life's triumphs and defeats. Journal of Personality and Social Psychology, 90 (4), 692-708.

Lyubomirsky, S. (2001). Why are some people happier than others? American Psychologist, 56, 239-249.

MacLeod, A. K., Coates, E., \& Hetherton, J. (2008). Increasing well-being through teaching goal-setting and planning skills: Results of a brief intervention. Journal of Happiness Studies, 9, 185-196.

Myers, D. G., \& Diener, E. (1995). Who is happy? Psychological Science, 6, 10-19.

Nes, R. B., Røysamb, E., Tambs, K., Harris, J. R., \& Reichborn-Kjennerud,T. (2006). Subjective well-being: Genetic and environmental contributions to stability and change. Psychological Medicine, 36, 1033-1042.

Otake, K., Shimai, S., Tanaka-Matsumi, J., Otsui, K., \& Fredrickson, B. L.(2006). Happy people become happier through kidness. A couenting kindnesses intervention. Journal of Hapiness Studies, 7, 361-375.

Parks, A. C., Della Porta, M. D, Pierce, R. S., Zilca, R., Lyubomirsky, S. (2012). Pursuing happiness in everyday life: The characteristics and behaviors of online happiness seekers. Emotion, 12(6), $1222-1234$.

Schueller, S. (2011). Creating a Recommendation Framework for Positive Psychology Exercises: The Netflix Model of Positive Psychology. Publicly accessible Penn Dissertations, 392, 1-91. 
Schueller, S. M. (2012). Personality fit and positive interventions: Extraverted and introverted individuals benefit from different happiness increasing strategies. Psychology, 3, 12a, 1166-1173.

Schueller, S. M., \& Parks, A. C. (2012). Disseminating self-help: Positive psychology exercises in an online trial. Journal of Medical Internet Research, 14, e63.

Schueller, S. M., \& Parks, A. C. (2014). The Science of Self-Help Translating Positive Psychology Research Into Increased Individual Happiness. European Psychologist, 19(2), 145-155.

Seligman, M. E. P., Tracy, A. S., Park, N., \& Peterson, C. (2005). Positive Psychology Progress. Empirical Validation of Interventions, American Psychologist, 60(5), 410-421.

Seligman, M. E. P., Rashid, T., \& Parks, A. C. (2006). Positive psychotherapy. American Psychologist, 61, 774-788.

Sheldon, K. M., \& Lyubomirsky, S. (2004). Achieving sustainable new happiness: Prospects, practices, and prescriptions. In A. Linley \& S. Joseph (Eds.), Positive psychology in practice (pp. 127-145). Hoboken, NJ: John Wiley \& Sons.

Sheldon, K. M., \& Lyubomirsky, S. (2006). How to increase and sustain positive emotion: The effects of expressing gratitude and visualizing best possible selves. Journal of Positive Psychology, 1, 73-82.

Sin, N. L., \& Lyubomirsky, S. (2009). Enhancing well-being and alleviating depressive symptoms with positive psychology interventions: A practice-friendly meta-analysis. Journal of Clinical Psychology, 65(5), 467-487.

Suh, E. M., \& Oishi, S. (2002). Subjective well-being across cultures. In W. J. Lonner, D. L. Dinnel, S. A. Hayes, \& D. N. Sattler (Eds.), Online Readings in Psychology and Culture. Retrieved February, 20, 2014, from http://www.wwu.edu/culture/Suh_Oishi.htm.

Trivers, R. (1971). The evolution of reciprocal altruism. Quarterly Review of Biology, 46, 35-57.

Watkins, P. C., Grimm, D. L., \& Kolts, R. (2004). Counting Your Blessings: Positive Memories Among Grateful Persons. Current Psychology: Developmental, Learning, Personality, Social, 23 (1), 52-67.

Weiss, A., Bates, T., \& Luciano, M.(2008). Happiness is a personal(ity) thing: the genetics of personality and well-being in a representative sample. Psychological Science, 19 (3), 205-210.

Žaltkovska, K. (2013). Subjektīvo labklājību jeb laimes izjūtu paaugstinošās stratēgijas. Nepublicēts LU kursa darbs II. 


\title{
Nepatieso pārliecību izpratne un spēja apvaldìt reakcijas 3-5 gadus veciem bērniem
}

\author{
Kristiāna Kalniņa un Anika Miltuze ${ }^{1}$
}

Latvijas Universitāte

\begin{abstract}
Abstrakts
Pētījuma mērḳis bija izpētìt, kādas sakarības pastāv starp prāta teorijas spējām un bērna temperamentu - tā dimensiju Spēja apvaldìt reakcijas $-3-5$ gadus veciem bērniem $(n=52)$. Prāta teorijas spēju izpētē tika izmantoti nepatieso pārliecību uzdevumi (Wimmer \& Perner, 1983, Perner, Leekam \& Wimmer, 1987, Perner, Ruffman \& Leekam, 1994, adaptācija latviešu valodā Rodzeviča, 2011, taču tulkojumā šì pētījuma gaitā veikti uzlabojumi): "Negaidītās pārmaiṇas", "Maldināšanas stāsts", "Negaidītā satura uzdevums"; reakciju apvaldīšanas kontroles uzdevumi: "Piesitieni” (Diamond \& Taylor, 1996; latviski savā promocijas darbā tulkojusi Krone, 2013), "Diena - Nakts" (Gerstadt, Hong \& Diamond, 1994, latviski tulkojusi Krone). Pètījuma rezultāti liecina, ka pastāv statistiski nozīmīgas sakarības starp bērnu vecumu, nepatieso pārliecību izpratni un spēju apvaldìt reakcijas. Prāta teorijas spējas 3-5 gadu vecumā nepatieso pārliecību izpratnes uzdevuma Maldināšanas stāsts gadījumā prognozē bērnu vecums, kā arī verbālo reakciju apvaldī̌̌anas spējas.
\end{abstract}

Atslēgas vārdi: prāta teorija, temperaments, spēja apvaldìt reakcijas.

\section{Preschool Children's (3-5 years) Inhibitory Control and False Belief Understanding \\ Kristiāna Kalniņa and Anika Miltuze \\ University of Latvia}

\begin{abstract}
The goal of this research was to investigate the associations between inhibitory control and theory of mind ability in preschool children $(N=52)$, ages $3-5$. Children were asked to participate in the False Belief Task (Wimmer \& Perner, 1983, Perner, Leekam \& Wimmer, 1987, Perner, Ruffman \& Leekam, 1994, adaptation in Latvia, Rodzeviča, 2011, Latvian translation improvement as a part of this research), Unexpected Change Task, Misinformation Story, and Smarties Task. Children were asked to participate in the following inhibitory control tasks: Tapping Task (Diamond \& Taylor, 1996), and Day and Night (Gerstadt, Hong \& Diamond, 1994) (initial adaptation in Latvia by Krone, 2013). Results showed corellation between children's age, false belief and inhibitory control ratings. Age and better inhibitory control of verbal reactions were predictors of higher ratings for the false belief task Misinformation Story, indicating more advanced theory of mind abilities.
\end{abstract}

Keywords: temperament, inhibitory control, theory of mind, age.

1 Corresponding author: Anika Miltuze, University of Latvia, Jurmalas gatve 76, Riga LV-1083, Latvia. Email: anika.miltuze@lu.lv 
3 - 5 gadu vecumā bērniem izteikti attīstās temperamenta dimensija apzināta reakciju kontrole, tostarp tās apakšdimensija - spēja apvaldīt reakcijas -, kā arī prāta teorijas spējas jeb nepatieso pārliecību izpratne. Vairākas no temperamenta dimensijām ir loti būtiskas prāta teorijas attīstībā, savukārt prāta teorijas un temperamenta mijiedarbība varētu būt nozīmīga bērna turpmākajā sociālajā, emocionālajā un kognitīvajā attīstībā. Lai gan mūsdienās tiek runāts par jau salīdzinoši agrīnu bērna spēju izprast citu cilvēku nolūkus un vēlmes, tomēr ir atsevišḳi nepatieso pārliecību uzdevumi, kurus bērni nespēj paveikt līdz aptuveni četru gadu vecumam.

Prāta teorija ir spēja izprast citu cilvēku garīgo stāvokli - uzskatus, vēlmes, emocijas un nodomus (Siegal \& Varley, 2002; Wellman, Cross, \& Watson, 2001, kā minēts Sundquist \& Ronnberg, 2010). Ši kompleksā prasme ir integrēta bērna sociālajā kompetencē un sociālajā izziņā un strauji attīstās pirmsskolas vecumā - bērns apgūst izpratni, ka citas personas var domāt, justies un rīkoties atškirīgi no tā, kā domā, jūtas un rīkojas viņš pats, turklāt cits indivīds savās pārliecībās var kḷūìities. Ja trīs gadu vecumā lielākā daḷa bērnu, saskaņā ar nepatieso pārliecību testa mērijumiem (false believe task), vēl nespēj saprast, ka citam cilvēkam var būt atšķirīga pārliecíba par apgalvojumu, kas viņam pašam zināms kā nepatiess, tad jau četru un piecu gadu vecumā lielākā daḷa bērnu to spēj saprast (Wellman et al., 2001, kā minēts Sundquist et al., 2010). Daži pētnieki uzskata, ka viena no prāta teorijas nozìmēm ir spēja prognozēt cita indivīda rīcību jeb instrumentālais prāta teorijas mērḳis, otra nozīme - spēja novērtēt citas personas emocionālos stāvokḷus jeb afektīvais mērḳis, turklāt no prāta teorijas attīstās empātija (Drubach, 2008). Savukārt citi pētnieki pauduši, ka tie procesi, kuri veido empātiju (kognitīvā kontrole jeb spēja apvaldìt automātiskās reakcijas uz stimulu, kā arī perspektīvas ieņemšana jeb spēja iztēloties notiekošo un izjust otra cilvēka jūtas no cita skatupunkta) attīstās neatkarīgi no prāta teorijas, un tikai vēlāk abas - prāta teorija un empātija - darbojas vienoti (Gerstad, Hong, \& Diamond, 1994). Sāra Songhoriana norāda, ka empātija un prāta teorija ir divi dažādi, taču savstarpēji kooperatīvi mehānismi, taču empātija ir ontogenētiski un filogenenētiski primitīvāks mehānisms, atšķirībā no prāta teorijas, kura ir vairāk saistīta ar augstākiem kognitīvajiem procesiem (Songhorian, 2013). Vēl citi zinātnieki izpētījuši - ja ap divu gadu vecumu bērns jau lieto emociju vārdus, tad daudz sarežgìīāka kognitīvā izpratne par citu jūtām netiek novērota pirms četru gadu vecuma (Baron-Cohen, Tager-Flusberg, \& Cohen, 2000).

Heincs Vimmers un Josifs Perners (Hainz Wimmer \& Josif Perner) izveidojuši nepatieso pārliecỉbu uzdevumus, ar kuriem tika noteikts, vai bērns izprot, ka cita indivīda pārliecības un zināšanas var atšķirties no viṇa paša pārliecībām, un, vai bērns izprot, ka cits indivìds savās pārliecỉbās var kḷūdīties (Wimmer \& Perner, 1983). Viens no uzdevumiem ir "Negaidītās pārmaiņas", kurā bērniem ar lellēm, kas imitē cilvēku tēlus, tiek demonstrēts, kā viens no varoṇiem ievieto objektu kādā vietā, bet kamēr pats devies prom, otrs stāsta varonis to pārvieto citā vietā. Tad bērnam tiek jautāts par stāsta pirmo varoni, kurš devies prom - kā viņš domā, kur novietots objekts, un kur to meklēs pèc atgriešanās. Eksperimentā ar 3-9 gadus veciem bērniem tika secināts, ka uzdevumā pareizas atbildes nevarēja sniegt neviens no 3-4 gadus veciem bērniem, no 4-6 gadus veciem bērniem pareizi atbildēja 57\%, un no bērniem, kuri vecāki par 6 gadiem, pareizi atbildēja 86\%. Otrs uzdevums ir "Maldināšanas stāsts", kurā tiek demonstrēts iepriekšminētā stāsta turpinājums - stāsta varonis, kurš bija devies 
prom, nejauši kḷūdoties, pastāsta trešajam stāsta varonim, ka objekts atrodas sākumā novietotajā vietā, lai gan patiesībā tur netrodas. Bērnam tiek jautāts par stāsta trešo varoni - jaunpienācēju - vai viņš zina -, vai arī nezina, kur novietots objekts, kur trešais varonis uzskata, kur ir objekts un kur viņš to meklēs pēc atgriešanās. Eksperimentā tika secināts, ka pirmā varoṇa stāstìto kā nepatiesību atzina tikai 28\% no 4-6 gadus veciem bērniem, kamēr bērnu grupā vecumā no 6 gadiem pirmā varoṇa stāstìto kā nepatiesu atzina $94 \%$ bērnu. Tas norāda, ka 3-4 gadu vecumā bērni lielākoties nespēj izprast nepatieso pārliecību uzdevumus, bet 4-6 gadu vecumā lielākā daļa bērnu to jau spēj, un šì spēja pieaug, palielinoties bērnu vecumam.

Tomēr daļa pētnieku norāda, ka bērni jau agrāk - pat 18 mēnešu vecumā - spēj veikt cita veida uzdevumus, kas atspogulo bērnu izpratni, ka cita cilvēka vēlmes var būt atškirīgas no viṇa paša vēlmēm (Repacholi \& Gopnik, 1997). Elisona Gopņika (Alison Gopnik, 1997) to pētija savā eksperimentā ar krekeriem un brokoḷiem, pārliecinoties, ka bērni labprātāk izvēlas ēst krekerus, nevis brokoḷus, un tad eksperimenta vadítājs bērniem nodemonstrēja, ka pašam l̦oti garšo brokol̦i, un pēc brī̌̌a palūdza bērnam "pasniegt vienu", nenorādot konkrēti uz brokoḷiem vai krekeriem. Bērni izvēlējās eksperimenta vadītājam iedot tieši brokol̦a gabaliņu, par ko eksperimenta vaditāiss iepriekš bija izrādījis sajūsmu, nevis krekeri, kas garšo pašam bērnam. Līdz ar to tika parādīts, ka mazbērna vecumposmam raksturīgais egocentrisms tomer neattiecas uz bērna spēju izprast cita cilvēka vēlmes. Gopņika to skaidro ar bērnu smadzeṇu strukturālajām atšķirībām no pieaugušo smadzenēm, kas palīdz bērniem labāk apgūt jaunas zināšnas un prasmes - bērni vairāk tendēti uz izpēti, lietu dabu izzināšanu, kamēr pieaugušajiem šie izpētes ieradumi tiek aizstāti ar mazāk elastīgu domāšanas stilu, bet maziem bērniem līdz ar to veidojas daudz vairāk neironu savienojumu, daudz vairāk jaunu sinapšu nekā pieaugušajiem.

Pētijumos tiek akcentēta arī ideja par prāta teorijas attīstības saistību ar indivīda tendenci iesaistīties agresīvos aktos vai paust agresiju. Ir pētnieki, kas apgalvo, ka nepieciešama sarežǵìta prāta teorija, lai iesaistītos izsmalcinātos agresijas aktos (Sutton, Smith, \& Swettenham, 1999, kā minēts Swit \& McMaugh, 2012). Tomēr prāta teorijas loma, skaidrojot agresīvu uzvedību, tiek apšaubìta, jo daži pētījumi rāda nozīmīgu sakarību starp prāta teoriju un naidīgu uzvedību (Björkqvist, Osterman, \& Kaukiainen, 2000, kā minēts Swit \& McMaugh, 2012), bet citi - par būtisku sakarību starp prāta teoriju un prosociālu uzvedību jeb uzvedību, kas vērsta uz to, lai veicinātu sociālo pieņemšanu un draudzỉbu (Watson, Nixon, Wilson, \& Capage, 1999, kā minēts Swit \& McMaugh, 2012). Agresijas un prāta teorijas saistības tiek skaidrotas ar to, ka iespējams, bērni, kuriem jau ir tendence rīkoties agresīvi un kuriem agrāk attīstījušās prāta teorijas spējas, var šīs spējas vairāk izmantot agresijas aktos (Wellman \& Liu, 2004). Nepietiekamas prāta teorijas spējas un līdz ar to nespēja prognozēt cita cilvēka rīcību ir raksturīga pazìme bērniem ar autiskā spektra traucējumiem(Gliga \& Senju et al., 2014). Pie autiskā spektra traucējumiem vislabāk novērojama traucēta prāta teorijas mehānisma attīstība - šim traucējumam ir dramatiskas sekas attiecībā uz sociālo mācīšanos (Leslie et al., 2004). Savukārt fantāzija pirmsskolas vecumā prognozē labākas prāta teorijas spējas (Dore \& Lillard, 2015), lai gan pagaidām līdz galam nav skaidri mehānismi, kā tieši šì mijiedarbība notiek. Viens no skaidrojumiem - bērnam iztēlojoties, piemēram, ka iedomu draugs sēž ar viṇu kopā pie galda un komunicē, bērns 
praktizē savas spējas izprast, kā varētu domāt cits cilvēks, un tā tiek vingrināta bērna nepatieso pārliecību izpratne.

Vairākos pētījumos secināts, ka prāta teorijas attīstībā liela nozīme varētu būt individuālajām temperamenta atškịīibām. Saskaṇā ar Mērijas Klevjordas Rotbartas (Mary Klejword Rothbart) un kolēgu neirobiologiskās attīstības teoriju, temperaments ir bioloǵiski noteiktas individuālās atškiriribas nervu sistēmas darbībā stresa reakcijās un stresa pārvarēšanas stratēgijās, un šīs atšḳirības izpaužas divos lielos uzvedības aspektos - reaktivitātē jeb emocionālajās, motorajās un uzmanības reakcijās un pašregulācijā jeb procesos, kas regulē reaktivitāti (Rothbart \& Derryberry, 1981, kā minēts Rothbart, 2007; Rueda \& Rothbart, 2009; Rothbart, 2011). Šīs atšķirības ir bioloǵiski noteiktas, taču tās ietekmē arī indivīda pieredze, ar kuru kopā temperaments veido indivīda personību (Rothbart, 2007). Reaktivitātes jēdziens attiecas uz bioloǵisko uzbudinājumu neiroendokrīnajā, veǵetatīvajā un emocionālajā sistēmā, kā arī uz indivīda uzvedību. Individuālās atšķirības reaktivitātē raksturo reaktivitātes slieksnis, reakcijas latentums, konkrētās reakcijas intensitāte, pieaugums un atjaunošanās laikā. Savukārt pašregulācijas dimensija - apzināta reakciju kontrole -, gluži pretēji, attiecas uz procesiem, kuri palielina, samazina, saglabā un pārstrukturē reaktivitātes paternus, tos paredzot vai koriǵējot (Rothbart \& Derryberry, 1981). Gan reaktīvā, gan pašregulācijas uzvedība ir saistīta ar neirobiologiskajiem procesiem. Reaktivitāte nozīmē organisma uzvedības un fiziologisiskās sistēmas uzbudināmību un atbilstošas reakcijas ierosināšanu, bet pašregulācija nozīmē neirālo un uzvedības procesu funkcionēšanu, lai kontrolētu reaktivitāti (Rothbart \& Derryberry, 1981, kā minēts Rothbart \& Rueda, 2005).

Rotbarta un kolēgi pētījumos ir noteikuši trīs temperamenta dimensijas: reaktivitāti (surgency), negatīvu emocionalitāti (negative affect), apzinātu reakciju kontroli (Rothbart, 2011). Reaktivitāte raksturo to, kāda ir automātiskā atbildes reakcija uz izmaiṇām iekšèjā vai ārējā vidē, savukārt negatīvā emocionalitāte raksturo to, cik emocionāli jūtīgi bērns automātiski reaǵē uz iekšējās un ārējās vides stimuliem. Apzināta reakciju kontrole nozīmē spēju kavēt dominējošo atbildes reakciju par labu nākamajai, mazāk dominējošajai atbildes reakcijai jeb spēja vajadzīgā brīdī apslāpēt automātisko atbildes reakciju un reaǵēt atbilstoši (Rothbart \& Bates, 2006, kā minēts Zentner \& Bates, 2008, Rothbart, 2011). Apzināta reakciju kontrole tiek uzskatìta par temperamenta īpašo dimensiju - tās iezīmes parādās bērnam ap gada vecumu, bet kḷūst spēcīgākas starp otro un trešo dzīves gadu, kā arī turpina attīstīties līdz ar bērna nervu sistēmas un galvas smadzeṇu nobriešanu. Apzinātas reakciju kontroles individuālās atšk ķirības saistītas ar vadības funkcijām, kas lokalizētas galvas smadzeņu pieres daivā un ir saistītas ar uzmanības vadības sistēmu (executive attention), konkrētiem specifiskiem neiromediatoriem un anatomiskiem smadzeṇu apvidiem (Rothbart \& Bates, 2006, kā minēts Zentner et al., 2008). Trīs minētās temperamenta dimensijas sastāv no vairākām apakšdimensijām. Reaktivitāti veido vairākas apakšdimensijas: aktivitātes līmenis (activity level) - lielo kustību aktivitātes līmenis, tostarp pārvietošanās apjoms un àtrums; pozitīvas gaidas (approach/ positive anticipation) - pozitīva uztraukuma apjoms, gaidot patīkamu aktivitāti; labsajūta no augstas intensitātes stimuliem (high-intensity pleasure) - prieka daudzums, ko gūst no aktivitātēm, kas saistītas ar augstu stimulēšanas intensitāti, ātrumu, sarežǵītību, novitāti un neatbilstību; impulsivitāte (impulsivity) atbildes reakcijas ātrums; zems kautrīgums (shyness [negative loading]) - nekavēšanās 
iesaistīties jaunās vai neskaidrās situācijās; smaidīšana un smiešanās (smiling and laughter) - pozitīvo emociju kopums, reagèjot uz stimulu izmaiṇām - intensitātē, ātrumā, sarežǵìīibā un nesaskaņotībā.. Negatīva emocionalitāte sastāv no apakšdimensijām: dusmas/ vilšanās (Anger/frustration) - negatīvo emociju kopums, kas saistīts ar notiekošo aktivitāšu beigšanos vai atsacǐšanos no mērḳiem; diskomforts (discomfort) negatīvo emociju kopums, kas saistīts ar sensorajām stimulu kvalitātēm, tostarp gaismas, kustību, skaņas un tekstūras intensitāti, tempu vai sarežǵìīibu; reaktivitātes nesamazināšanās un nespēja nomierināties (falling reactivity and soothability (negative loading)) - nespēja atgūties pēc liela distresa, satraukuma vai vispārēja uzbudinājuma; bailīgums (fear) - negatīvo emociju kopums, tostarp nemiers, raizes vai nervozitāte, kas saistīta ar gaidāmajām ciešanām vai distresu un/vai potenciāli apdraudošām situācijām; skumjas (sadness) - negatīvo emociju kopums, pazemināts garastāvoklis un enerǵija, kas saistīti ar ciešanām, vilšanos un objekta pazaudēšanu. Apzināta reakciju kontrole sastāv no apakšdimensijām: uzmanības fokusēšana (attentional focusing) - spēja koncentrēt uzmanību uzdevuma veikšanai; ; labsajūta no zemas intensitātes stimuliem (low-intensity pleasure) - prieka daudzums, ko gūst no aktivitātēm, kas saistītas ar zemu stimulēšanas intensitāti, ātrumu, sarežgìitību, novitāti un neatbilstību; uztveres jūtīgums (perceptual sensitivity) - nelielu un zemu apkārtējās vides stimulu atklāšanas daudzums; spēja apvaldìt reakcijas (inhibitory control) - spēja plānot un apvaldìt savas atbildes reakcijas saskaṇā ar noteikumiem vai nenoteiktā situācijā.

Apzinātas reakciju kontroles individuālās atškịīibas saistītas ar vadības funkcijām, kas lokalizētas uzmanības vadības sistēmas galvas smadzeṇu pieres daivā (Rothbart \& Bates, 2006, kā minēts Zentner et al., 2008). Šie tīkli saistīti ar konkrētiem specifiskiem neiromediatoriem un anatomiskiem smadzeņu apvidiem. Piemēram, uzmanības vadības sistēma ir saistīta ar priekšējo cingulāro garozu, bazālajiem ganglijiem un sānu prefrontālo garozu. Provizoriskie pētījumu dati liecina, ka šīs sistēmas neiromodulatori var saturēt dopamīnu, kas varētu palīdzēt apvaldīt reakcijas. Kopumā Rotbartas apzinātas reakciju kontroles koncepts ir divpusējs - tas ietver gan aspektus, kuri saistīti ar spēju pārslēgt, fokusēt un noturēt uzmanību pēc nepieciešamības, gan ar uzvedības regulēšanu, kas ietver reakciju apvaldī̌̌anu un reakciju aktivēšanu (Zentner \& Shiner, 2012). Kočanska un kolēǵi secinājuši, ka uzmanības fokusēšana deviņu mēnešu vecumā prognozē labākas pašregulācijas spējas attiecībā uz pozitīvu vai negatīvu emocionālo reaktivitāti (Kochanska, Murray, \& Harlan, 2000, kā minēts Zentner et al., 2012). Individuālās atšḳirības apzinātajā reakciju kontrolē saistītas ar dažiem metakognitīvo zināšanu aspektiem, piemēram, prāta teoriju - zināšanām par to, ka indivīda uzvedībā nozīme ir arī pārliecībām, vēlmēm un citiem mentālajiem stāvokḷiem (Carlson, Moses, \& Claxton, 2004, kā minēts Zentner et al., 2012). Apzinātu reakciju kontroli iespējams stiprināt, mijiedarbojoties gēniem un videi. Pašregulācijas spēju attīstību var sekmēt tādi vecāku - bērnu attiecību aspekti kā, piemēram, droša piesaiste, agrīnā savstarpējā saskarsme, emocionālais siltums, atsaucība bērna signāliem, un disciplinēšana - tam ir nozīme bērna pašregulācijas spēju attīstībā (Zentner et al., 2012).

Apzinātajā reakciju kontrolē viena no būtiskākajām apakšdimensijām ir Spēja apvaldīt reakcijas. Tas ir augstākās vadības sistēmas radītais process, kas regulē informācijas apstrādes sistēmas darbību smadzenēs un aktivizē pašregulācijas mehānismus (Williams, Ponesse, Schachar, Logan, \& Tannock, 1999). Tā ir spēja pēkšṇi un pilnībā 
apturēt plānoto vai notiekošo domu un darbību (Logan, 1994, kā minēts Williams et al., 1999). Turklāt runa ir par apzinātu reakciju apvaldīšanu, piemēram, pirmsskolas izglìtības iestādē bērnam jāapvalda vēlme runāt reizè ar citu bērnu. Spēja apvaldīt reakcijas vienlaikus ir būtiska vadības funkciju sastāvdaḷa, un kopumā atkarīga no uzmanības procesu attīstības, kā arī ir svarīgs pietiekams galvas smadzeņu pieres daivas nobriedums (Miyake, Friedman, Emerson, Witzki, \& Howerter, 2000; Morasch \& Bell, 2012, kā minēts Krone, 2013, Posner \& Rothbart, 2000; Posner \& Rothbart, 2007). Šis konstrukts kā vadības funkciju sastāvdaļa tiek dēvēts par augstākās vadības sistēmas radīto procesu, kas regulē informācijas apstrādes sistēmas darbību smadzenēs un aktivizē pašregulācijas mehānismus (Rothbart, 2011; Williams et al., 1999).

Ja par robežu starp grūtībām un spēju veikt nepatieso pārliecību uzdevumus tiek uzskatīts bērnu vecums no trīs līdz pieciem gadiem (Ziv \& Frye, 2003), savukārt apzināta reakciju kontrole parādās bērnam jau ap gada vecumu (par tās pirmssākumu pirmajā dzīves gadā tiek uzskatīta zīdaiņa spēja - reaǵěšana), bet kḷūst spēcīgāka starp otro un trešo dzìves gadu (Rothbart \& Bates, 2006, kā minēts Zentner et al., 2008). Tas nozìmē, ka ap trīs četru gadu vecumu bērnam izteikti attīstās gan apzināta reakciju kontrole, gan prāta teorijas spējas. Turklāt labāka uzmanības fokusēšana uz apzinātu darbỉbu zīdaiṇa vecumā prognozē labākas prāta teorijas spējas pirmsskolas vecumā (Wellman, Lopez-Duran, LaBounty, \& Hamilton, 2008). Spējai apvaldit reakcijas un prāta teorijai ir cieša saistība, un pētnieki piel̦auj, ka tieši spējai apvaldìt reakcijas varētu būt būtiska nozīme prāta teorijas spēju attīstībā bērniem trīs un četru gadu vecumā (Carlson \& Moses, 2001; Carlson, Moses, \& Breton, 2002; Carlson et al., 2004). Tiek arī prognozēts, ka pirmsskolas vecuma bērniem spēja veikt viltus pārliecības uzdevumu, ìpaši, ja labāk attīstīta apzinātā reakciju kontrole, būs aizsargājošs faktors pret naidīguma atribūcijas kḷūdu vēlāk, jaunākajā skolas vecumā (Choe, Olson, \& Sameroff, 2013). Savukārt apzinātas reakciju kontroles, vadības funkciju un nepatieso pārliecību izpratnes mijiedarbība pozitīvi saistīta ar agrīnajām matemātikas un lasišanas spējām nākotnē (Blair \& Razza, 2007). Prāta teorijas mehānisms gan sākas līdz ar pārliecību vēlmju atribūciju, bet efektīva argumentācija par šo pārliecību saturu atkarīga no reakciju apvaldīšanas procesa un tā, kā tiek atlasìtas tās reakcijas, kuras tiek apvaldìtas (Leslie et al., 2004). Modelējot prāta teorijas atlases procesu (theory of mind mechanism selection process) kā selektīvās uzmanības mehānismu, pētnieki ir atklājuši jaunu empīrisku fenomenu un prāta teorijas teorētisko konceptu dēvē par pārāk abstraktu, lai tas bērna dzīvē parādītos pārlieku agri - kamēr bērna zināšanas un argumentācijas spējas kopumā vēl ir ḷoti ierobežotas. Drīzāk tie ir mehānismi, kas virza bērna uzmanību uz mentālajiem stāvoḳ̣liem un atvieglo šo stāvokḷ atpazišanu un apguvi, kas parādās salīdzinoši agri un strauji attīstās. To, ka prāta teorijas spējas, visticamāk, attīstās daudz agrāk par trīs gadu vecumu, taču bērni citu iesaistìto smadzeṇu darbības procesu dēl lielākoties nespēj atbildēt uz nepatieso pārliecību uzdevumu jautājumiem, apstiprina arī Skotas veiktā pētījumu analīze (Scott, 2017). Tajā uzsvērts, ka bērniem nepatieso pārliecību uzdevumos nepieciešams izmantot sarežǵìtus kognitīvos procesus. Piemēram, lai jau iepriekšminētājos Vimmera un Pernera nepatieso pārliecību uzdevumos atbildētu uz jautājumu "Kur stāsta varonis meklēs bumbu?", bērnam vispirms nepieciešamas veikt sarežgîtu atbildes izvēles procesu - bērnam vispirms jāinterpretē jautājums, tad jānolemj atbildēt uz to, un visbeidzot jāizvēlas, kura no atbildēm būtu visatbilstošākā. 
Interpretējot jautājumu, biežākie trigeri ir nepiemērota, spēcīga tendence automātiski atbildēt, balstoties uz bumbin,as aktuālo vietu, nevis to vietu, kurā varonim būtu logiski meklēt bumbu, tādēl bērnam jāspēj apvaldīt šo spontāno, automātisko atbildes reakciju, lai atbildētu, balstoties uz stāsta varoṇa nepatieso pārliecību, ka bumba atrodas vietā, kur tā atstāta. Līdz ar to nepatieso pārliecību uzdevumu izpildē izšķiroša nozìme varētu būt tieši bērna spējai apvaldīt reakcijas, un tādēl ir būtiski noskaidrot, vai un kā prāta teorijas spējas un spēja apvaldīt reakcijas ir saistītas. Tādējādi pētījuma jautājumi ir:

1. Vai bērna vecums ir saistīts ar nepatieso pārliecību izpratni un spēju apvaldìt reakcijas un cik bieži trīs, četrus un piecus gadus veci bērni pareizi atbild nepatieso pārliecību uzdevumos un spēj paveikt reakciju apvaldīšanas uzdevumus?

2. Vai pastāv sakarības starp spēju apvaldīt reakcijas un nepatieso pārliecību izpratni 3-5 gadus veciem bērniem?

3. Cik lielā mērā bērna vecums un spēja apvaldīt reakcijas prognozē bērna prāta teorijas spējas 3-5 gadu vecumā?

\section{Metode}

\section{Dalïbnieki}

Pētijumā piedalījās 52 dalībnieki $(n=52)$ - bērni vecumā no 3 līdz 5 gadiem, tostarp 29 zēni un 23 meitenes. 13 bērni bija trīs gadus veci jeb vecumā no $36 \mathrm{lìdz}$ 47 mēnešiem, 15 bērni bija četrus gadus veci jeb vecumā no 48 līdz 59 mēnešiem, un 23 bērni bija piecus gadus veci jeb vecumā no 60 līdz 71 mēnešiem.

\section{Instrumentārijs}

No bērnu vecākiem tika ievākta informācija par bērnu vecumu un dzimumu.

Nepatieso pārliecību izpratnes jeb prāta teorijas spēju novērtēšanai tika izmantoti Vimera un Pernera nepatieso pārliecību uzdevumi (Wimmer \& Perner, 1983, Perner et al., 1987, latviski tulkojušas Rodzeviča un Sebre, 2011). Tie tika veikti ar katru bērnu individuāli. Prāta teorijas oriğinālo uzdevumu iekšèjās saskaņotības rādītājs ir augsts $(\alpha=0,85)$ (Wimmer \& Perner, 1983).

Vispirms bērniem tiek dots "Negaidītā satura uzdevums" (Perner et al., 1987). Bērniem tiek parādīta kaste, uz kuras attēloti krītiṇi, un bērnam jautā: "Kas atrodas kastēe” Tiek sagaidīts, ka bērns atbildēs, ka kastē ir krītiņi, zīmuḷi u.tml. Tad kaste tiek atvērta, un izrādās, ka tajā ir svecītes. Tad bērnam tiek jautāts: "Ko tu domāji, kas ir šajā kastītē, kad tā vēl netika atvērta?" Ja bērns atbild, ka krītiṇi vai zīmuḷi u.tml., tad par šo atbildi tiek piešķirts 1 punkts, ja bērns atbild, ka sveces, tad tiek piešķirti 0 punkti. Pēc tam tiek jautāts: "Ko domās tava mamma/skolotāja - kas ir šajā kastītē, kamēr viṇa to nebūs atvērusi un paskatījusies?” (Atbilde - krītiṇi vai zīmuḷi, 1 punkts, atbilde: sveces - 0 punkti.) Lielākais iespējamais punktu skaits ir 2 punkti, mazākais iespējamais punktu skaits - 0. Uzdevuma "Negaidītais saturs" iekšējā saskaņotība šajā pētījumā ir laba $(\alpha=0,87)$.

Tad bērnam tiek dots uzdevums "Negaidītās pārmaiņas" (Unexpected Change task). Ar divām lellēm, kurām tiek iedoti vārdi Jānis un Maija, kā arī aizveramu grozu 
un aizveramu kasti un bumbiņu tiek demonstrēts stāsts: Jānis spēlējas ar bumbu, pēc tam ieliek to grozā un iziet no istabas. Tad istabā ienāk Maija, paņem no groza bumbu, paspēlējas ar to un ieliek kastē. Tad bērnam tiek uzdoti eksperimentāli jautājumi: 1) Zināšanu jautājums: Vai Jānis zina, kur ir bumba vai nezina? (Atbildes: nezina 1 punkts, zina - 0 punkti.) 2) Domāšanas jautājums: Ko Jānis domā - kur ir bumba? (Atbildes: grozā - 1 punkts, kastē - 0 punkti.) 3) Rīcības jautājums: Kur Jānis ies meklēt bumbu? (Atbildes: grozā - 1 punkts, kastē - 0 punkti.) Tad tiek uzdoti kontroljautājumi, lai pārliecinātos, vai bērns stāstu ir izpratis: 1) Kur patiesībā ir bumba? (Atbildes: kastē 1 punkts, grozā - 0 punkti.) 2) Kur bumba bija pirms tam? (Atbildes: grozā - 1 punkts, kastē - 0 punkti.) Visos nepatieso pārliecību eksperimentālajos jautājumos saņemtie punkti tiek saskaitīti kopā (kontroljautājumu punkti netiek pieskaitīti). Lielākais iespējamais punktu skaits ir 3 punkti, mazākais iespējamais punktu skaits - 0. Ja bērns kaut vai uz vienu no kontroljautājumiem neatbild pareizi - nesaņem punktu, tad eksperimentālie jautājumi netiek ieskaitīit. Uzdevuma "Negaidītās pārmaiṇas" iekšêjā saskaņotība šajā pētījumā ir pieņemama $(\alpha=0,65)$.

Turpinājumā bērnam tiek dots uzdevums "Maldināšanas stāsts"(Misinformation story) (Perner et al., 1994) - tiek turpināts iepriekšējais stāsts ar vēl vienu lelli, kurai tiek dots vārds Pēteris. Bērnam tiek stāstīts stāsts: Jānis laukā satiek savu brāli Pēteri. Pēteris jautā Jānim: "Kur ir bumba?” Jānis atbild: “Grozā!” Tad bērniem tiek jautāts viens kontroljautājums: "Ko Jānis tikko pateica Pēterim - kur atrodas bumba?" (Atbildes: grozā - 1 punkts, kastē - 0 punkti.) Ja bērns par kontroljautājuma atbildi saṇēmis 0 punktu vai arī uzdevumu nav sapratis, tad turpmākie eksperimentālie jautājumi netiek ieskaitīit. Tad tiek uzdoti eksperimentālie jautājumi: 1) Zināšanu jautājums: Vai Pēteris tagad zina, kur atrodas bumba, vai nezina? (Atbildes: nezina - 1 punkts, zina - 0 punkti.) 2) Domāšanas jautājums: Ko Pēteris tagad domā - kur ir bumba? (Atbildes: grozā - 1 punkts, kastē - 0 punkti.) 3) Rīcỉbas jautājums: Kur Pēteris ies meklēt bumbu? (Atbildes: grozā - 1 punkts, kastē - 0 punkti.) Visos nepatieso pārliecību eksperimentālajos jautājumos saņemtie punkti tiek saskaitìti kopā (kontroljautājumu punkti netiek pieskaitīit). Lielākais iespējamais punktu skaits ir 3 punkti, mazākais iespējamais punktu skaits - 0 . Augstāks iegūto punktu skaits katrā uzdevumā liecina par labāku spēju veikt nepatieso pārliecību uzdevumus. Uzdevuma "Maldināšanas stāsts" iekšèjā saskaņotība šajā pētījumā ir pieņemama $(\alpha=0,62)$.

Spējas apvaldìt reakcijas, kas ir temperamenta dimensijas Apzināta reakciju kontrole apakšdimensija, novērtēšanai ar katru bērnu individuāli tiek veikti divi uzdevumi, lai noteiktu motoro reakciju apvaldǐšanas spēju un verbālo reakciju apvaldīšanas spēju.

Motoro reakciju apvaldī̌̌anas spējas tiek mērītas ar uzdevumu "Piesitieni”" (Tapping task, Diamond et al., 1996; latviski tulkojušas Krone un Bite, 2013), ar kuru tiek novērtēta bērna spēja regulēt motoro reakciju apvaldīšanu. Bērnam tiek iedota nūjiņa, un arī eksperimentētājs paņem sev nūjiņu, bet bērnam paskaidro instrukciju: "Kad es piesitîšu ar nūjiṇu 2 reizes, tev jāpiesit 1 reizi, un otrādi, kad es piesitî̌su ar nūjiṇu 1 reizi, tev jāpiesit 2 reizes". Vispirms eksperimentētājs kopā ar bērnu divas reizes (vai arī lìdz bērns sapratis instrukciju) izmēgina uzdevumu, un tad tiek veikti 10 piesitienu uzdevumi randomizētā, visiem pètījuma dalībniekiem vienādā secībā. Par katru saskanāā ar instrukciju veiktu piesitienu uzdevumu, tiek piešķirts 1 punkts. Beigās visi punkti 
tiek saskaitīti - lielāks punktu skaits liecina par labāku spēju regulēt motoro reakciju apvaldǐšanu. Uzdevuma "Piesitieni” iekšējā saskaņotība latviski tulkotajā oriǵinālajā uzdevuma versijā ir laba $(\alpha=0,84)$, un arī šajā pētijumā uzdevuma iekšèjā saskaņotība ir laba $(\alpha=0,79)$.

Verbālo reakciju apvaldǐšanu mēra ar uzdevumu "Diena - Nakts" (The Day/Night task; Gerstadt et al., 1994, latviski tulkojušas Krone un Bite, 2013). Ar to tiek novērtēta bērna spēja regulēt verbālo reakciju apvaldīšanu un darba atmiṇa 3,5 līdz 7 gadus veciem bērniem, un kurš veidots līdzīgi Džona Strūpa (Jonh Ridley Stroop, 1935) testam (Diamond et al.,1996, kā minēts Krone, 2013). Citos avotos minēts, ka šis uzdevums ietver arī uzmanības fokusēšanas apakšdimensijas novērtēšanu (Gerstadt et al., 1994, kā minēts Zentner et al., 2012). Bērnam pa vienai tiek rādītas vienāda skaita divu veidu kartītes, uz kurām attēlota vai nu Saules vai Mēness un zvaigžņu simbols. Pirms uzdevuma veikšanas bērnam tiek izskaidrota tā instrukcija: "Tev jāsaka "diena”, kad es parādīšu kartīti ar Mēnesi un zvaigznēm, un otrādi, tev jāsaka "nakts", kad es parādīšu kartīi ar Saules attēlu". Vispirms eksperimentētājs kopā ar bērnu divas reizes (vai arī līdz bērns sapratis instrukciju) izmēgina uzdevumu. Tad eksperimentētājs ar bērnu veic 16 uzdevumus - randomizētā, visiem bērniem vienādā secībā: D, N, N, D, N, N, D, D, D, N, D, N, N, D, D, N. Par katru saskaņā ar instrukciju veiktu uzdevumu, tiek piešķirts 1 punkts. Beigās visi punkti tiek saskaitīit - lielāks punktu skaits liecina par labāku spēju regulēt verbālo reakciju apvaldīšanu. Uzdevuma "Diena - nakts" iekšējā saskaņotîba latviski tulkotajā origínālajā uzdevuma versijā ir laba $(\alpha=0,83)$, un arī šajā pètỉjumā uzdevuma iekšèjā saskaņotība ir laba $(\alpha=0,85)$.

\section{Procedūra}

Pētijuma dati, saņemot vecāku aţ̦auju, tika ievākti individuāli pirmsskolas izglìtības iestādē, to iepriekš saskaņojot ar bērnudārza vadītāju, pedagogiem un bērnu vecākiem. Nepatieso pārliecību un reakciju apvaldīšanas uzdevumi tika veikti turpat, pirmsskolas izglìtỉbas iestādē, atsevišksā telpā individuāli ar katru bērnu laika posmā no 2015. gada novembra līdz 2016. gada janvārim. Vispirms tika veikti trīs nepatieso pārliecību uzdevumi, kas vidēji ar katru bērnu ilga 5-10 minūtes, un citā dienā tika veikti motoro reakciju apvaldīšanas un verbālo reakciju apvaldīšanas uzdevumi, kas abi kopā vidēji ar katru bērnu ilga 5-10 minūtes.

Datu apstrāde un analīze. Pētījuma gaitā iegūtie dati tika apkopoti un apstrādāti atbilstoši katra uzdevuma instrukcijai ar sociālo zinātṇu pētījumu datu apstrādes programmu SPSS, kā arī tika veikta korelāciju un regresiju analīze.

\section{Rezultāti}

Lai atbildētu uz pirmo pētijuma jautājumu, cik bieži trīs, četrus un piecus gadus veci bērni pareizi atbild nepatieso pārliecību uzdevumos un cik bieži spēj paveikt reakciju apvaldǐšanas uzdevumus, vispirms tika veikta Pīrsona korelāciju analīze, lai noskaidrotu, vai bērnu vecums ir saistīts ar nepatieso pārliecỉbu izpratni un spēju apvaldīt motorās un verbālās reakcijas. Rezultāti ir apkopoti 1. tabulā. 
1. tabula. Nepatieso pārliecību izpratnes un reakciju apvaldīšanas spējas saistības ar bērnu vecumu $(n=52)$

\begin{tabular}{|c|c|c|c|c|c|}
\hline & \multicolumn{3}{|c|}{ Nepatieso pārliecību uzdevumi } & \multicolumn{2}{|c|}{ Reakciju apvaldišanas uzdevumi } \\
\hline & $\begin{array}{l}\text { Negaidītais } \\
\text { saturs }\end{array}$ & $\begin{array}{l}\text { Negaidītās } \\
\text { pārmainasas }\end{array}$ & $\begin{array}{l}\text { Maldināšanas } \\
\text { stāsts }\end{array}$ & $\begin{array}{l}\text { Motoro reakciju } \\
\text { apvaldišana } \\
\text { (Piesitieni) }\end{array}$ & $\begin{array}{l}\text { Verbālo reakciju } \\
\text { apvaldī̌ana } \\
\text { (Diena - nakts) }\end{array}$ \\
\hline Bērnu vecums & $0,33^{*}$ & $0,52^{* *}$ & $0,68^{\star *}$ & $0,51^{* *}$ & $0,36^{* *}$ \\
\hline
\end{tabular}

${ }^{* *} p<0,01 ;{ }^{*} p<0,05$

Analizējot datus, redzams, ka vecums statistiski nozīmīgi korelē ar nepatieso pārliecību uzdevumiem: Negaidìtais saturs ( $\mathrm{r}=0,33, \mathrm{p}<0,01)$, Negaidītās pārmaiñas ( $\mathrm{r}=0,52, \mathrm{p}<0,05)$ un Maldināšanas stāsts $(\mathrm{r}=0,68, \mathrm{p}<0,05)$. Tāpat vecums statistiski nozīmīgi korelē ar motoro reakciju apvaldī̌sanas uzdevumu Piesitieni $(\mathrm{r}=0,51, \mathrm{p}<0,05)$ un verbālo reakciju apvaldǐšanas uzdevumu Diena - nakts $(\mathrm{r}=0,36, \mathrm{p}<0,05)$. Tātad pastāv statistiski nozīmīgas sakarības starp bērnu vecumu un nepatieso pārliecību izpratni, kā arī pastāv statistiski nozīmīgas sakarības starp vecumu un spēju apvaldìt reakcijas.

Lai iegūtu skaidrāku priekšstatu, cik daudz bērnu trīs, četru un piecu gadu vecumā spēj paveikt katru uzdevumu pilnībā, iegūstot lielāko iespējamo punktu skaitu, kā arī cik daudz bērnu trīs, četru un piecu gadu vecumā šos uzdevumus spēj paveikt tikai dal̦ēji vai arī nespēj paveikt nemaz, tika aprēķināti pareizo atbilžu biežumi katrā vecuma grupā - trīs gadus veco bērnu grupā, kurā iekḷauti bērni vecumā no 36 lìdz 47 mēnešiem, četrus gadus veco bērnu grupā, kurā iekḷauti bērni vecumā no 48 līdz 59 mēnešiem, un piecus gadus veco bērnu grupā, kurā iekḷauti bērni vecumā no 60 līdz 71 mēnesim. Rezultāti apkopoti 2. tabulā.

2. tabula. Trīs, četru un piecus gadus veco bērnu skaits (\%), kuri atbildējuši pareizi uz nepatieso pārliecību uzdevumu jautājumiem un spējuši paveikt reakciju apvaldī̌sanas uzdevumus

\begin{tabular}{|c|c|c|c|c|}
\hline & & \multicolumn{3}{|c|}{ Pareizi atbildējušo bērnu skaits (\%) } \\
\hline & & $\begin{array}{c}\text { 3 gadi } \\
36-47 \text { mēn. } \\
(n=13)\end{array}$ & $\begin{array}{c}4 \text { gadi } \\
48-59 \text { mēn. } \\
(n=15)\end{array}$ & $\begin{array}{c}\mathbf{5} \text { gadi } \\
60-71 \text { mēn. } \\
(n=24)\end{array}$ \\
\hline Nepatieso pärliecību uzdevumi & Punktu skaits & & & \\
\hline \multirow[t]{3}{*}{ Negaidītais saturs } & 2 & $4(30,8)$ & $7(46,7)$ & $13(54,2)$ \\
\hline & 1 & $2(15,4)$ & $4(26,7)$ & $8(33,3)$ \\
\hline & 0 & $7(53,8)$ & $4(26,7)$ & $3(12,5)$ \\
\hline \multirow[t]{4}{*}{ Negaidīīās pārmaiņas } & 3 & $0(0,0)$ & $8(53,3)$ & $16(66,7)$ \\
\hline & 2 & $1(7,7)$ & $1(6,7)$ & $3(12,5)$ \\
\hline & 1 & $2(15,4)$ & $0(0,0)$ & $1(4,2)$ \\
\hline & $\mathbf{0}$ & $10(76,9)$ & $6(40,0)$ & $4(16,7)$ \\
\hline \multirow[t]{4}{*}{ Maldināšanas stāsts } & 3 & $0(0,0)$ & $6(40,0)$ & $11(45,8)$ \\
\hline & 2 & $0(0,0)$ & $3(20,0)$ & $7(29,2)$ \\
\hline & 1 & $1(7,7)$ & $3(20,0)$ & $4(16,7)$ \\
\hline & $\mathbf{0}$ & $12(92,3)$ & $3(20,0)$ & $2(8,3)$ \\
\hline
\end{tabular}




\begin{tabular}{|c|c|c|c|c|}
\hline & & \multicolumn{3}{|c|}{ Pareizi atbildējušo bērnu skaits (\%) } \\
\hline & & $\begin{array}{c}3 \text { gadi } \\
36-47 \text { mēn. } \\
(n=13)\end{array}$ & $\begin{array}{c}4 \text { gadi } \\
48-59 \text { mēn. } \\
(n=15)\end{array}$ & $\begin{array}{c}5 \text { gadi } \\
60-71 \text { mēn. } \\
(n=24)\end{array}$ \\
\hline Reakciju apvaldī̌sanas uzdevumi & Punktu skaits & & & \\
\hline \multirow[t]{3}{*}{ Motoro reakciju apvaldišana (Piesitieni) } & 10-8 & $5(38,5)$ & $13(86,7)$ & $21(87,5)$ \\
\hline & $4-7$ & $5(38,5)$ & $2(13,3)$ & $2(8,3)$ \\
\hline & $0-3$ & $3(23,1)$ & $0(0,0)$ & $1(4,2)$ \\
\hline \multirow[t]{3}{*}{$\begin{array}{l}\text { Verbālo reakciju apvaldīšana } \\
\text { (Diena - nakts) }\end{array}$} & $12-16$ & $7(53,8)$ & $12(80,0)$ & $21(87,5)$ \\
\hline & $6-11$ & $4(30,8)$ & $2(13,3)$ & $2(8,3)$ \\
\hline & $0-5$ & $2(15,4)$ & $1(6,7)$ & $1(4,2)$ \\
\hline
\end{tabular}

Analizējot nepatieso pārliecību uzdevumos iegūtos rezultātus, redzams, ka vecāki bērni šos uzdevumus pilnībā paveikt - iegūt lielāko punktu skaitu - spēj biežāk nekā jaunāki bērni. Piemēram, Negaidìtā satura uzdevumu pilnībā paveikt - iegūt divus punktus - spēj 30,8\% trīs gadus veco bērnu, 46,7\% četrus gadus veco bērnu un 54,2\% piecus gadus veco bērnu. Savukārt uzdevumu Negaidìtās pārmainas pilnībā paveikt, iegūstot trīs punktus, nespēja neviens no trīs gadus vecajiem bērniem, taču spēja paveikt 53,3\% četrus gadus veco bērnu un 66,7\% piecus gadus veco bērnu. Arī uzdevumu Maldināšanas stāsts pilnībā paveikt, iegūstot trīs punktus, nespēja neviens no trīs gadus vecajiem bērniem, taču spēja paveikt $40 \%$ četrus gadus veco bērnu un $45 \%$ piecus gadus veco bērnu. Tātad trīs gadus vecie bērni nepatieso pārliecību uzdevumos Negaidìtās pārmaiñas un Maldināšanas stāsts sniegt pilnībā pareizas atbildes nespēj, bet aptuveni puse četrus un piecus gadus veco bērnu šajos uzdevumos spēj sniegt pilnībā pareizas atbildes.

Analizējot reakciju apvaldīšanas uzdevumos iegūtos rezultātus, vērojams, ka motoro reakciju apvaldīšanas uzdevumu pilnībā vai lielāko dal̦u uzdevuma, iegūstot 8-10 punktus, spēj paveikt $38,5 \%$ trīs gadus veco bērnu, $86,7 \%$ četrus gadus veco bērnu un $87,5 \%$ piecus gadus veco bērnu. Verbālo reakciju apvaldīšanas uzdevumu pilnībā vai lielāko dalı uzdevuma, iegūstot $12-16$ punktus, spēj paveikt $53,8 \%$ trīs gadus veco bērnu, $80 \%$ četrus gadus veco bērnu un $87,5 \%$ piecus gadus veco bērnu. Tas nozīmē, ka bērni četru un piecu gadu vecumā apvaldìt reakcijas spēj biežāk nekā bērni trīs gadu vecumā.

Lai noskaidrotu, vai pastāv sakarības starp spēju apvaldīt reakcijas un nepatieso pārliecību izpratni 3-5 gadus veciem bērniem, tika veikta Pīrsona korelāciju analīze reakciju apvaldīšanas uzdevumu skalām un nepatieso pārliecību uzdevumu skalām. Rezultāti apkopoti 3. tabulā. 
3. tabula. Reakcijas apvaldī̌̌anas spēju un nepatieso pārliecību izpratnes saistības $(\mathbf{N}=\mathbf{5 2})$

\begin{tabular}{lcc}
\hline & \multicolumn{2}{c}{ Reakciju apvaldī̌̌anas uzdevumi } \\
\cline { 2 - 3 } Nepatieso pārliecību uzdevumi & $\begin{array}{c}\text { Motoro reakciju apvaldǐšana } \\
\text { (Piesitieni) }\end{array}$ & $\begin{array}{c}\text { Verbālo reakciju apvaldīšana } \\
\text { (Diena - nakts) }\end{array}$ \\
\hline Negaidītā satura uzdevums & 0,22 & 0,22 \\
Negaidītās pārmaiņas & $0,42^{* *}$ & $0,40^{* *}$ \\
Maldināšanas stāsts & $0,47^{* *}$ & $0,51^{* *}$ \\
\hline
\end{tabular}

${ }^{* *} p<0,01$

Motoro reakciju apvaldīšanas uzdevums Piesitieni statistiski nozīmīgi saistīts ar nepatieso pārliecību uzdevumu Negaidītās pārmaingas ( $\mathrm{r}=0,42, \mathrm{p}<0,01$ ) un Maldināšanas stāsts $(\mathrm{r}=0,47, \mathrm{p}<0,01)$. Statistiski nozīmīga sakarība pastāv arī starp verbālo reakciju apvaldīšanas uzdevumu Diena - nakts un nepatieso pārliecību uzdevumu Negaidītās pārmaiñas $(\mathrm{r}=0,40, \mathrm{p}<0,01)$ un Maldināšanas stāsts $(\mathrm{r}=0,51$, $\mathrm{p}<0,01)$. Tas nozīmē, ka 3-5 gadus vecu bērnu nepatieso pārliecību izpratne, veicot uzdevumus Negaidītās pārmaiņas un Maldināšanas stāsts, ir statistiski nozīmīgi pozitīvi saistīta gan ar motoro reakciju apvaldīšanas spēju, gan ar verbālo reakciju apvaldī̌sanas spēju. Nepastāv statistiski nozīmīgas sakarības starp bērnu spēju pareizi atbildēt uz nepatieso pārliecību uzdevuma Negaidìtais saturs jautājumiem un spēju veikt verbālo reakciju apvaldī̌̌anas uzdevumu Diena - nakts un motoro reakciju apvaldī̌̌anas uzdevumu Piesitieni. Tas nozīmē, ka 3-5 gadus vecu bērnu nepatieso pārliecību izpratne, veicot uzdevumu Negaidìtais saturs, nav statistiski nozīmīgi saistīta ar verbālo un motoro reakciju apvaldīšanas spēju.

Lai atbildētu uz trešo pētījuma jautājumu, cik lielā mērā bērna vecums un spēja apvaldīt reakcijas prognozē bērna prāta teorijas spējas 3-5 gadu vecumā, tika veikta hirearhiskā regresiju analīze. Balstoties uz mainīgo savstarpējo korelāciju, pirmajā regresijas modelī kā atkarīgais main̄̄gais tika iekl̦auti Negaidīto pārmaiṇu uzdevuma rezultāti, bet kā neatkarīgie mainīgie - bērnu vecums, dzimums, motoro un verbālo reakciju apvaldīšanas spējas. Rezultāti apkopoti 4 . tabulā.

4. tabula. Hierarhiskās regresijas analīzes rezultāti ar Negaidìto pārmaiṇu uzdevuma rezultātiem kā atkarīgo mainīgo $(\mathrm{N}=52)$

\begin{tabular}{lcccccc}
\hline Neatkarìgais mainīgais & $B$ & $S E B$ & $\beta$ & $R^{2}$ & Pielägotais $^{2}$ & $F$ \\
\hline 1. solis & & & & 0,27 & 0,26 & $18,46^{* * *}$ \\
Vecums & 0,07 & 0,02 & $0,52^{* * *}$ & & & \\
\hline
\end{tabular}

${ }^{* * *} p<0,001$

Šajā modelī tikai bērnu vecums nozīmīgi prognozē Negaidīto pārmaiṇu uzdevuma rezultātus $(\beta=0,52, \mathrm{p}<0,001)$, kas izskaidro $27 \%$ no variācijas $(\mathrm{F}(1 ; 51)=18,46$, $\mathrm{p}<0,001)$. Bērnu dzimums, motoro un verbālo reakciju apvaldī̌̌anas spējas no model̦a tika izslēgtas.

Otrajā regresijas modelī kā atkarīgais mainīgais tika iekḷauti Maldināšanas stāsta rezultāti un kā neatkarīgie mainīgie - bērnu vecums, dzimums, motoro un verbālo reakciju apvaldī̌̌anas spējas. Rezultāti apkopoti 5. tabulā. 
5. tabula. Hierarhiskās regresijas analīzes rezultāti ar Maldināšanas stāsta rezultātiem kā atkarīgo mainīgo $(\mathrm{N}=52)$

\begin{tabular}{lcccccc}
\hline Neatkarīgais mainīgais & $B$ & $S E B$ & $\beta$ & $R^{2}$ & Pielägotais $R^{2}$ & $F$ \\
\hline 1. solis & & & & 0,46 & 0,44 & $41,79^{* * *}$ \\
Vecums & 0,08 & 0,01 & $0,67^{* * *}$ & & & \\
\hline 2. solis & & & & 0,54 & 0,52 & $28,64^{* * *}$ \\
Vecums & 0,07 & 0,02 & $0,56^{* * *}$ & & & \\
Verbālā apvaldīšana & 1,81 & 0,61 & $0,31^{* *}$ & & & \\
\hline
\end{tabular}

${ }^{* *} p<0,01 ;{ }^{* * *} p<0,001$

Pirmajā solī tikai bērnu vecums nozīmīgi prognozē Maldināšanas stāsta rezultātus $(\beta=0,67, \mathrm{p}<0,001)$, kas izskaidro $46 \%$ no variācijas $(\mathrm{F}(1 ; 51)=41,79, \mathrm{p}<0,001)$. Otrajā solī iekl̦aujot verbālās apvaldī̌sanas spējas, modelis jau izskaidro 54\% no Maldināšanas stāsta rezultātu variācijas $(\mathrm{F}(2 ; 50)=28,64, \mathrm{p}<0,001)$, un pienesums $8 \%$ apmērā ir statistiski nozīmīgs.

Apkopokot iegūtos regresiju analīzes rezultātus, jāsecina, ka prāta teorijas spējas 3-5 gadu vecumā prognozē bērnu vecums abos prāta teorijas uzdevumos un verbālo reakciju apvaldīšanas spējas nepatieso pārliecību izpratnes uzdevuma Maldināšanas stāsts gadījumā. Dzimums un motoro reakciju apvaldīšanas spējas statistiski nozīmīgu pienesumu prāta teorijas spēju prognozē nedod.

\section{Diskusija}

Pētījuma rezultāti liecina, ka pastāv statistiski nozīmīgas sakarības starp bērnu vecumu un nepatieso pārliecību izpratni, kā arī pastāv statistiski nozīmīgas sakarības starp vecumu un spēju apvaldīt reakcijas. Tāpat pastāv arī biežuma atškirīibas, cik lielā mērā paveikt nepatieso pārliecību uzdevumus un motoro un verbālo reakciju apvaldī̌̌anas uzdevumus spēj trīs, četrus un piecus gadus veci bērni. Ja trīs gadus vecie bērni nepatieso pārliecību uzdevumos Negaidītās pārmaiņas un Maldināšanas stāsts sniegt pilnībā pareizas atbildes nespēj, tad aptuveni puse četrus un piecus gadus veco bērnu šajos uzdevumos spēj sniegt pilnībā pareizas atbildes. Kopumā var teikt, ka četrus un piecus gadus vecie bērni reakciju apvaldīšanas uzdevumus pilnībā paveikt - iegūt lielāko punktu skaitu - spēj biežāk nekā jaunāki - trīs gadus veci bērni. Tas saskan ar pētījumiem, kuros minēts - ja trīs gadu vecumā lielākā daḷa bērnu vēl nespēj pilnībā pareizi veikt nepatieso pārliecību izpratnes uzdevumus un reakciju apvaldīšanas uzdevumus, tad pēc četru un 4,5 gadu vecuma lielākā daḷa bērnu to spèj (Wellman et al., 2001; Zentner et al., 2012).

Pētijumā apstiprinājās, ka 3-5 gadus vecu bērnu nepatieso pārliecību izpratne, veicot uzdevumus Negaidītās pārmaiņas un Maldināšanas stāsts, ir statistiski nozīmīgi saistīta gan ar motoro reakciju apvaldī̌sanas spēju, gan ar verbālo reakciju apvaldīšanas spēju. Tas saskan ar iepriekšèjiem pētījumiem, ka spēja apvaldīt reakcijas saistīta ar spēju veikt nepatieso pārliecību uzdevumu un to, ka šie abi konstrukti spēcīgi attīstās gandrīz vienlaikus - ap 3-4 gadu vecumu (Carlson et al., 2001). Lìdz ar to šì sakarība, kas atklājas pētījumā, varētu būt skaidrojama ar to, ka jaunākajiem pētījuma dalībniekiem 
vēl nav pietiekami attīstijjusies spēja apvaldìt reakcijas, turpretī vecākajiem pētījuma dalībniekiem šis konstrukts jau varētu būt labi attīstījies. Tomēr nepastāv statistiski nozīmīgas sakarības starp bērnu spēju apvaldìt verbālās un motorās reakcijas un nepatieso pārliecību izpratni, veicot uzdevumu Negaidìtais saturs. Vienlaikus vērojams, ka tieši uzdevumā Negaidìtais saturs, trīs gadus veci bērni biežāk (30,8\% bērnu) sniedz pilnībā pareizas atbildes nekā abos pārējos nepatieso pārliecību uzdevumos - Negaidìtās pārmaiņas un Maldināšanas stāsts, kuros pilnībā pareizas atbildes nespēj sniegt neviens no trīs gadus vecajiem bērniem. Tādējādi iespējams, ka atbildēt uz Negaidìtā satura uzdevuma jautājumiem bērnam, kurš vēl nav sasniedzis trīs gadu vecumu, ir vieglāk nekā atbildēt uz nepatieso pārliecību uzdevumu Negaidìtās pārmaiņas un Maldināšanas stāsts jautājumiem. Negaidìtā satura uzdevums varētu būt vieglāks tieši tādēḷ, ka to veicot, bērniem nav jāapvalda reakcijas, jo bērni eksperimenta gaitā nemaz nav redzējuši uz iepakojuma attēlotais saturs - eksperimenta gaitā nemaz netiek manipulēts ar krïtiniem, tikai to attēlu (Baillargeon et al., 2010; Rubio-Fernandez, 2016). Iespējams, ja bērni būtu redzējuši krītiņus, un to atrašanās vieta eksperimenta gaitā tiktu mainīta, jaunākiem bērniem būtu grūtāk apvaldīt verbālās reakcijas un viṇi biežāk atbildētu kḷūdaini. Pētnieki jau iepriekš skaidrojuši, ka arī jaunākam bērnam Negaidìtā satura uzdevums varētu būt vieglāks, jo tajā iespējamas tikai divas atbilžu izvēles, atšḳirībā no abiem pārējiem nepatieso pārliecību uzdevumiem (Mitchell \& Lacohée, 1991; Freeman \& Lacohée, 1995, kā minēts Rubio-Fernandez, 2016).

No regresiju analīzes var secināt, ka prāta teorijas spējas 3-5 gadu vecumā prognozē bērnu vecums abos prāta teorijas uzdevumos un verbālo reakciju apvaldīšanas spējas nepatieso pārliecību izpratnes uzdevuma Maldināšanas stāsts gadījumā. Tas apstiprina pētnieku pieṇēmumus, ka prāta teorijas spējas attīstās daudz agrāk par trīs gadu vecumu, taču bērni nespēj atbildēt uz nepatieso pārliecību uzdevumu jautājumiem, jo bērniem nepatieso pārliecỉbu uzdevumos nepieciešams izmantot sarežğìtus kognitīvos procesus jāinterpretē jautājums, jānolemj atbildēt uz to un jāizvēlas, kura no atbildēm būtu visatbilstošākā, kā arī interpretējot jautājumu, jāapvalda spēcīgā tendence automātiski atbildēt uz jautājumu (Scott, 2017). Lìdz ar to arī šì pētījuma rezultāti liecina, ka nepatieso pārliecỉbu uzdevumu izpratnē nozīmīga varētu būt tieši bērna spēja apvaldīt verbālās reakcijas. Tādēḷ ne velti vairāki pētnieki Vimera un Pernera nepatieso pārliecību uzdevumus novērtējuši kā salīdzinoši sarežğìtus jaunākajiem pirmsskolas vecuma bērniem, norādot, ka, piemēram, 3-4 gadu vecumā, iespējams, bērniem ir attīstījušās prāta teorijas spējas, tomēr veikt uzdevumus ir par grūtu, un lai gan tie dậeji parāda arī bērna nepatieso pārliecību izpratni, tomēr nepasaka par to visu (Bloom \& German, 2000). Tāpēc, lai gan joprojām šie nepatieso pārliecỉbu uzdevumi tiek plaši izmantoti pētniecībā, iespējams, turpmākajos pētỉjumos būtu lietderīgi meklēt vēl citu autoru uzdevumus pirmsskolas vecuma bērnu prāta teorijas spēju novērtēšanai. Piemēroti uzdevumi prāta spēju jeb nepatieso pārliecību izpētei varētu būt līdzīgi Vimmera un Pernera nepatieso pārliecību uzdevumiem Negaidìtās pārmaiņas un Maldināšanas stāsts, taču ar pietiekami samazinātu nepieciešamību izmantot sarežğìtos kognitīvos procesus, lai atbildētu uz uzdevuma jautājumiem (Scott, 2017). Tādā gadijjumā būtu iespējams sagaidìt, ka bērni jau 2,5 gadu vecumā spēj izpildìt nepatieso pārliecỉbu uzdevumus (Rubio-Fernandez \& Geurts, 2013; Setoh et al., 2016). Viens gadijums, kad bērns spēj pareizi atbildēt uz nepatieso pārliecību uzdevuma jautājumiem - ja bumbas 
atrašanās vieta bērnam pašam nav zināma, tad ir vieglāk apvaldìt savas atbildes reakcijas, kas citkārt ir balstītas zināšanās par reālo situāciju. Otrs gadījums, kurā bērni, kas jaunāki par trīs gadiem spēj atbildēt pareizi uz nepatieso pārliecību uzdevumiem ir tad, ja bērnam ir iespēja praktiski izmēgināt eksperimentu, kurā tiek samazināta nepieciešamība lietot sarežgìtos atbildes izvēles procesus. To pierāda jaunāka nepatieso pārliecību uzdevuma Negaidītās pārmaiṇas versija, kurā 2,5 gadus veci bērni uzdevumu un cita cilvēka (pieaugušā) sniegtās atbildes uz jautājumiem vēro no malas kā izrādi (Scott et al., 2012). Tad bērns, vērojot eksperimentu no malas, visbiežāk sagaida, ka pieaugušais, kuram tiek uzdoti jautājumi, atbildēs pareizi, un pamanīs, ja pieaugušais atbildēs kḷūdīsies. Pētniece norāda, ka šajā gadījumā, vērojot eksperimentu no malas un neiesaistoties, bērnam izprast nepatiesās pārliecības ir daudz vieglāk, un tad prāta teorijas spējas novērojamas daudz tiešākā veidā, jo bērnam nav nepieciešams lietot atbildes izvēles procesus un reakciju apvaldī̌sanu.

Tāpat turpmāko pētijumu gaitā būtu ieteicams arī kontrolēt bērnu verbālās spējas, jo vairāki no analizētajiem pētījumiem liecina, ka tieši verbālo spēju ierobežojumi var traucēt bērnam pilnvērtīgi veikt gan nepatieso pārliecību uzdevumu, gan reakciju apvaldī̌sanas uzdevumus, lai gan tas ne vienmēr liecina par viņa prāta teorijas vai reakciju apvaldīšanas vājumu (Astington \& Baird, 2005). Būtu arī svarīgi pētìt nepatieso pārliecību izpratnes un temperamenta dimensiju saistību ar darba atmiņu, jo vairākos iepriekš veiktajos pētījumos minēts, ka tas var būt nozīmīgs faktors, kas iesaistìts gan prāta teorijas spējās, gan spējā apvaldìt reakcijas.

Ir svarīgi turpināt izpēti arī par to, kā saistītas prāta teorijas spējas ar citām apzinātas reakciju kontroles apakšdimensijām, kā arī izpētìt, kā šie konstrukti ietekmē cits citu. Turpmākajos pētijumos īpaši vērts pievērsties uzmanības fokusēšanas apakšdimensijas izpētei un tās saistībai ar spēju apvaldìt reakcijas un saistībai ar nepatieso pārliecību izpratni -strādājot mijiedarbībā ar spēju apvaldīt reakcijas, uzmanības fokusēěanai ir liela nozīme apzinātas reakciju kontroles attīstībā (Rothbart, 2011). Lìdz ar to uzmanības fokusēěanai varētu būt nozīmīga loma arī bērna nepatieso pārliecību izpratnē. Vienlaikus pètījumos par nepatieso pārliecību izpratni un spēju apvaldīt reakcijas svarīgi pētīt vai arī kontrolēt bērnu bilingvālismu un monolingvālismu - vairāku pētijumu rezultāti liecina, ka bilingvālu bērnu un arī pieaugušo spējas apvaldìt reakcijas un līdz ar to arī nepatieso pārliecību izpratne mēdz būt labāka, jo bilingvālā pieredze var palīdzēt efektīvāk vadìt uzmanību (Baillargeon et al., 2010). Ir pētijumi, kas liecina, ka 3-4 gadu vecumā bērna izpratnes attīstība par emocijām - laimi, skumjām, dusmām un bailēm ir saistìta ar nepatieso pārliecību izpratnes attīstību jeb tas, cik lielā mērā ir attīstījusies ir bērna izpratne par emocijām, ir saistìts ar to, cik attīstijušāàs ir viṇa prāta teorijas spējas (Wang, Liu, \& Su, 2014). Lìdz ar to turpmāk būtu vērts iedziḷināties un pētīt, vai emociju izpratne noteiktā vecumā ir saistīta ar bērna temperamentu - negatīvās emocionalitātes apakšdimensijām.

Pètījumā rezultātus varēs izmantot turpmākajā bērnu temperamenta un prāta teorijas izpētē, bērnu vecāku, pedagogu un citu speciālistu izglìtošanā par temperamenta dimensijām un prāta teoriju, šo konstruktu nozīmi bērna attīstībā, īpaši tādēl, ka pirmo reizi latviski publicēta detalizēta informācija par temperamenta dimensijām pirmsskolas vecumā iepriekš Latvijā publicētajos pētījumos tikušas apskatītas temperamenta dimensijas zìdaiņa vecumā (Zande \& Sebre, 2014). Tas ir būtiski, jo, 
lai gan pasaulē, piemēram, temperamenta pētniecība pēdējos gadu desmitos ir ļoti plaša, Latvijā, veicot šo pētījumu, tika secināts, ka dažādu bērnu aprūpes speciālistu izpratne visbiežāk par temperamentu ir nepietiekama vai arī šiem speciālistiem ir zināma novecojusi, mūsdienu zinātnes kontekstā neaktuāla informācija. Vienlaikus šì pētījuma atziņas, ka labāka bērna spēja apvaldīt verbālās reakcijas prognozē labāku nepatieso pārliecību izpratni, varēs izmantot pedagogi un citi speciālisti, kas praktiski strādā ar pirmsskolas vecuma bērniem, piemēram, pedagoǵiskajā procesā. Tāpat šī pètijuma atziñas ir noderīgas psihologiem gan praksēe, veicot bērna psiholoğisko izpēti vai uzvedības terapijā, gan arī zinātnē, veicot turpmākus pētījumus par pirmsskolas vecuma bērniem.

Pētījuma rezultātu ņemšana vērā ir noderīga, veicot kriminālprocesā iesaistīta bērna - cietušā vai liecinieka - nopratināšanu. Piemēram, nopratinot bērnu, kas jaunāks par četriem gadiem, ìpaši jāpiedomā pie veida, kā tiek uzdoti jautājumi un iegūta informācija no bērna, ņemot vērā, ka bērnam šajā vecumā vēl nav pietiekami attīstīta spēja apvaldīt verbālās reakcijas, tādēḷ uz tiešā veidā uzdotiem jautājumiem, no bērna iespējams saņemt nepatiesu atbildi, n̦emot vērā, ka bērnam līdz aptuveni četru gadu vecumam pirms atbildes sniegšanas nepieciešams veikt sarežğìtus kognitīvos procesus.

\section{Izmantotā literatūra}

Astington, J. W. \& Baird, J. A. (2005). Why language matters for theory of mind. New York, NY, US: Oxford University Press, 355.

Baillargeon, R., Scott, R. M., \& He, Z. (2010). False-belief understanding in infants. Trends in Cognitive Science, 14, 110-118.

Baron-Cohen, S., Tager-Flusberg, H., \& Cohen D. J. (2000). Understanding other minds: Perspectives from autism and developmental cognitive neuroscience. Second Edition. Oxford: Oxford University Press.

Björkqvist, K., Österman, K., \& Kaukiainen, A. (2000). Social intelligence - Empathy = aggression? Aggression and Violent Behavior, 5, 191-200.

Blair, C., \& Razza, R. P. (2007). Relating effortful control, executive function, and false belief understanding to emerging math and literacy ability in kindergarten. Child Development, 78 (2), 647-663.

Bloom, P., \& German, T. P. (2000). Two reasons to abandon the false belief task as a test of theory of mind. Cognition 77, B25-B31.

Buss, A., \& Plomin, R. (1984). Temperament: Early developing personality traits. Hillsdale, NJ: Erlbaum.

Carlson, S. M., \& Moses L. J. (2001). Individual differences in inhibitory control and children's theory of mind. Child Development, 72(4), 1032-53.

Carlson, S. M., Moses, L. J., \& Breton, C. (2002). How specific is the relation between executive function and theory of mind? Contributions of inhibitory control and working memory. Infant and Child Development, 11, 73-92.

Carlson, S. M., Moses L. J., and Claxton., L. J. (2004). Individual differences in executive functioning and theory of mind: An investigation of inhibitory control and planning ability. Experimental Child Psychology, 87, 299-319. 
Choe, D. E., Olson, S. L. \& Sameroff, A. J. (2013). Effortful control moderates bidirectional effects between children's externalizing behavior and their mothers' depressive symptoms. Dissertation, University of Michigan.

Diamond, A., \& Taylor, C. (1996). Development of an aspect of executive control: Development of the abilities to remember what I said and to "Do as I say, not as I do." Developmental Psychobiology, 29(4), 315-334.

Dore, R. A., \& Lillard, A. S. (2015). Theory of mind and children's engagement in fantasy worlds. Imagination, Cognition and Personality: Consciousness in Theory, Research, and Clinical Practice, 34(3), 230-242.

Drubach, D. (2008). The purpose and neurobiology of Theory of Mind. Journal of Religion and Health, 4 7, 354-365.

Freeman, N. H., \& Lacohée, H. (1995). Making explicit 3-year-olds' implicit competence with their own false beliefs. Cognition, 56, 31-60.

Gerstadt, C. L., Hong, Y., \& Diamond, A. (1994). The relationship between cognition and action: Performance of children 3-7 years old on a Stroop-like day-night test. Cognition, 53(2), 129-153.

Gliga, T., Senju, A., Pettinato, M., Charman, T., \& Johnson, M. H. (2014). Spontaneous Belief Attribution in Younger Siblings of Children on the Autism Spectrum. Developmental Psychology, 50 (3), 903-913.

Kochanska, G., Murray, K. T., \& Harlan, E. T. (2000). Effortful control in early childhood: Continuity and change, antecedents, and implications for social development. Developmental Psychology, 36, 220-232.

Krone, I. (2013). Pirmsskolas vecuma bērnu vadības funkcijas un vecāku-bērnu mijiedarbības sakarības. Latvijas Universitāte. Promocijas darbs psihologijas doktora grāda iegūšanai.

Leslie, A. M., Friedman, O., \& German, T. P. (2004). Core mechanisms in theory of mind. Trends in Cognitive Sciences, Vol. 8 (12), 528-533.

Logan, G. D. (1994). On the ability to inhibit thought or action: A users' guide to the stop signal paradigm. In D. Dagenbach, \& T. H. Carr (Eds.), Inhibitory processes in attention, memory, and learning (pp. 189-239). San Diego, CA: Academic Press.

Mitchell, P., \& Lacohée, H. (1991). Children's early understanding of false belief. Cognition, 39, $107-127$.

Miyake, A., Friedman, N. P., Emerson, M. J.,Witzki, A. H., \& Howerter, A. (2000). The unity and diversity of executive functions and their contributions to complex "Frontal Lobe" tasks: A latent variable analysis. Cognitive Psychology, 41(1), 49-100.

Morasch, K. C., \& Bell, M. A.(2012). Self-regulation of negative affect at 5 and 10 months. Developmental Psychobiology, 54(2), 215-221.

Perner, J., Leekam, S. R., \& Wimmer, H. (1987). Three-year-olds' difficulty with false belief: The case for a conceptual deficit. British Journal of Developmental Psychology, 5, 125-137.

Perner, J., Ruffman, T., \& Leekam, S. R. (1994). Theory of mind is contagious: You catch it from your sibs. Child Development, 65, 1228-1238.

Posner, M. I., \& Rothbart, M. K. (2000). Developing mechanisms of self-regulation. Development and Psychopathology, 12(3), 427-441.

Posner, M. I., Rothbart, M. K., \& Sheese, B. E. (2007). Attention genes. Developmental Science, 10, 24-29. 
Rapacholi, B. M., \& Gopnik, A. (1997). Early reasoning about desires: Evidence from 14- and 18-month-olds. Developmental Psychology 1997, 33 (1), 12-21.

Rodzeviča I. (2011). Empātijas, prosociālas uzvedības un bērna prāta teorijas saistība 5-6 gadus veciem bērniem. Maǵistra darbs, Latvijas Universitāte.

Rothbart, M. K. (2007). Temperament, development, and personality. Asociation for Psychological Science, 16, 207-212.

Rothbart, M. K. (2011). Becoming who we are. Temperament and Personality in Development.

Guilford Series on Social and Emotinal Development. New York: Guilford Press.

Rothbart, M. K., \& Bates, J. E. (2006). Temperament. In W. Damon \& R. Lerner (Series Eds.), \& N. Eisenberg (Vol. Ed.), Handbook of child psychology, Vol. 3. Social, emotional, and personality development (6 ${ }^{\text {th }}$ ed., pp. , 105-176, 99-166). New York: Wiley.

Rothbart, M., K., \& Derryberry, D. (1981). Development of individual diferences in temperament. In M. E. Lamb \& A. L. Brown (Eds.). Advances in developmental psychology (Vol. 1, pp. 37-86). Mahwah, NJ: Erlbaum.

Rothbart, M. K., \& Rueda, M. R. (2005). The development of effortful control. In U. Mayr, E. Awh, \& S. W. Keele (Eds.), Developing individuality in the human brain: A tribute to Michael I. Posner, 167-188. Washington, DC: American Psychological Association.

Rueda, M. R., \& Rothbart, M. K. (2009). The Influence of temperament on the development of coping: the role of maturation and experience. E. A. Skinner, \& M. J. Zimmer-Gembeck (Eds.). Coping and the development of regulation. New Directions for Child and Adolescent Development, 124 (19-31). San Francisco: Jossey-Bass.

Rubio-Fernandez, P., \& Geurts, B. (2016). Why are bilinguals better than monolinguals at falsebelief tasks? Psychonomic Bulletin \& Review.

Rubio-Fernandez, P., \& Geurts, B. (2013). How to pass the false-belief task before your fourth birthday. Psychological Science, 24, 27-33.

Scott, R. M. (2017). The Developmental origins of false-belief understanding. Current Directions in Psychological Science, Vol. 26 (1), 68-74.

Scott, R. M., He, Z., Baillargeon, R., \& Cummins, D. (2012). False-belief understanding in 2,5-year-olds: Evidence from two novel verbal spontaneous-response tasks. Developmental Science, 15, 181-193.

Setoh, P., Scott, R. M., \& Baillargeon, R. (2016). Two-and-a-half-year-olds succed at a traditional false-belief task with reduced processing demands. Proceedings of the National Academy of Sciences, USA, 113, 1360-13365. Siegal, M. \& Varley, R. 2006. Aphasia, language and theory of mind. Social Neuroscience, 1, 167-174.

Siegal, M., \& Varley, R. (2002). Neural systems involved in theory of mind. Nature Reviews, 3, 463-470.

Songhorian, S. (2013). How do we understand others? Empathy and Theory of Mind as two different, but cooperative, mechanism for sensibility. The Online Journal of the Research Centre in Phenomenology and Sciences of the Person, 4, 104-112.

Sundqist, A., \& Ronnberg, J. (2010). Advanced theory of mind in children using augmentative and alternative communication. Communication Disorders Quarterly. No. 31, 86.

Sutton, J., Smith, P., \& Swettenham, J. (1999a). Bullying and 'theory of mind': A critique of the 'social skills deficit' view of anti-social behavior. Social Development, 8, 117-134. 
Swit, C., \& McMaugh, A., (2012). Relational aggression in preschoolers: can theory of mind development explain such complex forms of social manipulation? Conference paper, AARE 2011 Conference Proceedings, Paper Code: 00298.

Wang, Y., Liu, H., \& Su, Y. (2014). Development of preschoolers' emotion and false belief understanding: a longitudinal study. Social Behavior \& Personality: an International Journal, $42(4), 645$.

Watson, A., Nixon, C., Wilson, A., \& Capage, L. (1999). Social interaction and theory of mind in young children. Developmental Psychology, 35, 386-391.

Wellman, H. M., Cross, D., \& Watson, J. (2001). Meta-analysis of theory-of-mind development: The truth about false belief. Child Development, 72, 655-584.

Wellman, H. M., \& Liu, D. (2004). Scaling of Theory-of-Mind tasks. Child Development, 75 (2), 523-541.

Wellman, H. M., Lopez-Duran, S., LaBounty, J., \& Hamilton, B. (2008). Infant attention to intentional action predicts preschool theory of mind. Developmental Psychology, 44(2): 618-623.

Williams, B. R., Ponesse, J. S., Schachar, R. J., Logan, G. D., \& Tannock, R. (1999). Development of inhibitory control across the life span. Developmental Psychology, 35 (1), 205-213.

Wimmer, H., \& Perner, J. (1983). Beliefs about beliefs: Representation and constraining function of wrong beliefs in young children's understanding of deception. Cognition, 13, 103-128.

Zande, D., \& Sebre, S. (2014). Zīdaiṇa temperaments mūsdienu teorijās un pētījumos. Latvijas Universitātes Raksti: Psiholoğija, 801, 83-95.

Zentner, M., Bates, J. E. (2008). Child temperament: an integrative review of concepts, research programs, and measures. European Journal of Developmental Science, 2 (1/2), 7-37. KG, Göttingen: Vandenhoeck \& Ruprecht GmbH \& Co.

Zentner, M., \& Shiner, R. L. (Eds.) (2012). Handbook of temperament. New York: Guilford Press, p: 750.

Ziv, M., \& Frye, D. (2003). The relation between desire and false belief in children's theory of mind: No satisfaction? Developmental Psychology, 39, 859-876. 


\title{
Mātes zināšanas par bērna attīstību, audzināšanu un izjustais sociālais atbalsts pēc piedalīšanās vecāku apmācības programmā "Bērnu emocionālā audzināšana"
}

\author{
Aiga Ukstiņa un Laura Pirsko ${ }^{1}$ \\ Latvijas Universitāte
}

\begin{abstract}
Abstrakts
Vecāku apmācības programma "Bērnu emocionālā audzināšana" ir pierādījusi savu efektivitāti māšu kompetences uzlabošanā un samazinātu bērna uzrādīto grūtību gadījumā, bet ir svarīgi novērtēt vai tiek uzlabotas arī audzināšanas un bērna attīstības zināšanas. Šajā pētījumā piedalījās 60 pirmsskolas vecuma bērnu mātes no, kurām 30 piedalijjās vecāku apmācības programmā "Bērnu emocionālā audzināšana" un 30 mātes bija kontroles grupā. Veikti Zināšanu par bērna attīstību pirmskolas versijas un Izjustā sociālā atbalsta aptauju pirms un pēc mērījumi abām grupām. Pētījuma mērḳis bija konstatēt izmaiņas zināšanās par bērna audzināšanu, attīstību un izjusto sociālo atbalstu un šo lielumu sakarības pēc piedalǐšanās apmācību programmā. Iegūtie rezultāti parādīja, ka statistiski nozīmīgi ir pieaugušas gan māšu zināšanas apmācības programmas laikā, gan arī ir pieaugusi viṇu pārliecinātība par savām zināšanām. Vienlaikus nav konstatējama statistiski nozīmīga atšķirības starp apmācību un kontroles grupu vidējiem rādītājiem. Tika secināts, ka pastāv nozīmīgas sakarības zināšanu precizitātē un māšu izjustajā atbalstā no ğimenes un nozīmīgiem citiem cilvēkiem.
\end{abstract}

Atslēgas vārdi: māte, zināšanas, bērna audzināšana, bērna attīstība, izjustais sociālais atbalsts.

\section{Mother's Knowledge About Child Development, Parenting and Perceived Social Support After Participation in the Parent Training Program "Encouraging Children's Healthy Emotional Development"}

\author{
Aiga Ukstina and Laura Pirsko \\ University of Latvia
}

\begin{abstract}
The parent training program "Encouraging Children's Healthy Emotional Development" has shown to be an effective tool in enhancing the maternal competence and reducing child behavior difficulties, however, it is also important to study whether it improves the mother's knowledge about parenting and child development processes.

This study was based on a sample of 60 preschoolers' mothers: 30 of the mothers participated in the parent training program "Encouraging Children's Healthy Emotional Development"; while the other 30 served as a control group. Both groups were completed the questionnaires
\end{abstract}

1 Corresponding author: Laura Pirsko, University of Latvia, Jurmalas gatve 76, Riga LV-1083, Latvia.

Email: laura.pirsko@lu.lv 
Knowledge of Child Development Preschool Version Inventory, and the Multidimensional Scales of Perceived Social Support. The questionnaires were completed by all mothers before and after the training program. The aim of this study was to identify changes in knowledge about parenting, child development and perceived social support before and after the participation in the program. The results showed an increase in child development knowledge among the mothers who had participated in the program, mainly as a result of increased confidence about their knowledge. However, differences were not discovered by comparing the mean results of the target and control groups. At the same time, it was concluded that there exist statistically significant correlation between knowledge accuracy and perceived support from family and other important people.

Keywords: mother, knowledge, parenting, child development, perceived social support.

Mūsdienās vecākiem bērnu audzināšana kḷūst arvien lielāks izaicinājums, jo sociālajā telpā tiek piedāvātas un no vecākiem pieprasītas daudz plašākas zināšanas par bērnu audzināšanu un attīstību, nekā tas bija dažas desmitgades iepriekš. Attīstības psiholoǵijā veiktie pētījumi gandrīz viennozīmīgi parāda negatīvu saistību starp vecāku bērnu audzināšanas prasmēm un bērna attīstības rezultātiem.

Zināšanas par bērnu audzināšanu un attīstību veiktajos pētījumos tiek saistītas ar vecāka spēju atbilstoši novērtēt bērna uzvedību, palielinātu pašefektivitāti un uzvedības kompetenci audzināšanā, pozitīvāku mijiedarbību ar bērnu, atbilstošu bērna attīstības veicināšanu, mazākām bērna uzvedības grūtībām utt. (Borntein et al., 2003; Hess et al., 2004; Bugental \& Happaney, 2002; Winter et al.; 2012; Bornstein et al, 2010). Zināšanas ir vecāku izpratne par atbilstošu jeb "normatīvu attīstību", kas ietver gan bērna attīstības procesus, gan spējas un sasniegumus, kā arī vecāku izpratni par praksi un stratēǵijām, lai saglabātu un veicinātu bērna veselību un efektīvi tiktu galā ar bērna slimošanu (Bornstein, 2006; Goodnow \& Collins, 1990; MacPhee, 1981).

Jaunākie pētījumi attiecībā uz vecāku zināšanām norāda uz nepieciešamību novērtēt vecāku zināšanas par efektīvām audzināšanas stratēgijām (Winter, Morawska, \& Sanders, 2012). Efektīvas audzināšanas stratēgijas tiek definētas kā pieejas, kas caur empīriski kontrolētu intervenci, vērtējamas kā efektīvas, lai samazinātu vecāku disfunkciju, uzlabotu vecāku pārliecību, un sniegtu pārraudzību un intervenci problemātiskai bērna uzvedībai (Nowak \& Heinrchs, 2008; Prinz et al., 2009). Pētījumu rezultāti l̦auj secināt, ka vecāki, ar salīdzinoši plašākām zināšanām par efektīvām audzināšanas stratēgóijām, uzrāda zemāku trauksmes līmeni un demonstrē lielāku uzvedības kompetenci mijiedarbībā ar viṇu bērniem (Morawska et al., 2009; Winter et al., kā Sanders et al., 2012).

Dažādās valstīs veiktie pētījumi norāda, ka pieaugušās mātes viennozīmīgi uzrāda plašākas audzināšanas zināšanas, nekā mātes pusaudžu vecumā (Benasich \& BrooksGunn, 1996; Dichtelmiller et al., 1992; Hammond-Ratzlaff \& Fulton, 2001; TamisLemonda et al., 2002; McGillicuddy-DeLisi, 1982a, 1982b; Ruchala \& James, 1997, kā minēts Bornstein et al., 2010).

Bērna attīstības nepiemērota novērtēšana var radīt vecākos nepacietību un neiecietību attiecībā pret bērna uzvedību. Ekstrēmos gadījumos neatbilstošas, nepiemērotas 
pārliecības par bērna attīstības spējām var tikt saistītas ar nolaidīgu un vardarbīgu bērna audzināšanu (Cowen, 2001; de Lissovay, 1973; Peterson, Gable, Doyle, \& Ewigman, 1997, kā minēts Reich, 2005). Šis izpratnes "deficìts" mijiedarbībā ar bērnu, var tikt daḷēji izskaidrots ar nereālistiskām jeb neatbilstošam idejām par bērniem kopumā, sagaidot pārāk daudz attiecībā uz bērna paškontroles spējām un kognitīvo attīstîbu (Becker, 1987). Mātes neprecīzs novērtējums - visbiežāk bērna attīstības pārvērtēšana tiek uzrādīta kā cieši un negatīvi saistīta ar bērna problēmu risināšanas spējām vai mācību sasniegumiem (Hunt \& Paraskevopoulos, 1980; Miller, 1986; Stoiber, 1992). Tomēr ir arī pētījumi, kas atklāj pretējo - to māšu bērni, no kuriem sagaidīja lielākas kognitīvās spējas agrīnā bērna vecumā, bija vēlāk labāk novērtēti mācībās (Hess, Holoway, Dickson, \& Price, 1984).

Sociālais atbalsts. Sociālo atbalstu kā plašāku konstruktu iespējams aplūkot vairākās kategorijās. Atbalstu var iedalīt pēc tā saņemšanas veida (piemēram, informatīvs, emocionāls, instrumentāls), pēc avota (piemēram, profesionālie darbinieki aprūpes sfērā, ǵimene, vienaudži, partneris), pēc specifikas (individuāli, grupā, institūcijā), biežuma (piemēram, gada, nedēḷas vai ikdienas kontakts) un pēc ilguma (piemēram, nedēla, mēnesis vai gads) (Stewart, 2000). Papildus vēl tiek noradītas sešas citas dimensijas sociālajam atbalstam: emocionālā, ieteikuma, praktiskā, socializācijas, materiālā un atgriezeniskās saites dimensija (Vaux, 1988, kā minēts Bernal et al., 2003).

Definējot šo jēdzienu ir nepieciešams izprast atšķirības starp indivīda faktisko jeb reālo un izjusto sociālo atbalstu. Faktiskais atbalsts ir atbalsts, kas tiek saņemts caur sarunu, materiālu palīdzību vai darbību indivīda labā. Izjustais sociālais atbalsts ir saistāms ar indivīda pārliecību, ka sociālais atbalsts ir pieejams, kopumā tiek uztverts pozitīvi vai negatīvi un sniedz indivīdam to, kas tiek izjusts kā nepieciešams (Noris \& Kaniastry, 1996).

Kā parāda pētījumi, izjustais sociālais atbalsts ir nozīmīgs komponents cilvēka mentālās veselības nodrošināšanā. Tas potenciāli pasargā cilvēku no dažādām fiziskām un psiholog̣iskām saslimšanām, turpretī sociālā atbalsta trūkums tiek saistìts ar stresu, depresiju un mentālās veselības problēmām, kā arī psihosomatiskiem traucējumiem (Cobb, 1976; Gottlieb, 1985; Newby-Fraser, \& Schlebusch, 1997, kā minēts Bernal et al., 2003).

Raksturojot sociālo atbalstu kā emocionālu, instrumentālu un informatīvu palīdzību (Crockenberg, 1988), pētījumi parāda, ka gan formālā atbalsta sistēma (skola, bērnu aprūpes un vecāku izglìitības programmas, drukātie materiāli un profesionāḷi), gan neformālā atbalsta sistēma (ǵimene un draugi) kopumā ietekmē pieauguša cilvēka funkcionēšanu un specifiski ietekmē indivīda kā vecāka lomu (Cohen \& Wills, 1985; Cochran \& Niego, 2002; Coterell, 1986, kā Bornstein et al., 2006).

Vecāku apmācības programmas. Pēdējās desmitgadēs veiktie pētỉjumi parāda, ka zināšanas par bērnu attīstību un audzināšanu ir sensitīvas attiecībā uz intervenci jeb iedarbību, kas var būt pieejama gan caur formālo izglitību vidusskolā, koledžāà vai augstskolā, gan arī caur dažādām vecāku apmācības programmām (MacPhee, 1981, 2002). Vecāku programmas galvenokārt ir veidotas, lai sniegtu ìslaicīgu intervenci, ar mērḳi vecākiem uzlabot zināšanas par bērnu audzināšanu un attīstību, attiecības ar bērnu un veikt preventīvos vai terapeitiskas intervences pasākumus dažādām uzvedības un emocionālām grūtībām (Barlow \& Parsons, 2003). 
Pētijumi parāda, ka mācību un intervences programmu efektivitāti nosaka dažādi faktori, kā piemēram, bērna vecums, mātes vecums, izglìtības līmenis, sociālais atbalsts, vecāku līdzdarbošanās apmācības procesā (Gardner, et al., 2009; Lundahl, Nimer, \& Parsons, 2006; Stolk, et al., 2007; Nix, et al., 2009, kā minēts Skreitule Pikše, 2010).

Veiktie pētījumi par vecāku apmācību grupu efektivitāti, sistemātiskos pārskatos parāda, ka kopumā tie ir efektīvi 3 līdz 10 gadus veciem bērniem, uzlabojot uzvedību dažādos aspektos un radot izmaiṇas mātes psihoemocionālajā stāvoklī, ieskaitot samazinātu trauksmi, depresiju, un paaugstinātu pašvērtējumu (Barlow, 2000, kā minēts Barlow, \& Parsons, 2007).

Latvijā pirmā šāda veida vecāku apmācības programma tika ieviesta un adaptēta no Kanādas 2004. gadā ar nosaukumu "Bērnu emocionālā audzināšana” jeb saīsinājumā "BEA". Programma ir izveidota pirmsskolas vecuma bērnu vecākiem ar mērḳi sniegt zināšanas, prasmes un paņēmienus, lai palīdzētu mainīt bērnu uzvedību un veicinātu viņu emocionālo un personības attīstību. Vecāku apmācība tiek balstìta uz 10 soḷu programmu. Vecāku izglītošana un apmācība šajā programmā saistās ar dažādām bērnu audzināšanas sfērām un aspektiem. Mērḳi ir gan uzlabot vecāku zināšanas par mazu bērnu attīstību, kā arī papildināt zināšanas par audzināšanas principiem, kas ir svarīgi bērna dzìves pirmajos gados, gan arī palīdzēt vecākiem mainìt negatīvos uzskatus (atribūcijas) un saredzēt pozitīvo bērnā. Vienlaikus palīdzēt vecākiem attīstìt pašregulāciju spējas sevī un bērnā, emocionāli atbalstìt bērnus un veicināt vecāku sociālo mijiedarbību utt. Programmā kopumā tiek ietverti desmit faktori, kas ir zinātniski pētnieciski pierādīti kā nozīmīgi bērnu emocionālajai audzināšanai - vecāku izpratne par bērnu attīstību un temperamentu, bērna k̦ermeņa paškontrole un pozitīvs ķermen̦a pašvērtējums, droša piesaiste, spēelěšanās un fantāzija, valoda un komunikācijas spējas, pozitīva pašcieņa, disciplinēšanas metodes, kas veicina pašregulāciju un attīsta sirdsapziņu, emociju pašregulācija, koncentrēšanās, plānošana un problēmu risināšanas spējas, sociālā kompetence, empātija un gādīgums (Lendija \& Ozola, 2004).

Kopumā par BEA programmas efektivitāti līdz šim ir veikti 3 pētijjumi: divi no tiem Kanādā un viens Latvijā (Landy, et al., 1997; Landy \& Thompson, 2006; Skreitule-Pikše, 2010). Viens no Kanādā veiktajiem pētījumiem ir pilotāžas pētījums, kurā tika izvirzīts mērkis novērtēta programmas efektivitāte, samazinot agresiju un citas eksternalizētas uzvedības grūtības pirmsskolas vecuma bērniem, kuru vecāki bija iesaistīi šajā programmā. Papildus tika vērtēta intervences nozīme vecāku mijiedarbībā ar bērnu un uztverē par saviem bērniem.

Programmā tiek izmantotas dažādas apmācības stratēgijas, kas ietver vairāk gan didaktiskas metodes sniedzot zināšanas par bērna attīstības spējām, gan arī lomu spēles un grupu uzdevumus, kas l̦auj vecākiem attīstìt prasmes un mājasdarbi, kas sniedz iespēju pielietot katra soḷa principus praktiski kopā ar bērnu. Pētījumā veikti mērījumi pirms un pēc vecāku piedalǐšanās programmā, bet pētỉjuma rezultātu ierobežo iztrūkstošā kontrolgrupa. Pētỉjumā iegūtie rezultāti parādīja, ka piedalǐšanās programmā, nozīmīgi uzlabojās bērnu uzvedība un samazinājās agresīva un delikventa uzvedība, mātes uzrādīja lielāku sensitivitāti mijiedarbībā ar bērnu, kḷuva atsaucīgākas uz bērna vajadzībām, kā arī spēja pielietot atbilstošākas tehnikas gan spēlē, gan uzdevumu strukturēšanā. Pētijuma autori norāda, ka jaunās zināšanas, ko mātes ieguva 
par attīstību, audzināšanas stratēgijām, un pārskatu par pašu bērnības pieredzi varēja veicināt izmaiņas vecāku skatījumā uz sevi un saviem bērniem (Landy, Menna, \& Sockett-Dimarcio, 1997).

Savukārt otrā pētijjumā tika novērtēta programmas efektivitāte bērniem, kuriem bija dažādas "uzvedības grūtîbas" - hroniska nepiekāpšanās, neiesaistī̌šanās, izteiktas dusmu lēkmes un agresivitāte, kontroles trūkums utt. Šajā pētijumā tika izvirzìti mērḳi - samazināt bērnu uzvedības grūtību simptomātiku, uzlabot audzināšanas stratēégijas, kā arī palielināt vecāku zināšanas un kompetenci. Šoreiz pētijjuma dizainā tikai ietverta gan intervences grupa, gan kontrolgrupa un veikti mērījumi pirms un pēc piedalǐšanās programmā. Līdzīgi kā pirmajā pētỉjumā, bērni, kuru mātes piedalījās programmā, uzrādīja mazāk uzvedības grūtību, nekā kontroles grupā. Veiktie mērījumi parādỉja, ka intervences grupa nozīmīgi ir uzlabojusies līdzdarbošanās un efektivitāte mātes lomā, lielāks sociālais atbalsts, palielināta iesaistišanās audzināšanā un efektīvāka ierobežojumu noteikšana bērnam un kontroles izjūta kā vecākam. Pēc piedalīšanās programmā mātes uzrādīja arī lielākas zināšanās par bērna attīstību un audzināšanu, salīdzinājumā ar kontroles grupu. Vienlaikus kontroles grupa uzrādīja pat salīdzinoši vājākas zināšanas, nekā sākotnējā mērījumā (Landy \& Thompson, 2006).

Nozīmīgu pētījumu savā doktora darba disertācijā par "Bērnu emocionālās audzināšanas" grupu efektivitāti Latvijā izstrādāja Skreitule - Pikše (Skreitule-Pikše, 2010, nepublicēts materiāls). Šajā pētỉjumā iegūtie rezultāti uzradīja, ka salīdzinājumā ar kontrolgrupu, pēc piedalīšanās "Bērnu emocionālās audzināšanas programmā" palielinājās māšu kompetences izjūta attiecībā uz bērnu audzināšanu un samazinājās pirmsskolas vecuma bērnu uzvedības problēmas, kā arī šìs izmainas tika konstatētas kā noturīgas arī pēc 6 mēnešiem (Skreitule - Pikše, 2010).

Lai gan daudzas vecāku apmācības programmas cenšas izglìtot vecākus attiecībā uz zinātniski - pētnieciski pierādītām zināšanām par bērnu attīstību, tomēr trūkst pētijumu par to, cik efektīivi šìs zināšanas tiek nodotas vecākiem un vai tās ietekmē atbilstošu jeb bērna vecumposmam piemērotu audzināšanu. Lìdz ar to tiek izvirzìti sekojoši pētijuma jautājumi:

1. Vai pastāv statistiski nozīmīgas izmaiņas zināšanās par bērnu audzināšanu, attīstību un izjusto sociālo atbalstu mātēm pèc piedalīšanās "Bērnu emocionālās audzināšanas programmā"?

2. Vai pastāv statistiski nozīmīga saistība starp mātes zināšanām par bērna attīstību, audzināšanu un izjusto sociālo atbalstu pēc piedalīšanās "Bērnu emocionālās audzināšanas programmā”?

\section{Metode}

\section{Pētỉjuma dalïbnieki}

Pētījuma izlase ir 60 pirmsskolas vecuma bērnu mātes, kas sadalītas divās apakšgrupās. Katrā no grupām - apmācību un kontroles ir 30 dalībnieces. Māšu vecums izlasē ir no 25 līdz 42 gadiem. Kontroles grupā vidējais vecums mātēm bija 33,36 gadi $(\mathrm{SD}=4,29)$ un apmācību grupā $31,80(\mathrm{SD}=4,25)$. Dalībnieki ir iesaistīti 
pètījumā pèc brīvprātības principa. Kopumā pētỉjumā piedalījās un vismaz vienu no pētijuma posmiem veica 130 dalïbnieces, bet pètījuma nosacỉjumiem atbilstošas ir 60 respondentu anketas.

Netiek konstatētas statistiski nozīmīgas atšḳirības un grupas ir savstarpēji līdzīgas māšu vidējā vecumā, izglītîbas līmenī, novērtētajā materiālajā labklājībā un bērnu skaitā. Apmācību grupā iekḷautajām mātēm ir salīdzinoši gados jaunāki bērni, nekā kontroles grupas bērni $(\mathrm{t}=2,52, \mathrm{p}<0,05)$. Kontroles grupas mātes norāda, ka salīdzinoši izjūt vairāk atbalstu no partnera bērnu audzināšanā, nekā apmācības grupas mātes $(t=2,47$, $\mathrm{p}<0,05)$. Apmācības grupas mātes salīdzinoši jau iepriekš ir apmeklējušas apmācības par bērnu audzināšanu, nekā kontrolgrupa $(\mathrm{t}=-2,55, \mathrm{p}<0,05)$.

Pirmais bērns apmācību grupā 12 mātēm jeb 40,0\% un kontroles grupā ir 15 mātēm jeb 50,0\%. Pētījuma dalībnieču izglîtîbas līmenis grupās variē no vidējās - speciālās izglìtîbas līdz augstākajai izglìtībai. Apmācību grupā - 66,0\% jeb 20 mātēm ir augstākā izglìīiba, 26, 7\% jeb 8 mātēm ir nepabeigta augstākā izglìīiba un tikai 6, 6\% jeb divām mātēm ir vidèjā speciālā izglîtība. Turpretī kontroles grupā 18 mātēm jeb 60,0\% ir augstākā izglìtība, nepabeigta augstākā izglìtība ir 6 jeb 20,0\% un vidējā speciālā arī ir 6 mātēm jeb 20,0\%. (skat. 1. tabulu).

\section{1. tabula. Pētỉjuma dalībnieku uzrādītie demogrāfiskie rādītāji un to atšksirības starp grupām}

\begin{tabular}{|c|c|c|c|c|c|}
\hline \multirow[b]{2}{*}{ Demogrāfiskais lielums } & \multicolumn{2}{|c|}{ Apmācību grupa } & \multicolumn{2}{|c|}{ Kontroles grupa } & \multirow{2}{*}{$t$} \\
\hline & $\mathrm{M}$ & SD & $\mathrm{M}$ & SD & \\
\hline Vecums & 31,80 & 4,25 & 33,36 & 4,29 & 1,41 \\
\hline Izglītība & 6,60 & 0,62 & 6,40 & 0,81 & $-1,07$ \\
\hline Materiālā labklājība & 2,40 & 0,85 & 2,56 & 0,56 & 0,88 \\
\hline Bērnu skaits & 1,76 & 0,72 & 1,60 & 0,67 & $-0,92$ \\
\hline Bērnu vecums & 3,74 & 1,32 & 4,63 & 1,36 & $2,52^{*}$ \\
\hline Partnera atbalsts & 1,73 & 0,94 & 2,36 & 1,03 & $2,47^{*}$ \\
\hline Apmācības & 1,53 & 2,16 & 0,43 & 0,93 & $-2,55^{*}$ \\
\hline
\end{tabular}

$n=30,{ }^{*} p<0,05$

\section{Instrumenti}

Lai iegūtu demogrāfiskos rādītājus visiem respondentiem tika lūgts aizpildīt "Demogrāfisko datu" aptauju, kurā katram dalībniekam bija jāatzīmē savs un bērna vecums, gimenes stāvoklis, izglìtỉbas līmenis, izjustais atbalsts no partnera un iepriekšējo apmācību pieredze saistībā ar bērnu audzināšanu.

Mātes tiek iesaistìtas vecāku apmācības programmā "Bērnu emocionālā audzināšana", lai veiktu manipulāciju ar atkarīgo mainīgo - māšu zināšanām par pirmsskolas vecuma bērnu attīstību, audzināšanu un izjusto sociālo atbalstu. "Bērnu emocionālās audzināšanas" (BEA) programma ir izveidota Kanādā ("Encouraging Children’s Healthy Emotional Development", Landy, 1995; Landy, 2002; Landy, et al., 1997; Landy \& Thompson, 2006). Programma ir paredzēta pirmsskolas bērnu vecākiem. Latvijā 2004. gadā šo programmu ir adaptējušas Sāra Lendija un Edīte Ozola (Lendija \& Ozola, 2004). Programma ir piemērota gan vecākiem, kuri vēlas iegūt 
papildus zināšanas par bērnu audzināšanu un palīdzēt saviem bērniem kḷūt emocionāli kompetentiem, gan arī vecākiem, kam ir nopietnas grūtỉbas bērnu audzināšanā. Kā viens no BEA mērḳiem ir zināšanu uzlabošanu par pirmskolas vecuma bērnu attīstību un vecāku zināšanu papildināšana par audzināšanas principiem, kas ir svarīgi bērna pirmajos dzīves gados (Lendija \& Ozola, 2004). "Bērnu emocionālās audzināšanas" programmu veido 10 nodarbības jeb soḷi, kurās vecāki tiek izglītoti un iesaistīti dažādu ar bērnu audzināšanu saistītu tēmu aspektos. Vecāku grupu nodarbỉbas vada 2 vadītāji. Dalībnieku skaits grupās variē no 6 līdz 15 dalībniekiem. Viena soḷa jeb nodarbības ilgums ir no 2, 5 līdz 3 stundām, programmas ilgums - 10 nedēl̦as.

Lai novērtētu pētījuma atkarīgo mainīgo - zināšanas. Pētījumā tiek izmantota "Zināšanu par bērna attīstību" pirmskolas versija (Knowledge of infant Development Inventory, preschool version, KIDI - P, MacPhee, 1981, 2002). Latvijā aptauja ir adaptēta 2011. gadā, Aigas Ukstiņas bakalaura darba ietvaros (Ukstiņa, 2011, nepublicēts materiāls).

Aptaujas orig̣inālās versijas iekšejjās saskaņotỉbas ticamības rādītājs normatīvajā pētijjumā $\alpha$ ir 0,82 (MacPhee, 1981). Citos pètijumos ticamības rādìtājs tipiski variē no $\alpha=0,80-0,86$ (Normative, 1981; Head Start, 2001; Hamilton \& Orme, 1990; Ruchala \& James, 1997, kā minēts MacPhee, 1981, 2002). Latviešu valodā adaptētajai KIDI - P aptaujai veiktā Kronbaha Alfas ticamības pārbaude uzrādīja, ka $\alpha=0,76$. Iegūtie rezultāti norādỉja, ka aptaujas jautājumu iekšèjā saskaņotība ir pietiekami laba, lai varētu veikt tālāko statistisko datu analīzi (Ukstiņa, 2011, nepublicēts materiāls).

Aptaujā ietvertās bērna attīstības un audzināšanas sfēras: normas un attīstības posmi (raksturota ir tipiska bērna uzvedība konkrētajā vecumposmā un motorās, uztveres un kognitīvas kompetences. Iekḷautas ir audzināšanas normas attiecỉbā uz bērna raudāšanu, barošanu un autiṇbiksišu mainišanu), principi (plaša kategorija, kas ietver apgalvojumus par attīstības likumsakarībām, kas novērojamas normālā bērna attīstības procesā, aksiomām un vispārzināmām patiesībām, vispārējo prasmju raksturojumu gan bērniem ar netipisku, gan tipisku attīstību), audzināšana (saistìta ar instrumentālajām pārliecībām, ko vecāki izmanto bērna audzināšanas stratēǵijās. Vecāku menedžmenta un atbildības prasme attiecībā uz bērnu, kas tiek parādīta caur mācī̌nanu vai modelēšanu) un veselība un drošỉba (zināšanas kā atbilstoši veikt bērna barošanu un veselības aprūpi, nelaimes gadījumu paredzēšanu un novēršanu, bērna slimības identifikāciju un ārstēšanu). Aptauju veido 58 apgalvojumi. Katrs apgalvojums ir novērtējams 3 vai 4 pakāpju Likerta skalā, kur no 1. līdz 39. apgalvojumam - "piekrītu" (1 punkts), "nepiekrītu" (2 punkti), kā arī "neesmu pārliecināta" (3 punkti). Apgalvojumos no 40. līdz 58. ir 4 pakāpju Likerta skala, kurā respondentiem tiek piedāvāts novērtēt bērna attīstības spējas jeb kompetences konkrētajā vecumā. Šajā gadījumā iespējami atbilžu varianti ir "piekrītu" (1 punkts) un gadījumā, ja respondents apgalvojumam nepiekrìt tiek dota iespēja izvērtēt vai to var paveikt "jaunāks" (2 punkti), "vecāks" (3 punkti) bērns, kā arī ir piedāvāta atbilde "neesmu pārliecināts" (4 punkti), ja respondents izjūt šaubas par savām zināšanām. Aptaujā iegūtie rezultāti tiek skaitīti kā "pareizi, nepareizi vai neesmu pārliecināta”. Aptaujas rezultāti tiek aprēḳināti šādā skalās:

1) Zināšanu pārliecinātība - rādītājs, kas atspoguḷo intensitāti ar ko tiek lietota "neesmu pārliecināts" atbilde. 
2) Zināšanu precizitāte - pareizo atbilžu proporcionāls rādītājs, ka parāda respondenta atbilžu saskanīgumu ar empīriskiem secinājumiem par bērnu attīstïbu.

3) Attīstības spēju jeb kompetenču novērtēšana - šĩ kategorija atspoguḷo nepareizās atbildes divos aptaujas rādītājos: bērna spēju "Pazemināšana" jeb nepietiekama novērtēšana vai "Pārvērtēšana"

4) Kopējās zināšanas - uzrāda respondenta kopēju rezultātu aptaujā. Skala veidojas apvienojot pārliecināto un precīzo atbilžu skalas

Lai varētu novērtēt otru atkarīgo mainīgo lielumu ir izmantota - "Sajustā sociālā atbalsta aptauja" (The multidimensional Scales of Perceived Social Support (MSPSS) Zimet, Dahlem, Zimet, Farley, 1988), kas ir adaptēta Latvijā (Voitkāne, Miezīe, \& Raščevska, 2004). Aptaujas ticamības jeb iekšêjās saskaņotības rādītājs ir $a=0,75$. Aptauju sastāv no 12 apgalvojumiem par dažādiem atbalsta saņemšanas veidiem Katrs apgalvojums ir mērīts Likerta skalā no -3 līdz +3 , kur "-3" apzīmēe "pilnīgi nepiekrītu" un “+3"apzīmē " pilnīgi piekrītu." Aptauju veido trīs apakšskalas ar 4 apgalvojumiem katrā: sajustais atbalsts gimenē, sajustais atbalsts no draugiem, sajustais atbalsts no citiem nozīmīgiem cilvēkiem.

\section{Procedūra}

Abās grupās dati tika ievākti divu gadu garumā. Respondenti pētijumā piedalīiās pēc brīvprātības principa, aptauju aizpildišana notika individuālos darba apstākḷos. Respondentu anonimitāte tika nodrošināta, ievietojot aptaujas aizlīmējamās aploksnēs. Kontroles grupas respondentu anketas tika ievāktas četrās pirmsskolas izglítības iestādēs. Datu ievākšana gan apmācības, gan kontroles grupa notika divas reizes - pirms un pēc BEA programmas jeb 10 nedẹl̦ām.

Pētijumā veiktajai manipulācijai ar atkarīgo mainīgo (apmācībai) ievēroti šādi nosacijumi: visi grupu vadītāji ir ar augstāko izglìtību psihologijā vai sociālajā darbā, un šì ir viṇu pirmā pieredze, ìstenojot programmu. Visās grupās ir 2 vadītāji, kuri ir novadijušsi pilnu 10 soḷu jeb nodarbību programmu un katras grupas darbība ir pārraudzīta pieredzējuša supervizora vadībā. Pētījumā ir iesaistīti tikai tie dalībnieki, kas ir pabeiguši

\section{Rezultāti}

Lai atbildētu uz pētỉjuma jautājumu par to, vai pastāv statistiski nozīmīgas izmaiņas zināšanās par bērna attīstību, audzināšanu un sociālo atbalstu mātēm pēc piedalī̌sanās "Bērnu emocionālās audzināšanas programmā" tika veikta jaukta tipa dispersiju analīze (ANOVA) atkārtotiem mērïjumiem. Izmantojot šo statistikas metodi 2 x 2 grupu dizainam ir noteikts, vai pastāv statistiski nozīmīga atškịīibas starp vidējiem iekšgrupas radītājiem pirms un pēc eksperimentālās manipulācijas jeb apmācību programmas un vai pastāv atškịinibas starp abu grupu vidējiem rādītājiem (skat. 2. tabulu). 


\section{2. tabula. Apmācību un kontroles grupas mainīgo rādītāju aprakstošās un secinošās} statistikas rādītāji pirms un pēc māšu piedalīšanās apmācības programmā

\begin{tabular}{|c|c|c|c|c|c|c|c|c|}
\hline \multirow[t]{2}{*}{ Main̄̄gie lielumi } & \multirow[t]{2}{*}{$\begin{array}{c}\text { Grupa } \\
(n=30)\end{array}$} & \multicolumn{2}{|c|}{$\begin{array}{c}\text { Pirms } \\
\text { eksperimentālās } \\
\text { manipulācijas } \\
\text { veikšanas } \\
\end{array}$} & \multicolumn{2}{|c|}{$\begin{array}{c}P \bar{e} c \\
\text { eksperimentālās } \\
\text { manipulācijas } \\
\text { veikšanas } \\
\end{array}$} & \multicolumn{3}{|c|}{$\begin{array}{c}\text { ANOVA } \\
\text { atkārtotiem } \\
\text { mērījumiem }\end{array}$} \\
\hline & & M & SD & $\mathrm{M}$ & SD & $\begin{array}{l}\text { Grupa } \\
(\mathrm{A})^{\mathrm{a}}\end{array}$ & $\begin{array}{l}\text { Laiks } \\
(\mathrm{B})^{\mathrm{a}}\end{array}$ & $\mathrm{A}^{\mathrm{a}} \times \mathrm{B}$ \\
\hline \multirow{2}{*}{ Zināšanas kopā } & E. gr. & 0,50 & 0,08 & 0,57 & 0,05 & 0,07 & $9,05^{\star *}$ & $16,96^{* *}$ \\
\hline & K. gr. & 0,53 & 0,06 & 0,52 & 0,08 & & & \\
\hline \multirow{2}{*}{$\begin{array}{l}\text { Zināšanu } \\
\text { precizitāte }\end{array}$} & E. gr. & 0,65 & 0,07 & 0,67 & 0,05 & 0,06 & 3,04 & 0,01 \\
\hline & K. gr. & 0,65 & 0,06 & 0,66 & 0,06 & & & \\
\hline \multirow{2}{*}{$\begin{array}{l}\text { Zināšanu } \\
\text { pārliecinātība }\end{array}$} & E. gr. & 0,76 & 0,11 & 0,85 & 0,08 & 0,01 & $5,40^{*}$ & $28,69^{* * *}$ \\
\hline & K. gr. & 0,82 & 0,07 & 0,79 & 0,10 & & & \\
\hline \multirow{2}{*}{$\begin{array}{l}\text { Spēju } \\
\text { pārvērtēšana }\end{array}$} & E. gr. & 0,07 & 0,07 & 0,04 & 0,08 & 0,03 & 3,17 & 0,06 \\
\hline & K. gr. & 0,07 & 0,06 & 0,05 & 0,06 & & & \\
\hline \multirow{2}{*}{$\begin{array}{l}\text { Spēju } \\
\text { pazemināšana }\end{array}$} & E. gr. & 0,37 & 0,16 & 0,42 & 0,14 & 0,06 & 1,08 & 3,00 \\
\hline & K. gr. & 0,39 & 0,12 & 0,38 & 0,12 & & & \\
\hline \multirow{2}{*}{$\begin{array}{l}\text { Soc_atbalsts } \\
\text { gimene }\end{array}$} & E. gr. & 8,40 & 2,66 & 7,63 & 3,68 & 0,12 & 0,85 & 1,21 \\
\hline & K. gr. & 7,70 & 3,50 & 7,76 & 3,72 & & & \\
\hline \multirow{2}{*}{$\begin{array}{l}\text { Soc_atbalsts } \\
\text { draugi }\end{array}$} & E. gr. & 7,13 & 3,98 & 7,50 & 3,91 & 2,88 & 3,18 & 0,90 \\
\hline & K. gr. & 4,86 & 5,79 & 6,06 & 4,23 & & & \\
\hline \multirow{2}{*}{$\begin{array}{l}\text { Soc_atbalsts } \\
\text { citi nozīmīgi } \\
\text { cilvēki }\end{array}$} & E. gr. & 9,36 & 3,12 & 9,20 & 3,17 & 3,79 & 0,15 & 0,66 \\
\hline & K. gr. & 7,43 & 4,33 & 7,90 & 3,41 & & & \\
\hline
\end{tabular}

$\left({ }^{a} \mathrm{df}=1 ; 58\right),{ }^{*} p<0,05,{ }^{* *} p<0,01,{ }^{* * *} p<0,001$

Iegūtie dispersijas rezultāti parāda, ka pastāv izmaiņas apmācību iekšgrupā starp atkārtotiem mērījumiem laikā. Statistiski nozīmīgi zināšanas starp pirms un pēc piedalīšanās programmā mērījumiem ir pieaugušas māšu zināšanu kopējā radītājā eksperimentālajai jeb apmācību grupai $\mathrm{F}(1,58)=9,05, \mathrm{p}<0,01$. Statistiski nozīmīgs pieaugums laikā tiek konstatēts arī eksperimentālajā grupā māšu zināšanu pārliecinātības rādītājā $\mathrm{F}(1,58)=5,40, \mathrm{p}<0,01$. Statistiskā nozīmība starp mērījumiem netiek konstatēta zināšanu precizitātes rādītājam, lai gan iegūtā vērtība ir salīdzinoši liela $-\mathrm{F}(1,58)=3.04, \mathrm{p}=0,08$.

Jauktās dispersiju analīzes rezultāti parādīja statistiski nozīmīgu grupas un laika mijiedarbības efektu apmācības grupas māšu norādītajiem zināšanu rādītājiem. Grupas un laika mijiedarbība parāda, ka grupām ir konstatējami atškirīigi izmaiṇu modeḷi 10 nedēlu jeb programmas norises laikā. Iegūtie rezultāti parāda, ka eksperimentālā grupa, atšķirībā no kontroles grupas, ir statistiski nozīmīgi pieaugusi zināšanu pārliecinātỉbas rādītājā $\mathrm{F}(1,58)=28,70, \mathrm{p}<0,001$. Tas parāda, ka apmācību grupā pēc piedalīšanās BEA programmā ir statistiski nozīmīgi uzlabojušies zināšanu pārliecinātībā, turpretī kontroles grupā zināšanu pārliecỉba ir salīdzinoši nemainīga jeb nav konstatējams uzlabojums (skat. 1. attēlu). 


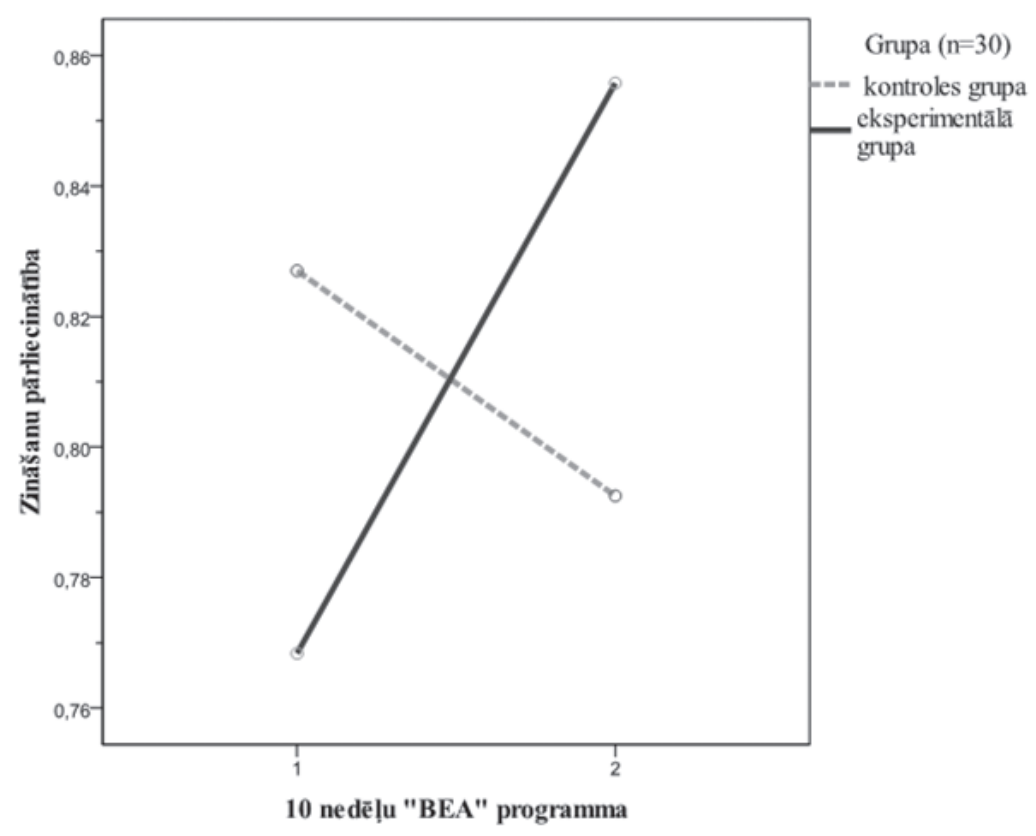

1. attēls. Zināšanu pārliecinātības izmaiņas eksperimentālajā un kontroles grupā pirms un pēc piedalī̌sanās BEA programmā

Statistiski nozīmīgs laika un grupas mijiedarbības efekts ir konstatējams arī eksperimentālās grupas kopējā zināšanu rādìtāja izmaiņās $\mathrm{F}(1,58)=16,96, \mathrm{p}<0,01$ (skat. 2. attēlu).

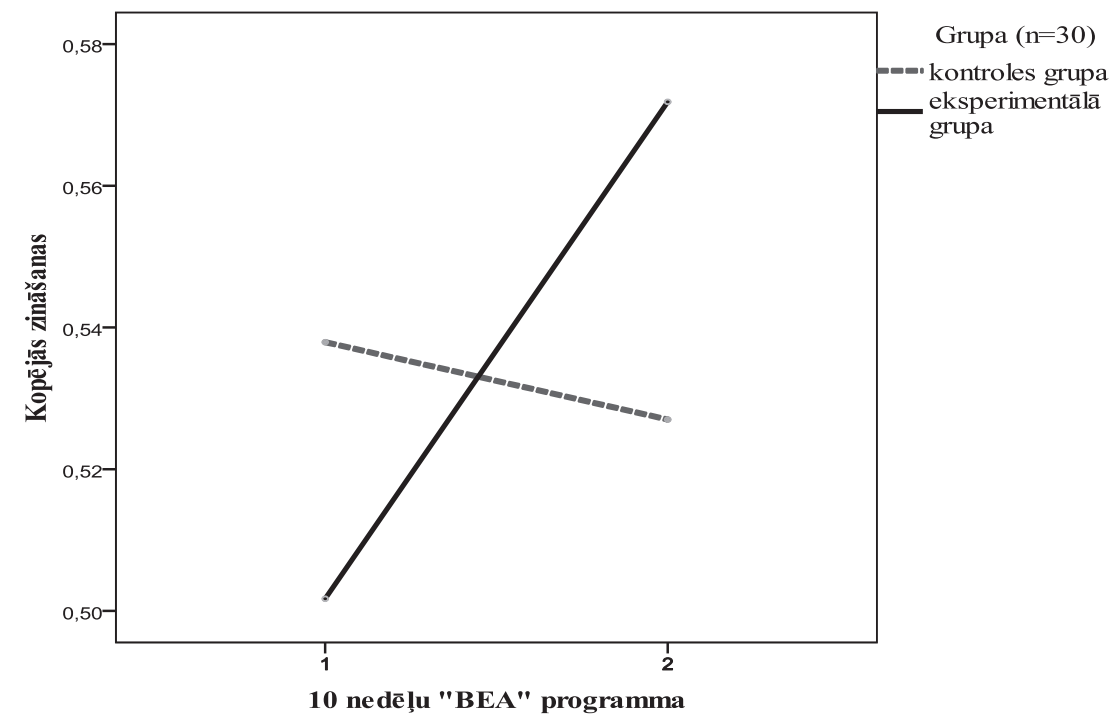

2. attēls. Kopējo zināšanu rādītāja izmaiṇas apmācību un kontroles grupā pirms un pēc piedalīšanās BEA programmā

2. attēlā redzams, ka grupas un laika mijiedarbībā - kontroles grupā zināšanu kopējā radītājā, salīdzinot ar sākotnējo mērỉjumu, ir samazinājusies, bet apmācību 
grupā programmas laikā kopējās zināšanas ir statistiski nozīmīgi pieaugušas, salīdzinot ar pirmo mērījumu. Faktoru laika un grupas mijiedarbībā netiek konstatētas statistiski nozīmīgas izmaiṇas zināšanu precizitātes rādītājā $F(1,58)=0,01, p<0,90$. Statistiski nozīmīgas atšķirības starp grupas un laika mijiedarbībā netiek konstatētas arī bērnu attīstības novērtējuma radītājos un izjustā sociālā atbalsta rādītājos. Analizējot iegūtos rezultātus, var secināt, ka pastāv statistiski nozīmīgas izmaiṇas kopējās zināšanās un zināšanu pārliecībā par bērna audzināšanu un attīstību mātēm pēc piedalī̌sanās "Bērnu emocionālās audzināšanas programmā". Vienlaikus netiek konstatētas statistiski nozīmīgas izjustā sociālā atbalsta izmaiṇas mātēm pēc piedalīšanās vecāku apmācību programmā.

Lai izslēgtu iespēju, ka pati grupa ietekmē rezultātu, tika noteiktas atškirīibas starp kontroles un apmācību grupu pirms un pēc mērījumu vidējiem lielumiem (skat. 2. tabulu). Iegūtie rezultāti parāda, ka nepastāv atškirīibas starp apmācību un kontroles grupu vidējiem rādītājiem zināšanās par bērna attīstību, audzināšanu un izjustā sociālā atbalsta rādītājiem. Tas norāda, ka grupai (apmācību vai kontroles) pašai par sevi nav ietekmes uz rezultātu, jo var novērtēt, ka izmaiṇas starp grupām notiek atšksirīgi jeb pretējā virzienā.

Lai varētu atbildēt uz pētījuma jautājumu, par to vai pastāv statistiski nozīmīga saistība starp izjustā sociālā atbalsta un zināšanu par bērna attīstību, audzināšanu rādītājiem pēc piedalīšanās "Bērnu emocionālās audzināšanas programmā", apmācību un kontroles grupā tika veikta Pīrsona korelācija (skat. 3. tabulu). Statistiski nozīmīga negatīva sakarība ir konstatējama starp bērna attīstības spēju pārvērtēšanas skalu un izjusto atbalstu no gimenes $(\mathrm{r}=-0,40, \mathrm{p}<0,05)$. Rezultāti parāda, ka izjūtot lielāku atbalstu no gimenes, ir vājāk izteikta bērnu spēju nepiemērota pārvērtēšana un otrādi, jo mazāks ir izjustais atbalsts no gimenes, jo vairāk māte pārvērtē bērna attīstības spējas. Pirmajā mērījumā netiek uzrādītas citas statistiski nozīmīgas sakarības starp izjusto atbalstu no draugiem vai nozīmīgiem cilvēkiem un uzrādītājām zināšanām par bērnu attīstību un audzināšanu. Var secināt, ka pastāv statiski nozīmīga pozitīva sakarība starp zināšanu par bērnu attīstību, audzināšanu precizitāti un izjusto sociālo atbalstu no gimenes $(\mathrm{r}=0,43, \mathrm{p}<0,05)$. Kā arī pastāv saistība starp zināšanu precizitāti un izjusto sociālo atbalstu no citiem nozīmīgiem cilvēkiem $(\mathrm{r}=0,38, \mathrm{p}<0,05)$. Tas nozīmē, ka jo lielāks ir izjustais atbalsts no gimenes un citiem nozīmīgiem cilvēkiem, jo vairāk precīzas jeb atbilstošas zināšanas tiek uzrādītas par bērnu audzināšanu un attīstību (skat. 3. tabulu).

3. tabula. Pīrsona korelācijas rādītāji zināšanām par bērna attīstību, audzināšanu un izjustajam sociālajam atbalstam apmācību grupā pirms un pēc piedalī̌anās programmā

\begin{tabular}{lcccccc}
\hline \multirow{2}{*}{ Mainīgie lielumi } & \multicolumn{2}{c}{$\begin{array}{c}\text { Sociälais atbalsts } \\
\text { gimene }\end{array}$} & \multicolumn{2}{c}{$\begin{array}{c}\text { Sociālais atbalsts } \\
\text { draugi }\end{array}$} & \multicolumn{2}{c}{$\begin{array}{c}\text { Sociālais atbalsts } \\
\text { citi nozimìgi cilvēki }\end{array}$} \\
\cline { 2 - 7 } & pirms & pēc & pirms & pēc & pirms & pēc \\
\hline Zināšanas kopā & 0,20 & 0,11 & 0,06 & $-0,10$ & 0,10 & 0,18 \\
Zināšanu precizitāte & 0,00 & $0,43^{*}$ & 0,14 & 0,16 & 0,20 & $0,38^{*}$ \\
Zināšanu pārliecinātība & $-0,19$ & $-0,25$ & $-0,07$ & $-0,24$ & $-0,10$ & $-0,14$ \\
Spēju pārvērtēšana & $-0,40^{*}$ & $-0,32$ & $-0,29$ & $-0,14$ & $-0,34$ & $-0,34$ \\
Spēju pazemināšana & 0,12 & $-0,11$ & 0,34 & $-0,00$ & 0,25 & 0,40 \\
\hline
\end{tabular}

$n=30,{ }^{*} p<0,05$ 
Kontroles grupas pirmajā mērījumā pastāv statistiski nozīmīga sakarība starp izjusto sociālo atbalstu no draugiem un zināšanu precizitāti par bērna attīstību un audzināšanu $(\mathrm{r}=0,39, \mathrm{p}<0,05)$. Tas parāda, ka palielinoties izjustajam atbalstam no draugiem, lielāka ir iegūto zināšanu precizitāte un pretēji - palielinoties zināšanu precizitātei tiek uzrādīts lielāks izjustais atbalsts no draugiem. Pīrsona korelācijas rezultāti norāda, ka kontroles grupā pēc 2. mērījuma nav konstatējamas statistiski nozīmīgas sakarības starp izjustā sociālā atbalsta un zināšanu par bērna attīstību mainīgajiem lielumiem (sk. 4. tabulu).

4. tabula. Pīrsona korelācijas rādītāji zināšanām par bērna attīstību, audzināšanu un izjustajam sociālajam atbalstam kontroles grupā pirms un pēc mērỉjumiem

\begin{tabular}{lcccccc}
\hline \multirow{2}{*}{ Mainīgie lielumi } & \multicolumn{2}{c}{$\begin{array}{c}\text { Sociālais atbalsts } \\
\text { gimene }\end{array}$} & \multicolumn{2}{c}{$\begin{array}{c}\text { Sociālais atbalsts } \\
\text { draugi }\end{array}$} & \multicolumn{2}{c}{$\begin{array}{c}\text { Sociälais atbalsts } \\
\text { citi nozìmīgi cilvēki }\end{array}$} \\
\cline { 2 - 7 } & pirms & pēc & pirms & pēc & pirms & pēc \\
\hline Zināšanas kopā & 0,07 & 0,03 & 0,13 & 0,07 & 0,14 & $-0,02$ \\
Zināšanu precizitāte & 0,10 & 0,11 & $0,39^{*}$ & 0,30 & 0,10 & $-0,13$ \\
Zināšanu pārliecinātība & 0,00 & $-0,03$ & $-0,24$ & 0,10 & 0,05 & 0,05 \\
Spēju pārvērtēšana & $-0,10$ & $-0,14$ & $-0,33$ & $-0,24$ & $-0,08$ & $-0,15$ \\
Spēju pazemināšana & $-0,00$ & $-0,01$ & 0,08 & 0,15 & $-0,15$ & $-0,11$ \\
\hline
\end{tabular}

$n=30,{ }^{*} p<0,05$

\section{Diskusija}

Iegūtie rezultāti parāda, ka pēc piedalīšanās programmā pastāv statistiski nozīmīgas izmaiṇas māšu kopējās zināšanās par normatīvu jeb tipisku bērna attīstību un audzināšanu, kā arī mātes kopumā ir kḷuvušas pārliecinātākas par savām zināšanām. Vienlaikus pēc piedalīšanās apmācību programmā netiek konstatēts jaunu, specifisku zināšanu par bērna attīstību un audzināšanu pieaugums un nav statistiski nozīmīgi samazinājusies bērna attīstības spēju pārvērtēšana vai pazemināšana. Statistiski nozīmīgas izmaiṇas pēc piedalī̌̌anās programmā netiek konstatētas arī māšu izjustajā sociālajā atbalstā no ǵimenes, draugiem un citiem nozīmīgiem cilvēkiem. Pēc piedalīšanās apmācību programmā ir konstatējama statistiski nozīmīga pozitīva sakarība starp māšu uzrādīto zināšanu atbilstību jeb precizitāti par normatīvu bērna attīstību, audzināšanu un izjusto atbalstu no gimenes un citiem nozīmīgiem cilvēkiem.

Šì pētījuma rezultāti saskan ar iepriekšējo pētījumu rezultātiem, kas parāda, ka piedaloties apmācības vai intervences programmās uzlabojas māšu zināšanas par bērna attīstību un audzināšanu (Landy \& Thompson, 2006; MacPhee, 2002; MacPhee \& MillerHeyl, 2006, Winter, Morawska, \& Sanders, 2012). "Bērnu emocionālās audzināšanas" programmas autores Lendijas un Tompsones pētijumā, kurā tika izmantots šis pats zināšanu mērinstruments tika konstatēts, ka, tāpat kā šajā pētījumā, statistiski nozīmīgs pieaugums zināšanās mērījumā pēc piedalīšanās programmā. Līdzīgi arī kā šajā pētījumā, kontroles grupa laika periodā starp pirmo un otro mērījumu uzrādīja zināšanu pazemināšanos (Landy \& Thompson, 2006). Šie atklājumi atbilst arī iepriekšējiem pierādījumiem par to, ka KIDI - P aptaujas zināšanas ir sensitīvas attiecībā uz formālu vai akadēmisku intervenci. Pēc 12 nedēḷu garas vecāku izglìtības programmas "Head Start” tika uzradīts nozīmīgs pieaugums kopējās zināšanās un īpaši vecāku pārliecinātībā 
par savām zināšanām. Līdzīgi kā šajā pētījumā, zināšanu precizitāte palika nemainīgi stabila jeb ar statistiski nenozīmīgām izmaiṇām abās grupās (MacPhee, 2002). KIDI $\mathrm{P}$ aptaujas rokasgrāmatā ir apkopoti dati no vairākiem pētījumiem, kur mērītas zināšanu uzlabojums pēc vecāku piedalī̌anās dažādās programmās, kas arī parāda ierobežojumus pētniecībai šajā jomā, jo programmās bieži iztrūkst sākotnējā mērījuma vai kontroles grupas, kā arī līdzīgi kā šajā pētījumā izlases ir salīdzinoši nelielas vai arī netiek konstatētas nozīmīgas izmaiṇas zināšanās (Bacharach, 1997; Wagner \& Clayton, 1999, kā minēts MacPhee, 2002). Tiek secināts, ka, galvenokārt, zināšanu uzlabojums ir konstatējams intervences programmās, kur notiek intensīva apmācība par bērna attīstības normām un principiem daudz vairāk, nekā programmās, kur galvenais fokuss ir bērnu audzināšanas un aprūpes prasmes (MacPhee, 2002). Iespējams, tas var izskaidrot BEA efektivitāti apmācības grupas kopējo zināšanu un zināšanu pārliecības uzlabošanā, jo programmā notiek māšu izglītošana par bērna attīstības normām un principiem dažādos vecumposmos un dažādās attīstības jomās.

Īpaši nozīmīgs pieaugums laikā tika konstatēts apmācību jeb eksperimentālās grupas zināšanu pārliecinātībā. Tas parāda, ka pētījuma dalībnieki pēc piedalī̌sanās apmācības programmā ir jutušies vairāk kompetenti atbildot uz tiem aptaujas jautājumiem, par ko iepriekš šaubỉjās un lietoja "neesmu pārliecināts" atbildi. Iepriekšèjās pētījumos par bērnu attīstības zināšanu saistību ar vecāku pašefektivitātes mērījumiem, tika konstatēta statistiski nozīmīga sakarība starp zināšanu pārliecinātības rādītāju un pašefektivitāti, vienlaikus netika konstatēta saistība ar zināšanu precizitāti. Šie secinājumi var tikt balstīti uz argumentu, ka šis KIDI- P rādītājs atspoguḷo mātes pašpārliecību un pašpal̦āvīgumu uz savām zināšanām (MacPhee, 2002; MacPhee \& Miller-Heyl, 2006). Tas saskan arī ar Latvijā veikto pētījumu, kurā pēc piedalǐšanās "Bērnu emocionālās audzināšanas programmā” paaugstinājās jeb pieauga mātes kompetences izjūta un sava efektivitāte mātes lomā, kā arī tika mazāk norādītas bērna internalizētas un eksternalizētas uzvedības problēmas, nekā pirms piedalǐšanās programmā (Skreitule-Pikše, 2010). Saskaṇā ar Banduras pašefektivitātes teoriju (Bandura, 1977, 1986, 1989, kā minēts Conrad et al., 1992) indivīda uzvedības sniegums tiek ietekmēts caur kombinētu efektu, ko rada indivīda zināšanas par uzdevumu, šajā gadījumā mātes zināšanas par bērna attīstību un audzināšanu, un viņa pārliecība par spējām paveikt šo uzdevumu veiksmīgi. Uzdevuma veiksmīgai paveikšanai ir specifiskas un precīzas zināšanas par uzvedībām, kas nepieciešamas, lai veiksmīgi sasniegtu mērḳi. Mātei ne tikai ir nepieciešama pārliecība par spējām būt labam vecākam, bet arī specifiskas zināšanas par uzvedību, kas nepieciešama, lai atbilstoši interpretētu un reaǵētu uz bērna vajadzībām, zināšanas par bērna normatīvu attīstību un attīstības posmiem un zināšanas par to kādi faktori ietekmē bērna attīstību (Hess, et al., 2004). Veiktajos pētījumos par mātes - bērna mijiedarbības saistību ar mātes pašpārliecību un zināšanām parādīja, ka mātes mijiedarbība ar bērnu bija visvairāk pozitīva māšu grupā, kur uzrādīja visaugstākās zināšanas par bērnu attīstību un bija salīdzinoši visvairāk pārliecinātas. Vienlaikus mātes pašpārliecība bija nozīmīga saistīta ar vecāka - bērna mijiedarbību, pie nosacījuma, ka tika ņemtas vērā mātes zināšanas (Contrad, et al., 1992, Hess, et al., 2004). Tas l̦auj secināt, ka zināšanas iespējami kalpo kā mediators mātes mijiedarbībā ar bērnu, kas tālāk attiecīgi samazina vai palielina bērna uzvedības problēmas un iezīmē nākotnes perspektīvu 
un nepieciešamo pētniecisko virzību Latvijā saistībā ar vecāku apmācības programmu "Bērnu emocionālā audzināšana".

Pēc piedalǐšanās programmā šajā pētījumā netika konstatētas statistiski nozīmīgas izmaiṇas izjustajā sociālajā atbalstā, kas iespējams skaidrojams ar to, ka mātes nāk no vidēji sociāli ekonomiskā slāṇa, vairāk nekā puse no dalībniecēm ir augstāko vai nepabeigtu augstāko izglītību un novērtē savu ğimeni kā materiāli nodrošinātu. Iespējams, ka vidēji eksperimentālajā grupā mātes izjūt un māk saṇemt atbilstošu atbalstu gan no gimenes, draugiem un citiem nozīmīgiem cilvēkiem. Iespējams, atšķirīgi rezultāti pēc BEA programmas būtu sagaidāmi mātēm ar zemu izglìtības līmeni un zemiem materiālās labklājības rādītājiem. Kā tas tika konstatēts Kanādā veiktajā šīs programmas pētījumā, kur tika konstatētas atšķirības izjustajā atbalstā pēc piedalīšanās programmā, salīdzinot ar kontrolgrupu (Landy, \& Thompson, 2006). Vēl viens potenciāli iespējamais skaidrojums ir, ka apmācỉbas grupa pati par sevi, lai gan netieši, veicina sociālo prasmju attīstī̌sanu komunikācijā, nav piemērota intervence izjustā sociālā atbalsta izmaiṇām vai arī tas ir vairāk saistāms ar demogrāfiskajiem faktoriem nevis intervenci paši par sevi. Kā arī, iespējams, "Izjustā sociālā atbalsta" aptauja nav piemērots instruments, ka šajā apmācības situācijā, atspoguḷotu mātes dzīves kvalitātēs uzlabojumu. Iespējams izmaiņas izjustajā sociālajā atbalstā tiku konstatētas, ja abi vecāki no giimenes piedalìtos "Bērnu emocionālās audzināšanas” programmā.

Vienlaikus māšu apmācības grupā pēc piedalīšanās programmā tiek konstatēta sakarība starp zināšanu precizitāti par tipisku jeb normatīvu bērna attīstību un izjusto sociālo atbalstu no ğimenes un citiem nozīmīgiem cilvēkiem. Kā parāda pētījumi, izjustais sociālais atbalsts ir nozīmīgs aspekts veidojot bērnu audzināšanas kvalitāti, vecāku atsaucību uz bērna vajadzībām un zemākiem riskiem attiecībā uz vecāka fiziku agresiju pret bērnu un palielinātu vecāka pašefektivitāti (Molnar, Buka, Brennan, Holton, \& Earls, 2003; Anderesen \& Tellen, kā minēts Koenen et al., 2012). Konstatētā sakarība parāda, ka mātes ar precīzākām zināšanām par bērnu audzināšanu un attīstību izjūt proporcionāli vairāk atbalsta, ko iespējams skaidrot gan ar grupas sociāli demogrāfiskajiem rādītājiem un izglītības līmeni. Gan arī ar "BEA” programmas iespējamu ietekmi attiecībā uz mātes kognīcijām, tieši atribūcijām gan bērna, gan citu tuvu cilvēku uzvedības interpretācijā. Jāṇem vērā, ka BEA grupa vecākiem uz kopēju interešu un grūtību pamata darbojas arī kā atbalsta grupa un iespējams, ka ar "citiem nozīmīgiem cilvēkiem” tiek norādīts izjustais atbalsts no grupas dalībniekiem.

Novērtējot šì pētījuma stiprās un vājās puses, var secināt, ka viens no ierobežojumiem ir pētījuma izlases apjoms, kas ir salīdzinoši neliels un pilnībā neatspoguḷo pirmsskolas vecuma bērnu māšu zināšanu līmeni. Kā vēl viens pētījuma ierobežojums ir aplūkojams izlases vecums, ka ir izliedēts un variē starp gados jaunākām un gados vecākām mātēm, vienlaikus iepriekšējo pētijumu rezultāti norāda, ka pastāv atšḳirības zināšanās starp gados jaunākām un vecākām mātēm. Diskutabls ir jautājums par BEA grupas vadītāju pieredzes ietekmi uz apmācības grupas dalībnieku uzrādītajām zināšanām, iespējams, pirmā pieredze un atškiirīgs vadītāju vecums var radīt atškirīgus rezultātus kopējās zināšanās un zināšanu pārliecībā starp apmācības grupām. Pētījumā ir vairāki nekontrolēti mainīgie lielumi, kas var ietekmēt zināšanu un izjustā sociālā atbalsta 
sniegumu, piemēram, vecāka pašefektivitāte, apmierinātība ar partnerattiecībām, mātes izglìības joma un darbavieta, bērna raksturojums un uzvedības grūtības utt.

Kā arī netiek atseviškịi analizētas un statistiski novērtētas "Bērnu emocionālās audzināšanas” programmas dimensijas, kā, piemēram, vecāku iesaistīšanās, apmeklējuma intensitāte, mājas darbu pildīšana. Nākotnes perspektīvā būtu svarīgi arī izprast, kuri programmas aspekti vai soḷi iedarbojas specifiski uz zināšanām par tipisku jeb normatīvu bērna attīstību un kāda veida apmācība strukturēšana būtu nepieciešama, lai palielinātu vecāku precizitāti par bērna attīstības spējām.

Šis pētījums paver iespējas veikt turpmāko pētniecību zināšanu par bērna attīstību un audzināšanu jomā dažāda lieluma un vecuma vecāku grupās. Nepieciešams izpētīt arī Latvijas māšu zināšanu par bērna attīstību, audzināšanu un kompetences izjūtas nozīmi mātes mijiedarbībā ar bērnu. Būtu svarīgi veikt pētījumus par māšu no sociālā riska grupas piedalī̌̌anos apmācības programmā un iegūto zināšanu uzlabojumu, jo kā parāda līdzīga dizaina iepriekšèjie pētījumi, visi vecāki iegūst no vecāku apmācības programmām, bet īpaši uzlabojas zināšanas vecākiem no sociālā riska grupām. Pētījums ir praktiski izmantojams, kā pamatojums pašvaldības vai valsts apmaksātam "Bērnu emocionālās programmas” pakalpojumam vecākiem no sociālā riska grupām.

Kopumā veiktais pētījums ir nozīmīgs vairākos aspektos:

1. Zinātniski pierāda, ka mātes pēc piedalī̌̌anās "Bērnu emocionālās audzināšanas programmā”, salīdzinot ar sākotnējo mērījumu, uzrāda lielākas kopējās zināšanas par bērna attīstību un audzināšanu un pauž lielāku pārliecinātību par savām zināšanām.

2. Šis pētījums paplašina pētniecību saistībā ar "Bērnu emocionālās audzināšanas" programmas efektivitāti attiecībā uz vecāku zināšanu palielināšanu par bērnu audzināšanu un attīstību, jo līdz šim Latvijā ir veikts tikai viens pētījums saistībā ar "BEA" programmu (Skreitule-Pikše, 2010).

3. Pētījums praktiski izmantojams, kā pamatojums pašvaldības vai valsts apmaksātam "Bērnu emocionālās programmas" pakalpojumam vecākiem no sociālā riska grupām.

\section{Izmantotā literatūra}

American Psychological Association. (2009). Effective strategies to support positive parenting in community health centres: Report of the working group on child maltreatment prevention incommunity health centres. Washington, DC: American Psycho-logical Association.

Azar, S. T., \& Twentyman, C. T. (1984). An evaluation of the effectiveness of behaviorally versus insight oriented group treatments with maltreating mothers. Paper presented at the annual meeting of the Association for Advancement of Behavior Therapy. Philadelphia.

Bandura, A. (1997). Self-efficacy: The exercise of control, New York: Freeman.

Barbour, N., Richardson, \& R, Bubenzer, D. (1995). Adolescent mothers and parenting stress: Comparisons with normative and later age mothers. Paper presented at the Biennial Society for Research in Child Development Meeting, Indianapolis, Indiana. 
Barlow, J., \& Parsons, J. (2003). Group-based parent-training programmes for improving emotionaland behavioural adjustment in 0-3 year old children. Cochrane Database of Systematic Reviews 2. Art. No.: CD003680, DOI: 10.1002/14651858.

Barlow, J., Coren, E., \& Brown, S. S. (2003). Parent-training programmes for improving maternal psychosocial health. Cochrane Database of Systematic Reviews 2003, Issue 4. Art. No.: CD002020, DOI: 10.1002/14651858.CD002020.pub2.

Bell, R.(1979). Parent, child, and reciprocal influences. American Psychologist, 34, 821-826.

Belsky, J. (1984). The determinants of parenting. Child Development, 55, 83-96.

Belsky, J., \& Isabella, R. (1988). Maternal, infant and social-contextual determinants of attachment security. In Belsky, J. \& Nezworski, T. (Eds.), Clinical implications of attachment. (p. 41-94). NJ: Hillsdale: Lawrence Erlbaum Associates.

Belsky, J. (1990). Parental and nonparental child care and children's socioemotional development: A decade in review. Journal of Marriage and the Family, 52, 885-903.

Benasich, A. A., \& Brooks-Gunn, J. (1996). Maternal attitudes and knowledge of child-rearing: Associations with family and child outcomes. Child Development, 67, 1186-1205.

Bornstein, M. H. (2006). Parenting science and practice. In K. A. Renninger, I. E. Sigel, W. Damon, \& R. M. Lerner (Eds.), Handbook of child psychology: Vol. 4. Child psychology in practice (6 ${ }^{\text {th }}$ ed., pp. 893-949). Hoboken, NJ: Wiley.

Bornstein, M. H., Cote, L. R., Haynes, M. O., Hahn C. S., \& Park, Y. (2010). Parenting Knowledge: Experiential and Sociodemographic Factors in European American Mothers of Young Children. Developmental Psychology, 10, 1-17.

Bornstein, M. H., Putnick, D. L., Suwalsky, J. T. D., \& Gini, M. (2006). Maternal Chronological Age, Prenatal and Perinatal History, Social Support, and Parenting of Infants. Child Development, 77 (4), 875-892.

Bravo, M., Canino, G. J., Rubio-Stipec, M., and Serrano-García, I. (1991). Importancia de la familia como recurso de apoyo social en Puerto Rico. PRHS, 10, 149-156.

Buchholz, E, \& Korn-Bursztyn, C. (1993). Children of adolescent mothers: Are they at risk for abuse? Adolescence, 28, 361-82.

Bugental, D. B., \& Happaney, K. (2002). Parental attributions. In M. Bornstein (Ed.), Handbook of parenting Vol. 3: Being and becoming a parent (pp. 509-535). Hillsdale, NJ: Erlbaum.

Chaffin, M., Silovsky, J. F., Funderburk, B., Valle, L. A., Brestan, E. V., \& Balachov. (2004). Parent-child interaction therapy with physically abusive parents: Efficacy for reducing future abuse reports. Journal of Consulting and Clinical Psychology, 72(3), 500-510.

Cobb, S. (1976). Social support as a moderator of life stress. Psychosomatic Medicine, 38, 300-314.

Cochran, M. (1990). Personal social networks as a focus of support. Prevention in Human Services, 9, 45-67.

Cochran, M., \& Niego, S. (2002). Parenting and social networks. In M. H. Bornstein (Ed.), Handbook of parenting: Vol. 4. Applied parenting (2 ${ }^{\text {nd }}$ ed., pp. 123-148). Mahwah, NJ: Erlbaum.

Cohen, S., \& Wills, T. A. (1985). Stress, social support, and the buffering hypothesis. Psychological Bulletin, 98, 310-357.

Collins, W. A., Maccoby, E. E., Steinberg, L., Hetherington, E. M., \& Bornstein, M. H. (2000). Contemporary research on parenting: The case for nature and nurture. American Psychologist, $55,218-232$. 
Conrad, B., Gross, D., Fogg, L., \& Ruchala, P. (1992). Maternal confidence, knowledge, and quality of mother-toddler interactions: A preliminary study. Infant Mental Health Journal, 13, 353-362.

Cowen, P. S (2001). Effectiveness of a parent education intervention for at-risk families. Journal for Specialists in Pediatric Nursing, 6,73-82.

Crnic K., \& Low C. (2002) Everyday stresses and parenting. In: Bornstein MH, editor. Handbook of parenting: Vol. 5: practical issues in parenting, (pp. 243-267), NJ: Erlbaum.

Crockenberg, S. (1988). Social support and parenting. In H. E. Fitzgerald, B. M. Lester, \& M. W. Yogman (Eds.). Theory and research in behavioral pediatrics, Vol. 4., (pp. 141-174), New York: Plenum Press.

Culp, A. M., Culp, R. E., Blankemeyer, M., \& Passmark, L. C. (1998). Parent education home visitation program: Adolescent and older mothers comparison after six months of intervention. Infant Mental Health Journal, 19, 111-123.

Cutrona, C. E., \& Suhr, J. A. (1990). The transition to parenthood and the importance of social support. In S. Fisher \& C. L. Cooper (Eds.), On the move: The psychology of change and transition (pp. 111-125). New York: Wiley.

Depner, C. E., Wethington, E., \& Ingersoll-Dayton, B. (1984). Social support: Methodological issues in design and measurement. Journal of Social Issues, 40, 37-54.

Dichtelmiller, M., Meisels, S. M., Plunnkett, J. W., Bozynsky, M. E., Clafin, C., \& Mangelsdorf, S. C. (1992). The relationship of parental knowledge to the development of extremely low birth weight infants. Journal of Early Intervention, 16 (3), 210-220.

Dix, T., \& Grusec, J. E. (1985). Parent attribution processes in child socialization. In I. Sigel (Ed.), Parental belief systems: The psychological consequences for children (pp. 201-233). Hills-dale, NJ: Erlbaum.

Engle, P. L., \& Ricciuti, H. N. (1995). Psychosocial aspects of care and nutrition. Food and Nutrition Bulletin Supplement, 16 (4), 356-377.

Field, T. M., Widmayer, S. M., Stringer, S., \& Ignatoff, E. (1980). Teenage, lower-class, Black mothers and their preterm infants: An intervention and developmental follow-up. Child Development, 51, 426-436.

Gardner, F., Connell, A., Trentacosta, C. J., Shaw, D. S., Dishion, T. J., \& Wilson, M. N. (2009). Moderators of outcome in a brief family-centered intervention for preventing early problem behavior. Journal of Consulting and Clinical Psychology, 77, 543-553.

Garrett S., \& Tidwell, R. (1999). Differences between adolescent mothers and non-mothers: An interview study. Adolescence, 34, 91-105.

Goodnow, J. J. (2002). Parents' knowledge and expectations: using what we know. In Bornstein, M. H. (Ed.), Handbook of Parenting, Being and Becoming a Parent, Vol. 3., (pp. 439-460). Mahwah, New Jersey, Lawrence Erlbaum Associates, Inc.

Goodnow, J. J., Cashmore, J., Cotton, S., \& Knight, R. (1984). Mothers' developmental timetablesin two cultural groups. International Journal of Psychology, 19, 193-205.

Goodnow, J. J., \& Collins, W. A. (1990). Development according to parents: The nature, sources, and consequences of parents' ideas. London, England: Erlbaum.

Goodnow, J. J., Miller P. J., \& Kessel K. (Eds.). (1995). Cultural practices as contexts for development. New Directions for Child Development. San Francisco: Jossey-Bass.

Gottlieb, B. H. (1985). Assessing and strengthening the impact of social support on mental health. Social Work, 30, 293-300. 
Grusec, J. E., Rudy, D., \& Martini, T. (1997). Parenting cognitions and child outcomes: An overview and implicationsfor children's internalization of values. In Grusec, J. E., \& Kuczynski, L. (Eds.), Parenting strategies and children's internalization of values (pp. 259-282). New York: Wiley.

Hammond-Ratzlaff, A., \& Fulton, A. (2001). Knowledge gained by mothers enrolled in a home visitation program. Adolescence, 36, 435-442.

Hess, R. D., Kashiwagi, K., Azuma, H., Price, G. G., \& Dickson, W. P. (1984). Maternal expectations for mastery of developmental tasks in Japan and the United States. International Journal of Psychology, 15, 259-271.

Hess, R. C., Tetib, D. M., \& Hussey-Gardnerc, B.(2004). Self-efficacy and parenting of highrisk nfants: The moderating role of parent knowledge of infant development. Applied Developmental Psychology, 25, 423-437.

Hoff, E., Laursen, B., \& Tardif, T. (2002). Socioeconomic Status and Parenting, Bornstein, M. H. (Ed). Handbook of Parenting, Biology and ecology of parenting, Vol. 2. (pp. 231-252). Mahwah, New Jersey, Lawrence Erlbaum Associates, Inc.

Hunt, J. M., Paraskevopoulos, J. (1980). Children's psychological development as a function of the inaccuracy of their mothers' knowledge of their abilities. The Journal of Genetic Psychology, 136, 285-298.

Landy, S. (2002). Pathways to competence: encouraging healthy social and emotional development in young children. Baltimore: Paul H. Brookes Publishing Co.

Lendija, S. \& Ozola, E. (2004). Bērna emocionālā audzināšana. Vecāku apmācības programma. Rokasgrāmata grupu vadītājiem. Rīga: Apgāds "Rasa ABC.

Letourneau, N. L., Miriam, R. N., Stewart, M. J., \& Barnfather, A. K. (2004). Adolescent mothers: Support needs, resources, and support-education interventions. Journal of Adolescent Health, 35, 509-525.

Lundahl, B. W., Nimer, J., \& Parsons, B. (2006). Preventing child abuse: a meta-analysis of parent training programs. Research on Social Work Practice, 16, 251-262.

MacPhee, D. (1983). The nature of parents' experiences with and knowledge about infant development In I. Sigel (Chair), The cognitive experience of parents: The study and implications of parental knowledge, perceptions, reasoning, and beliefs. Symposium conducted at the biennial meeting of the Society for Research on Child Development, Detroit.

MacPhee, D. (1981, revised 2002). Manual for the Knowledge of Infant Development Inventory, Survey of Child Care Expierences. Unpublished manuscript. University of North Carolina.

MacPhee, D., \& Miller-Heyl, J. (2006). Head Start - University Partnership Grant DARE to BE YOU Project. Final evalution Report.

McGillicuddy-DeLisi, A. B. (1982a). Parental beliefs about developmental processes. Human Development, 25, 192-200.

McGillicuddy-DeLisi, A. B. (1982b). The relationship between parental beliefs and children's cognitive development. In L. M. Laosa \& I. E. Sigel (Eds.), Families as learning environments for children (pp. 7-24). New York, NY: Plenum.

Molnar, B. E., Buka S. L., Brennan, R. T., Holton, J. K., Earls, F. (2003) A multilevel study of neighborhoods and parent-to-child physical aggression: results from the project on human development in Chicago neighborhoods. Child Maltreatment 8: 84-97. 
Morawska, A, Winter, L., \& Sanders, M. R. (2009). Parenting knowledge and its role in the prediction of dysfunctional parenting and disruptive child behaviour. Child: Care, Health and Development, 35 (2) 217-226.

Murphey, D. A. (1992). Constructing the Child: Relations between Parents: Beliefs and Child Outcomes. Developmental review, 12, 199-232.

Newby-Fraser, E. and Schlebusch, L. (1997). Social support, self-efficacy and assertiveness as mediators of student stress. Psychology: A Journal of Human Behavior, 34, 61-69.

Nichols, S., Nixon, H., Pudney, V., \& Jurvansuu, S. (2009). Parents resourcing children's early development and learning. Early Years, 29 (2), 147-161.

Ninio, A. (1988). The naive theory of the infant and other maternal attitudes in two subgroups in Israel. Child Development, 50, 976-980.

Nix, R. L., Bierman, K. L., \& McMahon, R. J. (2009). How attendance and quality of participation affect treatment response to parent management training. Journal of Consulting and Clinical Psychology, 77, 429-438.

Page, M. A. (2008). The context and expierence of new mothers: Postpartum depression, family relationships, knowledge of infant development, and infant outcomes. The University of Arizona, dissertation (unpublished).

Peterson, L., Tremblay, G., Ewigman, B., \& Saldana, L. (2003). Multilevel Selected Primary Prevention of Child Maltreatment, Journal of Consulting and Clinical Psychology, 71 (3), 601-612.

Reich, S. (2005). What do mothers know? Maternal knowledge of child development. Infant Mental Health Journal, 26 (2), 143-156.

Rikhy, S., Tough, S., Trute, B., Benzies, K., Kehler, H., \& Johnston, D. W. (2010). Gauging knowledge of developmental milestones among Albertan adults: a cross-sectional survey, BMC Public Health, 10 (183), 1-9.

Riksen-Walraven, J. M., \& van Bakel, H. J. A. (2002). Parenting and development of one-yearolds: links with parental, contextual, and child characteristics. Child Development, 73 (1), 256-273.

Rutter, M. (1979). Protective factors in children's messages to stress and disadvantage. In M. W. Kent and J. E. Rolf (Eds.), Primary Prevention of Psychopathology, Vol. 3: Social Competence in Children. (p. 49-74). Hanover, NH: University Press of New England.

Sanders, M. R., \& Morawska, A. (2005). Can changing parental knowledge, dysfunctional expectations and attributions, and emotion regulation improve outcomes for children? In Tremblay, Ronald, R. E., Barr, E., \& Peters, R. V., (Ed.), Encyclopedia on early childhood development 1 ed. (pp. 1-12) Montreal, Quebec: Centre of Excellence of Early Childhood Development.

Simons, R. L., \& Johnson, C. (1996). The impact of marital and social network support on quality of parenting. In G. R. Pierce, B. R. Sarason, \& I. C. Sarason (Eds.), Handbook of social support and the family (pp. 269-288). New York: Plenum.

Simons, R. L., Lorenz, F. O., Wu, C., \& Conger, R. D. (1993). Social network and marital support as mediators and moderators of the impact of stress and depression on parental behavior. Developmental Psychology, 29, 368-381.

Simons, R. L., Whitbeck, L. B., Conger, R. D., \& Melby, J. N. (1990). Husband and wife differences in determinants of parenting: A social learning/exchange model of parental behavior. Journal of Marriage and the Family, 52, 375-392. 
Skreitule-Pikše I. (2010). Mātes kometences izjūtas, mātes - bērna emocionālās pieejamības un bèrna uzvedības izmaiņas pèc mātes piedalīšanās vecāku mācību programmā "Bèrna emocionālā audzināšana”. Rīga (nepublicēts materiāls).

Stevens, J. H. (1984). Child development knowledge and parenting skills. Family Relations 33, 237-244.

Stewart, M. (2000). Chronic Conditions and Caregiving in Canada: Social Support Strategies. Toronto: University of Toronto Press.

Stewart, M. (1993). Integrating Social Support in Nursing. New York, NY: Sage.

Stolk, M. N., Mesman, J., van Zeijl, J., Alink, R. A., Bakermans-Kranenburg, M., van IJzendorn, M. H., Juffer, F., \& Koot, H. M. (2007). Early parenting intervention: family risk and first - time parenting related to intervention effectiveness. Journal of Child \& Family Studies, 17, 55-83.

Taylor, L. C., Clayton, J. D., \& Rowley, S. J. (2001). Academic socialization: Understanding parental influences on children's school-related development in the early years. Review of General Psychology, 8, 163-178.

Thoits, P. A. (1982). Conceptual, methodological, and theoretical problems in studying social support as a buffer against life stress. Journal of Health and Social Behavior, 23, 145-159.

Todd, L. 2003. Disability and the restructuring of welfare: The problem of partnership with parents. International Journal of Inclusive Education 7, no. 3: 281-96.

Trentacosta, C. J., Neppl, T. K., Donnellan, B. M., Scaramella, L. V., Shaw, D. S., \& Conger, R. D. (2010). Adolescent personality as a prospective predictor of parenting: an interactionist perspective. Journal of Family Psychology, 24 (6), 721-730.

Twentyman, C. T, \& Plotkin R. C. (1982). Unrealistic expectations of parents who maltreat their children: An educational deficit that pertains to child development. Journal of Clinical Psychology, 38, 497-503.

Ukstiņa, A. (2011.) Zināšanas par bērna attīstību, audzināšanu un sociālais atbalsts dažāda vecuma mātēm (nepublicēts materiāls).

Vaux, A. (1988). Social and emotional loneliness: The role of social and personal charasteristics. Personality and Social Psychology Bulletin, 14, 722-734.

Watson, J., White, A., Taplin, S., \& Huntsman L. S. S. (2005). Prevention and early intervention literature review. NSW Centre for Parenting and Research, Department of Community Services.

Williams, P. D., Williams, A. R.. Lopez, M, Tayko, N. P. (2000). Mothers' developmental expectations for young - children in the Philippines. International Journal of Nursing Studies, 37(4), 291-301.

Winter, L., Morawska, A., \& Sanders M. R. (2012). The effect of behavioral family intervention on knowledge of effective parenting strategies. Child Family Studies, 21, 881-890.

Zepeda, M., Varela, F., Morales, A. (2004). Promoting positive parenting practices through parenting education. In: Halfon, N., Rice T., \& Inkelas, M., eds. Building State Early Childhood Comprehensive Systems Series, 13. National Center for Infant and Early Childhood Health Policy. 


\title{
Ģimenes locekḷa alkohola atkarības pieredzes bērnībā, uzvedības īpatnības, stresa pārvarēšanas stratēgijas un traumatiskā pagātnes pieredze
}

\author{
Iveta Damroze un Laura Pirsko ${ }^{1}$
}

Latvijas Universitāte

\begin{abstract}
Abstrakts
Pētījuma mērḳis bija noskaidrot, vai traumatiska pagātnes un ǵimenes locekḷa alkohola atkarības pieredze bērnībā ir būtisks faktors, kas paredz internalizētu un eksternalizētu uzvedību un stresa pārvarēšanas stratēgijas. Pētijjumā piedalījās 234 respondenti (189 sievietes un 45 vīrieši) vecumā no 18 līdz 59 gadiem. Respondenti aizpildīja Traumatisko pagātnes notikumu aptauju, Alkoholatkarīga gimenes locekḷa bērnu noteikšanas testa saīsināto versiju, Ahenbaha pieaugušo pašnovērtējuma anketu vecumam no 18-59 gadiem un Stresa pārvarēšanas stratēgiju aptauju. Pētijuma rezultāti rāda, ka ğimenes locekḷa alkohola atkarības pieredze bērnībā paredz tikai eksternalizētu uzvedību ar zemu īpatsvaru. Turpretim izvairǐ̌anās stratēgijas izmantošana pieaugušā vecumā nozīmīgi izskaidro internalizētu un eksternalizētu uzvedību. Savukārt bērnībā piedzīvota emocionāla vardarbība pieaugušajiem paredz uz problēmu un emocijām vērstu stresa stratēgiju pielietošanu, pamešana novārtā paredz izvairī̌̌anās stratēg̣iju izmantošanu, bet gimenes locekḷa alkohola atkarības pieredze bērnībā neparedz nevienu no stresa pārvarēšanas stratēgijām.
\end{abstract}

Atslēgas vārdi: alkohola atkarība, traumatiska pagātnes pieredze, stresa pārvarēšanas stratēgijas, eksternalizèta uzvedìba, internalizēta uzvedìba.

\section{Internalizing and Externalizing Behavior, Coping Strategies, Traumatic Childhood Events and Experience of Alcohol Addicted Family Member in Childhood}

\author{
Iveta Damroze and Laura Pirsko
}

University of Latvia

\begin{abstract}
The aim of the study was to examine whether the experience of alcohol abuse by a family member in childhood and traumatic childhood events are important factors in predicting internalizing and externalizing behaviours and coping strategies. There were a total of 234 participants, 189 women and 45 men, aged from 18 to 59 years old.

Participants completed the following questionnaires: Traumatic Antecedents Questionnaire, Modified Children of Alcoholics Screening Test, Achenbach Adult Self-Report for Ages 18-59, and The Coping Orientation of Problem Experience /COPE/ Inventory. Research results
\end{abstract}

Corresponding author: Laura Pirsko, University of Latvia, Jurmalas gatve 76, Riga LV-1083, Latvia. Email: laura.pirsko@lu.lv 
showed that the experience of alcohol abuse by a family member in childhood predicted adult externalizing behavior ratings. Traumatic childhood experience and avoidant coping strategies predicted internalizing and externalizing behavior ratings. Coping strategies were predicted by emotional abuse and childhood neglect, but not by experience of alcohol abuse by a family member in childhood.

Keywords: alcohol abuse, traumatic childhood events, coping strategies, internalizing behaviour, externalizing behaviour.

Problemātiskai alkohola lietošanai ir būtiska ietekme ne tikai uz pašu alkoholatkarīgo indivīdu, bet arī uz gímenes sistēmu kopumā, t. sk., ilgstoši ietekmējot bērna psihoemocionālo attīstību. Lai sniegtu atbalstu, Amerikā 20. gs. 70. gados sāka veidoties pirmās pašpalīdzību grupas pieaugušajiem alkoholatkarīgu vecāku bērniem, vienlaikus pastiprināti veicinot interesi par šo grupu zinātniskajos pētījumos. Kopumā pētījumi par pieaugušajiem alkoholatkarīgo vecāku bērniem ir l̦oti neviennozīmīgi, bieži pat pretrunīgi. Daļa pētījumu rāda, ka lielai daḷai pieaugušo alkoholatkarīgo vecāku bērnu ir lielāks risks dzīves laikā attīstīt destruktīvus uzvedības model̦us (Drapkin, Eddie, Buffington, \& McCrady, 2015). Taču ir arī tādi pieaugušie alkoholatkarīgu vecāku bērni, kuri kopumā neuzrāda kādas noteiktas psiholoğiskās problēmas (Menees \& Segrin, 2000).

Sākotnēji pieaugušie alkoholatkarīgo vecāku bērni literatūrā tika aprakstīti vairāk kā homogēna grupa ar līdzīgu bērnības pieredzi, tomēr sākot ar 20. gs. 90. gadiem pētījumos arvien vairāk iezīmējās šìs grupas heterogēnais raksturs. Līdz ar to jaunākajos pētījumos tiek skaidrotas ne tikai atškirības starp pieaugušajiem alkoholatkarīga gimenes locekḷu bērniem un pieaugušajiem bez šādas pieredzes, bet arī variācijas pieaugušo alkoholatkarīga ǵimenes locekḷa bērnu izlasē, īpašu uzsvaru liekot tieši uz dažādu traumatisku bērnības pieredzi.

\section{Pieaugušo alkoholatkarīgu gímenes locekḷu bērnu psihosociālās un uzvedības} ipatnības. Par pieaugušajiem alkoholatkarīgo ǵimenes locekḷu bērniem literatūrā tiek dēvēti tie pieaugušie, kuri uzauguši ǵimenē un tikuši pakḷauti vismaz viena vecāka, vecvecāka vai kāda cita gimenes locekḷa audzināšanai, kam bijusi alkohola atkarība (Beesley \& Stoltenberg, 2002).

Daudzi pētījumi rāda, ka aprūpējošās personas alkohola atkarība var negatīvi ietekmēt bērnu, tam sasniedzot arī pieaugušā vecumu - pieaugušie alkoholatkarīgo gimenes locekḷ bērni vairāk uzrāda stresu, viṇiem ir tendence neadaptīvā veidā reagèet uz dažādiem dzīves notikumiem, kā arī, salīdzinot ar pieaugušajiem bez šādas bērnības pieredzes, viṇiem ir izteiktāki psiholoğiskie simptomi (Hall \& Webster, 2002).

Pieaugušie alkoholatkarīgo ǵimenes locekḷu bērni uzrāda vairāk depresīvus simptomus gan neklīniskā, gan arī klīniskā izlasē (Harter, 2000; Hall \& Webster, 2002). Sievietēm, kuras nāk no gimenēm ar alkohola atkarību, ir lielāks depresijas vai distīmijas risks nekā vīriešiem ar tādu pašu ǵimenes vēsturi (Kelley et al., 2014). Daḷa pētījumu apstiprina, ka pieaugušajiem alkoholatkarīgo ǵimenes locekḷu bērniem ir izteiktāks arī trauksmes līmenis, it īpaši specifiskas fobijas, panikas traucējumi, un generalizētas 
trauksmes traucējumi (Mathew, Wilson, Blazer, \& George, 1993). Tomēr ir arī pētījumi, kuri neapstiprina būtiskas atšķirīibas trauksmes rādītājos starp pieaugšajiem ar un bez alkoholatkarības pieredzes gimenē bērnībā (Hill et al., 1992).

Ir maz veiktu pētījumu par saistību ar antisociālu uzvedību pieaugušajiem alkoholatkarīgo gimenes locekḷu bērniem - neklīniskajā izlasē tika atklāts, ka viniiem ir izteiktākas antisociālās iezīmes (Mathew et al., 1993), savukārt studentu izlasē netika apstiprināta šāda saistība (Harter, 2000).

Savukārt citi pētījumi rāda, ka pieaugušajiem, kuri auguši ğimenēs ar alkoholatkarīgu vecāku, ir lielāks risks lietot dažādas atkarību izraisošas vielas, viniiem biežāk novērojama problemātiska alkohola lietošana, uzvedības problēmas un personības traucējumi (Drapkin, et al., 2015).

Jāṇem vērā, ka nevis pats fakts, ka indivīds uzaudzis ğimenē, kur kādam no giimenes locekliem bijusi alkohola atkarïba, bet gan daudzveidīgu faktoru mijiedarbïba nosaka, vai bērns ar alkoholatkarīga ǵimenes locekḷa pieredzi kā pieaugušais piedzìvos negatīvas sekas - piemēram, bērna vecums, kad sākās ǵimenes locekḷa alkohola atkarība, kā arī smaguma pakāpe, kādā tika patērēts alkohols, sociālā atbalsta pieejamība.

Alkoholatkarība ir saistīta ar daudziem stresoriem gimenē, piemēram, gimenes locekḷa psihopataloǵiju, neatbilstošu bērnu aprūpi, konfliktiem ǵimenē, zemu socioekonomisko stāvokli, un tas kopā ar citiem bērnam traumatiskiem notikumiem vardarbības pieredzi, pamešanu novārtā, vecāku šķišanos, kā arī tuvinieka nāvi, fiziskiem vai garīgiem traucējumi - ir primārais faktors, kas ietekmē izmaiņas bērna emocionālajā, kognitīvajā vai uzvedības sfērā (Harter \& Taylor, 2000; Jacob \& Windle, 2000). Tieši šo stresoru kopums rada nelabvēlīgu ietekmi uz indivìda dzīvesspēku turpmākajā attīstībā. Lai arī ne visi pieaugušie alkoholatkarīgo gimenes locekḷu bērni piedzīvo psiholog̣iskas grūtîbas, turklāt tiem indivīdiem, kuri ir piedzīvojuši mazāk negatīvu pieredzi kā bērni, ir tendence uzrādīt mazāk izteiktas psiholoğiskās problēmas kā pieaugušajiem (Sheridan \& Green, 1993), tomēr pētỉjumi rāda, ka viņi ir vieglāk ievainojami pret dažadiem stresoriem, kā arī uzrāda vairāk psihologíisko simptomu nekā indivīdi bez šādas pieredzes (Hall \& Webster, 2002). Pieaugušie alkoholatkarīgo gimenes locekḷu bērni, kuri papildus bija piedzīvojuši arī citu traumatisku pieredzi, uzrādīja izteiktākus dusmu, aizkaitināmības iezīmju rādītājus, salīdzinot ar pieaugušiem alkoholatkarīgo gimenes locekḷu bērniem, kuri nebija piedzīvojuši traumatisku pieredzi, un kontrolgrupu, kura nebija piedzīvojusi ne traumatisku notikumus, ne vecāku alkoholatkarību bērnībā (Hall \& Webster, 2007).

Traumatiska bērnības pieredze. Psihiska trauma var būt jebkurš notikums, kas iedarbojas uz indivīdu un pēkšņi nomāc indivīda spēju nodrošināt minimālu drošības izjūtu un integratīvu veseluma izjūtu, kā rezultātā rodas ieilgušas izmaiņas psihiskā organizācijā un indivīds piedzìvo trauksmi, bezspēcību vai apdraudējumu (Cooper, 1986; kā minēts Negele, Kaufhold, Kallenbach, \& Leuzinger-Bohleber, 2015).

Daudzi pētijumi norāda, ka traumatiskai bērnības pieredzei ir būtiska ietekme psihisko traucējumu veicināšanā un izplatībā pieaugušo vecumā. Pētījumi rāda, ka bērniem līdz 5 gadu vecumam, kas piedzìvojuši pamešanu novārtā, seksuālu 
un/vai fizisku vardarbību, ir lielāks risks piedzīvot trauksmes un depresijas simptomus pieaugušā vecumā, nekā tiem indivīdiem, kuri šos vardarbības veidus ir piedzīvojuši vēlākā vecumā (White et al., 2015). Šì nelabvēlīgā pieredze tiek saistīta pieaugušajiem ar garstāvokḷa traucējumiem (Widom, DuMont, \& Czaja, 2007), uzmanības deficīta/ hiperaktivitātes sindromu (Rucklidge, Brown, Crawford, \& Kaplan, 2006), azartspēl̦u, vielu atkarību (Kausch, Rugle, \& Rowland, 2006), pēctraumatisko stresa sindromu (Yehuda, Halligan, \& Grossman, 2001) un personības traucējumiem (Rademaker, Vermetten, Geuze, Muilwijk, \& Kleber, 2008).

Stresa pārvarēšanas stratēgiijas. Psiholoǵiskais stress ir nevis pats notikums, bet rezultāts, indivīdam zaudējot līdzsvaru starp vides prasībām un saviem resursiem, bet stresors ir tie apstāḳ̣i, kas tiek novērtēti kā apdraudoši un pārsniedz indivīdam pieejamos resursus, lai pārvarētu stresu (Lazarus \& Folkman, 1984; kā minēts Ahmad \& Nazly, 2015).

Par stresa pārvarēšanas stratēgijām tiek uzskatīta atbildes reakcija uz stresu un nelabvēlīgu notikumu (Carver \& Connor-Smith, 2010). Šìs stratēgijas ir pastāvīgi mainīgi kognitīvi un uzvedības centieni tikt galā ar noteiktām ārējām vai iekšèjām prasībām, ko indivīds uztver kā apgrūtinājumu vai resursu iztukšošanu (Lazarus \& Folkman, 1984; kā minēts Rafnsson, Jonsson, \& Windle, 2006). Par nozīmīgākajām stratēgijām, kas fokusējas uz dažādu stresa pārvarēšanas reakcijām pozitīvo un negatīvo ietekmi, tiek uzskatītas: 1) uz problēmu vērsta - mainīt stresu izraisošo situāciju; 2) uz emocijām vērstā stratēgija - mainīt emocionālo atbildes reakciju uz stresoru; 3) izvairīšanās - pūles ir saistītas ar novēršanos no darbības kā atbildes reakcija uz grūtībām (Rafnsson et al., 2006).

To, cik atbilstoša situācijai ir katra stratēgóija, nosaka konkrētā situācija, kas nozīmē, ka viena specifiska stratēǵija var būt gan adaptīva, gan arī neadaptīva atškirīīās situācijās. Daži pētījumi rāda, ka stresa pārvarēšanas stratēgijas ir noturīgas laikā (Powers, Gallagher-Thompson, \& Kraemer, 2003) un uzskatāmas par predispozīciju (Moos \& Holahan, 2003) reaǵēt uz stresoru noteiktā veidā.

Pētījumi rāda, ka uz problēmām vērstas stratēǵijas ir saistītas ar efektīvāku un veselīgāku psiholoǵisko funkcionēšanu, kamēr uz emocijām vērstās stratēgijas un izvairī̌̌anās stratēg̣ijas tiek saistītas ar lielākām emcionālām un uzvedības grūtībām (Compas, Malcarne, \& Fondacaro, 1988), kā arī ar atkarību izraisošu vielu lietošanu (Cooper, Russell, \& George, 1988).

Uzvedības īpatnības pieaugušajiem. Problemātiskas uzvedības simptomi var izpausties kā eksternalizēta un internalizēta uzvedība.

Kā viena no eksternalizētās uzvedības izpausmēm jāmin antisociāla uzvedība. Tā ir indivīda rīcība, kad tiek pārkāpti sabiedrībā pieņemti noteikumi un normas, citas personas vai īpašuma tiesības (piemēram, zādzība, vandālisms, uzbrukums). Var runāt par divām antisociālās uzvedības dimensijām - viena ir atklāti agresīva, opozicionāra un otra - slēpta, neagresīva, noteikumus pārkāpjoša (Burt, Mikolajewski, \& Larson, 
2009). Divi nozīmīgākie riska faktori ir psihosociālie aspekti (vecāku audzināšanas stils, emocionāla trauma) vai bioloğiskie faktori (ǵenētika, toksisku ḳimisko vielu iedarbība).

Pētijjumi rāda, ka agresīvu uzvedību lielā mērā izskaidro tieši genēêtiskā pārmantojamība, bet vides faktoram ir maza nozīme, it ìpaši sākot ar pusaudžu gadiem. Savukārt noteikumus pārkāpjošu uzvedību paredz ne tikai genētiskais faktors, bet sevišșa nozīme ir tieši apkārtējās vides mijiedarbībai (Burt, 2009).

Atsevišķas internalizētās uzvedības izpausmes, piemēram, nomāktība un noslěšanās, ir aplūkojamas kā depresijas simptomātika. Skaidrojot tās attīstîbu, depresija ir daudzveidīgu - genētisku, biologisku, hormonālu - faktoru mijiedarbība, ko pastiprina apkārtējā vide. Daudzos pētījumos ir uzrādītas saistības starp traumatisku bērnības pieredzi un depresiju (MacMillan, et al., 2001). Tomēr, ja pieņem, ka traumatiska bērnības pieredze padara indivīdu ievainojamu pret depresiju, sastopieties ar stresoriem, tad varētu pieņemt, ka bērnības pieredzei ir būtiska nozīme depresijas attīstībā. Tomēr jaunākie pētījumi rāda, ka apmēram tikai 30\% no vēlīnā pieaugušo vecumā atklātiem psihiskiem traucējumiem ir saistīti ar traumatisku bērnības pieredzi (Green, McLaughlin, Berglund, Gruber, Sampson, Zaslavsk, \& Kessler, 2010).

Saistības starp pieaugušo alkoholatkarīgu gimenes locekḷ bērniem un stresa pārvarēšanas stratēǵijām. Uzaugot gimenē, kur kādam gímenes loceklim bijusi alkohola atkarība, indivīds laika gaitā ir attīstīiis noteiktas pielāgošanās prasmes, lai pārvarētu hronisko distresu. Vienlaikus, šìs stresa pārvarēšanas stratēgijas var būt arī kā mediators šo cilvēku dzīvespēkam (Drapkin, et al., 2015). Tomēr kopumā pētījumos iegūtie rezultāti ir pretrunīgi. Vienā no pētījumiem tika novērtētas specifiskas stresa pārvarēšanas stratēǵijas cilvēkiem ar alkoholatkarīgiem partneriem - 1) Iesaistǐšanās, kad līdzcilvēki iesaistās ǵimenes locekḷa atkarībā - strīdoties, lai apturētu alkohola patērēšanu, tāpat arī iznīcinot alkoholiskos dzērienus un mēǵinot pārliecināt atkarīgo, ka viņa uzvedībai ir negatīva ietekme uz līdzcilvēkiem; 2) Iecietība - alkoholatkarīgā cilvēka nelabvēlīgās izturēšanās tolerēšana, kad ǵimenes locekḷi to attaisno vai jūtas bezcerīgi; 3) Attālināšanās, kad gimenes locekḷi fokusējas uz savu dzīvi, neliekoties zinis par alkoholatkarīgā indivīda dzīvi - necenšoties to mainìt vai piesegt. Rezultātā autori secināja, ka Iecietības stratēọija bija ievērojami saistīta ar izteiktākām fiziskām un psiholog̣iskām problēmām tiem indivīdiem, kuri bija tuvās attiecībās ar alkoholatkarīgu partneri. Taču šis pètijums attiecās uz indivīdiem, kuru partneriem bija alkohola atkarība, līdz ar to tas nepilnīgi atklāj pieaugušo alkoholatkarīgu gimenes locekḷu bērnu stresa pārvarēšanas stratēgijas un psiholog̣isko funkcionēšanu kopumā (Orford, Natera, Velleman et al., 2001).

Pieaugušie alkoholatkarīgu gimenes locekḷu bērni piedzīvotās stresa situācijas ǵimenē uztvēra kā nemaināmas vai nepieciešamas pieņemt notikušo (respektīvi, nespèjīgi tās ietekmēt), tāpat viṇi vairāk uzrādīja emocionāli iesaistošas un izvairīšanās stresa pārvarēšanas stratēgijas, ilgpilnas domas un palīdzības meklējumus (Clair \& Genest, 1987), salīdzinot ar pieaugušajiem bez šādas bērnības pieredzes. Turpretim sievietes ar un bez alkoholatkarīgiem gímenes locekḷiem bērnībā neuzrādīja statistiski nozīmīgas atškiriỉbas stresa pārvarēšanas stratēǵijās (Kelley \& Myers, 1996), taču 
sievietes ar alkoholatkarīgiem ğimenes locekḷiem uzrādīja augstākus depresīvo simptomu rādītājus nekā kontrolgrupa.

Savukārt, izmantojot Stresa pārvarēšanas stratēgiju aptauju (COPE; Carver et al, 1989), pieaugušie ar alkoholatkarīgiem ǵimenes locekḷiem bērnībā uzrādīja vairāk neiesaistīšanos rīcībā, noliegšanu, fokusēšanos uz emocijām un atbrīvošanos no tām, kā arī ievērojami izteiktāku alkohola lietošanu, lai pārvarētu grūtības, un depresijas simptomus (Klostermann, Chen, Kelley, Schroeder, Braitman, \& Mignone, 2011). Citā pētījumā šì grupa mazāk uzrādīja iesaistǐšanos, bet vairāk vispārējas ar alkoholismu saistītas stresa pārvarēšanas stratēǵijas un attālināšanos nekā kontrolgrupa (Drapkin et al., 2015). Savukārt sievietes vairāk uzrādīja iesaistīšanos, iecietību un vispārēju pārvarēšanu nekā vīrieši. Turklāt negatīvie dzīves notikumi pieaugušajiem ar alkoholatkarīgiem ğimenes locekḷiem tika saistīti vairāk ar pasīvu stresa pārvarēšanu (Drapkin et al., 2015). Līdzīgi rezultāti bija vērojami arī pirms tam veiktā pētījumā, kad šì grupa izmantoja mazāk aktīvu vispārēju stresa parvarēšanu, bet atsḳirībā no 2015. gada pētījumā, šeit gan alkoholatkarīgu gimenes locekḷu pieaugušie bērni, gan arī kontrolgrupa uzradīja līdzīgus rezultātus vispērājā izvairīšanās stratēgèijā (Hussong \& Chassin, 2004).

Apkopojot pētījumus, redzams, ka pieaugušie alkoholatkarīgu ǵimenes locekḷu bērni nav uzskatāmi par homogēnu grupu ar unikālām iezīmēm. Tomēr kopumā jāsecina, ka viṇi uzrāda augstākus psiholoǵisko grūtību rādītājus, nekā pieaugušie bez šādas pieredzes. Līdz ar to tika izvirzīti sekojoši pētījuma jautājumi:

1) Kādas sakarības pastāv starp uzvedības īpatnībām, stresa pārvarēšanas stratēgijām, traumatisku bērnības pieredzi un gimenes locekḷa alkohola atkarības pieredzi bērnībā?

2) Kāda traumatiska pieredze un stresa pārvarēšanas stratēğijas paredz internalizēto un eksternalizēto uzvedību, ja tiek kontrolēti demogrāfiskie rādītāji un ǵimenes locekḷa alkohola atkarības pieredze?

3) Kāda traumatiska pagātnes pieredze paredz uz problēmu vērstu, uz emocijām vērstu un izvairīšanās stratēgégiu?

\section{Metode}

\section{Pētỉjuma dalībnieki}

Pètījumā piedalījās 234 respondenti (189 sievietes un 45 vīrieši) vecumā no 18 līdz 59 gadiem $(\mathrm{M}=35,3$ gadi, $\mathrm{SD}=11,2)$.

\section{Instrumentārijs}

Lai noteiktu pieaugušā alkoholatkarīga ǵimenes locekḷa bērna pieredzi, tika izmantota Alkoholatkarīga ǵimenes locekḷa bērnu noteikšanas testa saīsinātā versija (Modified Children of Alcoholics Screening Test; CAST-6; Hodgins, Maticka-Tyndale, el-Guebaly, \& West, 1993; pētījuma ietvaros tika veikta šīs aptaujas sākotnējā adaptācija). Aptauja sastāv no 6 jautājumiem, kur respondenti sniedz "jā"/"nē" atbildes par savu pieredzi līdz 18 gadu vecumam, un uzrāda augstu iekšējo saskan,otības rādītāju $(\alpha=0,90)$. Oriǵinālā jautājumi ir saistīti ar vecāku alkohola lietošanas uzvedību, taču 
šajā pētỉjumā tā tika attiecināta uz gimenes locekliem kopumā, ar kuriem respondents ir dzīvojis ikdienā kopā. Šie 6 jautājumi ar faktoranalīzi ir atlasīti no Alkoholatkarīga gimenes locekḷa bērnu noteikšanas testa (Children of Alcoholics Screening Test; CAST, Jones, 1983; Latvijā adaptējusi Sijāte-Novicka, 2013), kur ir 30 apgalvojumi, un ìsajai versijai ir l̦oti laba korelācija ar pilno versiju $(\mathrm{r}=0,92$ - 0,94; Hodgins \& Shrimp, 1995; kā minēts Chalder, Elgar \& Bennett, 2006). Par katru atbildi “jā” respondenti sañēma 1 punktu. Respondenti, kuri kopā sañēma 3 līdz 6 punktus, tika iekḷauti grupā ar alkoholatkarīgu gimenes locekḷa pieredzi. Savukārt tie respondenti, kuri saṇēma 0 līdz 2 punktus, tika iekḷauti grupā bez alkoholatkarīga ğimenes locekḷa pieredzes.

Traumatiskas pagātnes pieredzes noteikšanai izmantota Traumatisko pagātnes notikumu aptauja (Traumatic Antecedents Questionnaire; TAQ; Herman, van der Kolk, 1987; Latvijā adaptējusi Maškanceva, 2012). Aptauju veido 42 apgalvojumi, kas respondentam jānovērtē ar "jā" vai "nē" atbildi. Oriǵinālā aptauja mēra dažādu traumatisko pagātnes pieredzi, kas veido 10 apakšskalas - kompetence, drošība, pamešana novartā, seperācija, gimenes noslēpumi, fiziska trauma, seksuāla trauma, vardarbïbas liecinieks, citas traumatiskas pieredzes (piemēram, dabas katastrofa, nelaimes gadijumi) un alkohola/ narkotiku atkarība. Ši pētijuma ietvaros tika izveidotas 6 apakšskalas, ticamïbas pārbaudē uzrādot gan labus un augstus, gan arī pazeminātus iekšējās saskaņotības rādītājus - 1) Emocionālā vardarbība $(\alpha=0,76), 2)$ Pamešana novārtā $(\alpha=0,56)$, 3) Fiziskās vardarbības liecinieks $(\alpha=0,69)$, 4) Fiziskā vardarbība $(\alpha=0,53), 5)$ Seksuālā vardarbība $(\alpha=0,64)$ un 6$)$ Neprecizēta traumatiska pieredze $(\alpha=0,60)$. Kopumā Traumatisko pagātnes notikumu aptaujas iekšejē saskaņotība ir laba $(\alpha=0,81)$, taču Neprecizētas traumatiskas pieredzes apakšskala uzrādīja zemu iekšējo saskaņotību, līdz ar to vairāki apgalvojumi, kas norādīja konkrētu traumatisku pieredzi (dabas katastrofa, nelaimes gadijumi u.c.), netika iekl̦auti.

Uzvedỉbas īpatnību noteikšanai tika izmantota Ahenbaha pieaugušo pašnovērtējuma anketa vecumam no 18-59 gadiem (Achenbach Adult Self-Report for Ages 18-59; Achenbach \& Rescorla, 2003; latviski adaptējusi Amoliņa, 2010). Anketā kopumā ir iekḷauti 131 apgalvojums, kas apvienoti 8 skalās: Trauksme/Nomāktība, Noslēgšanās sevī, Netipiska uztvere, Uzmanības problēmas, Agresīva uzvedība, Noteikumu pārkāpumi, Somatiskās raizes un Uzbāzīga uzvedība. Šajā pētījumā vairākas apakšskalas tika apvienotas, lai izveidotu Internalizētās uzvedības (Trauksme/Nomāktība, Noslēgšanās sevī, Somatiskās raizes) un Eksternalizētās uzvedības (Agresīva uzvedība, Noteikumu pārkāpumi un Uzbāzīga uzvedības) apakšskalas, kas ticamības pārbaudē uzrādīja augstus iekšèjās sakaņotības rādītājus - Internalizētā uzvedība $(\alpha=0,94)$, Eksternalizētā uzvedība $(\alpha=0,88)$. Respondenti dotos apgalvojumus novērtēja 3 punktu Likerta skalā no 0 (Neatbilst) līdz 2 (Pilnībā atbilst vai ḷoti bieži atbilst). Tā kā šajā pētỉjumā nebija nozīmīgi skalu klīniskie rādītāji, tad iegūtās jēlās balles netika pārvērstas standartizētās T vērtībās.

Vēl tika izmantota Stresa pārvarēšanas stratēgiju aptauja (The Coping Orientation of Problem Experience /COPE/ Inventory, Carver, Scheier, \& Weintraub, 1989; Latvijā aptauju adaptējusi Petrova, 2009, Knipše, 2011). Aptauju veido 60 apgalvojumi, kas mēra indivīda noteiktas stresa stratēgijas stresa situācijās, un apvienoti 15 apakšskalās: pozitīva pārvērtēšana un attīstība, mentāla neiesaistišanās, fokusēšanās uz emocijām 
un atbrīvošanās no tām, sociālā atbalsta meklēšana instrumentālos nolūkos, aktīva pārvarēšana, noliegums, pievēršanās reliğijai, humors, neiesaistīšanās rīcībā, savaldība, sociālā atbalsta meklēšana emocionālos nolūkos, alkohola/narkotiku lietošana, pieṇemšana, konkurējošo aktivitātes veidu apspiešana, plānošana. Šajā pētījumā šīs 15 apakšskalas tika apvienotas 3 skalās, kas ticamības pārbaudē uzrādīja augstus iekšējās sakaṇotības rādītājus - Uz problēmu vērstas stratēgijas $(\alpha=0,86)$, Uz emocijām vērstas stratēgijas $(\alpha=0,81)$ un Izvairī̌̌anās stratēgijas $(\alpha=0,82)$. Piedāvātie apgalvojumi respondentiem bija jānovērtē 4 punktu Likerta skalā gradācijā no 1 (Es gandrīz nekad tā nedaru) līdz 4 (Es gandrīz vienmēr tā daru).

Papildus tika uzdoti demogrāfiski jautājumi (dzimums, vecums, izglītība).

\section{Procedūra}

Pētījuma dati tika ievākti gan frontāli nejaušā veidā dažādās darba vietās un krīzes centrā, gan arī elektroniski sociālajos tīklos. Pirmā aptauja bija Ahenbaha pieaugušo pašnovērtējuma anketa, pēc tam sekoja Stresa pārvarēšanas stratēǵiju aptauja, trešā aptauja bija Traumatisko pagātnes notikumu aptauja, pēc tam sekoja Alkoholatkarīgu gimenes locekḷu bērnu noteikšanas tests. Noslēgumā respondenti norādīja demogrāfiskos datus.

\section{Rezultāti}

Lai atbildētu uz pirmo pētījuma jautājumu, kādas sakarības pastāv starp uzvedības īpatnībām, stresa pārvarēšanas stratēg̣ijām, traumatisku bērnības pieredzi un ǵimenes locekḷa alkohola atkarības pieredzi bērnībā, tika aprēksināti Pīrsona, Spīrmena rangu un punktu biseriālais korelācijas koeficienti (skat. 1. tabulu).

No rezultātiem var secināt, ka G̦imenes locekḷa alkohola atkarība statistiski nozīmīgi korelē ar Emocionālu vardarbību $(\mathrm{r}=0,14, \mathrm{p}<0,05)$, Fiziskās vardarbības liecinieku ( $\mathrm{r}=0,32, \mathrm{p}<0,01)$, Pamešanu novārtā $(\mathrm{r}=0,40, \mathrm{p}<0,01)$ un Eksternalizētu uzvedību $(\mathrm{r}=0,17, \mathrm{p}<0,05)$.

Statistiski nozīmīgas, pozitīvas sakarības pastāv starp Emocionālu vardarbību un Uz problèmu vērstām stratēgijām $(\mathrm{r}=0,14, \mathrm{p}<0,05)$, Uz emocijām vērstām stratēgijām ( $\mathrm{r}=0,18, \mathrm{p}<0,01)$ un Internalizètu uzvedību $(\mathrm{r}=0,22, \mathrm{p}<0,01)$. Pamešana novārtā statistiski nozīmīgi un pozitīvi korelē ar $U z$ emocijām vērstām stratēǵijām ( $\mathrm{r}=0,15$ $\mathrm{p}<0,05)$, Izvairīšanās stratēǵijām $(\mathrm{r}=0,15, \mathrm{p}<0,05)$, Internalizētu $(\mathrm{r}=0,22, \mathrm{p}<0,01)$ un Eksternalizētu $(\mathrm{r}=0,19, \mathrm{p}<0,01)$ uzvedību. Fiziskās vardarbības liecinieka rādītāji statistiski nozīmīgi, pozitīvi korelē ar Uz emocijām vērstu stratēgiju $(\mathrm{r}=0,15 \mathrm{p}<0,05)$ rādītājiem. Statistiski nozīmīgas, pozitīvas sakarības pastāv starp Fizisku vardarbību un Internalizētu $(\mathrm{r}=0,20, \mathrm{p}<0,01)$ un Eksternalizētu $(\mathrm{r}=0,16, \mathrm{p}<0,05)$ uzvedību. Seksuālā vardarbība statistiski nozīmīgi, pozitīvi korelē ar Eksternalizētu uzvedību ( $\mathrm{r}=0,14$, $\mathrm{p}<0,05)$. Neprecizētas traumatiskas pieredzes rādītāji statistiski nozīmīgi, pozitīvi korelē ar Internalizètās $(\mathrm{r}=0,25, \mathrm{p}<0,01)$ un Eksternalizètās $(\mathrm{r}=0,17, \mathrm{p}<0,01)$ uzvedības rādītājiem.

Statistiski nozīmīgas, negatīvas sakarības pastāv starp Uz problèmu vērstām stratēgijām un Internalizētu $(\mathrm{r}=-0,23, \mathrm{p}<0,01)$ un Eksternalizētu $(\mathrm{r}=-0,19, \mathrm{p}<0,01)$ 


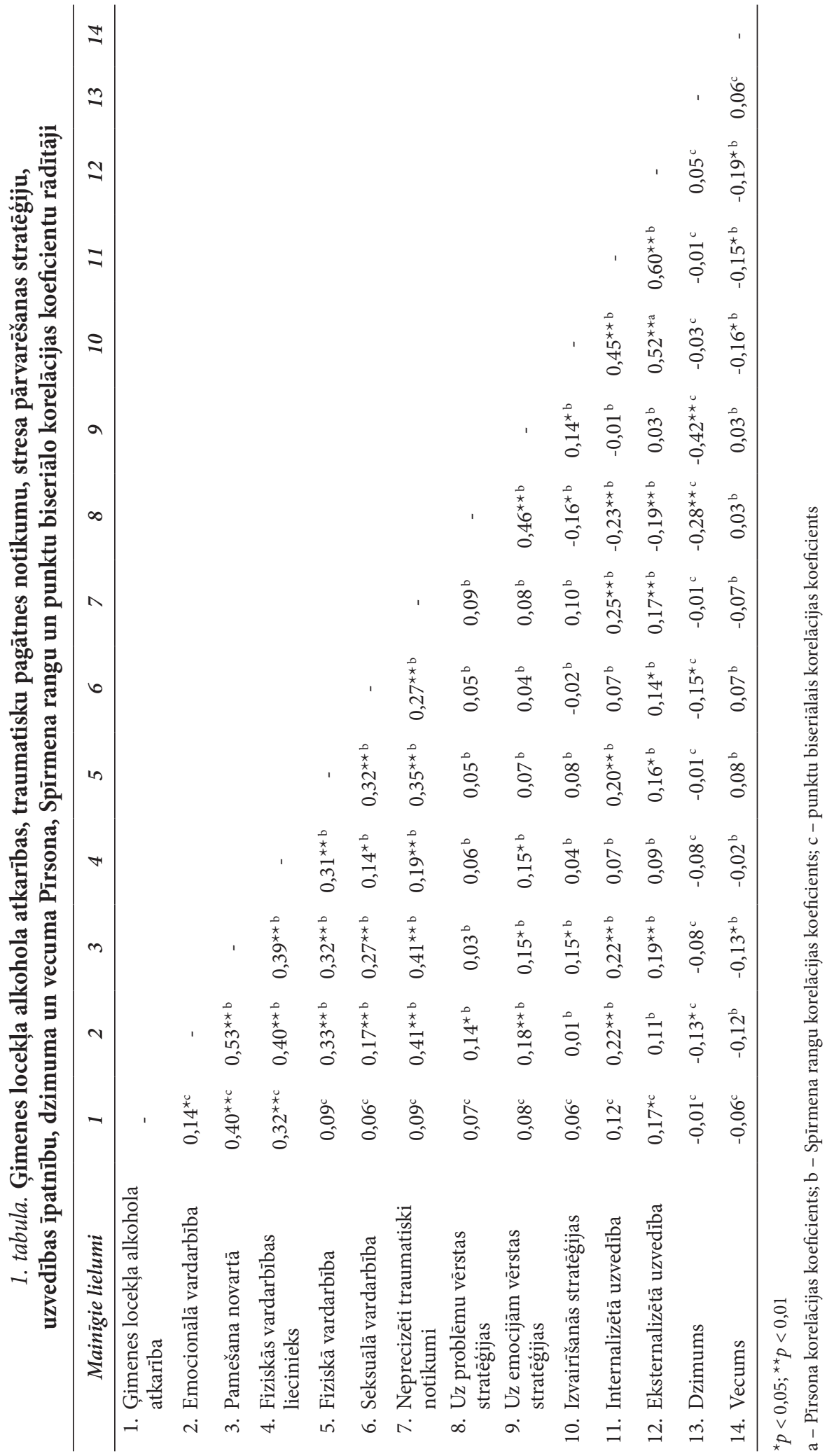


uzvedību, kas nozīmē, ka, pieaugot $U z$ problēmu vērsto stratēgiju rādītājiem, samazinās Internalizèto un Eksternalizèto uzvedību rādītāji. Izvairīšanās stratēóiju rādītāji statistiski nozīmīgi un pozitīvi korelē ar Internalizētās ( $\mathrm{r}=0,45, \mathrm{p}<0,01)$ un Eksternalizètās ( $\mathrm{r}=0,52, \mathrm{p}<0,01)$ uzvedības rādītājiem, kas nozīmē, ka, pieaugot Izvairīšanās stratēgiju rādītājiem, pieaug arī Internalizèto un Eksternalizēto uzvedību rādītāji.

Tā kā pētījuma izlase nav homogēna, tad arī dzimums un vecums tika iekḷauts korelācijā, lai noteiktu, vai starp šiem mainīgajiem pastāv statistiski nozīmīgas sakarības. Rezultāti rāda, ka Dzimums statistiski nozīmīgi, negatīvi korelē ar Emocionālas vardarbības $(\mathrm{r}=-0,13, \mathrm{p}<0,05)$, Seksuālās vardarbības $(\mathrm{r}=-0,15, \mathrm{p}<0,05)$, Uz problēmu vērstu stratēgiju $(\mathrm{r}=-0,28, \mathrm{p}<0,01)$ un $U z$ emocijām vērstu stratēǵiju $(\mathrm{r}=-0,42, \mathrm{p}<0,01)$ rādītājiem, kas nozīmē, ka sievietes uzrāda augstākus Emocionālās vardarbības, Seksuālās vardarbības, Uz problēmu un Uz emocijām vērstu stratēgijiu rādītājus. Savukārt Vecumam ir statistiski nozīmīga, negatīva korelācija ar Pamešanas novārtā ( $\mathrm{r}=-0,13$, $\mathrm{p}<0,05)$, Izvairǐšanās stratēǵiju $(\mathrm{r}=-0,16, \mathrm{p}<0,05)$, Internalizètās $(\mathrm{r}=-0,15, \mathrm{p}<0,05)$ un Eksternalizètās ( $\mathrm{r}=-0,19, \mathrm{p}<0,05)$ uzvedības rādītājiem, kas nozīmē, ka, pieaugot vecumam, samazinās Pamešanas novārtāa, Izvairī̌̌anās stratēgiju, Internalizētās un Eksternalziētās uzvedības rādītāji.

Atbildot uz otro pētījuma jautājumu, kāda traumatiska pieredze un stresa pārvarēšanas stratēgóijas paredz internalizēto un eksternalizēto uzvedība, ja tiek kontrolèti demogrāfiskie rādìtāji un ğimenes locekḷa alkohola atkarības pieredze, tika pielietota hierarhiskā regresiju analīze.

Veidojot Ineternalizētās uzvedības paredzes modeli, tajā tika iekḷauti tie mainīgie lielumi, kas statistiski nozīmīgi korelēja ar Internalizētu uzvedību. Pirmajā modelī kā atkarīgais mainīgais tika ievadīta Internalizēta uzvedība, bet kā neatkarīgais mainīgais Vecums. Otrajā modelī kā neatkarīgais mainīgais tika pievienota Ģimenes locekḷa alkohola atkarība. Pirmajos divos model̦os tika izmantota enter metode. Savukārt, izmantojot soḷu (stepwise) metodi, trešajā modelī kā neatkarīgais mainīgais klāt tik pievienota Izvairī̌sanās stratēógijas, bet 4. modelī - Neprecizèta traumatiska pieredze, 5. modelī - Uz problèmu vērstas stratēgijas un, visbeidzot, 6. modelī - Emocionāla vardarbība (skat. 2. tabulu). No regresiju analīzes tika izslēgta Pamešana novārtā un Fiziskā vardarbība, kas norāda, ka šie mainīgie lielumi nav statistiski nozīmīgi Internalizētās uzvedības izskaidrošanai.

Rezultāti rāda, ka visi seši model̦i ir statistiski nozīmīgi. Pirmajā modelī neatkarīgais mainīgais Vecums pats par sevi statistiski nozīmīgi izskaidro 2\% Internalizètās uzvedības rādītāju variāciju $\left(\mathrm{F}(1,232)=4,13, \mathrm{p}<0,05, \mathrm{R}^{2}=0,02\right)$. Taču otrajā modelī, pievienojot mainīgo lielumu Ģimenes locekḷa alkohola atkarība, redzama Vecuma ietekmes mazināšanās, kas ir statistiski nenozīmīgs Internalizētās uzvedības rādītāju izmaiņu noteicējs $(\mathrm{F}(2,231)=3,44, \mathrm{p}=0,06)$, tāpat arī Ģimenes locekḷ a alkohola atkarība statistiski nozīmīgi neparedz Internalizētās uzvedības rādītājus $(\mathrm{F}(2,231)=3,44, \mathrm{p}=0,10)$. Trešajā modelī papildus tika pievienota Izvairī̌̌anās stratēógijas. Šāds modelis paredz 22\% Internalizētās uzvedības rādītāju variāciju, bet Izvairīšanās stratēógijas statistiski nozīmīgi papildus izskaidro $19 \%$ Internalizètās uzvedības rādītāju variāciju $\left(\mathrm{F}(3,230)=21,58, \mathrm{p}<0,001, \mathrm{R}^{2}=0,22, \Delta \mathrm{R}^{2}=0,19\right)$. Gan trešajā, gan arī turpmākajos model̦os Vecums un Ģimenes locekḷa alkohola atkarība 


\section{2. tabula. Hierarhiskās regresiju analīzes rezultāti atkarīgajam mainīgajam}

Internalizētā uzvedība

\begin{tabular}{|c|c|c|c|c|c|c|}
\hline Neatkarīgais mainīgais & $B$ & $S E B$ & $\beta$ & $R^{2}$ & $\Delta R^{2}$ & $F$ \\
\hline 1. modelis & & & & 0,02 & 0,02 & $4,13^{*}$ \\
\hline Vecums & $-0,16$ & 0,08 & $-0,13^{*}$ & & & \\
\hline 2. modelis & & & & 0,03 & 0,01 & $3,44^{\star}$ \\
\hline Vecums & $-0,15$ & 0,08 & $-0,13$ & & & \\
\hline G̣imenes locekḷa alkohola atkarība & 2,89 & 1,75 & 0,11 & & & \\
\hline 3. modelis & & & & 0,22 & 0,19 & $21,58^{\star * *}$ \\
\hline Vecums & $-0,07$ & 0,07 & $-0,06$ & & & \\
\hline Ģimenes locekḷa alkohola atkarība & 2,27 & 1,58 & 0,08 & & & \\
\hline Izvairīšanās stratēgijas & 0,77 & 0,10 & $0,44^{* * *}$ & & & \\
\hline 4. modelis & & & & 0,26 & 0,04 & $19,95^{\star \star *}$ \\
\hline Vecums & $-0,06$ & 0,07 & $-0,05$ & & & \\
\hline G̦imenes locekḷa alkohola atkarība & 1,84 & 1,55 & 0,07 & & & \\
\hline Izvairīšanās stratēǵijas & 0,74 & 0,10 & $0,43^{* * *}$ & & & \\
\hline Neprecizēti traumatiski notikumi & 4,02 & 1,16 & $0,20^{* *}$ & & & \\
\hline 5. modelis & & & & 0,29 & 0,03 & $18,78^{\star * *}$ \\
\hline Vecums & $-0,05$ & 0,07 & $-0,05$ & & & \\
\hline G̦imenes locekḷa alkohola atkarība & 2,21 & 1,52 & 0,08 & & & \\
\hline Izvairīšanās stratēgijas & 0,70 & 0,10 & $0,41^{* * *}$ & & & \\
\hline Neprecizēti traumatiski notikumi & 4,40 & 1,14 & $0,22^{* *}$ & & & \\
\hline Uz problēmu vērstas stratēgijas & $-0,27$ & 0,08 & $-0,19^{* *}$ & & & \\
\hline 6. modelis & & & & 0,31 & 0,02 & $17,16^{\star * *}$ \\
\hline Vecums & $-0,04$ & 0,07 & $-0,04$ & & & \\
\hline Ģimenes locekḷa alkohola atkarïba & 1,80 & 1,51 & 0,07 & & & \\
\hline Izvairīšanās stratēgijas & 0,72 & 0,10 & $0,42^{* * *}$ & & & \\
\hline Neprecizēti traumatiski notikumi & 3,11 & 1,24 & $0,15^{\star}$ & & & \\
\hline Uz problēmu vērstas stratēǵijas & $-0,30$ & 0,08 & $-0,20^{* * *}$ & & & \\
\hline Emocionālā vardarbība & 1,29 & 0,50 & $0,16^{*}$ & & & \\
\hline
\end{tabular}

${ }^{*} p<0,05,{ }^{* *} p<0,01,{ }^{* * *} p<0,001$

statistiski nozīmīgi neizskaidro Internalizētās uzvedības rādītāju. Ceturtais modelis, papildus pievienojot Neprecizētu traumatisku pieredzi, izskaidro $26 \%$ no Internalizètās uzvedības variācijas, bet Neprecizèta traumatiska pieredze šajā modelī papildus izskaidro $4 \%$ Internalizētās uzvedības rādītāju variāciju $\left(\mathrm{F}(4,229)=19,95, \mathrm{p}<0,001, \mathrm{R}^{2}=0,26\right.$, $\left.\Delta \mathrm{R}^{2}=0,04\right)$. Nākošajā, piektajā modelī klāt tika iekl̦autas Uz problēmu vērstas stratēgijas, un šis modelis paredz $29 \%$ Internalizētās uzvedības rādītāju variāciju, bet Uz problēmu vērstas stratēgíijas izskaidro 3\% no Internalizētās uzvedības variācijas $(\mathrm{F}(5,228)=18,78$, $\left.\mathrm{p}<0,001, \mathrm{R}^{2}=0,29, \Delta \mathrm{R}^{2}=0,03\right)$. Visbeidzot, sestais modelis, kurā papildus pievienota Emocionālā vardarbība, izskaidro 31\% Internalizētās uzvedības rāditāju variāciju $\left(\mathrm{F}(6,227)=17,16, \mathrm{p}<0,001, \mathrm{R}^{2}=0,31, \Delta \mathrm{R}^{2}=0,02\right)$, bet Emocionālā vardarbība izskaidro $2 \%$ no Internalizètās uzvedības variācijas. Šajā modelī Izvairīšanās stratēǵijas ir ar visnozīmīgāko ìpatsvaru $(\beta=0,42, \mathrm{p}<0,001)$, bet $U z$ problēmu vērstas stratégijas $(\beta=-0,20, \mathrm{p}<0,001)$, Emocionāla vardarbība $(\beta=0,16, \mathrm{p}<0,05)$ un Neprecizéta traumatiska pieredze $(\beta=0,15, \mathrm{p}<0,05)$ sniedz papildu neatkarīgu efektu. 
Veidojot Eksternalizètās uzvedības paredzes modeli, tajā tika iekḷauti tie mainīgie lielumi, kas statistiski nozīmīgi korelēja ar eksternalizētu uzvedību, un dzimums, jo pētījuma izlase nav homogēna. Pirmajā modelī kā atkarīgais mainīgais tika ievadìta Eksternalizēta uzvedība, bet kā neatkarīgais mainīgais - Dzimums. Otrajā modelī kā neatkarīgais mainīgais tika pievienota ǵimenes locekḷa alkohola atkarība. Pirmajos divos modeḷos tika izmantota enter metode. Savukārt trešajā modelī kā neatkarīgais mainīgais klāt tika pievienota Izvairīšanās stratégija, ceturtajā modelī - Uz problēmu vērstas stratēgijas, bet 5. modelī - Neprecizèta traumatiska pieredze. Pēdējos 3 modelıs izmantota soḷu (stepwise) metode (skat. 3. tabulu). No regresiju analīzes tika izslēgta Pamešana novārtā, Fiziskā vardarbība un Seksuālā vardarbība, kas norāda, ka šie mainīgie lielumi nav statistiski nozīmīgi Eksternalizētās uzvedības izskaidrošanai.

\section{3. tabula Hierarhiskās regresiju analīzes rezultāti atkarīgajam mainīgajam Eksternalizētā uzvedība}

\begin{tabular}{|c|c|c|c|c|c|c|}
\hline Neatkarīgais mainīgais & $B$ & $S E B$ & $\beta$ & $R^{2}$ & $\Delta R^{2}$ & $F$ \\
\hline 1. modelis & & & & 0,00 & 0,00 & 0,62 \\
\hline Dzimums & 1,14 & 1,45 & 0,05 & & & \\
\hline 2. modelis & & & & 0,03 & 0,03 & $3,68^{*}$ \\
\hline Dzimums & 1,16 & 1,43 & 0,05 & & & \\
\hline Ģimenes locekl̦a alkohola atkarība & 2,94 & 1,13 & $0,17^{\star}$ & & & \\
\hline 3. modelis & & & & 0,29 & 0,26 & $31,85^{* * *}$ \\
\hline Dzimums & 1,52 & 1,23 & 0,07 & & & \\
\hline Ģimenes locekl̦a alkohola atkarība & 2,39 & 0,97 & $0,14^{*}$ & & & \\
\hline Izvairišanās stratēgeijas & 0,58 & 0,06 & $0,51^{\star * *}$ & & & \\
\hline 4. modelis & & & & 0,31 & 0,02 & $25,90^{* * *}$ \\
\hline Dzimums & 0,63 & 1,27 & 0,03 & & & \\
\hline G̦imenes locekl̦a alkohola atkarība & 2,59 & 0,97 & $0,15^{\star *}$ & & & \\
\hline Izvairī̌sanās stratēgijas & 0,56 & 0,06 & $0,50^{\star * *}$ & & & \\
\hline Uz problēmu vērstas stratēgijas & $-0,14$ & 0,06 & $-0,14^{\star *}$ & & & \\
\hline 5. modelis & & & & 0,33 & 0,02 & $22,39^{* * *}$ \\
\hline Dzimums & 0,57 & 1,26 & 0,03 & & & \\
\hline Ģimenes locekḷa alkohola atkarība & 2,41 & 0,96 & $0,14^{*}$ & & & \\
\hline Izvairišanās stratēgeijas & 0,54 & 0,06 & $0,48^{* * *}$ & & & \\
\hline Uz problēmu vērstas stratēgegijas & $-0,15$ & 0,06 & $-0,16^{\star *}$ & & & \\
\hline Neprecizēta traumatiska pieredze & 1,77 & 0,72 & $0,14^{*}$ & & & \\
\hline
\end{tabular}

${ }^{*} p<0,05,{ }^{* *} p<0,01,{ }^{* * *} p<0,001$

Rezultāti rāda, ka četri no pieciem model̦iem ir statistiski nozīmīgi. Pirmajā modelī neatkarīgais mainīgais Dzimums pats par sevi statistiski nozīmīgi neizskaidro Eksternalizētās uzvedības rādītāju variāciju $(\mathrm{F}(1,232)=0,62, \mathrm{p}=0,43)$. Arī turpmākajos četros model̦os Dzimums nav statistiski nozīmīgs Eksternalizētās uzvedības rādītāju izmaiṇu noteicējs. Otrajā modelī, pievienojot mainīgo lielumu Ģimenes locekḷa alkohola atkarība, redzams, ka šis neatkarīgais mainīgais lielums paredz 3\% Eksternalizètās uzvedības rādītāju variāciju $\left(\mathrm{F}(2,231)=3,68, \mathrm{p}<0,05, \mathrm{R}^{2}=0,03, \Delta \mathrm{R}^{2}=0,03\right)$. Trešajā modelī papildus tika pievienotas Izvairī̌sanās stratēǵijas, un šāds modelis izskaidro 29\% Eksternalizētās uzvedības rādītāju variāciju $\left(\mathrm{F}(3,230)=31,85, \mathrm{p}<0,001, \mathrm{R}^{2}=0,29\right)$, bet Izvairīšanās stratēǵijas papildus izskaidro 26\% Eksternalizētās uzvedības variāciju 
$\left(\Delta \mathrm{R}^{2}=0,26\right)$. Ceturtajā modelī tikai Uz problēmu vērstas stratēgijas paredz $2 \%$ no Eksternalizētās uzvedības rādītājiem $\left(\mathrm{F}\left(4,229=25,90, \mathrm{p}<0,001, \mathrm{R}^{2}=0,31, \Delta \mathrm{R}^{2}=0,02\right)\right.$, savukārt 4 mainīgie no visiem mainīgajiem kopā spēj izskaidrot $31 \%$ no Eksternalizētās uzvedības rādītāju variāciju $\left(\mathrm{F}(4,229)=25,90, \mathrm{p}<0,001, \mathrm{R}^{2}=0,31\right)$. Visbeidzot, piektajā modelī papildus tika pievienota Neprecizèta traumatiska pieredze, un šāds modelis izskaidrot 33\% Eksternalizētās uzvedības rādìtāju variāciju $(\mathrm{F}(5,228)=22,39$, $\left.\mathrm{p}<0,001, \mathrm{R}^{2}=0,33\right)$, Neprecizèta traumatiska pieredze papildus, statistiski nozīmīgi izskaidro $2 \%$ Eksternalizētās uzvedības variāciju. Šajā modelī Izvairī̌sanās stratēgijas ir ar visnozīmīgāko īpatsvaru $(\beta=0,48, \mathrm{p}<0,001)$, bet $U z$ problèmu vērstas stratēǵijas $(\beta=-0,16, \mathrm{p}<0,001)$, Neprecizèta traumatiska pieredze $(\beta=0,14, \mathrm{p}<0,05)$ un Gimenes loceklı alkohola atkarība $(\beta=0,14, \mathrm{p}<0,05)$ sniedz papildu neatkarīgu efektu.

Atbildot uz pētījuma papildjautājumu, kāda traumatiska pagātnes pieredze paredz uz problēmu vērstu, uz emocijām vērstu un izvairīšanās stratēéiju, tika izmantotu soḷu regresiju analīze. No regresiju analīzes tika izslēgtas tādas traumatiskas pieredzes kā Fiziskā vardarbība, Seksuālā vardarbība, Neprecizēta traumatska pieredze un Ģimenes locekḷa alkohola atkarība, kas norāda, ka šie rādītāji nav statististiski nozīmīgi stresa pārvarēšanas stratēóiju izskaidrošanai.

Rezultāti rāda (skat. 4. tabulu), ka tikai Emocionāla vardarbība statistiski nozīmīgi paredz 3\% no Uz problēmu vērstu stratēgiju rādìtājiem $(\mathrm{F}(1,232)=5,91, \mathrm{p}>0,05$, $\left.\mathrm{R}^{2}=0,03\right)$.

4. tabula Soḷu regresiju analīzes rezultāti atkarīgajam mainīgajam Uz problèmu vērstas stratēğijas

\begin{tabular}{|c|c|c|c|c|c|c|}
\hline Modelis & Neatkarīgais mainīgais & $B$ & $S E B$ & $\beta$ & $R^{2}$ & $F$ \\
\hline 1 & & & & & 0,03 & $5,91^{*}$ \\
\hline & Emocionāla vardarbība & 0,86 & 0,35 & $0,16^{*}$ & & \\
\hline
\end{tabular}

${ }^{*} p<0,05$

Rezultāti rāda (skat. 5. tabulu), ka Emocionāla vardarbība statistiski nozīmīgi paredz $3 \%$ no Uz emocijām vērstu stratēéiju rādītājiem $\left(\mathrm{F}(1,232)=7,53, \mathrm{p}>0,01, \mathrm{R}^{2}=0,03\right)$.

5. tabula Soḷu regresiju analīzes rezultāti atkarīgajam mainīgajam Uz emocijām vērstas stratēgijas

\begin{tabular}{|c|c|c|c|c|c|c|}
\hline Modelis & Neatkarīgais mainīgais & $B$ & SE B & $\beta$ & $R^{2}$ & $F$ \\
\hline 1 & & & & & 0,03 & $7,53^{* *}$ \\
\hline & Emocionāla vardarbība & 0,89 & 0,33 & $0,18^{\star *}$ & & \\
\hline
\end{tabular}

${ }^{* *} p<0,01$

Pēc rezultātiem (skat. 6. tabulu) redzams, ka Pamešana novārtā statistiski nozīmīgi paredz $2 \%$ no Izvairǐšanās stratẹǵiju rādītājiem $\left(\mathrm{F}(1,232)=4,18, \mathrm{p}>0,05, \mathrm{R}^{2}=0,02\right)$.

6. tabula Soḷu regresiju analīzes rezultāti atkarīgajam mainīgajam Izvairīšanās stratēǵijas

\begin{tabular}{lcccccc}
\hline \multicolumn{1}{c}{ Modelis } & Neatkarīgais mainīgais & $B$ & $S E B$ & $\beta$ & $R^{2}$ & $F$ \\
\hline \multirow{2}{*}{ Pamešana novartā } & & & & 0,02 & $4,18^{*}$ \\
& & 0,71 & 0,35 & $0,13^{*}$ & & \\
\hline
\end{tabular}

${ }^{*} p<0,05$ 


\section{Diskusija}

Veiktā pētijuma mērķis bija noskaidrot, vai gimenes locekḷa alkohola atkarība un cita traumatiska pagātnes pieredze bērnībā ir būtisks faktors, kas paredz internalizētas un eksternalizētas uzvedības un stresa pārvarēšanas stratēǵiju rāditājus pieaugušajiem.

Atbildot uz šĩ pètijuma jautājumu, kādas sakarības pastāv starp uzvedības īpatnībām, stresa pārvarēšanas stratēǵijām, traumatisku bērnības pieredzi un gimenes locekḷa alkohola atkarību, iegūtie rezultāti rāda, ka tie cilvēki, kuru ğimenes locekḷiem ir bijusi alkohola atkarība, uzrāda izteiktāku emocionālās vardarbības, pamešanas novārtā un fiziskās vardarbỉbas liecinieka pieredzi, kas saskan ar iepriekšējiem pētijumiem. Turklāt emocionālā vardarbība ir pamatā jebkurai citai traumatiskai pieredzei, kā arī tās efekts uz indivīdu var būt daudz negatīvāks nekā seksuālai vai fiziskai vardarbībai (Iwaniec, 1997).

Tāpat šì pētijjuma rezultāti rāda, ka indivīdi ar alkoholatkarīgu gimenes locekḷa pieredzi bērnībā uzrāda izteiktākas eksternalizētās uzvedības īpatnības nekā indivīdi bez alkoholatkarīga gimenes locekḷa. Iepriekš aplūkotos pētījumos minētas saistības starp vecāku alkoholismu un antisociālu uzvedību, impulsivitāti, problemātisku alkohola lietošanu (Harter, 2000; Mathew et al., 1993).

Veiktā pētījuma rezultāti norāda, ka izteiktākas internalizētās uzvedības īpatnības pieaugušajiem ir saistītas ar izteiktāku emocionālās un fiziskās vardarbības, pamešanas novārtā un neprecizētu traumatisku notikumu pieredzi bērnībā, bet izteiktākas eksternalizētās uzvedības īpatnības pieaugušajiem - ar izteiktāku fiziskās un seksuālās vardarbỉbas, pamešanas novārtā un neprecizētu traumatisku notikumu pieredzi bērnībā.

Daudzi iepriekš veiktie pētījumi uzrāda sakarības starp visu veidu traumatiskajām pieredzēm un dažādiem traucējumiem. Normanes (Norman) ar kolēgiem veiktajā metaanalīzē, kurā tika iekḷauti 124 pētijumi, rezultāti rāda, ka emocionāla vardarbība un pamešana novārtā bērnībā ir cieši saistīta ar depresijas un trauksmes traucējumiem, pašnāvības mēgeinājumiem, narkotiku lietošanu un riskantu seksuālo uzvedību pieaugušā vecumā, bet fiziska vardarbība - ne tikai ar iepriekš minēto, bet arī ar ēšanas traucējumiem un uzvedības traucējumiem bērnībā (Norman, Byambaa, De, Butchart, Scott, \& Vos, 2012). Savukārt seksuālā vardarbība ir saistìta ar pēctraumatiskā stresa traucējumiem, internalizētu un eksternalizētu uzvedību (Trask, Walsh, \& DiLillo, 2011). Turpretim unikālās sakarības pastāv starp emocionālu vardarbību un zemu pašvērtējumu, starp fizisku vardarbību un agresiju, un starp seksuālu vardarbību un problemātisku seksuālo uzvedību (Higgins \& McCabe, 2003). Tomēr kopumā pētījumos parādās tikai nelielas atšķirības starp dažādām traumatiskām pieredzēm un psihologiskiem traucējumiem (Higgins \& McCabe, 2003). Tā kā nav skaidru teorētisko nostādṇu, vai starp traumatiskās pieredzes veidiem patiešām pastāv būtiskas atškíirības un tie aplūkojami kā neatkarīgi viens no otra, vai tomēr traumatiska pieredze ir konstrukts pats par sevi, tad nav arī tādas visaptverošas teorijas, kas spētu skaidrot specifiskas sekas katram traumatiskās pieredzes veidam atseviškłi (Higgins, 2004).

Aplūkojot saistības starp traumatisku bērnïbas pieredzi un stresa pārvarēšanas stratēgiijām, veiktā pētījuma rezultāti atklāj, jo izteiktāka uz problēmu vērstu stratēǵiju izmantošana, jo izteiktāka arī emocionālās vardarbības pieredze bērnībā, bet, jo 
izteiktāka uz emocijām vērstu stratēgiju izmantošana, jo izteiktāka arī emocionālās vardarbības, pamešanas novārtā un fiziskās vardarbības liecinieka pieredze. Visbeidzot, izteiktāka izvairišanās stratēǵiju izmantošana ir saistīti ar izteiktāku pamešanas novārtā pieredzi bērnībā.

Traumatisku notikumu pieredze var veicināt noteiktu stratēgiju izmantošanu, kas var kalpot kā adaptīvs veids, lai pārvarētu traumatisko notikumu, taču ilgtermiņā šì stratēégija var nelabvēlīgi ietekmēt indivīda psiholog̣isko funkcionēšanu. Tā, piemēram, izvairišanās un uz emocijām vērstas stratēgijas tiek uzskatītas par adaptīvu reakciju uz neizbēgamiem un nelabvēlīgiem notikumiem, tādejādi īslaicīgi mazinot distresu, negatīvas emocijas, bezspēcības izjūtu (Hager \& Runtz, 2012). Pārsteidzoši, ka arī uz problēmu vērstas stratēgijas ir saistìtas ar emocionālu vardarbỉbu. Maz ir tādu pētỉjumu, kas atklāj saistības starp adaptīvu funkcionēšanu un uz problēmu vērstu stratēgiju izmantošanu, piemēram, indivīdiem ar seksuālas vardarbības pieredzi bērnībā (Gipple, Lee, \& Puig, 2006). Taču pētnieki norāda, ka adaptīvās stratēǵijas traumas pārvarēšanai ir mazāk izplatītas, ja tiek salīdzinātas ar tiem indivīdiem, kuriem nav bijusi traumatiska pieredze (Gagne \& Melacon, 2013).

Visbeidzot, šajā pētījumā iegūtie rezultāti rāda, ka izteiktāka izvairīšanās stratēǵiju izmantošana ir saistīta ar izteiktāku internalizētu un eksternalizētu uzvedību pieaugušajiem. Savukārt izteiktāka uz problēmu vērstu stratēǵiju pielietošana ir saistīti ar zemākiem internalizētās un eksternalizētās uzvedības rādītājiem.

Daudzos pētỉjumos izvairīšanās netiek uzskatīta par adaptīvu stresa pārvarēšanas stratēgiiju ilgtermin̄ā (Sesar, Simic, \& Barisic, 2010). Turklāt izvairǐšanās tiek saistìta ar internalizētām un eksternalizētām grūtībām - depresiju (Morris et al., 2014), trauksmi (Blalock \& Joiner, 2000), pēctraumatiskā stresa traucējumiem (Street, Gibson, \& Holohan, 2005), riskantu uzvedību (Spaccarelli \& Fuchs, 1997). Arī pētījumi ar pusaudžiem uzrāda, ka traumatiska pieredze negatīvi ietekmē indivīdu spēju pārvarēt stresu izraisošus notikumus turpmāk, attīstot mazāk efektīvus paņēmienus grūtību pārvarēšanā, bet vienlaikus palielinot internalizētos simptomus (Guerra et al., 2016), un tas var turpināties arī pieaugušà vecumā. Savukārt aktīvas stresa pārvarēšanas stratēgijas var samazināt trauksmi un vairot optimismu (Yaqoob \& Khan, 2014).

Atbildot uz otro pētījuma jautājumu, kāda traumatiska pieredze bērnībā un stresa pārvarēšanas stratēǵijas paredz internalizēto un eksternalizēto uzvedību pieaugušajiem, ja tiek kontrolēti demogrāfiskie rādìtāji un giimenes locekḷa alkohola atkarības pieredze, veiktā pētijuma rezultāti atklāj, ka gan internalizētās, gan arī eksternalizētās uzvedības izteiktākas īpatnības paredz izteiktāka neprecizētu traumatisku notikumu pieredze un izvairišanās stratēǵiju izmantošana, kā arī vājāka uz problēmu vērstas stratēǵiju izmantošana. Turklāt izvairī̌sanās stratēgijas ir nozīmīgākais uzvedības îpatnību paredzētājs. Jāpiezīmē, ka demogrāfiskie rādītāji neietekmē pētỉjuma rezultātus.

Kā jau norādīts iepriekš, izvairīšanās stratēǵija īslaicīgi ir uzskatāma par adaptīvu traumatisku notikumu pārvarēšanas pieeju. Taču pastāvīga šīs stratēgijas izmantošana var aprūtināt indivīda spēju tikt galā ar jauniem stresoriem, kas, savukārt, var apgrūtināt indivīda adaptīvu funkcionēšanu turpmāk. Pētijumi rāda, ka izvairīšanās stratēgeijas ir saistìtas ar negatīiām gaidām, ka noteikta uzvedība vai domas varētu mazināt negatīvu noskaņojumu (Catanzaro, Horaney and Creasey, 1995). Tas norāda, ka indivīdi, kuri 
izmanto izvairǐšanās stratēgijas, ir pārliecināti, ka viṇi nevar regulēt savas uzvedības grūtỉbas adaptīvā veidā. Turklāt izvairīšanās var aktivizēt uzmācīgas domas par stresoru, kas, savukārt, veicina trauksmi un nomāktību (Carver \& Connor-Smith, 2010).

Turpretim uz problēmu vērstas stratēgijas var tikt aplūkots kā aizsargfaktors. Folkmane un Lazaruss skaidro, ka indivīda pašizjūtu uzlabo tas, ja viņš var atrisināt stresu izraisošas problēmas, turklāt, plānojot problēmas risināšanu, tas var uzlabot savstarpējās attiecības, pozitīvi mainìt kogitīvo novērtējumu un veicināt pozitīvas sekas emocionālajā sfērā (Folkman \& Lazarus, 1990; kā minēts Sesar et al., 2010).

Vēl šì pētījuma rezultāti atklāj, ka emocionāla vardarbība paredz tikai internalizētu uzvedību. Kā jau iepriekš minēts, pētījumi uzrāda nozīmīgu saistîbu starp emocionālu vardarbību un depresiju, trauksmi. Atsevišķi pētnieki izvirza pien̦ēmu, ka tieši emocionālā vardarbība ir vairāk saistīta ar depresijas attīstîbu nekā pārējie vardarbības veidi (Liu, Alloy, Abramson, Iacoviello, \& Whitehouse, 2009). Pieaugušais, kurš ir emocionāli vardarbīgs, negatīvi un vistiešākajā veidā iedarbojas uz bērna kognitīvo izpratni par sevi (Rose \& Abramson, 1992), piemēram, kad vecāks bērnu kritizē. Turpretim bērns, kurš ir piedzīvojis fizisku vai seksuālu vardarbību, potenciāli var attīstīt labvēlīgāku kognitīvo izpratni par sevi, jo to tiešā veidā veido pats bērns, nevis pieaugušais. Kognitīvais stils jeb veids, kādā cilvēki interpretē dažādus notikumus, var padarìt vinus ievainojamus pret depresijas attīstîbu. Longitudinālā pētījumā tika secināts, ka emocionāla vardarbība, nevis fiziska vai seksuāla vardarbība, ir saistīta ar depresiju (Gibb et al., 2001).

Vēl veiktā pētijuma rezultāti uzrāda, ka uzaugšana gimenē ar alkoholatkarīgu gimenes locekli bērnībā paredz tikai eksternalizētās grūtības. Šos rezultātus teorētiski varētu skaidrot ar to, ka alkohola atkarība bieži ir saistīta ar savstarpēji vardarbīgām attiecībām starp pieaugušajiem, bet bērns ir tieši pakḷauts gimenes locekḷu dažādām agresivitātes izpausmēm. Pētījumi atklāj, ka tiem bērniem, kuru vecāki ir savstarpēji vardarbīgi, pieaug dispozīcija attīstìt agresivitāti, vardarbīgu izturēšanos un delikventu uzvedību (McFarlane, Groff, O’Brien, \& Watson, 2003). Sociālās iemācǐšanās teorija (Bandura, 1986; kā minēts Klostermann \& Kelley, 2009) uzsver, cik socializēšanās un psihologiski veselīgas attiecības ar vecākiem ir nozīmīgas, lai bērns attīstītu prosociālu uzvedību un pārliecības. Turpretim problemātiska alkohola lietošana un agresīva, vardarbīga uzvedība tiek iemācītas, galvenokārt, caur attiecībām, kas tiek nodotas no paaudzes uz paaudzi. Turklāt indivīds iemācās, ka agresija un vardarbība ir pieņemams veids, kā risināt konfliktus. Lìdz ar to bērns apgūst arī vājas stresa pārvarēšanas stratēǵijas (piemēram, alkohola lietošana, agresija). Tomēr jāṇem vērā, ka iegūtie pētījuma rezultāti norāda, ka gimenes locekḷ a alkohola atkarība izskaidro l̦oti maz no eksternalizētās uzvedības variācijas. Kā rāda iepriekš veiktie pētỉjumi, tad eksternalizētās uzvedības variāciju nozīmīgāk izskaidro tieši biolog̣iskie faktori (Niv, Tuvblad, Raine, \& Baker, 2013).

Atbildot uz šì darba papildjautājumu, kāda traumatiska pagātnes pieredze paredz uz problēmu vērstu, uz emocijām vērstu un izvairīšanās stratēgeiju, rezultāti uzrāda, ka gimenes locekḷa alkohola atkarība neparedz nevienu no stresa pārvarēšanas stratēgijām. Jānem vērā, ka šì pētỉjuma rezultātu nevar attiecināt uz populāciju kopumā, taču rezultāti l̦auj secināt, ka ǵimenes locekḷa alkohola atkarības pieredze pati par sevi nav 
noteicošais faktors, kas veicinātu specifiskas stresa pārvarēšanas stratēgijas indivīdiem ar pietiekoši adaptīvu funkcionēšanu.

Būtiski ir akcentēt metodolog̣iskos aspektus iepriekšèjos pētījumos, lai skaidrotu šādus rezultātus. Vairumā pētījumos izlase tiek sadalīta grupās ar un bez alkoholatkarīga ǵimenes locekḷa pieredzes bērnībā, un pēc tam šīs abas grupas tiek salīdzinātas. Taču pieredze, kad kādam no ǵimenes locekḷiem ir alkohola atkarība, var tikt aplūkota daudz plašākā traumatisku notikumu kontekstā kā dažādu veidu stresori un vardarbība. Tomēr pētījumos visbiežāk šie daudzveidīgie aspekti netiek kontrolēti un ṇemti vērā (Meness \& Segrin, 2000). Vismaz pusē no pētījumiem ar pieaugušajiem alkoholatkarīgu ǵimenes locekḷu bērniem respondenti ir studenti (Vail, Protinsky, \& Prouty, 2000). Tā, piemēram, kādā no pētījumiem bija nozīmīgas atšķirības starp pieaugušajiem alkoholatkarīgu vecāku bērniem studentu un nestudentu izlasēs (Shapiro, Weatherford, Kaufman, and Broenen, 1994; kā minēts Vail et al., 2000). Turklāt studentu izlase kopumā nereprezentē vispārēju populāciju, līdz ar to pētījumu rezultātus var attiecināt tikai uz konkrēto izlasi.

Par pētījuma stipro pusi var uzskatīt, pirmkārt, izlasi - tā ir apjomīga, arī vecuma diapozons ir plašs. Tas l̦auj secināt, ka šì nav studentu izlase, kas ir bijis būtisks ierobežojums daudzos iepriekš veiktajos pētījumos. Otrkārt, pētot pieaugušos alkoholatkarīgu ǵimenes locekḷu bērnus, ir ņemta vērā arī dažāda traumatiska pieredze, kas l̦auj daudz skaidrāk interpretēt iegūtos rezultātus.

Norādot pētījuma ierobežojumus, jāmin, ka izmantotā Traumatisko notikumu aptauja mēra, vai respondents ir saskāries ar kādu traumatisku notikumu, nevis tās izteiktību - biežumu, smagumu -, un tas var ietekmēt rezultātus. Turklāt pašnovērtējuma aptaujās sniegtās atbildes ir pakḷautas neobjektivitātei, ko ietekmē garastāvoklis aizpildīšanas brīdī, kā arī psihologiskie aizsargmehānismi (noliegšana, traumatiskās pieredzes izstumšana) it īpaši sevišḳi smagas traumatiskās pieredzes gadījumā. Tāpat arī šì pētījuma dalībnieku pašreizējās psiholoǵiskās grūtības var ietekmēt retrospektīvs bērnības novērtējums, piemēram, pārspīlējo bērnības pieredzi, lai izskaidrotu respondenta pašreizējās psiholoǵiskās grūtībās (Higgins \& McCabe, 2003). Par vēl vienu ierobežojumu jāmin tas, ka pētījumā nav arī ņemtas vērā personības iezīmes, kuras ir saistītas ar spēju tikt galā ar dažām stresu izraisošām situācijām (Hengartner et al., 2015).

Turpmākajos pētījumos būtu vērts iekḷaut tādus mainīgos, kas ḷautu labāk izprast tos faktorus, kas ietekmē traumatiskas pieredzes sekas, un ir saistīti ar predispozīciju attīstīt dažādus internalizētus un eksternalizētus uzvedības simptomus, piemēram, personības iezīmes, temperaments. Nemot vērā atzin̦as psihologiskajos pētījumos, būtu nozīmīgi pētījumos lielāku uzmanību pievērst tieši traumatiskās izteiktības pakāpei, biežumam un arī vecumposmam, kad indivīds ir piedzīvojis psihiski traumatisku notikumu, tādejādi tas ḷautu iegūt precīzākus rezultātus starp dažādiem pētāmajiem konstruktiem.

Rezumējot jāsecina, ka pieredze, ka indivīds ir uzaudzis ǵimenē ar alkoholatkarīgu gimenes locekli, izskaidro maz - tikai eksternalizētu uzvedību. Savukārt internalizēto un eksternalizēto uzvedību daudz nozīmīgāk izskaidro izvairīšanās stratēgeijas. Līdz ar to šī pētījuma rezultāti ḷauj izprast, ka, strādājot konsultēšanā ar klientu, kurš uzaudzis 
gimenē ar alkoholatkarīgu ǵimenes locekli, daudz būtiskāk ir pievērst uzmanību tam, kā klients tiek galā ar dažādām grūtībām, un kādu tieši traumatisku pieredzi piedzīvojis bērnībā, nevis uz faktu, ka kādam no ğimenes locekḷiem bijusi alkohola atkarība.

\section{Izmantotā literatūra}

Ahmad, M. M., \& Nazly, E. K. A. (2015). Hemodialysis: Stressors and coping strategies. Psychology, Health, and Medicine, 20, 477-487.

Beesley, D., \& Stoltenberg, C. D. (2002). Control, attachment style, and relationship satisfaction among adult children of alcoholics. Journal of Mental Health Counseling, 24, 281-298.

Blalock, J. A., \& Joiner, T. E. (2000). Interaction of cognitive avoidance coping and stress in predicting depression/anxiety. Cognitive Therapy and Research, 24, 47-65.

Burt, S. A. (2009). Are there meaningful etiological differences within antisocial behavior? Results of a meta-analysis. Clinical Psychology Review, 29, 163-178.

Burt, A., S., Mikolajewski, A. J., \& Larson, C. L. (2009). Do aggression and rule-breaking have different interpersonal correlates? A study of antisocial behavior subtypes, negative affect, and hostile perceptions of others. Aggressive Behavior, 35, 453-461.

Carver, S. C., Connor-Smith, J. (2010). Personality and coping: Annual Review of Psychology, 61, 679-704.

Carver, C. S., Scheier, M. F., \& Weintraub, J. K. (1989). Assessing coping strategies: A theoretically based approach. Journal of Personality and Social Psychology, 56, 267-283.

Catanzaro, S. J., Horaney, F., \& Creasey, G. (1995). Hassles, coping, and depressive symptoms in an elderly community sample: The role of mood regulation expectancies. Journal of Counseling Psychology, 42, 259-265.

Chalder, M., Elgar, F. J., \& Bennett, P.(2006). Drinking and motivations to drink among adolescent children of parents with alcohol problems. Alcohol and Alcoholism, 41, 107-113.

Clair, D., Genest, M. (1987). Variables associated with the adjustment of offspring of alcoholic fathers. Journal of Studies of Alcohol, 48, 345-55.

Compas, B. E., Malcarne, V. L., \& Fondacaro, K. M. (1988). Coping with stressful events in older children and young adolescents. Journal of Consulting and Clinical Psychology, 56, 405-411.

Cooper, A. (1986). Toward a limited definition of psychic trauma. In A. Rothstein (Ed.), The Reconstruction of Trauma (pp. 41-56). Madison: International Universities Press.

Cooper, M. L., Russell, M., \& George, W. H. (1988). Coping, expectancies, and alcohol abuse: a test of social learning formulations. Journal of Abnormal Psychology, 97, 218-30.

Drapkin, M. L., Eddie, D., Buffington, A. J., \& McCrady, B. S. (2015). Alcohol-specific coping styles of adult children of individuals with alcohol use disorders and associations with psychosocial functioning. Alcohol and Alcoholism, 50, 1-7.

Gibb, B. E., Alloy, L. B., Abramson, L. Y., Whitehouse, W. G., Donovan, P., Hogan, M. E., Cronholm, J. \& Tierney, S. (2001). History of childhood maltreatment, negative cognitive styles, and episodes of depression in adulthood. Cognitive Therapy and Research, 25, 425-446.

Green, J., McLaughlin, K., Berglund, P., Gruber, M., Sampson, N., Zaslavsky, A., \&Kessler, R. (2010). Childhood adversities and adult psychiatric disorders in the national comorbidity survey replication I: Associations with first onset of DSM-IV disorders. Archives of General Psychiatry, 67, 113-123. 
Guerra, C., Pereda, N., Guilera, G., \& Abad, J. (2016). Internalizing symptoms and polyvictimization in a clinical sample of adolescents: The roles of social support and nonproductive coping strategies. Child Abuse \& Neglect, 54, 57-65.

Hager, A. D., \& Runtz, M. G. (2012). Physical and psychological maltreatment in childhood and later health problems in women: an exploratory investigation of the roles of perceived stress and coping strategies. Child Abuse and Neglect, 36, 393-403.

Hall, C. W., \& Webster, R. E. (2002). Traumatic symptomatology characteristics of adult children of alcoholics. Journal of Drug Education, 32, 195-211.

Hall, C. W., \& Webster, R. E. (2007). Risk factors among adult children of alcoholics. International Journal of Behavioral Consultation and Therapy, 3, 494-511.

Harter, S. L. (2000). Psychosocial adjustment of adult children of alcoholics: A review of the recent empirical literature. Clinical Psychology Review, 20, 311-337.

Harter, S. L., \& Taylor, T. L. (2000). Parental alcoholism, child abuse, and adult adjustment. Journal of Substance Abuse, 11, 31-44.

Hengartner, M. P., Cohen, L. J., Rodgers, S., Muller, M., Rossler, W., \& Ajdacic-Gross, V. (2015). Association between childhood maltreatment and normal adult personality traits: exploration of an understudied field. Journal of Personality Disorders, 29, 1-14.

Higgins, D. J., \& McCabe, M. P. (2003). Maltreatment and family dysfunction in childhood and the subsequent adjustment of children and adults. Journal of Family Violence, 18, 107-120.

Hodgins, D. C., Maticka-Tyndale, E., El-Guebaly, N., \& West, M. (1993). The CAST-6: development of a short-form of the children of alcoholics screening Test. Addictive Behaviors, $18,337-345$.

Hussong, A. M., \& Chassin, L. (2004). Stress and coping among children of alcoholic parents through the young adult transition. Development of Psychopathology, 16, 985-1006.

Iwaniec, D. (1997). An overview of emotional maltreatment and failure-to-thrive. Child Abuse Review, 6, 370-388.

Jacob, T., \& Windle, M. (2000). Young adult children of alcoholic, depressed and nondistressed parents. Journal of Studies on Alcohol, 61, 836-844.

Kausch, O., Rugle, L. and Rowland, D. Y. (2006). Lifetime histories of trauma among pathological gamblers. American Journal on Addictions, 15, 35-43.

Kelley, M. L., Linden, A. N., Milletich, R. J., Lau-Barraco, C., Kurtz, E. D., D'Lima, G. M., Bodkins, J. A., \& Sheehan, B. E. (2014). Self and partner alcohol-related problems among ACOAs and non-ACOAs: associations with depressive symptoms and motivations for alcohol use. Addictive Behaviors, 39, 211-228.

Klostermann, K., Chen, R., Kelley. M. L., Schroeder, Braitman, A., \& Mignone, T. (2011). Coping behavior and depressive symptoms in adult children of alcoholics. Substance Use \& Misuse, 46, 1162-1168.

Klostermann, K., \& Kelley, M. L. (2009). Alcoholism and intimate partner violence: effects on children's psychosocial adjustment. International Journal of Environmental Research and Public Health, 6, 3156-3168.

Lazarus, R., \& Folkman, S. (1984). Stress, appraisal and coping. New York, NY: Springer.

Liu, R. T., Alloy, L. B., Abramson, L. Y., Iacoviello, B. M. \& Whitehouse, W. G. (2009). Emotional maltreatment and depression: prospective prediction of depressive episodes. Depress and Anxiety, 26, 174-181. 
MacMillan, H., Fleming, J., Streiner, D., Lin, E., Boyle, M., Jamieson, E., Duku, E., Walsh, C., Wong, M., \& Beardslee, W. (2001). Childhood abuse and lifetime psychopathology in a community sample. American Journal of Psychiatry, 158, 1878-1883.

Mathew, R. J., Wilson, W. H., Blazer, D. G., \& George, L. K. (1993). Psychiatric disorders in adult children of alcoholics: data from the epidemiologic catchment area project. American Journal of Psychiatry, 150, 793-800.

McFarlane, J. M., Groff, J. Y., O’Brien J. A., \& Watson, K. (2003). Behaviors of children who are exposed and not exposed to intimate partner violence: an analysis of 330 black, white, and Hispanic children. Pediatrics, 112, 202-207.

Menees, M. M., \& Segrin, C. (2000). The specificity of disrupted processes in families of adult children of alcoholics. Alcohol \& Alcoholism, 35, 361-367.

Moos, R. H., \& Holahan, C. J. (2003). Dispositional and contextual perspectives on coping: Toward an integrative framework. Journal of Clinical Psychology, 59,1387-1403.

Morris, M. C., Kouros, C. D., Fox, K. R., Rao, U. \& Garber, J. (2014). Interactive models of depression vulnerability: The role of childhood trauma, dysfunctional attitudes, and coping. British Journal of Clinical Psychology, 53, 245-263.

Negele, A., Kaufhold, J., Kallenbach, L., \& Leuzinger-Bohleber, M. (2015). Childhood trauma and its relation to chronic depression in adulthood. Depression Research and Treatment, 2015, 1-11.

Niv, S., Tuvblad, C., Raine, A., \& Baker, L. A. (2013). Aggression and rule-breaking: heritability and stability of antisocial behavior problems in childhood and adolescence. Journal of Criminal Justice.

Norman, R. E., Byambaa, M., De, R., Butchart, A., Scott, J., Vos, T. (2012). The long-term health consequences of child physical abuse, emotional abuse, and neglect: A systematic review and meta-analysis. PLoS Medicine, 9, e1001349.

Orford, J., Natera, G., Velleman, R., Copello, A., Bowie, N., Bradbury, C., et al. (2001). Ways of coping and the health of relatives facing drug and alcohol problems in Mexico and England. Addiction, 96, 761-774.

Powers, D. V., Gallagher-Thompson, D., \& Kraemer, H. C. (2003). Coping and depression in Alzheimer's caregivers: longitudinal evidence of stability. Journal of Gerontology, 57, 205-211.

Rademaker, A. R., Vermetten, E., Geuze, E., Muilwijk, A. \& Kleber, R. J. (2008). Self-reported early trauma as a predictor of adult personality: a study in a military sample. Journal of Clinical Psychology, 64, 863-875.

Rafnsson, F. D., Jonsson, F. H., \& Windle, M. (2006). Coping strategies, stressful life events, problem behaviors, and depressed affect. Anxiety, Stress, and Coping, 19, 241-257.

Rose, D. T., \& Abramson, L. Y. (1992). Developmental predictors of depressive cognitive style: Research and theory. In: Cicchetti D, Toth S, editors. Rochester Symposium of Developmental Psychopathology. Vol. 4. University of Rochester Press; Rochester, NY, 323-349.

Sesar, K., Simic, N., \& Barisic, M. (2010). Multi-type childhood abuse, strategies of coping, and psychological adaptation in young adults. Croatian Medical Journal, 51, 406-416.

Sheridan, M. J., \& Green, R. G. (1993). Family dynamics and individual characteristics of adult children of alcoholics: An empirical analysis. Journal of Social Service Research, 17, 73-97.

Spaccarelli, S., \& Fuchs, C. (1997). Variability in symptom expression among sexually abused girls: developing multivariate models. Journal of Clinical Child Psychology, 26, 24-35. 
Street, A. E., Gibson, L. E. \& Holohan, D. R. (2005). Impact of childhood traumatic events, trauma-related guilt, and avoidant coping strategies on PTSD symptoms in female survivors of domestic violence. Journal of Traumatic Stress, 18, 245-252.

Trask, E. V., Walsh, K., \& DiLillo, D. (2011). Treatment effects for common outcomes of child sexual abuse: A current meta-analysis. Aggression and Violant Behavior, 16, 6-19.

Vail, M. O., Protinsky, H., \& Prouty, A. (2000). Sampling issues in research on adult children of alcoholics: adolescence and beyond. Adolescence, 35, 113-119.

White, L. O., Klein, A. M., Kirschbaum, C., Kurz-Adam, M., Uhr, M., Müller-Myhsok, B., Hoffmann, K., Sierau, S., Michel, A., Stalder, T., Horlich, J., Keil, J., Andreas, A., Resch, L., Binser, M., Costa, A., Giourges, E., Neudecker, E., Wolf, C., \& Scheuer, S. (2015). Analyzing pathways from childhood maltreatment to internalizing symptoms and disorders in children and adolescents (AMIS): a study protocol. BMC Psychiatry, 15, 1-18.

Yaqoob, N., \& Khan, M. A. (2014). Patterns of depression, anxiety symptoms and coping styles among early and late adolescent students. Pakistan Armed Forces Medical Journal, 64, 573-576.

Yehuda, R., Halligan, S. L., \& Grossman, R. (2001). Childhood trauma and risk for PTSD: relationship to intergenerational effects of trauma, parental PTSD, and cortisol excretion. Development and Psychopathology, 13, 733-753. 


\title{
Datorspēlu prosociālas vai agresīvas lomas spēlēšanas ietekme uz jauniešu agresīvām izjūtām un prosociālo spriešanu
}

\author{
Mihails Limonovs un Sandra B. Sebre ${ }^{1}$
}

Latvijas Universitāte

\begin{abstract}
Abstrakts
Šì pētījuma mērḳis bija noskaidrot, vai jaunieši, kuri spēlēs vardarbīgo datorspēli, ieṇemot prosociālu lomu, uzrādīs zemākus agresīvās izjūtas rādītājus un augstākus prosociālas spriešanas rādītājus nekā jaunieši, kuri spēlēs datorspēli, ieņemot agresīvu lomu. Lai sasniegtu šo mērḳi, pētījumā tika iesaistīti 46 dalībnieki, kuri nejaušības kārtā tika sadalīti divās grupās: dalībnieki, kuri spēlēja vardarbīgu datorspēli, ieņemot agresīvo lomu kā ložmetējnieki ( $n=23$; un dalībnieki, kuri spēlēja vardarbīgu datorspēli, ieņemot prosociālo lomu kā mediḳi $(\mathrm{n}=23)$. Pètījumā piedalījās 26 sievietes un 20 vīrieši vecumā no 19 līdz 27 gadiem, vidējais respondentu vecums bija 22,24 gadi (SD = 2,11). Lai mērītu agresīvās izjūtas, dalībnieki aizpildīja Dusmu pašnovērtējuma anketas dusmu stāvokḷa skalu (The State Trait Anger Expression Inventory, Spielberger, 1999). Lai mērītu prosociālo spriešanu, dalībnieki aizpildīja Prosociālas un morālas spriešanas mērījumu (Objective Measure of Prosocial Moral Reasoning, Gustavo, Eisenberg, \& Knight, 1992). Pētījuma rezultāti uzrādīja to, ka dalībnieki, kuri spēlēja datorspēli prosociālā mediķa lomā, pēc spēlēšanas uzrādīja mazāk agresijas nekā tie, kuri spēlēja spēli agresīvā ložemetējnieka lomā. Kā arī tika noskaidrots, ka iesaistī̌sanās prosociālā lomā paaugstināja spēlētāju prosociālās spriešanas līmeni. Pētījuma hipotēzes apstiprinājās un pētījuma mērḳi tika sasniegti.
\end{abstract}

Atslègas vārdi: vardarbīgas datorspēles, prosociālas un agresīva lomas, agresija, prosociāla spriešana.

\section{Videogame Prosocial and Aggressive Role Playing Effects on Youths' Anger and Prosocial Reasoning}

\author{
Mihails Limonovs and Sandra B. Sebre \\ University of Latvia
}

\begin{abstract}
The goal of this study was to examine if youths who engage in videogame playing while taking on a prosocial role would report lower feelings of anger and higher ratings of prosocial reasoning that youths who engage in videogame playing while taking on an aggressive role. In order to reach this goal included in the study were 46 university students who randomly were assigned to one of two groups: participants who engaged in playing a violent video game taking on an aggressive role as a machine gunner $(n=23)$; and participants who engaged in playing the violent video game taking on a prosocial role as a combat medic $(n=23)$. Participants were
\end{abstract}

1 Corresponding author: Sandra Beatrice Sebre, University of Latvia, Jurmalas gatve 76, Riga LV-1083, Latvia. Email: sandra.sebre@lu.lv 
26 women and 20 men, aged from 19 to 27 years, mean age 22,24 years $(S D=2,11)$. As a measure of anger the participants completed the The State Trait Anger Expression Inventory (Spielberger, 1999). As a measure of prosocial reasoning they completed the Objective Measure of Prosocial Moral Reasoning (Gustavo, Eisenberg, \& Knight, 1992). The study results showed that those participants who played while engaged in the prosocial role of combat medic, directly following the game playing reported lower ratings of anger and aggression than those who had played while engage in the aggressive machine gunner role. Results also showed that engagement in the prosocial role led to higher ratings of prosocial reasoning. The hypotheses of the study were confirmed, and the goal of the research was reached.

Keywords: violent videogames, prosocial and aggressive roles, anger, prosocial reasoning.

Mūsdienu sabiedrība un tehnologiskais progress ir jau savstarpēji saistīti jēdzieni, mēs nevaram iedomāties savu ikdienas dzīvi bez tehnoloǵijām. Tehnologijas ir izmainījušas veidu, kā mēs strādājam, domājam un komunicējam viens ar otru. Tehnologijas ir izmainījušas arī veidu, kā mēs izklaidējamies. Datorspēl̦u spēlēšana šajā gadsimtā ir jauna nodarbošanās, kā bērni, pusaudži, jaunieši, pieaugušie un pat seniori pavada savu brīvo laiku. Datorspēḷu popularitāte arvien pieaug. Pētījums pirms dažiem gadiem uzrādīja, ka 91\% no amerikāṇu bērniem spēlē datorspēles (NPD Group, 2011). Latvijā veiktajā pētījumā saistībā ar datorspēlēm 84\% no vidusskolēniem norādīja, ka viņi lieto internetu datorspēl̦u spēlēšanai (Sebre, Bite, \& Miltuze, 2011). Kad datorspēles sākotnēji parādījās, tās spēlēja pārsvarā bērni, bet tagad datorspēḷu mērḳauditorija ir arī jaunieši un pieaugušie, jo ASV 30\% no datorspēlētājiem ir 18-35 gadus veci, un vidējais datorspēlētāja vecums ir 35 gadi (Entertainment Software Association, 2015).

Datorspēlu popularitāte turpina izraisīt jautājumus par datorspēlu ietekmi. Daudzi pētnieki ir pievērsušies vardarbīgām datorspēlēm un to potenciālai ietekmei uz spēlētājiem. Atkārtoti pētījumi rāda, ka vardarbīgas datorspēles var veicināt spēlētāju dusmu un agresijas paaugstināšanos (Wallenius, Punamaki, \& Rimpela, 2007; Anderson et al.,2010; Anderson, 2016). Lìdz galam nav izpētīts - vai vardarbīgo datorspēlu spēlēšana var beigties ar vardarbību reālajā dzīvē, tomēr pētniekiem ir vienots viedoklis par to, ka datorspēles dod iespēju iemācīties dažādus agresīvas uzvedības veidus. N̦emot vērā to popularitāti jauniešu vidē, ir svarīgi saprast, tieši kāda negatīva ietekme ir vardarbīgām datorspēlēm un kā to varētu samazināt vai likvidēt.

Vienlaicīgi jāṇem vērā, ka kopš pirmām videospēlēm 1970 gados, ir notikusi video un datorspēḷu evolūcija, un tās ir kḷūvušas daudz komplicētākas nekā sākotnējos gados - gan pēc satura, gan pēc formas. Tagad ne visās spēlēs ir skaidrs, kurš ir pozitīvais varonis un kurš ir negatīvais nelietis, pie tam vairākās vardarbīgajās datorspēlēs pastāv arī prosociālie elementi (darbs komandā, palīdzība citiem, cilvēku glābšana utt.). Lìdz ar to līdz galam nav skaidrs, kāda ietekme būs šādām daudzpusīgām datorspēlēm.

Datorspēles var iedalìt vardarbīgās, prosociālās un neitrālās spēlēs. Parasti neitrālas spēles ir saistītas ar izziṇas darbības attīstību, tās bieži izmanto, lai veicinātu noteiktas iemaņas, piemēram, ātru skaitǐšanu, valodas prasmes, abstrakto domāšanu utt. Prosociālām datorspēlēm ir izteikts prosociāls elements sižetā vai/un mehānikā, piemēram, àtrās palīdzības simulators būs izteikta prosociāla spēle. Savukārt 
vardarbīgām datorspēlēm mehānika un sižets ir tieši saistīts ar agresiju un vardarbību, piemēram, datorspēlē "Twisted Metal” galvenajam varonim ir jānogalina visi savi pretinieki, lai iegūtu balvu. Līdzīgi kā ar datorspēḷu žanriem, viena datorspēle var ietvert sevī gan vardarbīgus, gan prosociālus, gan neitrālus elementus. Kopumā pastāv vairāk nekā 20 datorspēḷu žanri, kuri būtiski atšḳiras ar mehāniku, mērḳiem un vēstījumu. Turklāt datorspēl̦u žanri var kombinēties, un vienai datorspēlei varētu būt dažādi žanri, piemēram, šaušanas spēle ar prosociālu lomu spēlēšanas elementiem vai stratēǵiska spēle ar puzles elementiem.

Neskatoties uz to, ka datorspēles visvairāk tiek izmantotas kā izklaides veids, tās izmanto arī daudzas organizācijas un iestādes, jo tām ir būtisks potenciāls veicināt noteiktas kognīcījas un noteiktu uzvedību. Ir zināms, ka ASV armijā datorspēles tiek izmantotas kā daḷa no mācī̌sanās programmas, lai attīstītu tādas iemaṇas kā braukšana ar tanku, karaspēka komandēšana, lidošana un kauja. Vardarbīga datorspēle "Doom" ir bijusi modificēta un izmantota, lai trenētu jūras kājnieku komunikācijas prasmes un prasmes strādāt komandā (Buckley \& Anderson, 2006), savukārt daudzi skolotāji mūsdienās izmanto datorspēles, lai veicinātu skolēnu akadēmiskās prasmes, to starp algebras un ǵeometrijas principu apguvi (Buckley \& Anderson, 2006). Speciālas izglītojošas datorspēles tiek izmantotas, lai cilvēki ar garīgu atpalicību varētu mācīties, kā orientēties un iepirkties lielos veikalos. Vienlaicīgi datorspēlēm pastāv arī nekontrolējami blakusefekti. Šie efekti varbūt pozitīvi, piemēram, uzlabotas problēmu risināšanas spējas (Adachi \& Willoughby) un labākas uztveres spējas (Green \& Bavelier, 2012), vai arī negatīvi efekti kā paaugstināta agresivitāte (Anderson et al., 2010) un datorspēlu atkarība (Gentile, 2009). Tieši šiem nekontrolējamiem blakusefektiem, it īpaši agresivitātei un vardarbīgai uzvedībai, sabiedrība pievērš vislielāko uzmanību.

\section{Datorspēḷ ietekme uz spēelētāju: Vispārējā iemācǐ̌sanās modeḷa redzējums}

Viens no vadošajiem ASV pētniekiem saistībā ar datorspēlı potenciāliem negatīviem efektiem Kreigs Andersons (Craig Anderson) kopā ar kolēgeiem ir izstrādājis Vispārējo agresijas modeli (angl. - General Agression Model) (Anderson \& Bushman, 2002; Anderson, 2016), kas norāda uz procesiem, kā vardarbīgās datorspēles varētu ietekmēt spēlētāju domas un uzvedību. Šis modelis skaidro saikni starp saskarsmi ar vardarbīgu datorspēles saturu un cilvēku agresiju, un šo modeli izmanto, lai izskaidrotu agresijas attīstību datorspēḷu spēlētājiem. Vispārējais agresijas modelis apraksta daudzpakāpju procesu, kurā individuālie un situatīvie faktori (piemēram, vardarbīgu datorspēḷu spēlēšana) aktivizē un ietekmē cilvēka kognitīvos, afektīvos un fizioloǵiskos procesus - kas, savukārt, noved pie agresīvas uzvedības. Tomēr, n,emot vērā, ka ne visas datorspēles ir vardarbīgas, Andersons ar kolēǵi Bakliju (Buckley) paplašināja un vispārināja šo teorētisko modeli, lai tas varētu atspoguḷot procesu, kā jebkura datorspēlu spēlēšana ietekmē domašanu un uzvedību. Šo paplašināto teorētisko modeli nosauca par Vispārējo iemācīšanas modeli (angl. - General Learning Model) (Buckley \& Anderson, 2006). Galvenais princips ir tāds, ka no datorspēlēm var mācīties, un atkarībā no spēles satura (piem., vardarbīga vai prosociāla sižeta) spēles gaitā spēlētājam attīstās jaunas un aktivizējas jau esošās kognitīvās shēmas, un pēc tam tās var vadīt spēlētāja uzvedību.

Izstrādājot Vispārējo agresijas modeli (VGM) un Vispārējo iemācīšanas modeli (VIM), to autori pamatojās uz sociālo iemācīšanās teoriju un sociālo izziņas teoriju 
(Bandura, 1971; Buckley \& Anderson, 2006). Vispirms tiek piemērots Banduras izvirzītais pamatprincips, ka cilvēks var iemācìties uzvedību, novērojot vai atdarinot citu cilvēku uzvedību un konstatējot tās sekas. Spēlējot datorspēles, spēlētāji nepārtraukti novēro un iesaistās spēles protagonista darbībā un attieksmēs, kā arī datorspēles ir izveidotas tādā veidā, ka vienmēr var redzēt savas uzvedības (spēles panākuma) sekas. Sekojot šim principam, datorspēles ir ar spēju veicināt jaunas uzvedības apguvi.

Baklija un Andersons uzsver, ka datorspēles ir ne tikai labi, bet pat lieliski skolotāji, par to liecina to spēja uz ilgāku laiku pievērst spēlētāju uzmanību, kā arī datorspēles dod iespēju spēlētājam justies kompetentam par savu izdarīto darbu, tās dod iespēju aktīvi piedalīties procesā nevis pasīvi novērot, tās rāda spēlētājam visus nepieciešamos soḷus, lai veiktu noteiktu uzvedību (Buckley \& Anderson, 2006). Turklāt datorspēles ir motivējošas, jo spēlētājam ir kontrole pār notikumiem, viņš(a) var regulēt spēles grūtību pakāpi attiecībā uz savām personīgajām spējām. Datorspēles sniedz spēlētājam konkrētas un tūlìtējas atgriezeniskās saites (slavēšana ar punktiem, bonusiem utt.) par noteiktām pūlēm, kuras spēlētājs ir veicis; tas savukārt motivē spēlētāju atkārtot noteiktu uzvedību un veicina viņam(ai) pozitivvu attieksmi pret spēles saturu (Buckley \& Anderson, 2006).

Andersons un Baklija apraksta daudzpakāpiena procesu, kas iekḷauj pamatprincipus no sociālās izziņas teorijas - kā datorspēḷu spēelěšana aktivizē jau esošās kognitīvās shēmas, tās nostiprina vai arī veicina jaunu kognitīvo shēmu vai pārliecību attīstību, un kā tas kopumā ietekmē turpmāko uztveri, interpetācijas un uzvedību (skat. 1. attēlu).

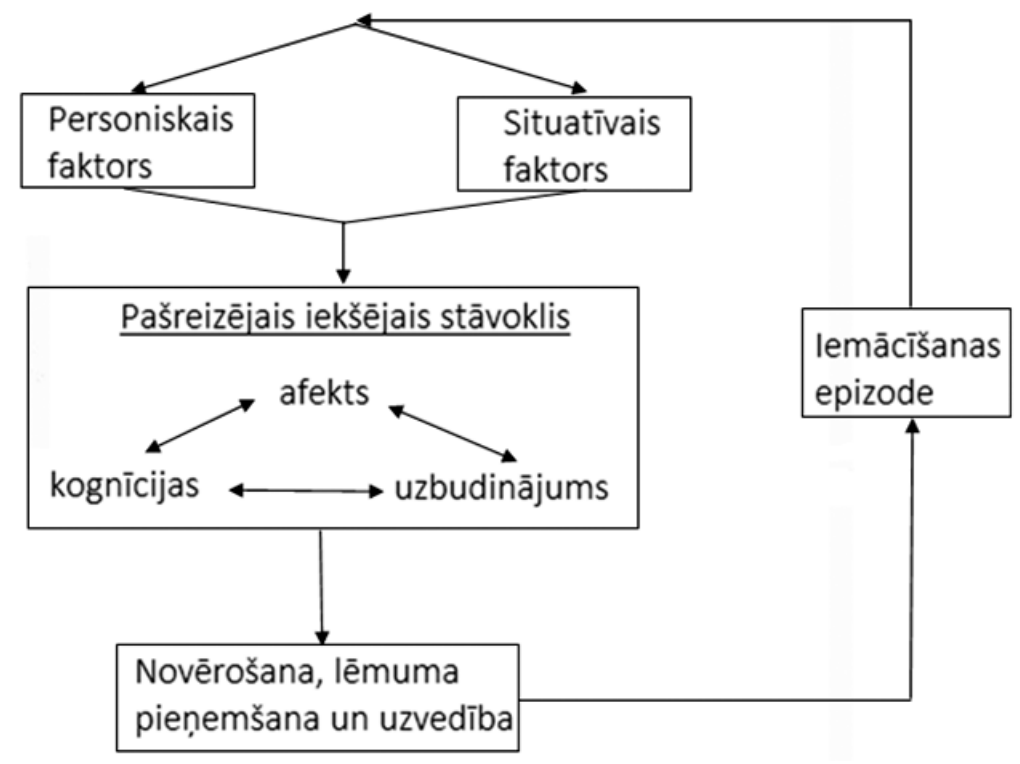

1. attēls. Vispārīgais iemācīšanas modelis - vienkāršots skats (Buckley \& Anderson, 2006)

Šis teorētiskai modelis norāda, ka indivīda personiskie faktori mijiedarbībā ar situāciju, kurā viņš(a) atrodas noteiktajā laikā, ietekmē viṇa pašreizējo iekšējo stāvokli 
(viņa kognīcijas, emocijas un fiziologiiskās reakcijas), kas savukārt ietekmē cilvēka uzvedību (Buckley \& Anderson, 2006). Šajā modelī pie personiskiem faktoriem ir pieskaitīts indivīda dzimums, vecums, intelektuālās un socioemocionālās spējas un prasmes, attīstîbas vēsture, uzskati, attieksme, mērḳi, uzvedības tendences un iepriekšèjā pieredze. Savukārt situatīvie faktori ir apkārtējās vides apstākḷi - pati situācija, apkārt esošie cilvēki, vides ìpašîbas un, visbūtiskākais šajā modelī - datorspēḷu saturs un forma. Pastāv noteikti personiskie faktori, kuri ir ìpaši nozīmīgi saistībā ar datorspēlēm, piemēram, agresīvi uzskati un vērtības, dzimums (vīriešiem ir lielāka varbūtība agresīvi reageèt, spēlējot datorspēlas), prosociāla tendence palīdzēt citiem utt. Svarīgi situatīvie faktori ir datorspēles spēja noturēt spēelētāja interesi, datorspēles saturs (prosociāls, neitrāls, vardarbīgs) un laiks, kas pavadīts, spēlējot datorspēli. Starp situatīivajiem un personiskajiem faktoriem notiek mijiedarbïba, piemēram, vardarbīgas datorspēles saturs varētu vairāk ietekmēt tos indivīdus, kuri jau ir ar agresīvām raksturīpašībām (Gitter et al., 2013).

Būtiska loma šajā teorētiskajā modelī ir indivīda domām, viṇa kognīcijām, kognitīvām shēmām vai zināšanu struktūrām (angl. - knowledge structures), kas ietver viņa pārliecības, uzskatus un uzvedības scenārijus (angl. - bihevioral scripts). Uzvedības scenārijs ir kognitīva shēma par to, kāda ir tipiskā uzvedības secība vai notikuma gaita kādā noteiktā situācijā, piemēram, kā uzvesties un ko sagaidīt restorānā. Tipiski uzvedības scenāriji attīstās, balstoties uz atkārtotu pieredzi noteiktā situācijā, un tie ietver izpratni par cēloṇsakarībām, mērḳiem un rīcības plāniem. Andersons min, ja bērns ir atkārtoti vērojis simtiem piemēru, ka uz aizvainojumu reaǵē ar fizisku ietekmēšanu, tad viņam visticamāk veidosies agresīvs uzvedības scenārijs saistībā ar aizvainojumiem (Anderson \& Bushman, 2002). Pēc sociālās izziņas teorijas, situatīivie faktori var aktivizēt noteiktus scenārijus, kuri var noskaņot/ietekmēt indivīda situācijas interpretāciju un iespējamo atbildes reakciju uz šo situāciju. Jo situācija ir pazīstamāka, jo lielāka varbūtība, ka aktivizēsies attiecīgais scenārijs. Situatīviem faktoriem ir spēja aktualizēt un nostiprināt attiecīgas zināšanu struktūras, piemēram, agresīvie stimuli aktualizē zināšanu struktūras, kas ir saistīts ar zināšanām par agresiju. Ilglaicīgas sekas var rasties, ja cilvēks atkārtoti aktivizē vienas un tās pašas zināšanu struktūras, jo tas veicina zināšanu struktūru automātisku aktivizāciju (Buckley \& Anderson, 2006).

Personiskie un situatīvie faktori arī var ietekmēt emocijas un garastāvokli, afektīvo stāvokli, kas var savukārt ietekmēt jaunu kognīciju rašanos. Šo procesu var skaidrot ar diviem procesiem: garastāvoklim-atbilstošas-kognīcijas (angl. - mood-congruent cognition) un sistemātiskais desensitizācijas process (angl. - systematic desensitization). Garastāvoklim-atbilstošu-kognīciju procesa gadījumā cilvēka garastāvoklis palielina afektīvi līdzīgas informācijas apstrādi. Tātad, ja cilvēks ir pozitīvi un prosociāli noskaṇots, viņš veiksmīgāk pārstrādās prosociālu informāciju, kā arī šì informācija ilgāk paliks viña apziṇā (Buckley \& Anderson, 2006). Savukārt sistemātiska desensitizācija ir process, kad atkārtota saskarsme ar sakontēji drausmīgiem un nepatīkamiem stimuliem, kas iekḷauti pozitīvā kontekstā (piem., vardarbība jautrā datorspēè), noved pie negatīvo emociju samazināšanās attiecībā uz šiem stimuliem. Citiem vārdiem, cilvēks, kurš daudz spēelē vardarbīgas datorspēles, var pierast pie agresijas un skatīties uz agresīvām domām kā uz kaut ko normālu. 
Gan vardarbīgo, gan nevardarbīgo datorspēl̨u spēelěšanai ir tendence radìt fiziologiskas reakcijas, ko var apzīmēt arī kā psiholog̣isku uzbudinājumu (angl. - arousal) (Buckley \& Anderson, 2006). Vardarbīgām datorspēlēm ir lielāka tendence veicināt šādas fiziolog̣iskas reakcijas vai uzbudinājumu (Anderson et al., 2010).

Ir svarīgi saprast, ka iekšējo stāvokḷa dažādie komponenti var ietekmēt viens otru, piemēram, kognīcijas un fizioloğiskās reakcijas var ietekmēt afektīvo stāvokli, savukārt afektam ir ietekme uz kognitīvām un fiziologiskām reakcijām (Buckley \& Anderson, 2006). Naidīgas domas vai dusmas var iespaidot cilvēku izmantot noteiktas kognitīvas shēmas vai scenārijus, lai plānotu savu turpmāko darbību un uzvedību. Iekšējais stāvoklis (aktivizētās kognīcijas, afekts un fiziolog̣iskās reakcijas) dotajā brīdī ietekmē novērtēšanas un lēmuma pieņemšanas procesus.

VIM postulē, ka atkārtota datorspēlu spēelěšana var veicināt vairākas ilglaicīgas izmaiņas, jo tā aktivizē un pastiprina jau esošās kognitīvās struktūras ar līdzīgu saturu, kā arī rada pamatu veidot jaunas zināšanu struktūras, jaunus problēmu risinājumus, jaunus scenārijus vai plānus, kā uzvesties un reaǵêt dažādās situācijās (Buckley \& Anderson, 2006).

Apkopojot informāciju par VIM, datorspẹ̄u spēlēšana iedarbojas uz cilvēka iekšējo stāvokli, kas savukārt ietekmē viņa novērtēšanas un lēmuma pieņemšanas procesus. Datorspệ̣u saturs ir nozīmīgs, jo tas aktivizē noteiktas zināšanu struktūras, kuras var iespaidot cilvēka situācijas uztveri. Ar laiku attiecīgās zināšanu struktūras var pastiprināties un aktivizēties automātiski, kā arī ir iespējams iemācīties pavisam jaunas zināšanas. Šim procesam palīdz afektīvās stāvokḷa izmaiņas, jo bieži vien datorspēles izraisa stipras emocijas, kas labvēligi ietekmē informācijas saglabāšanu. Fizioloǵiskām reakcijām kopā ar izziņas procesiem ir ietekme uz afektīvo stāvokli. Protams, ietekmes stiprums ir atkarīgs no situātīviem faktoriem (spēles spēja ieinteresēt, saturs) un no cilvēka personiskajiem faktoriem (jau esošās attieksmes, predispozīcijas). Tātad, Baklijas un Andersona teorētiskais modelis norāda, ka datorspẹ̄̂ spēlēšanas laikā cilvēkam notiek izmaiṇas kognitīvajā un emocionālajā stāvoklī.

\section{Prosociālas datorspēles: prosociālas uzvedības veicināšana}

Neskatoties uz to, ka pastāv daudzi pètījumi, kas aplūko vardarbīgu datorspēḷu spēlēšanu, pētijumu par prosociālām datorspēlēm un to ietekmi ir salīdzinoši maz. Tomēr relatīvi nesen psiholoğijas pētnieki ir sākuši pievērst uzmanību šai tēmai. Vadoties pēc VIM, prosociālām datorspēlēm atšķirībā no spēlēm ar vardarbīgo saturu vajadzētu aktivizèt prosociālas kognicijas un pozitīvas emocijas. Lai to pārbaudītu, Salīms (Saleem) ar kolēgiem izveidoja eksperimentālu pētījumu ar mērḳi noskaidrot prosociālo datorspēlu efektu uz skolas vecuma bērnu palīdzošu un kaitniecisku uzvedību, salīdzinot to ar vardarbīgo un neitrālo datorspẹlu spēlēšanas efektiem (Saleem, Anderson, Douglas, \& Gentile, 2012). Pētnieki arī izmērīja dalībnieku agresivitātes predispozīiju (angl. - trait agression), lai zinātu, kuriem bērniem ir tendence izvairīties no izpalīdzīgas uzvedības un izvēelèties kaitējošu uzvedību. Pēc tam katram bērnam individuāli tika piedāvāta konkrēta datorspēle ar vardarbīgu, neitrālu vai prosociālo saturu. Rezultātā bērni, kuri spēelēja prosociālo datorspēli, izrādīja palīdzošu uzvedību ievērojami vairāk nekā bērni, kuri spēèeja neitrālu vai vardarbīgu datorspēli - tādā veidā 
parādot, ka datorspēlei bija ietekme uz bērnu uzvedību (Saleem, Anderson, Douglas, \& Gentile, 2012).

Iegūto rezultātu var skaidrot ar VIM teoriju - datorspēl̦u prosociālais saturs īslaicīgi ietekmēja respondentu iekšējo stāvokli - aktivizēja prosociālas kognīcijas un emocijas, kas ir saistītas ar palīdzošu uzvedību, un tas, savukārt ietekmēja dalībnieku prosociālo uzvedību. Tagad vēl nav īsti zināms, vai šis efekts var izpausties ilgtermiṇā, jo pietrūkst longitudinālu pētījumu šajā jomā, tomēr teorētiski pēc VIM tas ir iespējams.

\section{Prosociālas datorspēles: agresijas samazināšana}

Pētījumi rāda, ka prosociālu datorspēl̦u spēlēšana var mazināt agresiju. Greitemejera un kolēgu (Greitemeyer, Agthe, Turner, \& Gschwendtner, 2011) eksperimentālajos pētījumos ar universitātes studentiem tika novērota reakcija uz provocējošiem stimuliem. Tika sagaidīts, ka prosociālo datorspēl̦u spēlēšana samazinās agresīvo uzvedību, negatīvi ietekmējot dalībnieku agresīvās kognīcijas un negatīvo afektu. Dalībnieki tika nejauši sadalīti trīs grupās, kur viṇi spēlēja prosociālu, vardarbīgu vai neitrālu datorspēli. Vispirms pētījuma dalībnieki spēlēja datorspēles, pēc tam viṇus apvainoja, un pēc tam viņiem bija iespēja agresīvi reaǵēt uz apvainojumu. Rezultāti rādīja, ka tie dalībnieki, kuri spēlēja vardarbīgo datorspēli, izmantoja agresīvāku uzvedību pret "partneri" un darīja to vairāk nekā tie, kuri spēlēja neitrālo datorspēli. Savukārt, dalībnieki, kuriem piedāvāja spēlēt prosociālo datorspēli, uzvedās mazāk agresīvi nekā tie, kuri spēlēja neitrālo spēli. Otrais eksperiments pēc sava dizaina bija līdzīgs pirmajam, tomēr šoreiz tika kontrolētas dalībnieku kognīcijas un emocijas ar mērḳi uzzināt to lomu šajā procesā. Rezultāti norādīja, ka prosociālām datorspēlēm bija ievērojama ietekme gan uz kognīcijam, gan uz afektīvo stāvokli, salīdzinot ar neitrālām datorspēlēm. Prosociālās datorspēles samazināja agresīvās kognīcijas un veicināja pozitīvas emocijas, kas savukārt ietekmēja dalībnieku uzvedību. Uzlabotais afekts mazināja netiešo agresiju, bet pozitīvās kognīcijas mazināja tiešo agresiju.

\section{Vardarbīgas datorspēles: tiešas un netiešas agresijas veicināšana}

Viens no galvenajiem vardarbīgo datorspēḷ efektiem, kuram tiek pievērsts daudz uzmanības, ir agresīvo domu kultivēšana un līdz ar to agresijas veicināšana. Daudzi pētījumi ir norādījuši, ka vardarbīgām datorspēlēm ir potenciāls izraisīt agresīvu uzvedību. Tomēr nesen tika atklāts, ka datorspēles var izraisīt ne tikai tiešo, bet arī netiešo agresiju. Valleniusa un kolēǵu (Wallenius et al., 2007) pētījums norāda uz to, cik būtiski ir individuālie un situātīvie faktori, kad runa ir par saikni starp datorspēlu vardarbību un agresiju. Autori raksta, ka viṇu pētījuma mērķis bija izskatīt saistības starp datorspēlı spēlēšanu un tiešo un netiešo agresiju bērniem, kā arī analizēt, kā individuālie faktori (sociālais intelekts, vecums) un situatīvie faktori (bērnu-vecāku konflikti) var tos ietekmēt.

Pētnieki atklāja saistību starp datorspēles vardarbības līmeni un agresiju visiem bērniem, bet zēnu izlasē vardarbīgo datorspēḷu spēlēšana korelēja ar tiešu agresiju, savukārt meiteṇu izlasē ar netiešu agresiju. Arī rezultātos bija redzams, ka vecāku-bērnu komunikācijai un sociālajam intelektam ir mediatoru loma agresijas izpausmēs. Netiešās 
agresijas izpausmes bija vairāk raksturīga pusaudžiem ar augstu sociālo intelektu, un negatīva vecāku-bērnu komunikācija bija saistīta ar tiešas agresijas izpausmi. Pētijuma rezultāti ir saskaņā ar Vispārējo iemācišanas modeli - bērniem, kas vairāk spēlēja vardarbīgas datorspēles, bija lielāka varbūtība iesaistīties agresīvā uzvedībā, jo atkārtotas iedarbïbas dēl kognīcijas, kas ir saistītas ar agresiju, varēja nostiprināties un līdz ar to ietekmēt uzvedību.

\section{Vardarbīgas datorspēles: prosociālas uzvedības samazināšana}

Pētnieki ir atklājuši, ka datorspēlēm ar vardarbīgu saturu pastāv tendence ne tikai veicināt agresīvu uzvedību, bet arī tendence samazināt prosociālo uzvedību. Andersona 2010. gada metaanalīzē, kurā tika apkopoti 136 pētījumi ar mērḳi noskaidrot galvenos vardarbīgo datorspẹ̄̂u efektus, tika norādīts, ka vardarbīgu datorspēḷu spēlēšana būtiski samazina palīdzošu jeb prosociālu uzvedību (Anderson et al., 2010). Šis rezultāts bija raksturīgs visiem metaanalīzē iekḷautajiem pètījumiem, neatkarīgi no pētījuma metodes - palīdzēt citam izpildìt uzdevumu, palīdzēt "upurim" incinētā vardarbỉbas epizodē, ziedot naudu, u.c. Metaanalīze norādīja, ka pētijuma dizainam bija būtiska loma: eksperimentālos pētỉjumos šis efekts bija vislielākais, bet longitudinālos pētījumos efekts bija vismazākais. Vēl viens svarīgs atzinums, kas tika iegūts no metaanalīzes, bija tas, ka dzimumam nebija statistiski nozīmīgas ietekmes uz rezultātiem. Metaanalīzes autori secina, ka prosociālas uzvedības samazinājumu var izskaidrot ar diviem faktoriem: 1) empātijas samazināšanās un 2) desensitizācija pret vardarbību. Autori uzskata, ka agresīvo kognīciju pieaugums kavē empātiskas domas un jūtas, kas ir palīdzošas uzvedības pamats. Līdzīgi desensitizācija pret vardarbību var kavēt palīdzošu uzvedību, kas būtu vērsta uz vardarbības upuri (Anderson et al., 2010).

\section{Vardarbīgas datorspēles ar prosociāliem elementiem}

Ja ar vardarbīgām datorspēlēm un to iedarbību saistībā ar agresiju ir daudz jau izpētīts un pierādìts, tad pētỉjumos par vardarbīgām datorspēlēm ar prosociālo saturu vai elementiem viss ir sarežgîtāk, jo mūsdienīgās datorspēles ir kḷuvušas daudz komplicētākas nekā to priekšgājēji. Ir izmainījies ne vien to mehānika, dizains un grafiskais noformējums, bet arī to stāstījums. Ja datorspẹlu vēstures sākumā pārsvarā to sižets bija diezgan vienkāršs, tad mūsdienās tas ir kḷuvis komplicēts. Tagad pat daudzās vardarbīgās datorspēèès var saskatìt prosociālus elementus saturā vai spēles mehānikā. Piemēram, populārākajās datorspēlēs galvenā varoṇa vardarbīgas darbības tiek attaisnotas ar globāliem prosociāliem mērḳiem - karš pret teroristiem, tēvzemes aizsardzība, cilvēces glābšana. Vadoties pēc VIM, prosociālām un vardarbīgām datorspēlēm varētu būt savstarpēji izslēdzoši efekti - prosociālas uzvedības veicināšana un agresijas mazināšana; vai arī agresīvas uzvedības veicināšana un prosociālas uzvedības mazināšana. Pēc VIM - vardarbīgām datorspēlēm ar prosociāliem elementiem vajadzētu vienlaikus aktivizēt gan agresīvas, gan prosociālas kognīcijas. Līdz ar to rodas jautājums - kāda ietekme būs šàda tipa spēlēm?

Ir vairāki veidi, kā var skaidrot prosociālo elementu ietekmi uz vardarbīgo datorspēẹu spēlēšanu un agresiju. Spēles prosociālais konteksts var ietekmēt spēlētāja vardarbīgo elementu uztveri (Gitter et al., 2013). Ir arī iespējams, ka aktivizētās 
prosociālās kognīcijas konkurē ar agresīvām kognīcijām, lai iegūtu spēelētāja uzmanību. Teorētiski var pieņemt, ka, salīdzinot ar viennozīmīgi vardarbīgām datorspēlēm, vardarbīgas datorspēles ar prosociāliem elementiem samazinās agresīvas uzvedības varbūtỉbu spēlētājiem. Tieši šo pieņēmumu pārbaudīja Gitters un kolēgi (Gitter et al., 2013). Viṇi izvirzīja hipotēzi, ka vardarbīgu datorspēlu, kurās galvenajam varonim ir prosociāli nolūki, spēlēšana izraisīs mazāk agresijas nekā vardarbīgu spẹ̄̂u bez šāda veidā attaisnojuma spēlēšana. Pētījuma dalībniekiem tika piedāvāts spēlēt vienas vardarbīgas datorspēles atškirīgas versijas. Abas versijas bija ar līdzīgu spēles mehāniku, grafiku un vardarbības līmeni, tomēr pirmajā versijā spēlētājus instruēja palīdzēt savam virtuālajam partnerim (palīdzēt sasniegt viņa mērḳus, aizsargāt viṇa dzīvību, nogalinājot pretiniekus), bet otrajā versijā spēles varonim nebija prosociāla uzdevuma, dalībniekiem tika pateikts, ka viṇu uzdevums šajā spēlē ir nogalināt pēc iespējas vairāk pretinieku. Pētijuma hipotēze apstiprinājās - dalībnieki, kuri spēlēja vardarbīgo datorspēli ar prosociālo elementu, izrādīja ievērojami mazāk agresijas nekā tie dalībnieki, kuri spēlēja viennozīmīgi vardarbīgo datorspēli. Interesanti, ka otrajā pētỉjumā ar līdzīgu dizainu tika atklāts, ka vardarbīgas spēles ar prosociālo kontekstu padarija prosociālas kognīcijas pieejamākas (Gitter et al., 2013). Šie atklājumi potenciāli var norādīt uz to, ka kognīciju veidi, kas tiks aktivizēti un izsaukti, būs atkarīgi no datorspēles elementu kopuma.

Prosociālais elements var pastāvēt ne tikai spēles saturā, bet arī spēles mehānikā. Piemēram, ir vardarbīgas kooperatīvas datorspēles, kur spēlētājiem jāsadarbojas kopā ar citiem un jārūpējas par saviem partneriem (virtuāliem vai reāliem), lai veiksmīgi izturētu spēles izaicinājumus. Pārsvarā tādas spēles stipri motivē palīdzēt un rūpèties par savu partneri vai partneriem, jo veiksmīgi izspēelèt tādas spēles nesadarbojoties ir l’oti grūti vai vispār neiespējami. Nesen publicēts eksperimentāls pētijums pārbaudīja, kāda ir ietekme, ja spēlētāji spēlē kooperatīvi, sadarbojoties viens ar otru. Džerebeka un Fergusons (Jerabeck \& Ferguson, 2013) sadalīja dalībniekus sešās grupās: vardarbīgas, prosociālas vai neitrālas datorspēles spēelěšana; katrā variantā dalībnieks spēlēja individuāli vai sadarbībā ar partneri. Rezultāti uzrādỉja, ka spēlētāji, kuri spēlēja kooperatīvi, neatkarīgi no datorspēles vardarbības līmeņa, pēc spēlěšanas uzrādīja ievērojami mazāk agresīvas uzvedības. Var pieņemt, ka arī šajā gadījumā prosociālas kognīcijas konkurēja ar agresīvām kognīcijām. Ir iespējams, ka spēles konteksts (kooperatīvais režìms) pats par sevi var būt par būtisku prosociālo elementu, jo tas samazināja agresiju arī neitrālo un prosociālo spẹlu gadījumā. Pētnieki secināja, ka ne tikai datorspēles saturs, bet arī to konteksts ir l̦oti svarīgs saistībā ar uzvedības izpausmēm (Jerabeck \& Ferguson, 2013).

Pētijumos ir redzams, ka mūsdienīgās datorspēlēs vardarbīgais elements neizslēdz prosociālos elementus, savukārt prosociālais elements ir spējīgs samazināt vardarbīgas datorspēles negatīvu ietekmi uz agresiju. Lìdzšinējie pētījumi norāda, ka datorspēḷu saturs ir saistīts ar to ietekmi uz spēlētāju. Vadoties pēc Baklijas un Andersona VIM teorētiskā model̦a, varam postulēt, ka datorspēḷu spēlēšana izraisa izmaiņas indivīda iekšējā stāvoklī (kognīcijās, emocijās un fiziologiskās reakcijās), kas savukārt ietekmē cilvēka tūlītējo uzvedību. Kognitīvajā līmenī datorspēles aktivizè, aktualizē un papildina zināšanu struktūras vai kognitīvās shēmas. Lìdzšinējo pētījumu rezultāti rāda, ka datorspēles saturs ir saistīts ar spēlētāju kognitīvo reakciju, kas savukārt ir saistīta ar uzvedības izpausmēm - vardarbīgas datorspēles paaugstina agresijas varbūtību, bet 
prosociālas spēles veicina prosociālās izpausmes. Tomēr ir bijuši maz pētijumu par datorspēlēm, kas ietver gan vardarbību, gan prosociālus elementus, bet tie, kas ir bijuši, norāda, ka prosociālais elements spēles sižetā vai mehānikā var samazināt agresijas izpausmes un veicināt prosociālas izpausmes.

Lai pilnīgāk izprastu mūsdienu datorspēḷu, kuras ir gan ar vardarbīgiem, gan ar prosociāliem elementiem, ietekmi, ir nepieciešami pētījumi ar šìm jaunām neviennozīmīgām spēlēm. Šādi pētỉjumi varētu pastiprināti ierosināt datorspẹ̄̂u dizainerus iesaistīt prosociālus elementus vardarbīgajās spēlēs, lai samazinātu to negatīvo ietekmi.

Šajā pētijumā tika pārbaudītas divas hipotēzes:

1. Jaunieši, kuri spēlē vardarbīgu datorspēli ar prosociāliem elementiem, ieņemot prosociālu lomu, uzrādīs augstākus prosociālas izpausmes rādītājus nekā jaunieši, kuri spēlē vardarbīgu datorspēli ar prosociāliem elementiem, ien̦emot agresīvu lomu.

2. Jaunieši, kuri spēlē vardarbīgu datorspēli ar prosociāliem elementiem, ien̦emot prosociālu lomu, uzrādīs zemākus agresijas izpausmes rādītājus nekā jaunieši, kuri spēlē vardarbīgu datorspēles ar prosociāliem elementiem, ieņemot agresīvu lomu.

\section{METODE}

\section{Pētỉjuma dalíbnieki}

Pētijumā piedalījās 46 dalībnieki, universitātes studenti vecumā no 19 līdz 27 gadiem, kuriem ir bijusi iepriekšēja pieredze ar datorspẹ̄ı spēlēšanu (ir vismaz vienreiz iepriekš spēlējuši datorspēles). Pētījuma dalībnieki pārstāvēja abus dzimumus: piedalijās 26 sievietes un 20 vīrieši. Vidējais respondentu vecums bija 22,24 gadi $(\mathrm{SD}=2,11)$. Pētijuma dalībnieki tika sadalìti divās grupās pēc nejaušības principa, visi dalïbnieki spēlēja vienu un to pašu spēli. Pirmajā grupā jaunieši spēlēja datorspēli, ieņemot prosociālu lomu; otrās grupas dalībnieki spēelēja datorspēli, ieņemot agresīvu lomu. Pētījumā netika iekḷauti 4 cilvēki, kuri sākotnēji bija pieteikušas. Divi cilvēki bija vecāki par 29 gadiem, 1 cilvēks nepareizi aizpildīja aptaujas, un vienam dalībniekam nebija nekādas iepriekšějas pieredzes ar datorspēlēm.

\section{Instrumentārijs: Datorspēle un spēlētāju iespējamās lomas}

Eksperimentā tika izmantota datorspēle “Team Fortress 2" - daudzspēlētāju pirmās personas šaujamspēle. Šajā datorspēlē spēlētāji dalās divās komandās, katrā komandā ir dažādi varoṇi, kas pilda noteiktas funkcijas (piem., snaiperis, mediķis, karavīrs, inženieris utt.). Spēles mērḳis ir uzvarēt pretinieku komandu - iekarot viṇu bāzi, nogalināt visus pretiniekus, nosargāt savu bāzi. Tipiski spēlētājs var izvēlēties, kuru varoni viņšs(a) spēlēs.

Šajā pētijumā pètījuma dalībnieki pēc nejaušîbas principa tika sadalīti divās grupās. Pirmās grupas dalībnieki ien̦ēma mediḳa lomu (tālāk mediķu grupa) un otrā grupa ieņēma ložmetējnieka lomu (tālāk ložmetējnieku grupa). Ložmetējnieku grupas uzdevums bija nogalināt pēc iespējas vairāk pretinieku un iekārot pretinieku bāzi. Mediķu grupai bija prosociālais uzdevums - ārstēt savas komandas dalïbniekus kaujas 
laukā, lai tie varētu turpināt karot, tomēr viṇiem bija iespēja arī nogalināt pretiniekus, lai iekārotu viṇu bāzi. Katrs dalībnieks spēlēja savu individuālo spēles sesiju, vinu komandas dalïbniekus un pretiniekus kontrolēja dators.

\section{Instrumentārijs: Agresīvu izjūtu un prosociālās spriešanas aptaujas}

Pētijumā tika izmantotas divas aptaujas. Lai mērītu agresīvu izjūtu līmeni pirms un pēc datorspēḷ spēlēšanas, tika izmantota Dusmu pašnovērtējuma anketas Dusmu stāvokḷa skala (The State Trait Anger Expression Inventory, Spielberger, 1999). Aptauju Latvijā adaptēja I. Bremane (2005). Šì skala sastāv no 15 apgalvojumiem, kas veido trīs apakšskalas: Dusmu skala (5 apgalvojumi), piemēram, "Es jūtos īgns"; Verbālā agresija (5 apgalvojumi), piemēram, "Es jūtu vēlēšanos skalii lamāties"; un Fiziskā agresija (5 apgalvojumi), piemēram, "Es jūtu vēlēšanos iesist kādam". Atbildes tiek vērtētas Likerta-tipa skalā, kur 0- "nemaz", 1 - "drīzāk nē, nekā jā", 2 - "drīzāk jā, nekā nē" un 3 - "ḷoti”. Šì pētijuma ietvaros iekšèjās saskaņotības rādītājs dusmu skalai ir $\alpha=0,85$, verbālās agresijas skalai ir $\alpha=0,81$, fiziskās agresijas skalai ir $\alpha=0,78$. Aptauja paredz, ka tiek arī aprēḳināts kopējais Agresijas stāvoklis, šīs kopējās skalas ticamības koeficients ir $\alpha=0,90$.

Lai mērītu prosociālās domāšanas līmeni tika izmantots Prosociālas un morālās spriešanas mērijums (Objective Measure of Prosocial Moral Reasoning, Gustavo, Eisenberg, \& Knight, 1992). Šì aptauja tika adaptēta šì pētijuma ievāros sadarbībā ar S. Sebri un A. Miltuzi. Metode sastāv no trim stāstiem, un katrā stāstā varonim ir jāizvēlas, vai palīdzēt vai nepalīdzēt otram cilvēkam, kuram ir nepieciešama palīdzība, lai arī pašam tas būtu neizdevīgi. Respondentiem vajadzēja atzìmēt, kas būtu jādara stāsta varonim noteiktā situācijā ("palīdzēt", "nepalīdzēt", "nav pārliecināts"), un tad par katru situāciju atbildēt uz 7-9 jautājumiem, kas apraksta, kas palīdzēja viniiem pieṇemt attiecīgo lēmumu (piemēram, "Palīdzība šādās situācijās padara pasauli labāku"). Respondenti savus vērtējumus atzīmēja Likerta-tipa skalā (no 1 līdz 7). Vērtējumi tiek aprēḳināti piecās apakšskalās: hedonistiskā spriešana (t.i., "Vai Katrīna varēs atrast jaunajā skolā citus draugus"), uz atzinību orientētā spriešana (t.i., "Vai Pētera draugi un vecāki pozitīivi novērtēs to, ko viņš dara"), stereotipiskā spriešana (t.i.,. "Palīdzēt bērniem invalīdiem ir pareizā lieta, ko darìt"), uz vajadzībām orientētāa spriešana (t.i., "Izprast, cik nopietna ir zēna slimība"), internalizētā prosociālā spriešana (t.i., "Vai Katrīna dara to, ko viṇa uzskata par pareizāko rīcību”). Hedonistiskās spriešanas skala un Uz atzinību orientētās spriešanas skala tiek izskatìtas kā pirmā līmeņa prosociālā spreišana, un to kopējais $\alpha=0,79$. Stereotipiskā spriešana, Uz vajadzībām orientētā spriešana, un Internalizētā prosociālā spriešanas tiek uzskatìta par otrā un trešā līmeņa prosociālo spriešanu un to kopējais ticamības koeficients ir $\alpha=0,71$.

\section{Procedūra}

Pētijuma dalībnieki pētijumā piedalījās pēc brīvprātỉbas principa, un visi dalïbnieki tika informēti par to, ka viṇi spēlēs datorspēli ar vardarbības elementiem un ka ir iespēja atteikties no piedalīšanās eksperimentā jebkurā laikā.

Eksperiments notika LU PPMF datorklasē. Pirms eksperimenta sākuma dalībnieki aizpildīja Dusmu pašnovērtējuma anketu, kas deva iespēju noteikt viṇu agresijas 
stāvokli pirms spēlēšanas. Pēc tam sekoja ìsa instrukcija par datorspēles noteikumiem un mehāniku, visiem dalībniekiem tika parādīts, kā vajag spēlēt un ko vajag darìt. Pēc instrukcijas visi dalībnieki spēlēja 20 minūtes, ieņemot attiecīgo spēles lomu.

Pēc spēlēšanas dalībnieki atkārtoti aizpildīja Dusmu pašnovērtējuma anketu, kā arī pēc tam katrs dalībnieks aizpildīja Prosociālās spriešanas aptauju. Kopumā piedalīšanās pētỉjumā aizņēma 40-45 minūtes.

\section{Rezultāti}

Lai pārbaudītu pētījuma hipotēzes, tika veikta ievākto datu statistiskā analīze ar SPSS datu apstrādes programmas palīdzību. Izmantojot Kolmogorova-Smirnova testu, tika noteikta pētijuma datu empīiskā sadalījuma atbilstība normālajam sadalījumam. Empīriskais sadalijums neatbilda normālam sadalijumam, līdz ar to turpmākajos aprēķinos tika izmantotas neparametriskās secinošās statistikas metodes. Salīdzinot agresīvās izjūtas un prosociālas spriešanas rādītājus starp sievietēm un vīriešiem, netika konstatētas statistiski nozīmīgas atšķirības.

\section{Agresīvas izjūtas}

Lai atbildētu uz jautājumu, vai pastāv statistiski nozīmīga atšķirība agresīvās izjūtas rādītājos starp ložmetējnieku un mediķu grupām, tika izmatots Manna-Vitneja U kritērijs . Tika noskaidrots, ka starp grupām nepastāvēja atšķirīibas agresīvās izjūtas rādītājos pirms dalībnieki sāka spēlēt. Savukārt, statistiski nozīmīgas atškiriības dusmu rādītājos parādījās pēc spēlēšanās $(U=135,00, p<0,05)$; verbālās agresijas rādītājos $(U=147,00, p<0,05)$; un fiziskās agresijas rādītājos $(U=162,00, p<0,05)$. Visās skalās ložmetējnieku grupas agresijas rādītāji bija statistiski nozīmīgi augstāki par mediķu grupas rādītājiem (skat. 2. attēlu). Mediķu grupas $(M=5,57, S D=5,61, M e=4)$ kopējais agresijas stāvoklis bija ievērojami zemāks, nekā dalībniekiem no ložmetējnieku grupas $(M=11,91, S D=7,43, M e=10)$ (skat. 1. tabulu).

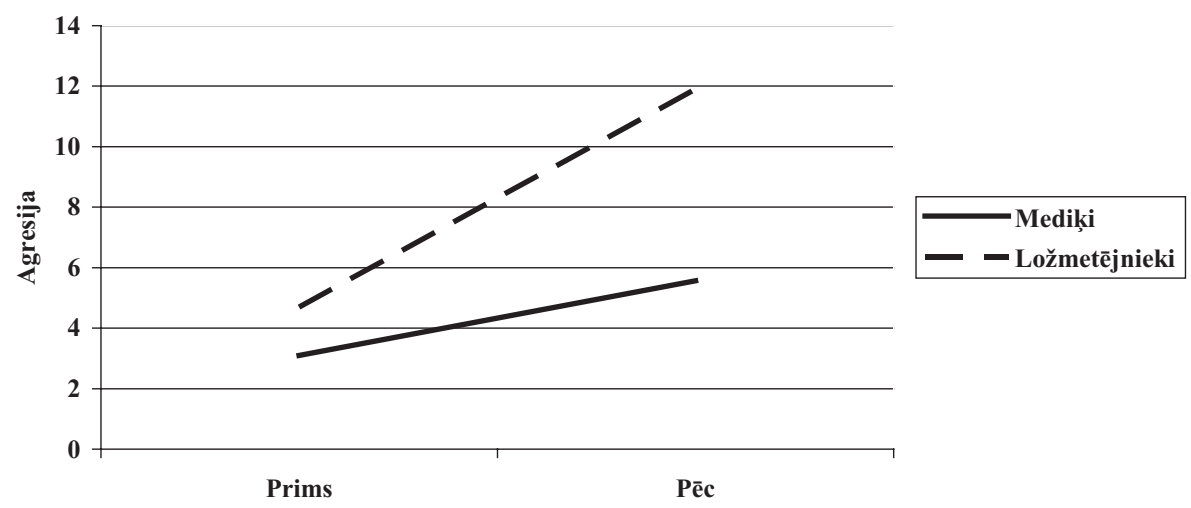

2. attēls. Mediķu un ložmetējnieku grupu agresīvo izjūtu rādītāji pirms un pēc spēlēšanas 
Datorspēlu prosociālas vai agresīvas lomas spēlēšanas ietekme uz jauniešu agresīvām izjūtām ..

1. tabula. Salīdzinājums starp mediķu un ložmetējnieku grupu agresīvo izjūtu rādītājiem pirms un pēc datorspēles spēlēšanas

\begin{tabular}{|c|c|c|c|c|c|c|c|}
\hline & \multicolumn{3}{|c|}{ Mediķi } & \multicolumn{4}{|c|}{ Ložmetējnieki } \\
\hline & $M$ & $S D$ & $M e$ & $M$ & $S D$ & $M e$ & U kritērijs \\
\hline \multicolumn{8}{|c|}{ Dusmas } \\
\hline Pirms & 1,22 & 1,858 & 1,00 & 1,61 & 2,482 & 1,00 & 247,000 \\
\hline Pēc & 2,00 & 2,412 & 1,00 & 4,26 & 3,033 & 4,00 & $135,000^{\star *}$ \\
\hline \multicolumn{8}{|c|}{ Verbāla agresija } \\
\hline Pirms & 0,87 & 1,290 &, 00 & 1,48 & 2,333 & ,00 & 238,000 \\
\hline Pèc & 1,91 & 2,275 & 2,00 & 4,22 & 3,133 & 3,00 & $147,000^{\star *}$ \\
\hline \multicolumn{8}{|c|}{ Fiziskā agresija } \\
\hline Pirms & 1,00 & 1,537 & 1,00 & 1,61 & 1,644 & 1,00 & 195,000 \\
\hline Pēc & 1,65 & 1,945 & 1,00 & 3,43 & 2,921 & 3,00 & $162,000^{*}$ \\
\hline \multicolumn{8}{|c|}{ Agresijas stāvoklis } \\
\hline Pirms & 3,09 & 3,765 & 2,00 & 4,70 & 5,138 & 2,00 & 231,500 \\
\hline Pēc & 5,57 & 5,607 & 4,00 & 11,91 & 7,434 & 10,00 & $115,000^{* *}$ \\
\hline
\end{tabular}

$p<0,05^{*}, p<0,01^{* *}$

Apkopojot iegūtus rezultātus, var izsecināt, ka pirmā hipotēze apstiprinājās jaunieši, kuri spēlēja vardarbīgo datorspēli, ieņemot prosociālu lomu, uzrādīja zemākas agresijas rādītājus nekā jaunieši, kuri spēlēja vardarbīgas datorspēles, ieṇemot agresīvu lomu.

\section{Prosociāla spriešana}

Lai pārbaudītu, vai starp abām grupām pastāv statistiski nozīmīga atškirīiba prosociālajos rādītājos pēc datorspēles spēlēšanas, tika izmantots Manna-Vitneja U kritērijs. 2. tabulā ir redzams, ka jaunieši, kuri spēlēja vardarbīgo datorspēli, ieṇemot prosociālo lomu (mediķu grupa) $(\mathrm{M}=7,48, \mathrm{SD}=1,163, \mathrm{Me}=8)$, uzrādīja augstākus prosociālas spriešanas rādītājus, nekā jaunieši no ložmetējnieku grupas $(M=6,70$, $\mathrm{SD}=1,2, \mathrm{Me}=7$ ) (skat 2. tabulu). Tas norāda, ka jaunieši no mediķu grupas bija vairāk gatavi palīdzēt, nekā jaunieši no ložmetējnieku grupas. Dalībnieki no mediķu grupas visās trīs aprakstītajās situācijās caurmērā vairāk izvēlējas palīdzošu uzvedību, salīdzinot ar ložmetējnieku grupu. Dalībnieki no ložmetējnieku grupas visās trīs situācijās visvairāk atzīmēja, ka viṇi nezina, ko vajag darīt. Starp grupām tika konstatēta statistiski nozīmīga atšķirība hedonistiskās spriešanas apakšskalā, dalībniekiem no mediķu grupas hedonistiskās spriešanas rādītāji bija zemāki tendenču līmenī $(p=0,051)$, salīdzinot ar ložmetējnieku grupu. Grupu rādītāju salīdzinājums rāda, ka starp grupām nebija statistiski nozīmīgo atšķirību sekojošās skalās: atzinību-orientēta spriešana, stereotipiskā spriešana, vajadzību-orientēta spriešana un internalizētā spriešana (skat. 2. tabulu). 
2. tabula. Salīdzinājums starp mediķu un ložmetējnieku grupu prosociālās spriešanas rādītājiem pēc datorspēles spēlēšanas

\begin{tabular}{lccccccc}
\hline & \multicolumn{4}{c}{ Mediki } & \multicolumn{5}{c}{ Ložmetējnieki } \\
\hline \multirow{2}{*}{ Hedonistiskā spriešana } & $M$ & $S D$ & $M e$ & $M$ & $S D$ & $M e$ & U kritērijs \\
\hline & 4,66 & 1,01 & 4,57 & 5,19 & 0,91 & 5,43 & $176,000^{\mathrm{t}}$ \\
\hline Stereotipiskā spriešana & 5,42 & 0,79 & 5,33 & 5,02 & 1,11 & 5,00 & 211,000 \\
\hline Vajadzību-orientēta spriešana & 5,01 & 1,22 & 5,33 & 5,13 & 0,98 & 5,00 & 258,500 \\
\hline Internalizētā spriešana & 5,08 & 0,69 & 5,33 & 5,18 & 0,81 & 5,33 & 243,000 \\
\hline Prosociālā spriešana & 7,48 & 1,16 & 8,00 & 6,70 & 1,22 & 7,00 & $167,000^{*}$ \\
\hline
\end{tabular}

$p<0,05^{*}$, t norāda uz atškirīibām tendenču līmenī $p=0,051$

\section{Diskusija}

Šì pētījuma mērḳis bija noskaidrot vai datorspēlu spēlētāju agresīvās izjūtas un prosociālo spriešanu ietekmēs tas, vai viņš/viņa ieņem prosociālu vai agresīvu lomu, spēlējot vardarbīgu datorspēli ar prosociāliem elementiem. Pētījuma rezultāti rāda, ka pēc datorspēlēšanas spēelētāji, kuri ien̦ēma prosociālo (mediķa) lomu, uzrādīja ievērojami mazāk agresīvu izjūtu, salīdzinot ar spēlētājiem, kuri ieṇēma agresīvo (ložmetējnieku) lomu. Kā arī pētỉjumā gaitā tika atklāts, ka pēc datorspēlēšanas spēlētāji ar prosociālu lomu uzrādīja augstākus prosociālās spriešanas rādītājus, nekā spēèteāji, kuri ieņēma agresīvo lomu.

Šì pētijuma rezultāti saskan ar citiem pētījumiem šajā sfērā (Gitter et al., 2013; Greitemeyer et al., 2011; Jerabeck \& Ferguson, 2013), kur tika atklāts, ka vardarbīgas datorspēles ar prosociāliem elementiem izraisa ievērojami mazāk agresijas un vairāk prosociālas spriešanas nekā vardarbīgas datorspēles bez šāda daudzpusīga stāstījuma. Tomēr šis pētijjums atšķiras no lïdzšinējiem, jo iepriekšējos pētījumos dalībnieki tika sadalīti grupās un katra grupa spēlēja atškirīgas spēles - vai nu viennozīmīgi ar vardarbỉbu vai ar vardarbību ar prosociāliem elementiem (piemēram, Star Wars), vai viennozīmīgi prosociālu spēli. Savukārt, šì pētījuma novitāte ir saistìta ar to, ka pētijjuma dalībnieki spēlēja vienu un to pašu spēli, bet ieņemot dažādas - agresīvas vai prosociālas - lomas. Tieši darbība šajās atškirīigās lomās ietekmēja prosociālo spriešanu un agresīvās izjūtas.

Iegūtos rezultātus var skaidrot saskaņā ar Andersona un Baklijas teorētisko Vispārējo iemācǐšanas modeli (Buckley \& Anderson, 2006). Teorētiski var postulēt, ka dalībniekiem, kuri spēlēja ložmetējnieku grupā, datorspēles vardarbīgais saturs un viṇu agresīvā loma kā ložmetējnieki, aktivizēja un aktualizēja viṇu kognitīvās shēmas un zināšanu struktūras, saistītas ar vardarbỉbu un agresiju, kas savukārt paaugstināja viṇu pašreizējās agresīvās izjūtas. Atšķirīga situācija bija novērojama otrajā - mediḳu 
grupā, kas spēlēja to pašu datorspēli, bet ar prosociālo lomu, un kur grupas dalībnieku pašreizējās agresīvo izjūtu līmenis bija divas reizes mazākas, salīdzinot ar pirmo grupu. Tas liek domāt, ka datorspẹlı spēlētājiem pieškirtā loma bija ar ìpašu nozìmi, jo tā veicināja vai nu agresīvo vai prosociālo kognīiiju un emociju aktivizēěanos. Datorspēlu spēlētājiem, kuri ieṇēma agresīvo lomu, agresīvā darbība spēles gaitā aktivizēja viṇu agresīvās kognitīvās shēmas un negatīvās emocijas. Savukārt, datorspēẹu spēlētāiiem, kuri ieņēma prosociālo mediķa lomu, prosociālā darbība spēles gaitā aktivizēja vinuu prosociālās kognitīvās shēmas un uz palīdzēšanu vērstās emocijas. Dalībniekiem no mediķu grupas bija arī zemāki hedonistiskās spriešanas rādītāji, nekā dalībniekiem no ložmetējnieku grupas, kas liek domāt, ka spēlētāju prosociālā darbība aktivizēja prosociālas zināšanas struktūras, un līdz ar to dalībniekiem no mediḳu grupas bija tendence vairāk rūpēties par citiem, nevis domāt hedonistiski, kad viniem bija lūgts palīdzēt vai nepalīdzēt stāstu varonim prosociālās spriešanas aptaujā.

Pētỉjumam ir vairāki ierobežojumi. Pirmkārt, dalībnieki spēlēja kopā vienā telpā, un, neskatoties uz to, ka viṇi tika informēti, ka viṇi spēlē atseviški no visiem pārējiem dalībniekiem, tās varēja ietekmēt viṇa spēles iesaistîšanās līmeni. Otrkārt, metode prosociālās spriešanas novērtěšanai pētījumā Latvijā tika izmantota pirmo reizi, un to vajadzētu vēl papildus pārskatīt un, iespējams, koregeèt, lai uzlabotu ticamības rādītājus. Treškārt, respondentu izlase bija diezgan neliela- 46 cilvēki. Treškārt, prosociālā spriešana tika mērīta tikai pēc spēlēšanas, un nav informācijas, vai tā starp grupām neatšķ̄īās jau sākotnēji. Ir nepieciešami turpmāki pētỉjumi ar lielāku izlasi, lai atkārtoti pārbaudītu iegūtos rezultātus un, lai būtu iespējas rezultātus vispārināt uz jauniešu populāciju. Jāṇem vērā arī tas, ka pētijuma realizācijai bija tehniskās nepilnības - visi dalībnieki spēēēja bez datorspēles audiālā komponenta un iespējams, ka gan prosociālie, gan agresijas rādītāji būtu augstāki, ja dalībnieki spēēētu ar audiālo komponentu.

Nākotnē būtu interesanti un vērtīgi izpètīt šos jautājumus longitudinālā pētỉjumā, lai noskaidrotu, vai pozitīvā ietekme uz prosociālo domāšanu saglabāsies, vai palielināsies ilgtermin̄ā. Svarīgi ir pētìt tieši jaunās datorspēles ar komplicētu struktūru, tādas spēles, kur prosociālie elementi nav tik acīmredzami, kā arī, kur vardarbība nav spēles galvenais fokuss, jo senāk izstrādātās datorspēles, kas ir tikušas izmantotas daudzos psiholog̣iskajos pētijumos, vairs nereprezentē datorspēlētāju populāciju. Prosocālie elementi var parādīties ne vien spēles mehānikā, bet arī spēles saturā (piem., Mass Effect, Dragon Age: Origins, Hitman: Absolution), un ir vērts pārbaudìt, kā vardarbīgas datorspēles ar prosociāliem elementiem spēles saturā ietekmēs spēlētāju prosociālo domāšanu. Kā arī ir svarīgi izpètìt datorspēles, kur spēlētājs pats pieņem lēmumus, kā viņam(ai) rīkoties noteiktā situācijā - izmantojot spēku vai izmantojot diplomātiju (piem., Deus Ex: Human Revolution, Fallout: New Vegas, Dishonored). Jo tādas datorspēles kḷūst arvien populārākas ar katru gadu, un tām ir ḷoti plaša auditorija.

Iegūtos rezultāti varētu izmantot, lai ierosinātu datorspēḷ dizainerus iekḷaut savās datorspēlēs arvien vairāk prosociālus elementus, lai samazinātu negatīvo ietekmi uz agresiju. Kā arī rezultātus varētu izmantot, lai samazinātu viennozīmīgo viedokli saistībā ar datorspēḷu negatīviem efektiem uz spēlētājiem, jo, balstoties uz iegūtiem rezultātiem, pat vardarbīgām datorspēlēm var būt pozitīva ietekme, ja spēle dod iespēju spēelētājam iesaistīties prosociālā darbībā. 


\section{Izmantotā literatūra}

Adachi, P. J., \& Willoughby, T. (2013). More than just fun and games: The longitudinal relationships between strategic video games, self-reported problem solving skills, and academic grades. Journal of Youth and Adolescence, 42, 1041-1052.

Anderson, C. A. (2004). An update on the effects of playing violent video games. Journal of Adolescence, 27, 113-122.

Anderson, C. A. (2016). Media violence effects on children, adolescents and young adults. Health Progress, July, 59-62.

Anderson, C. A., Ihori N., Bushman, B. J., Rothstein, H. R., Shibuya, A., Swing, E. L., Sakamoto, A., \& Saleem, M. (2010). Violent video game effects on aggression, empathy, and prosocial behavior in eastern and western countries: a meta-analytic review. Psychological Bulletin, 136, 151-173.

Bandura, A., (1971). Social learning of moral judgments. Journal of Personality \& Social Psychology, 11, 275-279.

Bremane, I. (2005). Spīlbergera dusmu testa (State-Trait Anger Expression Inventory) 2. adaptācija un daḷēja standartizācija. Nepublicēts maǵistra darbs, LU, PPF psihologiijas nodal̦a, Rìga.

Buckley, K. E., \& Anderson, C. A. (2006). A theoretical model of the effects and consequences of playing video games. Playing Video Games - Motives, Responses, and Consequences, 24, 363-378.

DeWall, N. C., Anderson, C. A., \& Bushman B. J. (2011). The general aggression model: theoretical extensions to violence. Psychology of Violence, 1, 245-258.

Entertainment software association (2014). Essential facts about the computer and video game industry. Retrieved June 10, 2015, from http://www.theesa.com/wpcontent/uploads/2014/10/ ESA_EF_2014.pdf

Entertainment software association (2015). Essential facts about the computer and video game industry. Retrieved January 17, 2016, from http://www.theesa.com/wp-content/ uploads/2015/04/ESA-Essential-Facts-2015.pdf.

Gentile, D. (2009). Pathological video-game use among youth ages 8 to 18. Psychological Science, 20 (5), 594-603.

Gitter, S. A., Ewell, P. J., Guadagno, R. E., Stillman, T. F., \& Baumeister R. F. (2013). Virtually justifiable homicide: the effects of prosocial contexts on the link between violent video games, aggression, and prosocial and hostile cognition. Aggressive Behavior, 39, 346-354.

Granic, I., Lobel A., \& Engels, R. C. M. E. (2014). The benefits of playing video games. American Psychologist, 69 (1), 66-78.

Green, C. S., \& Bavelier, D. (2012). Learning, attentional control, and action video games. Current Biology, 22, 197-206.

Greitemeyer, T., Agthe, M., Turner, R., \& Gschwendtner, C. (2011). Acting prosocially reduces retaliation: effects of prosocial video games on aggressive behavior. European Journal of Social Psychology, 42, 235-242.

Gustavo, C., Eisenberg, N., \& Knight, G. P. (1992). An objective measure of adolescents' prosocial moral reasoning. Journal of Research on Adolescence, 2(4), 331-349.

Jerabeck, J. M., \& Ferguson, C. J. (2013). The influence of solitary and cooperative violent video game play on aggressive and prosocial behavior. Computers in Human Behavior, 29, 2573-2578. 
Saleem, M., Anderson, C. A., \& Gentile, D. A. (2012). Effects of prosocial, neutral, and violent video games on children's helpful and hurtful behaviors. Aggressive Behavior, 38, 281-287.

Sebre, S., Bite, I., Miltuze, A. (2011). Pozitīvi un negatīvi aspekti no pusaudžu un jauniešu interneta lietošanas paradumiem: kvantitatīva un kvalitatīva analīze. Apvienotais Pasaules latviešu zinātnieku III kongress un Letonikas IV kongress "Zinātne, sabiedrība un nacionālā identitāte" Rīgā, 24.-27. oktobrī.

Spielberger, C. D., Sydenman, S. J., Owen, A. E., \& Marsh, B. J. (1999). Measuing Anxiety and Anger with the State-Trait Anxiety (STAI) and Sate-Trait Anger Expression Inventory (STAXI). In M. E. Maruish (Ed.), The use of Psychological testing for Treatment Planning and Outcomes Assessment (pp. 993-1017). Mahwah: Lawrence Erlbaum Associates.

Wallenius, M., Punamaki, R. L., \& Rimpela, A. (2007). Digital game playing and direct and indirect aggression in early adolescence: the roles of age, social intelligence, and parent-child communication. Journal of Youth and Adolescence, 36, 325-336. 


\title{
Skolotāju skaidrojumi par skolēnu problemātiskās uzvedības motīviem un par savām reakcijām uz skolēnu problemātisko uzvedỉbu
}

\author{
Signe Knipše un Baiba Martinsone ${ }^{1}$ \\ Latvijas Universitāte
}

\begin{abstract}
Abstrakts
Kvalitatīvi kvantitatīvajā pētījumā, izmantojot trīs iedomātu situāciju aprakstus, tika veiktas strukturētas sarunas ar skolotājiem par skolēnu problemātiskas uzvedības motīviem un skolotāju reakciju uz tiem. Pētijumā piedalījās 20 sākumskolas un pamatskolas skolotājas (vidējais vecums 43 gadi, vidējais pedagogiskā darba stāžs 17 gadi). Strukturēto sarunu teksti tika analizēti pēc tematiskās analīzes principiem. Pētījums apstiprina, ka pastāv saistība starp uzvedības motīva skaidrojumu un skolotāja uzvedības reakciju. Negatīiāks motīva skaidrojums izraisa negatīvāku atbildes reakciju, un otrādi: ja skolotājas skolēna uzvedības motīvu novērtē kā pozitīvu, tad atbildes reakcija ir mazāk negatīva. Skolotājas skolēnu uzvedību biežāk skaidro ar situatīviem iemesliem, trīs reizes retāk ar dispozicionāliem iemesliem. Skolēnu uzvedības motīvu skaidrojumā skolotājas mazu lomu pievērš ārējiem apstākḷiem. Skolas vides, mācību procesa ietekme skolotāju skaidrojumos gandrīz netiek pieminēta. Pētāmajā grupā skolotājām, saskaroties ar skolēnu problemātisku uzvedību, ir grūtības saprast savas emocijas.
\end{abstract}

Atslēgas vārdi: skolēnu problemātiska uzvedība, skolotāja skaidrojums par skolēna rīcības motīviem, skolotāja uzvedības reakcija, skolotāja emocionālā reakcija, atribūcijas.

\section{Teacher's Atributions of Student Misbehavior and Responses to it Signe Knipše and Baiba Martinsone \\ University of Latvia}

\begin{abstract}
This was a qualitative-quantitative study in which descriptions of three typical school-based situations were used as a basis for structured interviews with teachers in order to determine their perceptions about the causes of students' misbehaviour, and how they predict their behavioural and emotional reactions to this misbehaviour. Twenty primary and middle school teachers participated in the study (average age 43 years old, average work experience 17 years). The interviews were analysed according to the principles of thematic analysis. Results of the analysis confirmed the link between the teacher's attribution of behaviour motive and reaction to the behavior. More negative attributions of misbehaviour were linked with a more negative response, and vice versa, if the teacher's perceptions about the cause of misbehaviour were more
\end{abstract}

Corresponding author: Maiba Martinsone, University of Latvia, Jurmalas gatve 76, Riga LV-1083, Latvia.

Email: baiba.martinsone@lu.lv 
positive, then predicted reactions also were more positive. Teachers most often explained student misbehaviour with situational factors, much less so with dispositional factors. The impact of other factors such as school environment or curriculum were mentioned rarely. The study also indicated that the teachers have difficulties in understanding their emotions which arise as a result of the problematic behaviour of students.

Keywords: student problematic behavior, teachers' perceptions of student motives, teachers' behavioral and emotional reactions, attributions.

Bērnu un pusaudžu uzvedības problēmas tiek definētas kā vecumam vai situācijai neatbilstoša uzvedība un neapmierinātības izrādīšana sociāli nepieṇemamā formā, kas apgrūtina mijiedarbību skolā un gimenē. Tomēr līdztekus tiek norādīts, ka šādas uzvedības problēmas kādā konkrētā bieži vien ar stresu saistītā situācijā vai noteiktā attīstības vecumposmā - īpaši pusaudžu vecumā - izrāda daudzi bērni un pusaudži (Kauffman, 2005; Kazdin, 2000; Achenbach \& Rescorla, 2001; kā minēts Pirsko, 2010). Ikdienā skolotājiem nākas saskarties ar plašu skolēnu uzvedības spektru, tostarp tādu uzvedību, kas neatbilst skolas kārtības noteikumiem un sabiedrībā pieṇemtajām normām. Šajā darbā problemātiskā uzvedība tiek skatīta kā skolas noteikumu pārkāpumi, neizdalot smagus uzvedības un emocionālos traucējumus.

Viens no teorētiskajiem ietvariem, kas tiek izmantots, lai aprakstītu, kā skolotāji uztver un skaidro skolēnu problemātiskas uzvedības iemeslus, ir atribūcijas teorija (Jones \& Davis, 1966; Kelley, 1967; Weiner, 1974, kā minēts Reņgé, 2002). Novērtējot kāda cita rīcību, visbiežāk negatīvi iekrāsotu, cilvēkiem ir tieksme nenovērtēt situatīvo faktoru nozīmi un pārvērtēt personisko faktoru nozīmi cilvēka uzvedības cēlonībā (Wickens et al., 2011). Starp nozīmīgākajiem atribūcijas teorijas veidotājiem, kas ir pievērsies šis teorijas pieñēmumu pētījumiem izglìtības jomā, ir minams Bernards Veiners (Bernard Weiner). Saskaņā ar Veinera izstrādāto modeli tas, kā cilvēki skaidro uzvedības cēloṇus, ir saistīts ar šādiem aspektiem: 1) lokusu - vai tiek uzskatīts, ka uzvedības iemesls ir iekšējs vai ārējs attiecīgajai personai; 2) stabilitāti - vai uzvedība tiek skaidrota kā vienmēr raksturīga ir attiecīgajam cilvēkam un 3) kontrolējamību - vai cilvēks varēja ietekmēt savu uzvedību (Reyna \& Weiner, 2001; Weiner, 2003). Pētïjumi apliecina, ka skolotājiem ir tendence skaidrot problēmas klasē ar skolēnu rakstura īpašìbām un iezīmēm (within-student characteristics) - tātad lokuss ir ārpus skolotāja tiešas ietekmes (Medway, 1997; Anthanasiou et al., 2002). Attiecībā uz stabilitātes dimensijas lomu atribūcijas procesā skolā vairāki pētījumi parāda: ja skolotāji skolēna grūtības skaidro ar stabilām personiskām īpašībām, piemēram, uzskatot, ka skolēns ir sliṇkis, viņi paredz, ka skolēnam attiecīgajā priekšmetā arī nākotnē būs vāji mācību rezultāti (Gibss \& Gardiner, 2008; Dobbs \& Arnold, 2009). Kopumā pētījumi apliecina, ka skolotājiem ir tendence problemātiskas uzvedības un mācību grūtību cēloṇus biežāk piedēvēt skolniekiem, nevis saviem mācīšanas vai audzināšanas paṇēmieniem un attieksmei (Medway, 1979). Tomēr ir arī pētijumi, kas rāda, ka, novērtējot skolēnu uzvedības cēlonību, skolotāji izprot konteksta, situācijas un savas ietekmes nozīmi (Gibss \& Gardiner, 2008). 
Tas, kā skolotāji skaidro skolēnu problemātiskas uzvedības cēloṇus, būtiski ietekmē arī pašu skolotāju rīcību un izjūtas. Ja skolotājs skaidro skolēna uzvedību ar stabilām skolēna iezīmēm, piemēram, rakstura īpašībām, pārliecībām, motīviem, tad skolotājam ir tendence izjust dusmas, savukārt rīcība ir vērsta uz sodu. Un pretēji, ja uzvedība tiek skaidrota ar situatīviem, nekotrolējamiem un nepastāvīgiem iemesliem, tad skolotājs izjūt žēlumu, un viņa rīcība drīzāk būs vērsta uz atbalstu un palīdzību (Reyna \& Weiner, 2001; Bibou-Nakouetal., 2000; Alvarez, 2007).

Cēlonības skaidrojums ietekmē pedagoǵisko procesu kopumā. Ja problemātiskās uzvedības cēloṇi tiek piedēvēti skolēnam - tie tiek saistīti ar personību, tie tiek uzskatīti par stabiliem un skolēnam kontrolējamiem, - tad skolotājs var uzskatīt, ka problēma ir jārisina skolēnam (Aldrich \& Martens, 1993; Reyna \& Weiner, 2001; Riley et al., 2010).

Var secināt, ka skolēnu problemātiskā uzvedība un tās cēlonības uztvere ir būtisks faktors, kas ietekmē skolotāju un skolēnu ikdienu un arī attiecības nākotnē.

Pētījumam tika izvirzīti divi jautājumi:

1) kāds ir skolotāju skaidrojums par skolēnu problemātiskas uzvedības motīviem;

2) kāda saistība pastāv starp skolotāju uztverto skolēna uzvedības motīvu un to, kā skolotāji skaidro savu iespējamo uzvedības reakciju?

\section{Metode}

\section{Pētijuma dalībnieki}

Pētījumā piedalījās 20 sākumskolas un pamatskolas skolotājas vecumā no 25 līdz 61 gadiem, vidējais vecums 43 gadi. Pētījuma dalībnieču pedagoǵiskā darba stāžs variē no 1 līdz 41 gadam (vidējais stāžs 17 gadi). Visām skolotājām ir augstākā pedagoǵiskā izglìtỉba, $85 \%$ ir sākumskolas vai pamatskolas skolotāja izglìīiba, 15\% - cita specialitāte. 18 respondentes (90\%) ir kādas klases audzinātājas, no tām 16 (80\%) audzina 1.-4. klasi, 2 (10\%) - 5. un 6. klasi. Divas respondentes (10\%) skolā strādā par priekšmetu skolotājām.

\section{Instrumentārijs}

Pētījumos par uzvedības cēlonības skaidrojumu bieži tiek izmantotas vinjetes, tās sauc arī par situāciju aprakstiem, kurus izlasot vai noskatoties, respondentiem lūdz atbildēt uz jautājumiem. Reizēm šādi pētījumi tiek veikti rakstiskā formā, izmantojot aptaujas, taču šajā pētījumā tās bija intervijas klātienē. Balstoties uz dažādu autoru pētījumos izmantoto instrumentāriju aprakstiem (piem., Snyder et al., 2005; Alvarez et al., 2007; Wickens et al., 2011), šì darba nolūkam tika izveidoti trīs apraksti situācijām tā, lai tās attēlotu skolas vidē ikdienišḳu problēmuzvedību, lai tās ietvertu problemātisku uzvedību gan mācību procesā, gan ārpus tā, lai situāciju aprakstos būtu iekḷauti dažāda dzimuma skolēni, kā arī, lai skolotāju loma aprakstītajās situācijās būtu atšķirīga. Visi 
sižeti tika veidoti tā, lai skolēnu uzvedības motīvi tajos būtu neskaidri. Pētījumā tika izmantoti šādi situāciju apraksti:

1. Iepriekšèjā stundā pirms nozīmīgas ieskaites jūs veicat strukturētu vielas atkārtojumu. Kāds skolēns, solā sēžot, knibinās ar rakstāmlietām, pakrāmējas pa somu, pēc tam piecel̦as un bez paskaidrojumiem iziet no klases.

2. Jūs esat aculieciniece šādai situācijai. Starpbrīdī meitene uz austiṇām klausās mūziku. Pienāk zēns un aizrāda, ka skolā tas nav atḷauts. Meitene nepievērš viṇam uzmanību, bet zēns izrauj austiņas, un dodas prom. Meitene stipri iesper zēnam.

3. Klasē uz grīdas izbiruši papīri. Jūs lūdzat klases dežurantiem izbirušo savākt. Meitene atbild, ka klase pirms tam bija jau iztīrīta, viṇa to neizbēra un viṇai nav laika. Zēns cieši skatās uz jums un klusē.

Pēc katra apraksta skolotājiem tika lūgts atbildēt uz jautājumiem par katra no situācijā pieminētā skolēna rīcības iemesliem (Kā jūs domājat, kāpēc skolēns tā rīkojās?) par to, ko skolotājs šādā situācijā darītu (Kā jūs reaǵētu šajā situācijā? Ko tieši jūs darìtu?) un, kā skolotājs justos (Kā jūs justos šajā situācijāe), kā arī tika lūgts aizpildìt demogrāfisko aptauju.

\section{Procedūra}

Izveidotie situāciju apraksti tika pārbaudīti pilotāžas pētījumā. Iegūtie rezultāti apliecināja, ka situācijas ir izvēlētas atbilstoši tām problemātiskas uzvedības situācijām, ar ko ikdienā saskaras sākumskolas un pamatskolas skolotājas. Vairums pētījuma dalībnieces atzina, ka "šādas situācijas gadās”, ka "tā bieži notiek”.

Dalība šajā pētījumā bija brīvprātīga un ar skolotājām, kas piekrita piedalīties, notika individuālas tikšanās. Visas intervijas, izņemot vienu, notika attiecīgo skolotāju darba vietās, viena intervija notika skype. Pirms intervijas respondentes tika īsi iepazīstinātas ar pētījuma tēmu, tika pārrunāti anonimitātes jautājumi. Vidēji intervijas ilga 20 minūtes, tā tika ierakstīta diktofonā.

Pēc interviju atšifrēšanas tika veikta iegūtā materiāla kvalitatīva analīze par katra sižeta pēc situāciju nolasīšanas uzdotajam jautājumam - par katra skolēna rīcības motīviem, par skolotāja pašprognozēto rīcību un par pašprognozētajām izjūtām. Katras intervijas transkripts tika lasīts vairākas reizes, lai iegūtu priekšstatu par kopējo atbilžu noskaṇu. Atbilstoši tematiskās analīzes principiem no katras atbildes tika izdalītas satura vienības. Atsevišķās satura vienības tika apkopotas vadošajās tēmās, no kurām noslēgumā tika izveidotas kategorijas. Analīzes noslēgumā izveidotās kategorijas tika salīdzinātas ar atribūcijas teorijas principiem, galvenokārt Veinera atziṇām par uzvedības motīvu dimensijām un reakcijas dimensijām.

\section{Rezultāti}

No skolotāju skaidrojumiem par skolēnu rīcības motīviem visās trīs situācijas tika izveidotas sešas kategorijas (skat. 1. tabulu). 


\section{1. tabula. Skolotāju skaidrojumu par skolēnu rīcības motīviem kategorijas, tēmas un atbilžu piemēri}

\begin{tabular}{|c|c|c|}
\hline Kategorijas & Tèmas & Piemēri \\
\hline \multirow[t]{3}{*}{$\begin{array}{l}\text { Negatīvas personības } \\
\text { dispozīcijas }\end{array}$} & Negatīvas personības iezīmes & $\begin{array}{l}\text { "Vinnš ir iedomīgs", "agresīva meitene", piemē- } \\
\text { ram, "viņš tāds l̦oti pareizs" [pārnestā nozīmē]. }\end{array}$ \\
\hline & $\begin{array}{l}\text { Negatīva attieksme pret } \\
\text { mācībām, skolu, skolotāju }\end{array}$ & "Demonstratīvi parāda attieksmi pret skolu". \\
\hline & Mācišanās grūtības & $\begin{array}{l}\text { "Uzmanības problēmas", "ḷti daudz ko } \\
\text { nesaprot". }\end{array}$ \\
\hline \multirow[t]{2}{*}{$\begin{array}{l}\text { Pozitīvas un neitrālas } \\
\text { personības dispozīcijas }\end{array}$} & $\begin{array}{l}\text { Pozitīvas personības iezīmes, } \\
\text { uzvedības paradumi, attieksmes }\end{array}$ & $\begin{array}{l}\text { "Varbūt viña ir cilvēks, kas visu laiku uztur } \\
\text { kārtību cilvēks visu laiku uztur kārtību". }\end{array}$ \\
\hline & Zēns netic saviem spēkiem & $\begin{array}{l}\text { "Zēns ir zaudētāja lomā," viṇš nejūtas par sevi } \\
\text { pārliecināts". }\end{array}$ \\
\hline $\begin{array}{l}\text { Ar attiecībām ar vien- } \\
\text { audžiem saistīti motīvi }\end{array}$ & $\begin{array}{l}\text { Attiecības starp zēnu un } \\
\text { meiteni }\end{array}$ & $\begin{array}{l}\text { "Nepatika pret meiteni", "simpātijas pret } \\
\text { meiteni". }\end{array}$ \\
\hline \multirow[t]{3}{*}{ Negatīvi ārējie apstākḷi } & Ar veselïbu saistīti iemesli & $\begin{array}{l}\text { "Laikam tam bērnam ir kādi traucējumi } \\
\text { [veselības]". }\end{array}$ \\
\hline & Problēmas ǵimenē & "Ģimenē kaut kas nav kārtībā". \\
\hline & Neskaidri klases noteikumi & $\begin{array}{l}\text { "Klasē līdz galam izrunāti dežuranta } \\
\text { pienākumi un pārējo atbildība". }\end{array}$ \\
\hline \multirow[t]{6}{*}{ Situatīvi negatīvi motīvi } & Zēns klusē, jo ir vainīgs & "Iespējams, ka zēns ir vainīgs". \\
\hline & $\begin{array}{l}\text { Meitene uzskata, ka drīkst tā } \\
\text { rîkoties }\end{array}$ & "Nejūtas vainīga, ka viṇa ir pārkāpēja". \\
\hline & Zēna negatīvās rīcíbas dēḷ & “Zēns viṇu pirmais izprovocēja”. \\
\hline & Nav gatavs stundā strādāt & "Varbūt viņu tas vienkārši neinteresê". \\
\hline & Dusmīgs uz skolotāju & "Īzjūt negatīvas emocijas pret skolotāju". \\
\hline & Meitene negrib vākt & $\begin{array}{l}\text { "Viņai tieši šajā dienā loti negribas pildìt šos } \\
\text { pienākumus". }\end{array}$ \\
\hline \multirow[t]{9}{*}{ Situatīvi neitrāli motīvi } & $\begin{array}{l}\text { Zēns izjūt netaisnību un at- } \\
\text { riebjas }\end{array}$ & $\begin{array}{l}\text { "Viņam ir aizkaitinājums, kāpēc viņa var } \\
\text { aţ̦auties tā darît". }\end{array}$ \\
\hline & Zēns cenšas uzturēt kārtību & $\begin{array}{l}\text { "Viņš ir stāva vai klases dežurants un viņam ir } \\
\text { jāuztur noteikumi". }\end{array}$ \\
\hline & Ar pašsajūtu saistiti iemesli & "Varbūt slikti palika”., " meitene ir nogurusi”. \\
\hline & Zēns nogaida & "Zēns skatās, kāda būs mana reakcija uz to visu". \\
\hline & $\begin{array}{l}\text { Meitene darbu jau bija pavei- } \\
\text { kusi }\end{array}$ & $\begin{array}{l}\text { "Meitenei škiet, ka viņa jau ir izdarījusi savu } \\
\text { pienākumu”, "varbūt viņai apnika”. }\end{array}$ \\
\hline & $\begin{array}{l}\text { Meitene aizsargāja sevi un } \\
\text { personīgo īpašumu }\end{array}$ & "Tāpēc, ka aiztika viņas personīgo īpašumu". \\
\hline & $\begin{array}{l}\text { Kaut kas personīgi svarīgs } \\
\text { atgadījās }\end{array}$ & "Kaut kas personīgi svarīgs atgadījās". \\
\hline & Kaut ko bija aizmirsis & "Varbūt kaut ko aizmirsis skapītī". \\
\hline & Stundas vielu zina & "Šḳita, ka viņš visu jau zina”." \\
\hline
\end{tabular}

Apvienojot skolotāju uztverto skolēna uzvedības motīvu tēmas, tika izveidotas šādas kategorijas:

Situatìvi neitrāli iemesli - apvieno tēmas, kurās skolotāji runā par laikā nestabiliem, ar situāciju saistītiem motīviem, skolotājiem ir emocionāli neitrāla attieksme, piemēram, "viņš kaut ko meklë", "viṇš nogaida”. 
Situatīvi negatīvi iemesli - skolotājs skolēna uzvedību skaidro ar motīviem, kas ir īslaicīgi, kurus skolēns var kontrolēt, piemēram, "meitenei ir slinkums [vākt papīrus], "grib pievērst citu skolēnu uzmanību". Skolotājai ir negatīva attieksme pret motīvu.

Pozitìvas un neitrālas personības dispozīcijas - skolotāji skaidrojumā min stabilas pozitīvas skolēna personības iezīmes, piemēram, "viṇa ir kārtīga meitene”, stabilus uzvedības paradumu, piemēram, "viṇa nekad nenomet”, kā arī skolēnu zemu pašvērtējumu - iezīmi, kas skolotājos raisa līdzjūtību.

Negatīvas personības dispozīcijas - skolotāji skaidrojumā min stabilus ar skolēna personību saistītus iemeslus - negatīvas skolēnu rakstura iezīmes, piemēram, "vinšs ir iedomīgs", "agresīva meitene”, dažkārt min pozitīvas īpašības pārnestā nozīmē, piemēram, "viņš tāds l̦oti pareizs", nepareizas audzināšanas sekas, piemēram, "tas jau slēpjas mājās", stabilus negatīvus paradumus, piemēram, "viṇš vienmēr nomet", negatīvu attieksmi, piemēram, "nepatika pret priekšmetu”. Skolotāji, raksturojot motīvu, nereti lieto apstākḷa vārdus "noteikti”, "vienmēr".

Negatīvi ārējie apstākḷi - skolotāji runā par laikā stabiliem, skolēnam nekontrolējamiem iemesliem,

Ar vienaudžu attiecībām saistīti motīvi - skolotāja motīvu skaidro ar pozitīvām un negatīvām attiecībām starp zēnu un meiteni, piemēram, "nepatika pret meiteni", "simpātijas pret meiteni".

No satura vienībām, kas tika izdalītas, analizējot skolotāju pašprognozēto uzvedības reakciju visās trīs situācijas, tika izveidotas četras kategorijas (skat. 2. tabulu).

\section{2. tabula. Skolotāju skaidrojumu par savu iespējamo reakciju kategorijas, tēmas un atbilžu piemēri}

\begin{tabular}{|c|c|c|}
\hline Kategorijas & Tèmas & Piemēri \\
\hline \multirow[t]{2}{*}{ Aktīva negatīva } & $\begin{array}{l}\text { Aizrādītu [abiem], [zēnam], } \\
\text { [meitenei] }\end{array}$ & $\begin{array}{l}\text { "Aizrādìtu vainīgajam", " būtu uz pārrunām gan puisis, } \\
\text { gan meitene, aizrādìtu abiem”. }\end{array}$ \\
\hline & Nosodìtu visu klasi & "Nel̦autu klasei iet, pirms nav salasīti papīri”. \\
\hline \multirow[t]{7}{*}{ Aktīva neitrāla } & $\begin{array}{l}\text { Aktīvi rìkotos, lai skolēns } \\
\text { paliktu vai atgrieztos klasēē }\end{array}$ & $\begin{array}{l}\text { "Noteikti ietu pakal,", "pievērstu uzmanību ar } \\
\text { jautājumu par stundas vielu”. }\end{array}$ \\
\hline & $\begin{array}{l}\text { Argumentētu un uzturētu } \\
\text { prasības }\end{array}$ & $\begin{array}{l}\text { "Izskaidrotu, atgādinātu dežurantu pienākumus, pastā- } \\
\text { vētu uz to, ka ir jāsavāc"', neḷautu ņemt līdzi austiņas". }\end{array}$ \\
\hline & Censtos situāciju izlīdzināt & Skolotāja stāsta, ka pieliktu pūles, lai konfliktu mazinātu \\
\hline & Noskaidrotu, kas nometa & "Noskaidrotu, vai viṇi redzēja, kas to izdarīja". \\
\hline & Noskaidrotu rīcības iemeslus & "Parunātu, kas ar viņu notika". \\
\hline & Pārrunātu situāciju ar visu klasi & "Klasē pēc tam pārrunātu to situāciju". \\
\hline & $\begin{array}{l}\text { Runātu par notikušo ar abiem } \\
\text { skolēniem }\end{array}$ & "Abus pasauktu un parunātu". \\
\hline \multirow[t]{4}{*}{ Atbalstoša } & Iesaistītos klases sakopšanā & "Ierosinu, varbūt, ka mēs varam kopīgi savākt". \\
\hline & $\begin{array}{l}\text { Mudinātu uz citu rīcības } \\
\text { stratégiju }\end{array}$ & $\begin{array}{l}\text { "Puisim citreiz ieteiktu vērsties pie pieaugušā", "neva- } \\
\text { jag izaicināt vīriešus". }\end{array}$ \\
\hline & Mēǵinātu palīdzēt mācībās & "Pastāvēšu klāt, līdz viņš to darbu uzsāks". \\
\hline & $\begin{array}{l}\text { Palīdzētu puisim un meitenei } \\
\text { vienoties }\end{array}$ & "Saku, ka mums viens otram jāpalīdz". \\
\hline Pasīva & Nepievērstu uzmanību & "Kad viņš izietu, nepievērstu uzmanību". \\
\hline
\end{tabular}


Apvienojot skolotāju pašprognozētās reakcijas tēmas, tika izveidotas šādas reakciju kategorijas: Aktīva neitrāla reakcija - skolotāji runā par aktīvu, bet emocionāli neitrālu rīcību. Aprakstot rīcību, lieto vārdus "noskaidrotu”, "pārrunātu”, "ietu pakalı"; Aktīva negatīva reakcija - skolotāja runā par to, ka "aizrādītu” skolēniem, ka aktīvi rīkotos, lai kaut ko aizliegtu; Atbalstoša reakcija - skolotāji min darbības, kas vērstas uz emocionālu un instrumentālu atbalstu skolēniem; Pasīva reakcija - skolotāji runā, ka situācijā nepievērstu uzmanību, vai censtos izvairīties.

Skolotāju pašprognozētajām izjūtām visās trīs situācijas tika izveidotas piecas kategorijas (skat. 3. tabulu).

\section{3. tabula. Skolotāju skaidrojumu par iespējamajām izjūtām kategorijas, tēmas un atbilžu piemēri}

\begin{tabular}{|c|c|c|}
\hline Kategorijas & Tèmas & Piemēri \\
\hline \multirow[t]{3}{*}{ Negatīvas izjūtas } & Izmisums & $\begin{array}{l}\text { "Izmisums, ja to dara bērns, kas pirmo reizi [iziet no } \\
\text { klases stundas laikā], "justos slikti”. }\end{array}$ \\
\hline & Dusmas & "Justos nikna", "kas atkal?" \\
\hline & Vilšanās & “Kāpēc tu nespēj sevi savaldīt, savākt" \\
\hline \multirow[t]{3}{*}{ Nevar pateikt, ko justu } & Nezina, kā justos & "Nezinu, kādas būtu izjūtas". \\
\hline & Noliedz emocijas & "Nekādu emociju nebūtu". \\
\hline & $\begin{array}{l}\text { Izvairīšanās no emociju } \\
\text { nosaukšanas }\end{array}$ & $\begin{array}{l}\text { Izjūtas būtu atkarīgas no citiem apstāklliem, } \\
\text { piemēram, "konkrētā skolnieka" vai "sava } \\
\text { noskaṇojuma“. }\end{array}$ \\
\hline \multirow[t]{2}{*}{ Pārsteigti } & Pārsteigums & "Būtu pārsteigta". \\
\hline & Apmulsums & "Sākumā apmulsusi”. \\
\hline \multirow[t]{2}{*}{ Emocionāli neitrāli } & Mierīgi & "Justos mierīgi", "ikdienišķa situācija", \\
\hline & Normāli & “Tur nav jau iemesla justies labi vai slikti”. \\
\hline Citas izjūtas & Žèlums & "Žèl meitenes". \\
\hline
\end{tabular}

Negatīvi - skolotāji min dažādās intensitātes negatīvas emocijas - dusmas, vilšanos, izmisumu. Runājot par šìm izjūtām, lieto arī aprakstošus apzīmējumus, piemēram, "ḷoti smagi", "diezgan grūti", "loti nepatīkami”. Nevar pateikt, ko izjūt - skolotāji runā par to, ka nezina, kādas būtu izjūtas, runā arī par emociju neesamību "nekādu emociju nebūtu", arī stāsta, ka izjūtas būtu atkarīgas no citiem apstākḷiem, piemēram, "konkrētā skolnieka" vai "sava noskaņojuma“. Pārsteigti - skolotājs min, ka izjustu pārsteigumu, samulsumu, neizpratni, apjukumu, piemēram, "sākumā apmulsusi", "būtu pārsteigta".

Emocionāli neitrāli - skolotāji runā par to, ka situācija ir ikdienišķa, parasta, normāla, un ka viṇi justos mierīgi, normāli, ka nav iemesla negatīvām izjūtām, piemēram, "tur nav jau iemesla justies labi vai slikti".

Citas izjūtas - skolotājs runā nevis par konkrētām izjūtām, bet apraksta savu lomu situācijā, piemēram, "kārtējais starpgadījums, kur atkal ir vajadzīga mana palīdzība", kā arī piemin, ka izjustu žělumu pret kādu skolnieku.

Lai atbildētu uz pētījuma otro jautājumu, vai pastāv saistība starp skolotāju minētajiem skolēnu uzvedības motīviem un skolotāju pašprognozēto uzvedības reakciju, tika veidotas četras augstāka vispārinājuma kategorijas, lai saistības varētu 
skatìt visās trīs pētījumā izmantotajās situācijās kopā. Atbilstoši atribūcijas teorijai, tika pētīta saistîba starp Negatīviem motīviem, Neitrāliem/pozitīviem motīviem no vienas puses un Negatīvu un Neitrālu/pozitīvu uzvedības reakciju. Pie Neitrāliem/ pozitīviem motīviem tika pieskaitìtas 3 izdalìtās motīvu kategorijas: Situatīvi neitrāli motīvi ("viņam vajadzēja iziet", "viņš kaut ko meklēja”), Ar personību saistīi pozitīivi un neitrāli motīvi ("viņš ir kārtīgs puisis" "viṇa nekad neko nenomet") un Citi pozitīvi un neitrāli iemesli. Negatīvu motīvu grupā tika apvienotas 3 kategorijas: Situatīvi negatīvi iemesli ("viņš nebija sagatavojies stundai"), Ar personības iezīmēm, prasmēm saistīti negatīvi motīvi ("uzmanības problēmas," "iedomīga", "psihiskas novirzes"), un Citi stabili negatīvi iemesli ("problēmas ǵimenē", "nepatika pret skolu, mācību priekšmetu”).

Skolotāju pašprognozētās uzvedības kategorijā Neitrāla/pozitīva reakcija apvienotas trīs tēmas: Pasiva rīcība ("man nepatīk iesaistìties citu konfliktos", "es turpinātu stundu"), Aktīva neitrāla rīcība ("ietu pakal un noskaidrotu", "izskaidrotu, ka tādi ir noteikumi”) un Atbalstoša rīcība ("pastāvētu blakus, līdz viņš iesāk rakstìt un pamudinātu - re, labi...”). Tēma Aktīva negatīva rīcība neapvieno citas kategorijas, bet gan tikai satura vienības (" neviens no klases neies laukā, kamēr nav savākti papīri", "ja viņam būtu vienalga, tad sazinātos ar vecākiem”). No šiem četriem mainīgajiem tika izveidota tabula, kurā atkārtoti tika kodētas satura vienības.

Lai salīdzinātu motīvu skaidrojumu, skolotāju rīcību un izjūtas visu trīs situāciju griezumā, izdalītās satura vienības tika apvienotas tēmās. Saturiski saskanīgās tēmas tika apvienotas kategorijās. Kategoriju izveidē tika izmantoti atribūcijas teorijas pieñēmumi par motīvu dimensijām - stabilitāti, tǐšumu, kontrolējamību - un atbildes reakcijas atbalstošo vai nosodošo raksturu. Visbiežāk skolēnu uzvedība tiek skaidrota ar situatīvi neitrāliem iemesliem (30,5\%) (skat. 4. tabulu). Gandrīz tikpat bieži skolotāji kā iemeslu skolēnu uzvedībai min situatīvi negatīvus iemeslus $(26,8 \%)$. Kā trešo biežāko motīvu skolotāji min negatīvas personības dispozīcijas $(24,2 \%)$.

\section{4. tabula. Skolotāju skaidrojuma par skolēnu problemātiskās rīcības motīviem absolūtie un relatīvie biežumi visās trīs piedāvātajās situācijās}

\begin{tabular}{lcccc}
\hline \multicolumn{1}{c}{ Skolotāja piedèvētais skolēna rīcības motìvs } & 1. situācija & 2. situācija & 3. situācija & Visās kopāa \\
\hline Situatīvi neitrāli iemesli & $18(24,7 \%)$ & $25(39,7 \%)$ & $15(27,8 \%)$ & $58(30,5 \%)$ \\
Situatīivi negatīvi iemesli & $22(30,1 \%)$ & $13(20,6 \%)$ & $16(29,6 \%)$ & $51(26,8 \%)$ \\
Negatīvas personības tendences & $18(24,7 \%)$ & $14(22,2 \%)$ & $14(25,9 \%)$ & $46(24,2 \%)$ \\
Pozitīvas un neitrālas personības dispozīcijas & $9(12,3 \%)$ & $6(9,5 \%)$ & $6(11,1 \%)$ & $21(11,1 \%)$ \\
Negatīvi ārējie iemesli & $6(8,2 \%)$ & $1(1,6 \%)$ & $3(5,6 \%)$ & $10(5,3 \%)$ \\
Ar vienaudžu attiecībām saistīti iemesli & & $4(6,3 \%)$ & & $4(2,1 \%)$ \\
\hline
\end{tabular}

Visās situācijās visbiežāk skolotāji rīkotos aktīvi neitrāli (60,7\%) (skat. 5. tabulu). Otra biežākā reakcija būtu atbalstoša (18,8\%). Trešā visbiežākā rīcība būtu - pasīva (10,7\%). Visretāk skolotāji rīkotos aktīi negatīvi $(9,8 \%)$. 
5. tabula. Skolotāju uzvedības reakcijas absolūtie un relatīvie biežumi visās trīs piedāvātajās situācijās

\begin{tabular}{lcccc}
\hline \multicolumn{1}{c}{ Skolotāja pašprognozētā reakcija } & 1. situācija & 2. situācija & 3. situācija & Visās kopā \\
\hline Aktīva neitrāla reakcija & $29(60,4 \%)$ & $20(66,7 \%)$ & $18(58,1 \%)$ & $67(60,7 \%)$ \\
Atbalstoša reakcija & $7(14,6 \%)$ & $5(16,7 \%)$ & $9(29,0 \%)$ & $21(18,8 \%)$ \\
Pasīva reakcija & $10(20,8 \%)$ & $1(3,3 \%)$ & $1(3,2 \%)$ & $12(10,7 \%)$ \\
Aktīva negatīva & $2(4,2 \%)$ & $4(13,3 \%)$ & $3(9,7 \%)$ & $11(9,8 \%)$ \\
\hline
\end{tabular}

Visās situācijās visbiežāk skolotāji justos Negatīvi $(45,5 \%)$ (skat. 6. tabulu). Trīs reizes retāk skolotāji Nezina, kā justos (16,7\%), gandrīz tikpat bieži skolotāji justos Emocionāli neitrāli (15,2\%).

6. tabula. Skolotāju izjūtu absolūtie un relatīvie biežumi visās trīs piedāvātajās situācijās

\begin{tabular}{lcccc}
\hline \multicolumn{1}{c}{ Skolotāja izjūtas } & 1. situācija & 2. situācija & 3. situācija & Visās kopā \\
\hline Negatīvas & $12(36,4 \%)$ & $11(61,1 \%)$ & $7(43,8 \%)$ & $30(45,5 \%)$ \\
Nezina, kā justos & $9(27,3 \%)$ & $1(5,6 \%)$ & $1(6,7 \%)$ & $11(16,7 \%)$ \\
Emocionāli neitrālas & $4(12,1 \%)$ & $1(5,6 \%)$ & $5(33,3 \%)$ & $10(15,2 \%)$ \\
Pārsteigums & $8(24,2 \%)$ & $1(5,6 \%)$ & & $9(13,6 \%)$ \\
Citas izjūtas & & $4(22,2 \%)$ & $2(13,3 \%)$ & $6(9,1 \%)$ \\
\hline
\end{tabular}

Lai noteiktu saistību starp skolotāju skaidrojumu par skolēnu uzvedības motīviem un skolotāju uzvedības reakciju, tika izveidotas augstāka vispārinājuma kategorijas, proti, jau esošās kategorijas tika apvienotas saskaṇā ar atribūcijas teorijas nostādnēm. Skolotāja skaidrojumam par skolēnu uzvedības motīviem tika izveidotas kategorijas Negatīvs motīvs un Neitrāls/pozitīvs motīvs un skolotāja pašprognozētajai uzvedības reakcijai tika izveidotas kategorijas - Neitrāla/pozitīva reakcija un Negatīva reakcija (skat. 7. tabulu). Saistības aprēḳināšanai tika izmantots $\chi 2$ tests. Saskaṇā ar tā rezultātiem pastāv statistiski nozīmīga saistība starp skolotāju skaidrojumu par skolēnu uzvedības motīvu un savu prognozēto uzvedības reakciju $\chi^{2}=8,1, p<0,05$. Tas nozìmē: ja skolotāja skolēnu uzvedību skaidro ar negatīvākiem motīviem (gan ar situatīviem, gan stabilākiem, piemēram, personības iezīmes, gan arī ārējiem, ārpus skolēna kontroles esošiem, piemēram, gimenes situācija), tad skolotāja pašnovērtētā uzvedības reakcija biežāk ir nosodoša. Un otrādi: ja skolēna rīcības motīvs tiek skaidrots ar pozitīviem vai neitrāliem iemesliem - gan situatīviem, gan ar stabiliem, piemēram, personības iezīmes, tad skolotāja prognozētā uzvedības reakcija ir mazāk nosodoša.

7. tabula. Skolotāju skaidrojuma par skolēnu uzvedības motīviem un skolotāju prognozētās uzvedības reakcijas absolūtie un relatīvie biežumi visās trīs piedāvātajās situācijās

\begin{tabular}{lcc}
\hline & \multicolumn{2}{c}{ Skolotāja skaidrojums par skolēna uzvedības motīvu } \\
\hline \multicolumn{1}{c}{ Skolotāja uzvedības reakcija } & Negatīvs motīvs & Neitrāls/pozitìvs motīvs \\
\hline Neitrāla vai pozitīva reakcija & $107(52,7 \%)$ & $83(40,8 \%)$ \\
Negatīva reakcija & $11(5,4 \%)$ & $2(1,1 \%)$ \\
\hline
\end{tabular}




\section{Diskusija}

Atbildot uz pētijjuma jautājumu par to, kā skolotājas skaidro skolēnu problemātiskas uzvedības motīvus, var secināt, ka pētāmajā grupā skolotājas visbiežāk skolēna rīcíbu skaidro ar situatīviem iemesliem un tikai aptuveni trešdaļa motīvu tiek skaidroti ar personības dispozīcijām. Aptuveni ceturtā daḷa motīvu tiek skaidroti ar negatīvām personības dispozīcijām, piemēram, "tāds ir viṇa psihologiskais tips". Visu trīs situāciju griezumā proporcija starp situatīvu skaidrojumu un skaidrojumu ar personības dispozījām ir samērā stabila. Var secināt, ka skolotājas saprot un atzīst situatīvo faktoru nozīmi skolēna uzvedības motivācijā. Šis pētijuma secinājums dạ̦ēji ir pretrunā ar atribūcijas teorijas pamatnostādnēm, kas apgalvo, ka, novērtējot kāda cita negatīvi iekrāsotu rīcību, cilvēkiem ir tieksme nenovērtēt situatīvo faktoru nozīmi un pārvērtēt personisko faktoru nozīmi (piemēram, Jones \& Nisbett, 1971; Fiske, 2004, kā minēts Reñge, 2002.). Tomēr nevar teikt, ka skolēnu personības dispozīcijām skolotāju skaidrojumā par skolēnu rīcības motīviem ir pavisam nenozīmìga loma. Ar personības dispozīcijām skolotāji skaidro aptuveni trešdalı skolēnu uzvedības motīvu, piemēram, "visticamāk ir l̦oti apzinīgs skolēns", "acīmredzot, mācības viņam nav pirmajā vietā".

Ārējie, skolēnam nekontrolējamie apstākḷi motīvu skaidrojumā ir minēti reti, visbiežāk tiek minēti vecāki un gimene, veselības problēmas, arī klases noteikumi. Tas saskan ar citu pētnieku atziņām, ka skolotājiem ir tendence problemātiskas uzvedības un mācību grūtību cēloṇus biežāk piedēvēt skolniekiem, nevis saviem mācišanas, audzināšanas pan̄ēmieniem un attieksmei (Aldrich \& Martens, 1993; Athanasiou et al., 2002).

Atbildot uz pētijuma jautājumu, kāda ir skolotāju uzvedības reakcija situācijās ar skolēnu problemātisku uzvedību, var secināt, ka reakcija visās trīs situācijās parāda samērā stabilu paternu: $60 \%$ gadījumu skolotāji rīkotos aktīvi neitrāli, piemēram, "pārrunātu situāciju ar abiem skolēniem", "apjautātos, vai tiešām viņam ir grūti un nav skaidrs", gandrīz 20\% gadỉjumu būtu atbalstoši, aptuveni $10 \%$ gadījumu būtu pasīvi pret konkrēto skolēnu un gandrīz tikpat bieži rīkotos aktīvi negatīvi, piemēram, norātu skolēnu vai rakstītu piezīmi.

Attiecībā uz aktīvi neitrālu rīcību skolotāji visbiežāk argumentētu un uzturētu noteikumus, censtos noskaidrot, kas noticis un pārrunātu ar skolniekiem notikušo. Iespējams, ka šāda aktīva neitrāla reakcija šajā pētijumā ir atspoguḷota vairāk, nekā tāda būtu reālā dzīvē. Tam var būt divi iemesli: pirmkārt, tiešās intervijās skolotājiem varētu būt diezgan liela vēlme sniegt sociāli vēlamas atbildes. Otrs iemesls varētu būt saistīts ar kategoriju veidošanas procedūru. Kategorijā aktīva neitrāla reakcija tika ieklıautas visas satura vienības, kurās skolotāji norāda, ka "runātu" ar skolēnu, "pārrunātu", taču reālā situācijā pārrunas var būt ar ḷoti atškịirīgu emocionālo nokrāsu, kuru lielā mērā nosaka ne vien verbālais saturs, bet arī neverbālais. Šajā gadījumā to nebija iespējams novērtēt. Lìdz ar to var gadīties, ka kategorijā Aktīva neitrāla reakcija ir arī tādas satura vienības, kas drīzāk būtu attiecināmas uz Aktīvu negatīvu reakciju vai arī uz Atbalstošu reakciju, ja saruna ar skolēnu ir iejūtīga, vērsta uz sapratni.

Analizējot skolotāju atbalstošo reakciju var secināt, ka visbiežāk šādu uzvedību skolotāji izpaustu dežurantu situācijā. Iespējams, ka šajā gadījumā skolotāji ir gatavi 
biežāk sniegt atbalstu, jo skolotāja ir pati aktīva situācijas daḷa, nevis novērotājs kā abās pārējās situācijās.

Kopumā mācību situācijā atbalsts tiek sniegts salīdzinoši retāk nekā citās situācijās. Iespējams, ka tas ir saistīts ar šajā pētījumā nemērīto uzvedības kontrolējamības dimensiju. Ja pieṇem, ka lielu daļu no skolotāju nosauktajiem skolēnu uzvedības motīviem, kurus skolotāji nosauc par situatīviem, skolotāji novērtē kā skolēnam kontrolējamus, piemēram, "nav gatavs stundā strādāt", tad var domāt, ka skolotāja skolēnu uzskata par atbildīgu par šo uzvedību. Saskaṇā ar Veinera teoriju: ja negatīvas uzvedības motīvs ir kontrolējams, tad reakcija ir drīzāk nosodoša. Šajā pētījumā nosodoša reakcija kā kategorija netika izdalīta - jau minēto iemeslu dēḷ. Turklāt tikai $10 \%$ gadījumos reakcija tika kategorizēta kā Aktīva negatīva, piemēram, aizrādītu vainīgajam. Saskaṇā ar citiem autoriem, jo skolotāji ir pārliecinātāki, ka skolēni ir atbildīgi par vājiem mācību rezultātiem, jo biežāk šie skolēni saṇem brīdinājumus un kritiku (Medway, 1979; Cooper \& Burger., 1980). No šī pētījuma par to nevar spriest.

No visām situācijām visbiežāk skolotāji pasīvi rīkotos mācību situācijā - nepievērstu uzmanību konkrētajam skolēnam. Kaut arī atbilžu skaits ir neliels, tomēr, iespējams, tā parāda ievirzi, ka skolotājiem ir tendence censties ignorēt skolēnu problemātisku uzvedību. Pasīva reakcija pret konkrēto skolēnu pētījuma situācijā atspoguḷo arī to, ka skolotājiem nākas izvēlēties starp uzmanības fokusu uz mācību procesu un klasi kopumā un uz atsevišḳu skolēnu, kas šajā gadījumā iziet no klases.

Pētījums parāda, ka tikai 10\% gadījumu skolotāju pašprognozētā reakcija būtu aktīvi negatīva - aizrādītu skolniekam, neḷautu iziet no klases, aizstātos durvīm priekšā. Iespējams, ka ši iedomātā reakcija neatspoguḷo skolotāju reakciju dzīvē, bet gan vēlamību, kā jau iepriekš minēts divu iemeslu dēḷ - skolotāju sociāli vēlamo atbilžu dēl, kā arī pētījuma dizaina un procedūras dēḷ.

Analizējot skolotāju emocionālo un uzvedības reakciju, interesanti atzīmēt lìdzjūtības saistību ar skolotāja paša pieredzi. Saskaṇā ar Veinera teoriju: ja skolotāji skolēnu neveiksmi skaidro ar spēkiem, kas bija ārpus skolēna kontroles, piemēram, sliktu veselību vai autobusu, kas neatnāca laikā, tad skolotājiem bija tendence just līdzi skolēniem un izvairīties viņus nosodīt. Šajā pētījumā viens spilgts piemērs šādai saiknei starp uzvedības skaidrojumu un skolotājas reakciju ir mācību situācijā. Skolotāja skolēna iziešanu skaidro ar to, ka viņš ir iestrēdzis zaudētāja lomā, zaudējis ticību saviem spēkiem, viṇa to saista ar neveiksmēm kādā mācību priekšmetā un viṇas pašprognozētā reakcija būtu - palīdzēt atgūt zēnam ticību saviem spēkiem. "Es atrastu variantu, ka viņš notic sev, ka var - kaut vai sīkumu, bet pats līdz galam!”, saka skolotāja. Tātad varētu būt, ka skolotājas pašas personīgā pieredze būtiski ietekmē, kā skolotāja novērtē skolēna uzvedību un kāda ir skolotāja reakcija.

Negaidīti secinājumi saistās skolotāju pašnovērtētajām izjūtām. Pētījums parāda, ka skolotāji par savām izjūtām izsakās ne vien l̦oti skopi, bet arī samērā bieži īsti nezina, kā justos (17\% gadījumu). Ja skolotāji nezina, ko viṇi justu, īsti neizprot, ar ko ir saistīta emociju intensitāte, tad savu uzvedības reakciju ir grūtāk vadīt, kā viena skolotāja saka: "Sabl̦auju un nesaprotu - kāpēc?" No atbildēm noprotams, ka daļa skolotāju nelabprāt atzīst - esmu dusmīga, jaušams arī emociju noliegums (piemēram, "nebūtu dusmas uz 
skolēnu", "neko nejustu"). No tā var secināt, ka daļai skolotāju, iespējams, ir grūtības būt kontaktā ar savām izjūtām, it īpaši stiprām negatīvām izjūtām.

Attiecībā par skolotāju pašprognozētajām izjūtām, jāpiemin arī skolēna problemātiskās uzvedības stabilitātes dimensijas lomu. Skolotāji atzīst, ka izjūtas būtu atkarīgas no tā, vai skolnieks tādā veidā - piemēram, iziet no klases stundas laikā vai iesper klases biedram - izdara pirmo reizi vai atkārtoti. Tomēr šajā ziṇā ir diametrāli pretējas skolotāju atbildes: viena, piemēram, saka, ka justos mierīgi, ja tas notiek atkārtoti, cita saka - "justos ḷoti dusmīga, ja mans Arvis desmito reizi to dara." Pēdējais piemērs saskan ar literatūrā pieminēto stabilitātes dimensijas ietekmi, ka skolēniem, kuru uzvedība ir problemātiskāka, var gadīties grūti izrauties no viņa uzvedības motīvu un attiecīgi arī reakcijas ietekmes (Gibss \& Gardiner, 2008; Dobbs \& Arnold, 2009). Ikdienas valodā skolēni saka: skolotājs uz mani ir uzēdies.

Atbildot uz pētījuma otro jautājumu par saikni starp skolēna uzvedības motīvu un skolotāja reakciju, pētījuma rezultāti apstiprināja, ka saikne pastāv. Tas saskan ar teorijas atzin̄ām: ja skolotājs novērtē motīvu kā negatīvu, kas ietver tǐšu, stabilu, kontrolējamu, tad skolotāja reakcija ir vērsta uz nosodijumu, savukārt, ja motīvs tiek skaidrots kā netî̌s, nestabils, pozitīvs, tad atbildes reakcija drīzāk ir neitrāla vai tā ir vērsta uz atbalstu (Weiner, 2003).

Pētijumam ir vairāki ierobežojumi. Pirmkārt, dati tiek ievākti tiešā sarunā ar respondentiem, līdz ar to datu ievākšanu var ietekmēt attiecỉbas starp intervētāju un respondenti, kaut arī tika ievērota vienota procedūra. Otrkārt, pētijima rezultātos it îpaši skolotāju viedoklī par savu uzvedības un emocionālo reakciju - varētu tikt iegūtas sociāli vēlamas atbildes. Treškārt, skolotāju uzvedības reakciju kategorizācijā izmantotie verbālie un satura kritēriji nepietiekami atspoguḷo reālo dzīves situāciju, jo reakcijas emocionālo virzienu (pozitīvs, neitrāls vai negatīvs) būtiski ietekmē neverbālie izteiksmes līdzekḷi - balss, intonācija, žesti, kas šajā gadījumā netika ṇemti vērā.

Pētījums par skolēnu problemātiskas uzvedības skaidrojumu un skolotāju uzvedības un emocionālo reakciju apstiprina, ka pastāv saistība starp uzvedības motīva skaidrojumu un skolotāja uzvedības reakciju. Negatīvāks motīva skaidrojums izraisa negatīvāku atbildes reakciju, un otrādi; ja skolotājas skolēna uzvedības motīvu novērtē kā pozitīvu, tad atbildes reakcija ir mazāk negatīva. Skolotājas skolēnu uzvedību biežāk skaidro ar situatīviem iemesliem, trīs reizes retāk ar dispozicionāliem faktoriem.

Skolēnu uzvedības motīvu skaidrojumā skolotājas mazu lomu pievērš ārējiem apstākḷiem. Skolas vides, mācību procesa loma skolotāju skaidrojumos gandrīz netiek pieminèta.

Pētāmajā grupā skolotājām, saskaroties ar skolēnu problemātisku uzvedību, ir grūtibas saprast savas emocijas.

Turpmākajos pētijumos par skolēnu problemātiskas uzvedības ietekmi būtu vērts vairāk pievērsties skolotāju pašu izpratnei par to, kā viṇu dzīves pieredze, pārliecības, emocijas ietekmē reakciju uz skolēnu problemātisko uzvedību. Tāpat būtu lietderīgi pētìt skolēnu problemātiskas uzvedības skaidrojumu un skolotāju reakciju skolas videi pietuvinātākos apstākḷlos, nevis, izmantojot hipotētiskus situāciju aprakstus. 


\section{Izmantotā literatūra}

Achenbach, T. M., \& Rescorla, L. A. (2001). Manual for ASEBA School-Age Forms \& Profiles. Burlington, VT: University of Vermont, Research Center for Children, Youth.

Alvarez, H. K. (2007). The impact of teacher preparation on responses to student aggression in the classroom. Teaching and teachers Education 23, 1113-1126.

Athanasiou, M. S., Geil, M., Hazel, C. E., \& Copeland, E. P. (2002). A look inside school-based consultation: a qualitative study of the beliefs and practices of school psychologists and teachers. School Psychology Quarterly, 17 (3), 258-298.

Bibou-Nakou, I (2000). Elementary school teachers representations regarding school problem behaviour. Educational and Child Psychology 17 (4), 91-1.

Cooper, H. M., \& Burger, J. M. (1980). How teachers explain students' academic performance: a ategorization of free response academic attributions. American Educational Research Journal, 17, 95-109.

Dobbs, J., \& Arnold, D. H. (2009). Relationship between preschool teachers' reports of children's behavior and their behavior toward those children. School Psychology Quarterly, 24(2), 95-105.

Gibbs, S., \& Gardiner, M. (2008). The structure of primary and secondary teachers' attributions for pupils'misbehaviour: a preliminary cross-phase and cross-cultural investigation. Journal of Research in Special Educational Needs, 8 (2), 68-77.

Kelley, H. H. (1967). Attribution theory in social psychology. In D. Levine (Ed.), Nebraska Symposium on Motivation, 15, 192-240. Lincoln, NE: University of Nebraska Press.

Medway, F. J. (1979). Causal attributions for school-related problems: teacher perceptions and teacher feedback. Journal of Educational Psychology, 71(6), 809-818.

Pirsko, L. (2010). Piesaistes stila saistība ar uzvedības traucējumiem un bērnu un vecāku vardarbības pieredzi. LU [Online] Extracted from http://www.lu.lv/bibliotēka

Reñgè, V. (2002). Sociālā psiholog̣ija. Rīga: Apgāds Zvaigzne ABC.

Reyna, C., \& Weiner, B. (2001). Justice and utility in the classroom: an attributional analysis of the goals of teachers' punisment and intervention strategies. Journal of Education Psychology, 93 (2), 309-319.

Riley, P., Lewis, \& R., Brew, K. (2010). Why did you do that? Teacher explain the use of legal aggression in the classroom. Teaching and Teacher Education 26, 957-964.

Snyder, J., Cramer, A., Afrank, J., \& Patterson, G. R. (2005). The contributions of ineffective discipline and parental hostile attributions of child misbehavior to the development of conduct problems at home and school. Developmental Psychology, 41 (1), 30-41.

Weiner, B. (2003). The classroom as a courtroom. Social Psychology of Education, 6, 3-15.

Wickens, C. M., Wiesenthal, D. L., Flora, D. B., \& Flett, G. L. (2011). Understanding driver anger and aggression: attributional theory in the driving environment. Journal of Experimental Psychology, 17 (4), 354-370. 


\title{
Noguruma un gulētiešanas laika novilcināšanas saistība ar prokrastināciju skolotājiem
}

\author{
Ginta Slišāne un Baiba Martinsone ${ }^{1}$ \\ Latvijas Universitāte
}

\begin{abstract}
Abstrakts
Šis pētījums ir par noguruma un gulētiešanas laika novilcināšanas saistību ar prokrastināciju skolotājiem. Pētījuma mērḳis bija pārbaudìt, kā skolotāju noguruma un prokrastinācijas kā iezīmes rādītāji prognozē gulētiešanas laika novilcināšanu. Atsevišķs pētījuma jautājums bija vērsts uz to, kā virsstundu darbs prognozē gulētiešanas laika novilcināšanu skolotājiem. Pētāmo grupu veidoja 229 skolotāji - 26 vīrieši (11\%) un 203 (89\%) sievietes ar vidējo vecumu 43,6 gadi. Rezultāti atklāja, ka skolotāji ar augstākiem rādītājiem prokrastinācijā kā personības iezīmē un lielāku nostrādāto virsstundu skaitu uzrādīja augstākus rādītājus gulētiešanas laika novilcināšanā. Tika konstatēts, ka skolotāju nogurums neprognozē gulētiešanas laika novilcināšanu.
\end{abstract}

Atslēgas vārdi: Prokrastinācija, gulētiešanas laika novilcināšana, nogurums.

\section{Teachers' Fatigue and Bedtime Delay in Relation to Procrastination}

\author{
Ginta Slišāne and Baiba Martinsone
}

University of Latvia

\begin{abstract}
This focus of this research is on teachers' fatigue and bedtime delay in relation to procrastination. The main purpose of this research was to clarify the association between higher procrastination trait and fatigue ratings as predictors of bedtime procrastination. The main question of this study was how teachers' working overtime predicts bedtime procrastination. Were questioned $\mathrm{N}=229$ teachers with average age $\mathrm{M}=43,66$ ( $\mathrm{SD}=11.57$ ), from which $26(11 \%)$ were men and 203(89\%) were women. Overall results showed that teachers' procrastination as a personality trait and working overtime significantly predicted bedtime procrastination ratings. Fatigue did not predict bedtime procrastination.
\end{abstract}

Keywords: procrastination, bedtime procrastination, fatigue.

Pēdējos 40 gadus prokrastinācija psihologijias zinātnē tiek pētīta dažādos aspektos gan klīniskajā nozarē, gan akadēmiskajā sfērā, gan veselības jomā. Daudzos pētījumos ir atrasti pierādījumi, ka prokrastinācija ir izplatīta un problemātiska (Steel, 2007). Prokrastinācija ir apzināta, brīoprātīga ieplānoto darbu atlikšana, tā vietā darot kādus

1 Corresponding author: Baiba Martinsone, University of Latvia, Jurmalas gatve 76, Riga LV-1083, Latvia. Email: baiba.martinsone@lu.lv 
patīkamākus, maznozīmīgākus darbus, tādējādi pavirzot svarīgos darbus uz vēlāku laiku (Steel, 2007). Cilvēki stratēgiski pievēršas mazāk svarīgu darbu veikšanai un atliek augstākas svarīguma pakāpes darbus, kur nepieciešama lielāka kognitīva iesaiste. Piemēram, tā vietā, lai veiktu apjomīgu darbu, kura pabeigšanas termiņš tuvojas, cilvēks pēta jaunāko informāciju ziṇu portālos, skatās internetā video vai dara citus maznozīmīgākus darbus (Ariely \& Wertenbroch, 2002). Prokrastinācija ir saistīta arī ar pazeminātu spēju sevi kontrolēt. Pētījumi studentu vidē parāda, ka tie, kuri izvēlas atlikt darbus, vairāk cieš no stresa, piedzīvo vairāk veselības problēmas un viniem ir zemāki sasniegumi salīdzinājumā ar tiem, kuriem ir labāka sevis kontrolēšanas spēja (Steel, 2007; Steel et al., 2001; Tice \& Baumeister, 1997).

Hariots un Ferari (Harriott \& Ferrari, 1996) atklāja, ka 20\% no pieaugušo populācijas piedzīvo hronisku prokrastināciju. Tomēr lielākā dạ̦a pētījumu galvenokārt ir vērsti tieši uz akadēmisko prokrastināciju, nevis uz darba vietām. Tas pamato šì pētijuma aktualitāti, n,emot vērā to, ka prokrastinācija var negatīvi ietekmēt organizāciju, samazinoties darbinieka darba spējām (Steel, 2007). Pētỉjumi rāda, ka vairāk nekā 95\% prokrastinēto indivīdu vēlas samazināt darbu novilcināšanu (O’Brien, 2002). Pētnieki ir nonākuši pie secinājuma, ka prokrastinācija ir noturīga laikā un dažādās situācijās (Steel, 2007).

Šūvenburgs un Groenvuds (Schouwenburg \& Groenewoud, 2001) raksta, ka prokrastinācija ir izplatīta un, ka neliels daudzums prokrastinācijas ir normāla cilvēka uzvedība. Daudzi cilvēki prokrastinē kādā savas dzīves posmā vai konkrētā sfērā vairāk un kādā - mazāk. Prokrastinēšana var ietekmēt uzdevuma izpildi un novēlot mērķa sasniegšanu. Metaanalīze parāda, ka pastāv negatīva korelācija starp prokrastināciju un atzīmēm skolā (Steel, 2007). Tas nozīmē, ka augstāki prokrastinācijas rādītāji ir saistīti ar zemākiem akadēmiskajiem sasniegumiem. Subjektīvais sasniegumu novērtējums var tikt pazemināts prokrastinācijas rezultātā, kas var ietekmēt pašefektivitāti un bailes no izgāšanās (Krause \& Freund, 2014). Pētijumi rāda, ka prokrastinācijas rezultātā studenti piedzīvoja lielāku nogurumu, stresu, vainas apziņu un zemāku dzīves kvalitāti (Schraw, Wadkins, \& Olafson, 2007). Indivīdi, kuri prokrastinē jau pašā sasniedzamā mērķa sākumā, piedzīvo mazāku stresu un dažādus fiziskos simptomus, nekā tie indivīdi, kuri prokrastinē salīdzinoši retāk. Indivīdi, kuri prokrastinē pašā darba sākumā, lielāku stresu piedzīvo tieši tad, kad mērḳis jau ir tuvu un viniem ir arī augstāka fizisko simptomu izteiktiba (Tice \& Baumeister, 1997).

Viens no skaidrojumiem, kāpēc rodas prokrastinācija, ir vēlme izvairīties no negatīvām emocijām un stresa, kādas neizbēgami rada saspringts darbs. Prokrastinācijas iemesls var būt arī neapzinātas bailes no sekām un rezultāta, kas radīsies darba procesā. Prokrastinācijas pamatā varētu būt arī neapzinātas bailes no veiksmes, uzvaras un izdošanās, jo tās varētu uzlikt jaunus pienākumus, tātad jaunu stresu. Savukārt prokrastinācijas sekas var būt vainas izjūta par nepadarīto vai nepietiekami kvalitatīvi padarito (Rubene, 2013).

Iepriekšējie pētijumi ir identificējuši, ka bailes no izgāšanās, bailes no uzdevuma kā tāda un pazemināta pašefektivitāte ir centrālie mainīgie, kas paredz prokrastinācijas veidošanos (Wolters, 2003). Ir atrasts apstiprinājums, ka sākumskolas skolotāju izlasē akadēmisko prokrastināciju nozīmīgi prognozē tādi mainīgie kā slinkums, bailes 
kḷūdīties un pazemināta mācību motivācija (Saracalogly \& Gokdas, 2016). Pētījumi rāda, ka tieši pazemināta pašefektivitāte ir ḷoti cieši saistīta ar prokrastināciju un prokrastinācijas radītais stress pasliktina kopējo veselību pieaugušajiem (Sires, 2014).

Jauns prokrastinācijas pētījumu virziens mūsdienās ir gulētiešanas laika novilcināšana; šis virziens ir novedis pie jauniem atklājumiem veselības psiholog̣ijā. Gulētiešanas laika prokrastinācija ir svarīgs faktors, kas noved pie miega problēmām un konsekventi ietekmē indivīda kopējo veselības stāvokli un darba kvalitāti. Gulētiešanas laika prokrastinācija tiek definēta kā neizdošanās aiziet gulēt noliktajā laikā, lai arī nepastāv nekādi apkārtējie apstākḷi, kas varētu no tā atturēt. Ir atklāts, ka cilvēki, kuri atliek gulētiešanu, to dara nevis tāpēc, ka vēlētos palikt nomodā ilgāk, bet gan tāpēc, ka nevēlējās pārtraukt darìt to, ko bija uzsākuši (Adriaanse, De Ridder, Evers, \& Kroese, 2014).

Saskaṇā ar pētỉjumiem tipiskiem prokrastinatoriem ir raksturīgas zemākas pašregulācijas iemaņas (Pietrzak \& Tokarz, 2016), līdz ar to ir zemāka spēja pretoties kārdinājumiem. Pašregulācija attiecas uz cilvēka centieniem pašam mainīt savas domas, jūtas, vēlmes un darbības attiecībā pret saviem turpmākajiem mērḳiem. Pētnieki norāda, ka šiem cilvēkiem ir grūtības aiziet gulēt noliktajā laikā, neņemot vērā vinu apṇemšanos. Ir atrastas pirmās norādes saistỉbai starp pazeminātu pašregulāciju un gulētiešanas laika novilcināšanu (Kroese et al., 2014), proti, ka zemāki pašregulācijas rādītāji ir saitīti ar augstākiem gulētiešanas laika novilcināšanas rādītāiiem. Secinājums, ka nepietiekams miegs ir saistīts ar pašregulācijas grūtībām, var tikt attiecināts arī uz citām darbībām, piemēram, novēlotu ārstu apmeklēšanu u.c. (Adriaanse et al., 2014).

Novilcinot gulētiešanu, miegam tiek atvēlēts mazāks stundu skaits. Nepietiekams miegs var izraisìt nopietnas sekas, kas var ietekmēt indivīda garīgo un fizisko veselïbu. Piemēram, pētỉjumi rāda, ka miega trūkums ir saistīts ar koncentrēšanās grūtībām un atmiņas problēmām (Ram, Seirawan \& Kumar et al., 2010), kardiovaskulārām saslimšanām un aptaukošanos (Buxton \& Marcelli, 2010). Ir arī novērots, ka vidējais miega stundu skaits kopējā populācijā ir ievērojami samazinājies pēdējās dekādes laikā (National Sleep Foundation, 2005). Tomēr lielākā daļa pētījumu ir koncentrējušies uz nepietiekamu miegu, kas ir saistìts ar miega traucējumiem vai ārējiem faktoriem, nevis prokrastināciju. Jaunākie pētījumi rāda, ka nepietiekams miegs kopējā populācijā jau tiek uzskatīts par tipisku veselības uzvedības problēmu, kur nodoms iet gulēt ne vienmēr saskan ar faktisko rīcíbu (Adriaanse, Evers, Kroese, Marieke, \& Ridder, 2014).

Cilvēka diennakts režìmam ir sarežğìta mijiedarbība ar ikdienas uzvedību. Pētijumi rāda, ja indivīdam ir regulārs gulētiešanas laika grafiks katru dienu, tad tas stiprina diennakts ritmu un ir galvenais faktors dzilam, veselīgam un kvalitatīvam miegam. Dažkārt pat viena vakara atkāpšanās no grafika var radīt grūtības ar gulētiešanu turpmāk un miega kvalitāti. Zinātnieki norāda, ka pat divu stundu nobīde no gulētiešanas režīma, nemainot kopējo gulēto stundu skaitu, var samazināt indivīda kognitīvo un kopējo psihologisko funkcionēšanu (Chen \& Kang, 2009). Pastāv saistība starp zemu paškontroles spēju, dzimumu, vecumu un prokrastināciju un biežāk piedzīvotu nepietiekamu miegu. Pētījumi rāda, ka nozìmīga sabiedrības daḷa gul mazāk, nekā vinịi gribētu (Adriaanse et al., 2014). Nỉderlandē veiktajā pētījumā 30\% no respondentu grupas uzrādīja, ka pastāvīgi gul par 7-9 stundām nedēḷā mazāk, nekā nacionālais miega fonds rekomendē vidējam pieaugušajam. Šì paša pētījuma ietvaros 
84\% respondentu atbildēja, ka viṇi guḷ pārāk maz vismaz vienu reizi nedēl̦ā. Problēmu rada tas, ka cilvēks tiek "iesūkts" darbībās, kas tiek darītas vakaros, jo darbības, kuras mēs veicam mūsdienās, ir atkarību izraisošas, kā norāda pētījuma autori. Autori norāda, ka mūsdienu $24 \mathrm{~h} / 7 \mathrm{~d}$ darba kultūra, tehnolog̣ijas un sociālie mediji ir lielākie ierosinātāji gulētiešanas laika novilcināšanai (prokrastinācijai) (Moran, 2015).

Nogurums kopumā tiek definēts kā enerǵijas un motivācijas trūkums, kas var būt gan fizisks, gan garīgs. Nogurums nav tas pats, kas miegainība, tomēr vēlme gulēt var pavadīt nogurumu. Bieži nogurums tiek raksturots ar tādām pazīmēm kā izsmeltība, liels vājums, enerǵijas trūkums, spēka izsīkums (Davish, 2015). Nogurums ietekmē indivīda ikdienas aktivitāti, spēju strādāt, sociālo dzīvi un ikdienas dzīves kvalitāti. Tas tiek saistīts ar pazeminātām kognitīvām spējām un indivīda ikdienas lomām, kā piemēram, attiecībām ar tuviniekiem, sociālo integrāciju. Nogurums var novest pie nopietnākām problēmām, kā depresija, bezmiegs un pašvērtējuma samazināšanās. Kad cilvēks prokrastinē, tad arī vienkāršs uzdevums var pārvērsties par grūti paveicamu. Prokrastinācija un nogurums ir cikls, kur viens pastiprina otru un cilvēks bieži vien neredz reālu progresu savā darbībā (Schraw, Wadkins, \& Olafson, 2007).

Pētijumos ir konstatēta saistība starp lielu darba slodzi, nogurumu pēc darba, prokrastināciju un psiholoğisko atsvešinātību no darba. Liela darba slodze, nogurums, psihologiskā atsvešinātība var novest pie darbu atlikšanas jeb prokrastinēšanas (Armond, Bunk, \& Matthews, 2014). Ir pierādīts, ka arī gulētiešanas laika prokrastinācijai ir saistība ar pašregulāciju un ar kopējo prokrastināciju. Gulētiešanas laika novilcināšanai ir saistība ar nogurumu, jo pieņemt lēmumu doties gulēt ir jāizdara vakarā, kad ir sakrājies nogurums un ir samazināta garīgā enerğija un paškontroles spējas ir vājākas. Liels skaits apkārtējo traucēkḷu var būt iemesls gulētiešanas prokrastinācijas attīstībai (Adriaanse et al., 2014).

Nogurums ir viena no sastopamākajām sūdzībām, kad cilvēki dodas pie ārsta. Veselïbas pētījumos, kur piedalijās aptuveni 17 miljoni par piecdesmit gadiem vecāku cilvēku, $31 \%$ no tiem norādīja, ka jūtas noguruši. Nogurums ir simptoms, nevis slimība un dažādi cilvēki piedzīvo nogurumu atškirīgos veidos. Viena veida nogurumu izjūt pēc garas dienas, laika zonu maiņas vai saistîbā ar kādu saslimšanu. Tomēr pastāv arī tāds nogurums, kuru ierosina stress vai miega trūkums naktī, kas turpina pastāvēt pat pēc ilgstošas atpūtas. Tādēl ir svarīgi noteikt cēloni un iemeslu, kādēl nogurums rodas (saslimšana, stress, slikts uzturs, neizgulēšanās u.c.). Zinātnieki ir definējuši arī specifisku traucējumu, ko sauc par hronisko noguruma sindromu. To izraisa pastāvīgs un ilgstošs nogurums, kā atzīst medicīnas profesors Hārvardā Antonijs Komarovs (Anthony Komaroff), kurš ir eksperts šì sindroma izpētē. Aptuveni 8 pieaugušie no katriem 1000 iedzìvotājiem Amerikas Savienotajās valstīs cieš no hroniskā noguruma sindroma un sievietes to piedzìvo divas reizes vairāk nekā vīrieši. Šì sindroma izraisītāji vēl joprojām nav līdz galam noskaidroti un nav vēl izveidots precīzs diagnostikas tests. Tomēr, zinātnieki ir atraduši nepilnības un izmainas smadzeṇu darbībā un perifērajā nervu sistēmā, imūnsistēmā un enerğijas metabolismā cilvēkiem, kuri cieš no šì sindroma (Allison, 2011).

Daži autori ir izstrādājuši teoriju par noguruma noturību. Viṇu modelī atribūcijas efekts, fizisko aktivitāšu daudzums, izjūta par savu spēju tikt galā, kontrolēt simptomus 
un fokusēšanās uz ķermeniskiem simptomiem spēlē l,oti lielu lomu. Nogurums parasti tiek iedalīts fiziskajos un garīgajos komponentos. Fizisks nogurums ir ķermeniskas sāpes, kas rodas no pārslogotiem muskuliem fiziskās slodzes laikā un simptomi, kuri rodas no apstākḷiem, kā piemēram, fiziskas piepūles bez atpūtas vai miega, kā arī medikamentu lietošanas periodā. Garīgs nogurums samazina psiholoǵisko kapacitāti un rada mazāku vēlmi darboties agrākajā garīgā un fiziskā līmenī. Garīga noguruma sekas var būt pazemināta kompetence un pazemināta vēlme attīstīt un virzìt savus mērḳus. Autori norāda, ka pastāv fundamentāla atškirība starp fizisku un garīgu nogurumu (Heck, Michielsen, Sijtsma,Vries, \& Vijver, 2004).

Teorētiskās nostādnes apstiprina, ka skolotāja profesija saistās ar paaugstinātu stresu, izsīkumu un izdegšanas risku (Aydogan, Dogan, \& Bayram, 2009). Stresa iemesli var būt dažādi, šie aspekti ir saistīti ar ārējo vidi un prasībām, ar kurām skolotāji saskaras, piemēram, darba vidi izglītības iestādē, reformām izglītībā, skolēniem. Viens no skolas darba stresoriem ir virsstundu darbs, jo skolotājs ir iesaistīts ne tikai ikdienas mācību stundu vadīšanā, bet arī audzināšanā un ārpus klases darbā, nereti veicot papildus administratīvos pienākumus. Skolotāju darbs pēc kontaktstundām ir saistīts ar skolēnu darbu labošanu un nākošās dienas stundu sagatavošanu. Stress var rasties arī no skolotāja personīgajiem un iekšējiem faktoriem. Pētījumu rezultāti l̦auj secināt, ka augstāka prokrastinācija skolotājiem ir saistīta ar zemāku patiku pret darbu (Armond, Bunk, \& Matthews, 2014). Šādi skolotāji varētu atlikt darbus un iesaistīties kādās patīkamākās nodarbēs. Lìdz ar to nepadarītie darbi uzkrāsies un pieaugs trauksme, kas rada vispārēju negatīvu nokrāsu cilvēka darba dzīvē un samazinātu patiku pret darbu. Skolotāji, kuri prokrastinē, nereti nav sagatavojušies stundām un piedzīvo neefektivitātes izjūtu. Rezultātā var samazināties darba produktivitāte stundās arī no skolēnu puses (Mohsin \& Ayub, 2014). Cits pētījums rāda, ka vidusskolas skolotāji prokrastinē ikdienā un tas paaugstina stresa līmeni (Wyk, 2004). Diemžēl maz ir pētīta prokrastinācijas saistība ar darba vides faktoriem, jo prokrastinācija pamatā tiek pētīta akadēmiskā kontekstā (kā mācību uzdevumu izpildes atlikšana un novēlošana). Ir pierādīts, ka pastāv pozitīva korelācija starp prokrastināciju un piedzīvoto stresu visās jomās - kognitīvi, emocionāli, fiziski un sociāli. Tātad jo lielāks ir piedzīvotais stress, jo augstāki varētu būt prokrastinācijas rādītāji (Verešova, 2013).

Tā kā skolotāju darba kvalitātes būtiski mainīgie ir nogurums un tendence atlikt veicamos pienākumus, kas var izpausties arī kā gulētiešanas laika novilcināšana, tiek izvirzīti divi pētījuma jautājumi: Kā skolotāju noguruma un prokrastinācijas kā iezīmes rādìtāji prognozē gulētiešanas laika novilcināšanu? Kā virsstundu darbs prognozē gulētiešanas laika novilcināšanu skolotājiem?

\section{Metode}

\section{Pētijjuma dalībnieki}

Pētījuma izlasi veidoja 229 pašreiz strādājoši skolotāji, kuru profesionālā darba pieredze ir vismaz viens gads. Dzimumu sadalījums (26 vīrieši jeb 11\% no kopèjās izlases un 203 sievietes jeb 88\%) ir disproporcionāls, bet tipisks skolotāja profesijā strādājošo dzimumu sadalījumam Latvijā. Vidējais vecums skolotāju izlasē ir 43 gadi $(\mathrm{M}=43,66 ; \mathrm{SD}=11,57)$. 


\section{Instrumentārijs}

Pokrastinācijas aptauja (Procrastination Scale (PS), Lay, 1986). Latvijā aptauju 2011. gadā adaptējusi Renāte Buliṇa. Aptauja novērtē uzvedības prokrastinācijas tendences, ikdienas uzdevumu uzsākšanas novilcināšanu. Tā sastāv no 20 apgalvojumiem, kuri tiek vērtēti Likerta 5 punktu skalā, kur 1 ir "nemaz nav raksturīgi" un 5 ir "loti raksturīgi". Jautājumu piemēri prokrastinācijas aptaujā: "Es bieži vien attopos veicam uzdevumus, ko biju paredzējis paveikt vairākas dienas iepriekš. Es bieži vien palaižu garām koncertus, sporta pasākumus vai līdzīgus notikumus, jo nepamanos laicīgi iegādāties biḷetes. Kad no rìta ir laiks celties, visbiežāk es uzreiz arī izkāpju no gultas. Pēc neatbildētiem zvaniem es parasti pārzvanu pie pirmās iespējas. Parasti es lēmumus pieņemu, cik ātri vien iespējams." Augstāks iegūto punktu skaits norāda uz lielāku respondenta tendenci novilcināt uzdevuma uzsākšanu ikdienā.

Gulètiešanas laika prokrastinācijas skala (Bedtime procrastination scale, Adriaanse, De Ridder, Evers, \& Kroese, 2014). Aptauju sastāda 9 jautājumi, kur atbildes tiek sniegtas Likerta skalā no 1 (nekad) līdz 5 (vienmēr). Aptauju adaptējusi Ginta Slišāne 2016. gadā. Jautājumu piemēri gulētiešanas laika prokrastinācijas skalā: "Es eju gulēt vēlāk nekā es biju plānojis/usi. Ja ir laiks izslēgt gaismas, tad es to daru nekavējoties. Bieži es daru citus darbus tad, kad ir laiks iet gulēt. Es regulāri eju gulēt noliktajā laikā." Augstāks iegūto punktu skaits norāda uz lielāku tendenci novilcināt gulētiešanu.

Noguruma aptauja (The Fatigue Scale, Chalder et al., 1993) ietver jautājumus par nogurumu, kur atbildes ir jāsniedz Likerta skalā atbilstoši 1 (nekad) līdz 5 (vienmēr). Aptauju adaptējusi Ginta Slišāne 2016. gadā. Jautājumu piemēri noguruma aptaujā, kur atbilde jāsniedz likerta skalā: "Nogurums man traucē. Es l̦oti ātri nogurstu. Man ir pietiekoši enerǵijas ikdienas darbiem. Fiziski es jūtos iztukšots. Man nav vēlēšanās kaut ko darīt. Kad es kaut ko daru, tad varu koncentrēties diezgan labi." Lielāks iegūto punktu skaits norāda uz augstāku nogutuma lìmeni.

Demogrāfiskā aptauja. Tika uzdoti jautājumi par dzimumu, vecumu, gimenes stāvokli, darba pieredzi, darba slodzi nedēḷā, virsstundām. Tà kā pētijumā viens no mainīgajiem ir virsstundas, tad aptaujas demogrāfiskajā dą̧ā tika uzdots jautājums: "Cik daudz virsstundas Jūs strādājat? (gatavojoties stundām, labojot mājasdarbus, kontroldarbus)". Pieejamie atbilžu varianti bija: "Nestrādāju virsstundas. Līdz 5 stundām

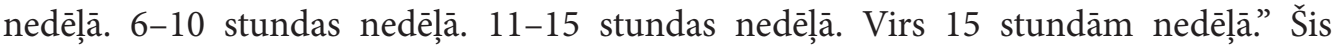
mainīgais sniedz priekšstatu par to, cik daudz stundas skolotāji ikdienā strādā papildus, kā arī novērtēt saistību ar šì pētījuma mainīgajiem. Jāuzsver, ka netika pētìts reālais nostrādāto virsstundu skaits, bet gan skolotāja pašnovērtējums par to, cik daudz viņš strādā ārpus sava darba laika.

\section{Procedūra}

Aptaujas tika apvienotas vienā failā un augšupielādētas google.doc sistēmā. Tika izsūtìts e-pasts 83 galvaspilsētas Rīgas un četrām pierīgas vispārizglìtojošām skolām, ar lūgumu aptaujas izsūtīt konkrētās skolas skolotājiem. No saņemtajām 236 anketām pēc pārbaudes no turpmākās datu analīzes tika izslēgtas septiņas anketas, kuras neatbilda pētijuma prasībām, jo bija izpildītas nepilnīgi. Iegūtie dati tika apkopoti Excell failā, pārnesti uz SPSS sistēmu, kodēti un apstrādāti. 


\section{Rezultāti}

Pirms atbildēt uz izvirzìtajiem pētỉjuma jautājumiem, tika aprēḳināti aptauju aprakstošās statistikas rādītāji (skat. 1. tabulu) un pārbaudìta visu trīs aptauju ticamība, aprēḳinot vienu no metodes iekšējās saskaņotības rādītājiem Kronbaha alfa koeficientu (skat. 1. tabulu).

1. tabula. Aprakstošās statistikas rādītāji kopējai skolotāju izlasei un aptauju ticamības rādītāji (Kronbaha alfa koeficients $(\mathrm{N}=229)$ )

\begin{tabular}{lccc}
\hline & $M$ & $S D$ & $\alpha$ \\
\hline Gulētiešanas laika novilcināšana & 3,13 & 0,04 & 0,87 \\
Nogurums & 2,30 & 0,05 & 0,84 \\
Prokrastinācija & 2,58 & 0,15 & 0,82 \\
\hline
\end{tabular}

Rezultāti norāda, ka gulētiešanas laika novilcināšanas, noguruma un prokrastinācijas aptauju ticamība ir laba, līdz ar to aptaujas ir ticamas un rezultāti interpretējami. Lai atbildētu uz izvirzītajiem pētījuma jautājumiem, kā skolotāju noguruma un prokrastinācijas kā iezīmes rādītāji prognozē gulētiešanas laika novilcināšanu un kā virsstundu darbs prognozē gulētiešanas laika novilcināšanu skolotājiem, tika lietota soḷu regresiju analīze. Izveidotais modelis ir statistiski nozīmīgs (skat. 2. tabulu).

2. tabula. Soḷu lineārās regresijas analīzes rezultāti atkarīgajam mainīgajam gulētiešanas laika novilcināšana $(\mathrm{N}=229)$

\begin{tabular}{lccccc}
\hline \multicolumn{1}{c}{ Neatkarīgais mainīgais } & $B$ & $S E B$ & $\beta$ & $F$ & $R^{2}$ \\
\hline 1. solis & & & & & \\
Prokrastinācija & 0,53 & 0,09 & $0,36^{*}$ & $32,94^{*}$ & 0,13 \\
\hline 2. solis & & & & & \\
Prokrastinācija & 0,53 & 0,09 & $0,36^{*}$ & & \\
Virsstundas & 0,14 & 0,43 & $0,19^{*}$ & $22,12^{*}$ & 0,16 \\
\hline
\end{tabular}

${ }^{*} p<0,05$

Rezultāti parāda, ka skolotāju prokrastinācija kā iezīme statistiski nozīmīgi prognozē $13 \%$ no gulētiešanas laika novilcināšanas $\left(\mathrm{F}=32,94, \mathrm{p}<0,05, \mathrm{R}^{2}=0,13\right)$. Prokrastinācija kopā ar virsstundām prognozēto variāciju palielina par 3\%, un kopā abi mainīgie izskaidro $16 \%$ no kopējās gulētiešanas laika novilcināšanas $(\mathrm{F}=22,12, \mathrm{p}<0,05$, $\left.\mathrm{R}^{2}=0,16\right)$. Nogurums netika iekḷauts regresijas modelī, jo korelācija ar gulētiešanas laika novilcināšanu šim mainīgajam nebija statistiski nozīmīga.

Pētijuma rezultāti parāda, ka prokrastinācija kā iezīme pati par sevi, gan kopā ar lielāku nostrādāto virsstundu skaitu prognozē gulētiešanas laika novilcināšanu skolotājiem. Savukārt nostrādātās virsstundas nav saistītas ar lielāku nogurumu, līdz ar to nogurums neprognozē gulētiešanas laika novilcināšanu skolotājiem. 


\section{Diskusija}

Pētījuma rezultāti kopumā parāda, ka skolotāju prokrastinācija kā personības iezīme un papildus nostrādāto virsstundu skaits statistiski nozīmīgi prognozē gulētiešanas laika novilcināšanu. Skolotājiem ar vairāk izteiktu prokrastināciju kā personības iezīmi un lielāku pašnovērtēto virsstundu darbu ir lielāka tendence atlikt gulētiešanas laiku. No tā var secināt, ka prokrastinācija un virsstundu strādāšana darbā noved pie tā, ka skolotājs novilcina gulētiešanu. Šis secinājums sasaucas ar citos pētījumos gūtajām atzin̄ām, ka prokrastinācija ir saistīta ar gulētiešanas laika novilcināšanu (Adriaanse et al., 2014; Armond, Bunk, \& Matthews, 2014).

Nozīmīgi ir tas, ka šajā pētījumā atklājas sakarība, ka prokrastinācija un skolotāja norādītās virsstundas prognozē gulētiešanas laika novilcināšanu, nevis kā teorijā aprakstīts, ka prokrastinācija un nogurums ir saistīti (Schraw, Wadkins, \& Olafson, 2007; Deardorff, 2010). Atbildot uz pētījuma jautājumu, tika konstatēts, ka pētāmajā grupā skolotāju vispārējais nogurums neprognozēja gulētiešanas laika novilcināšanu. Minēto pretrunu varētu izskaidrot, ka prokrastinācija šajā pētijumā tiek aplūkota kā personības iezīme, nevis situatīva reakcija. No vienas puses skolotāja darbā varētu būt grūti novilkt pienākumu veikšanas robežas tikai formālajā darba laikā un skolotāji patiešām varētu strādāt virsstundas, lai paveiktu visus savus pienākumus. No otras puses, skolotāja nepieciešamība strādāt virsstundas varētu izrietēt arī no tā, ka skolotājs prokrastinē ikdienā pamatdarba laikā un ir nepieciešams strādāt līdz vēlam vakaram, jo darbi pa dienu ir atlikti un šāda veida virsstundas ir vienīgā izeja darbu izpildē. Iespējams arī, ka skolotāji par virsstundām uzskata ko citu, piemēram, pēc kontaktstundām veicamos pienākumus savā darba laikā, līdz ar to tās nesaistās ar nogurumu. Iespējams, ka Latvijas pedagogiem atškiras izpratne par virsstundu darbu no citu valstu respondentiem, kur tiek veikta lielākā dalıa no publicētajiem pētījumiem.

Šì pētījuma galvenie secinājumi ir 1) prokrastinācija kā iezīme gan pati par sevi, gan kopā ar paša skolotāja vērtējumā lielāku nostrādāto virsstundu skaitu prognozē gulētiešanas laika novilcināšanu skolotājiem; 2) nostrādātās virsstundas nav saistītas ar lielāku nogurumu, līdz ar to nogurums neprognozē gulētiešanas laika novilcināšanu skolotājiem.

Šie secinājumi varētu būt nozīmīgi pedagogiem, n̦emot vērā, ka darbu atlikšana ikdienā un papildus virsstundas veicina gulētiešanas laika novilcināšanu, kas var samazināt darba kvalitāti nākamajā dienā. Pētījuma rezultāti sasaucas ar citu pētnieku atziņām, ka skolotāju prokrastinācija ir saistìta ar darba stresu, savukārt darba stress ir saistīts ar apmierinātîbu ar darbu (Mohsin \& Ayub, 2014). Lìdz ar to pedagogam būtu nozīmīgi apzināti kontrolēt tendenci atlikt savlaicīgu pienākumu veikšanu ikdienā, rēķinoties, ka tā var nest līdzi ilgtermiņa sekas.

Pētijuma stiprās puses ir pietiekoši liela izlase, atbilstoši izvēelētas aptaujas, fokusējoties uz katru pētāmo mainīgo. Zinātniskais pienesums ir divu metožu adaptācija. Pētījumam ir arī vairāki ierobežojumi. Pirmkārt, informācija par piedalǐšanos pētỉjumā skolotājiem tika nodota caur skolas vadību, kam tika nosūtìtas informatīvas vēstules. Otrkārt, termina virsstundas saturs būtu jāprecizē. Šì pētījuma rezultātus varēja iespaidot pedagogu atškirīịā izpratne par to, kas ir virsstundas. 


\section{Izmantotā literatūra}

Adriaanse, M. A., Evers, C., Kroese, F. M., Marieke, A., \& Ridder, D. (2014).

Bedtime procrastination: A self-regulation perspective on sleep insufficiency in the general population. Journal of Health Psychology, 1-10, DOI: 10.1177/1359105314540014

Adriaanse, M. A., De Ridder, D. T. D., Evers, C., \& Kroese, F. M. (2014). Bedtime procrastination: introducing a new area of procrastination. Front. Psychol. 5:611. doi: 10.3389/fpsyg.2014.00611.

Allison K. C. (2011). Fight fatigue by finding the cause. POSTED JULY 06, 2011, 11:47 AM UPDATED SEPTEMBER 29, 2011. http://www.health.harvard.edu/blog/fightfatigue-byfinding-the-cause-201107062952.

Armond, S., Bunk, J., \& Matthews, R. (2014). Workload and procrastination: The roles of psychological detachment and fatigue. International Journal of Stress Management, 21, No. 2, 137-161.

Ariely, D., \& Wertenbroch, K. (2002). Procrastination, deadlines, and performance: Selfcontrol by precommitment. Psychological Science, 13(3), 219-224.

Aydogan, I., Dogan, A. A., \& Bayram, N. (2009). Burnout among Turkish high school teachers working in Turkey and abroad: A comparative study. Electronic Journal of Research in Educational Psychology, 7, 1249-1268.

Buxton, O. M., \& Marcelli, E. (2010). Short and long sleep are positively associated with obesity, diabetes, hypertension, and cardiovascular dis- ease among adults in the United States. Social Science \& Medicine 71, 1027-1036.

Chen, S. C., \& Kang, J. H. (2009). Effects of an irregular bedtime schedule on sleep quality, daytime sleepiness, and fatigue among university students in Taiwan. BMC Public Health, 9: 248.

Davish, C. P. (2015). Fatigue. http://www.emedicinehealth.com/fatigue/article_em.htm.

Deardorff, J. (2010). Exhaustion: Why feeling really tired can threaten your health. Experts say exhaustion is a valid medical condition. October 16, 2010. http://articles.chicagotribune. com/2010-10-16/health/ct-met-muti-exhaustion-20101016_1_van-cauter-chronic-stressside-effect.

Harriott, J., \& Ferrari, J. R. (1996). Prevalence of procrastination among samples of adults. Psychological Reports, 78, 611-616.

Heck, G., Michielsen, H. J., Sijtsma, K., Vries, J., \& Vijver, F. (2004). Examination of the Dimensionality of Fatigue. The Construction of the Fatigue Assessment Scale (FAS). European Journal of Psychological Assessment, 20, 1, 39-48.

Krause, K., \& Freund, A. M. (2014). How to Beat Procrastination. The Role of Goal Focus. European Psychologist, 19(2), 132-144.

Kroese, F. M., de Ridder D. T. D., Evers C., et al. (2014) Bedtime procrastination: Introducing a new area of procrastination. Frontiers in Psychology, 5, 611.

Mohsin, F. Z., \& Ayub, N. (2014). The relationship between procrastination, delay of gratification, and job satisfaction among high school teachers. Japanese Psychological Research, doi: 10.1111/ jpr.12046 2014, 56, No. 3, 224-234.

Moran, G. (2015). How to break your sleep procrastination habit. February 23, 2015. http:/ www.fastcompany.com/3042679/sleep-week/how-to-break-your-sleepprocrastination habit National Sleep Foundation. (2005). Sleep in America Poll. Washington, DC: National Sleep Foundation. 
O'Brien, W. K. (2002). Applying the transtheoretical model to academic procrastination. Unpublished doctoral dissertation, University of Houston.

Pietrzak, A., \& Tokarz, A. (2016). Procrastination as a form of misregulation in the context of affect and self-regulation. Studia Humana, 5, 3, 70-82. DOI: 10.1515/sh-2016-0016.

Ram S., Seirawan H., Kumar S. K., et al. (2010) Prevalence and impact of sleep disorders and sleep habits in the United States. Sleep and Breathing, 14, 63-70.

Rubene, K. (2013). Biznesa vārdnīca-prokrastinācija. 26.09.2013. http://www.monday.lv/ biznesa-vardnica-prokrastinacija/.

Saracaloglu, A. S., \& Gokdas, I. (2016). Variables that predict academic procrastination behavior in prospective primary school teachers. Journal of Educational Sciences Research, 6, 1, 43-56. http://dx.doi.org/10.12973/jesr.2016.61.3.

Schraw, G., Wadkins, T., \& Olafson, L. (2007). Doing the things we do: A grounded theory of procrastination. Journal of Educational Psychology, 99, 12-25. doi: 10.1037/0022-0663.99.1.12.

Schouwenburg, H. C., \& Groenewoud, J. T. (2001). Study motivation under social temptation: Effects of trait procrastination. Personality and Individual Differences, 30, 229-240. doi: 10.1016/S0191-8869(00)00034-9.

Steel P. (2007). The Nature of procrastination: A Meta-Analytic and thoretical review of quintessential self-regulatory failure. Psychological Bulletin, 133, No. 1, 65-94.

Steel, P., Brothen, T., \& Wambach, C. (2001). Procrastination and personality, performance, and mood. Personality and Individual Differences, 30, 95-106.

Sires F. M. (2014). Procrastination and stress: Exploring the role of self-compassion, Self and Identity, 13, No. 2, 128-145.

Tice, D. M., \& Baumeister, R. F. (1997). Longitudinal study of procrastination, performance, stress and health: The costs and benefits of dawdling. Psychological Science, 8, 454-458.

Verešova, M. (2013). Procrastination, stress and coping among primary school teachers. Procedia - Social and Behavioral Sciences, 106 (2013) 2131-2138.

Wolters, C. A. (2003). Understanding procrastination from a self-regulated learning perspective. Journal of Educational Psychology, 95, 179-187. doi: 10.1037//0022-0663.95.1.179.

Wyk, L. V. (2004). The relationship between procrastination and stress in the life of the high school teacher. (Unpublished doctoral dissertation). University of Pretoria, Pretoria, South Africa. 


\title{
Personality traits, perceived social support and self-efficacy in people with and without chronic disease
}

\author{
Melne Ieva and Gaitniece-Putāne Anda ${ }^{1}$
}

University of Latvia

\begin{abstract}
The goal of this study was to examine the differences in personality trait ratings, perceived social support and self-efficacy between people with and without chronic disease. Also examined were the associations between personality trait ratings, perceived social support and self-efficacy for people with and without chronic disease.

Participants of the study were 50 persons suffering from chronic disease, and 50 persons not suffering from chronic disease, all of whom were aged between 18 and 50 years. The study results showed differences between both groups in ratings of self-efficacy and perceived social support from friends. Respondents without chronic disease report higher ratings on self-efficacy than those with chronic disease. Ratings of self-efficacy were associated with the personality traits of openness and conscientiousness (positively) and neurotism (negatively) in both groups. For respondents suffering from chronic disease the personality trait extraversion was associated with perceived social support from friends.
\end{abstract}

Keywords: personality traits, perceived social support, self-efficacy, chronic disease

\section{Chronic disease}

Chronic disease is a long-term illness or a group of long-term persistent symptoms which last for three or more months. The treatment of chronic disease often includes long-term use of medication and the involvement of various specialists (Hoffman \& Rice, 1996; O’Halloran, Blackstock, Shields, Holland, Iles Kingsley, Bernhardt, Lannin, Morris, \& Taylor, 2014).

Chronic diseases differ on a spectrum from lighter symptoms with which patients manage to live fairly well on a daily basis, up to heavy and difficult to bear symptoms or diseases which hamper daily living, and often are interacting with other illnesses. Persons who are suffering from any of the forms of chronic disease often have to face issues not only in regard to somatic medicine, but also mental health issues. Chronic disease involves physiological, psychological and social change (Penley, Tomaka, \& Wiebe, 2002; Sharpe \& Curran, 2006), and some chronic diseases have been considered to be life challenges (Go et al., 2013). Chronic diseases can cause different kinds of disability, functional problems and in the long therm - chronic disease can cause premature death (McCathie, Spence, \& Tate, 2002; Strong, Mathers, Leeder, \& Beaglehole, 2005; Evers, Zautra, \& Thieme, 2011). In addition, chronic disease can affect personality traits, and

1 Corresponding author: Anda Gaitniece-Putāne, University of Latvia, Jurmalas gatve 76, Riga LV-1083, Latvia. Email: anda.gaitniece@lu.lv 
sometimes the physiological effects of the disease may become a diagnostic aspect of a personality disorder (Jokela, Hakulinen, Singh-Manoux, \& Kivimäki, 2014).

Chronic disease affects not only the person who is ill, but also the person's loved ones, such as family and friends (Brannon \& Feist, 2000). This means that a chronic disease can affect the individual's social life, family and work (Vilhena, Pais-Ribeiro Silva, Pedro, Meneses, Cardoso, da Silva, Mendonca, 2014).

\section{Chronic pain}

One of the most frequently occurring chronic disease symptoms or side effects is chronic pain. Chronic pain can be caused by damage to the peripheral or central nervous system as a result of the disease or trauma. Chronic pain is a commonly encountered problem within society at large. According to the National Academies of Science Institute in 2011 about 116 million adult USA citizens reported that have experienced chronic pain. In another study of 5336 Dutch children and adolescents, aged 4 to 18 years, about $25 \%$ of them have been experienced chronic pain (Perquin, Hazebroek-Kampschreur, Hunfeld, Bohnen, van Suijlekom-Smit, Passchier \& van der Wouden, 2000; Jensen \& Turk, 2014). Other studies have reported that about $10 \%$ of the world's population suffers from chronic pain (Jackson, Stabile, \& McQueen, 2014).

Chronic pain has a significant impact on human health, quality of life, mood, physical and psychological state of being. Patients with chronic pain most often experience low mood, have difficulty in performing actions, have increased fatigue and negative cognitions (Karoly \& Ruehlman, 2006; Nicholas. Linton, Watson, \& Main, 2011; Newton-John, Mason, \& Hunter, 2014 ); increased use of medication, psychological distress (Kernsm, Sellinger, \& Goodine, 2011; Newton-John, Mason, \& Hunter, 2014); adverse effects on psychosocial functioning, lack of resilience, and lack of adaptation leading to a state of negative well-being (Newton-John, Mason, \& Hunter, 2014). The scientific literature reports that the long-term ability to adapt is associated with a person's ability to change their behavior and cognitions in order to more positively perceive the painful experience and its consequences (Loeser \& Turk, 2003; Novy, Nelson, Francis, \& Turk, 1995; Kratz, Molton, Jensen Ehde, \& Nielson, 2011).

Jessen and colleagues (Jessen, Nielson, \& Kern, 2003) have presented the Motivation Model of Pain Management, whereby the patient's degree of motivation plays an important role in influencing whether he or she will be able to adapt to the particular health situation. This model is focused on the patient's readiness to change, including the patient's own perception of how important (for the patient) it is to change one's behaviour, and the patient's own perceived ability to adapt, or the ability to use adaptive techniques which are associated with the patient's self-efficacy. Adaptation and coping involves constant cognitive and behavioral change in order to be able to manage the external or internal needs of the situation (Lazarus \& Folkman, 1984; Banerjee, Bhattacharya, \& Sanyal, 2014). Coping with a stressful situation may include rest, adherence to the required medication, relaxation, professional help from experts, discussions with friends, searching for information, using problem-solving strategies, etc. (Banerjee, Bhattacharya, \& Sanyal, 2014). Chronic pain can be a co-disease which accentuates a primary illness. 
Various theoretical and practical models have been used in order to understand and provide help for chronic pain patients, including the Biopsychosocial Model of Disease (Gatchel \& Turk, 1996; Engel, 1980), which identifies biological, psychological and social risk factors and protective factors. Other models include the Operant Model (Fordyce, Fowler, \& DeLateur, 1968; Fordyce, Lehmann, Delateur, Sand \& Trieschmann, 1973), which is based on changing behavior with the use of behavioral therapy. The Peripheral Physiological Model provides psychological relaxation training and biofeedback, thereby allowing the patient to understand his or her own body signals in relation to the chronic pain. The Cognitive Coping Model (Keefe \& Bradley, 1984; Turk, Meichenbaum, \& Genest, 1983; Turner, 1982) is focused on changing cognitions. The central nervous system Neurophysiological Model explains how psychological difficulties are affecting one's physiological well-being (Melzack \& Wall, 1965).

One of the main psychological pain management models is the Operant Model, based on the hypothesis that human behavior, regardless of whether or not the patient has chronic pain, is sensitive and responsive to the environment in which the patient is living (Fordyce et al., 1968). Operant chronic pain management begins with an analysis of the patient's behavior in order to identify the environmental factors which contribute to and maintain these behaviors. Later the focus is on life goals and improvement of general functioning, rather than the consequences of pain. This model consists of psychotherapy, physical exercise, relaxation exercises and self-realization training (Jensen \& Turk, 2014).

\section{Personality traits}

The presence of chronic disease in the human body can affect significant changes in the patient's personality, changes in the perception of events, and changes in behavior and cognitive processes (Belgrave \& Washington, 1986). There are many forms of how people percieve health, ways of treatment and illness symptom management. Aspects of understanding the above are highly dependent on human personality traits which can affect health oucomes (Aldwin, Spiro, Levenson, \& Cupertino, 2001). People who suffer from chronic disease often experience significant changes in their professional, social and family life. These changes can be episodic, unpredictable, and they can contribute to the patient's stress level and affect the patient's level of self-confidence (Belgrave \& Washington, 1986).

The long-term presence of the disease can affect changes in a person's personality, and, in turn, personality traits may affect a person's behavior and willingness to engage in actions to improve their lives, and to improve the state of their health (Barger, 2006; Benyamin, Idler, Leventhal, \& Leventhal, 2000; Chapman, Duberstein, \& Lyness, 2007; Jerant, Chapman, \& Frank, 2008).

According to the Five Factor Model personality can be described according to five broad personality traits: neurotism - measured as emotional stability or instability, stress reactions; extraversion - refers to interpersonal interaction, energetic behavior; openness - openess to new experiences, new ideas, aesthetic and intellectual feelings; agreeableness - the quality of relationship, trust, altruism and friendliness; and conscientiousness - motivated and purposeful behavior, tendency to be goal-oriented, diligence 
(Jerant, Chapman, \& Frank, 2008; Costa \& McCrae, 1992). The Five Factor Model of personality plays an important role not only in the field of psychology, but also in the field of medicine. It implies that the state of human health depends not only on physiological factors, but also psychological factors (Jerant et al., 2008).

Bogg and Roberts (Bogg \& Roberts, 2004) have shown that high conscientiousness is related to health promotion, for example, those with high conscientiousness are more apt to be engaging in sports or maintaining a healthy diet, while low conscientiousness is related to health deterioration behavior - for example consumption of alcohol or high speed driving. Another study found that low conscientiousness and high neurotism was associated with smoking behavior (Terraciano \& Costa, 2004). Those patients who indicated high neurotism and low conscientiousness were at most risk of having difficulties in successfully coping with the symptoms of their disease, and having difficulties in being motivated to engage in health improvement and taking their medication (Christensen \& Smith, 1995; Deary, Weiss, \& Batty, 2010). Personality traits are associated with the way in which people cope with adverse health, their psychological well-being, behavior, their attitude towards their health, socioeconomic status, social support and self-efficacy (Deary et al., 2010).

In turn, self-efficacy and perceived social support have been put forward as mediators between personality traits and well-being (Ebstrup, Eplov, Pisinger, \& Jorgensen, 2011; Strobel, Tumasjan, Sporrle, 2010; Axelsson, Lotvall, Cliffordson, Lundgren \& Brink , 2013). Studies also have indicated associations between personality traits, perceived social support and self-efficacy (Deary, Weiss \& Batty, 2010).

In a number of studies with chronic disease patients, using the Five Factor Model, it has been shown that there is a relationship between higher neurotism and lower conscientiousness, lower agreeableness and lower extraversion (Frank, Chapman, Duberstein, \& Jerant, 2009; Axelsson et al., 2013; Jerant , Chapman, Duberstein, \& Frank, 2010). Another study showed a link between higher neurotism and lower openness and lower agreeableness for people who had experienced physical symptoms and rapid mood changes, and generally were worried about their health (HudekKnezevic \& Kardum, 2009).

The personality traits profile for chronically ill patients most often consists of high levels of neurotism and, depending on the disease and type of symptoms, lower levels of conscientiousness, agreeableness, extraversion, and/or openness. In general it is important to know what are the symptoms of the disease, and how long the person has been suffering from the specific chronic disease (Chapman, Lyness, \& Duberstein, 2007; Deary, Batty, \& Weiss, 2010). The Five Factor Model provides an opportunity to predict and describe personality traits of patients who are ill (Smith \&Williams, 1992; Axelsson et al., 2013).

\section{Perceived social support}

Social support has an important impact on health behaviours (Uchino, 2006). Social support can be seen as providing motivation or encouragement for chronically ill patients to initiate better health behaviours, for example - regular use of medication, timely medical attendance (Fuertes, Mislowack, Bennett, Paul, Gilbert, Fontan, \& 
Boylan, 2007), the use of a healthy diet, exercising (Emmons, Barbee, Gutheil, Stryker, \& Stoddard, 2007) and psychological well-being improvement.

Social support can take the form of informative support, emotional support and/ or instrumental support (McClelland \& McCubbin, 2008). Informative support includes advice, recommendations, and problem solving techniques; emotional support includes assistance in times of stress and difficulty, increasing self-esteem and motivation; and instrumental support includes physical or tactile support, such as specific forms of physical assistance (Cutrona \& Russell, 1990; Warwick, Joseph Cordl, \& Ashworth, 2004).

The following dimensions of social support have been highlighted: received and perceived social support (Barrera, 1986; McClelland \& McCubbin, 2008). Received social support includes both actual physical and spiritual support which helps people to become more motivated, and to adapt more easily within various stressful situations (Nurullah, 2012). In contrast, percieved social support is a more subjective, relative concept and includes the person's perception of the understanding and sympathy which is received from others (Cobb, 1978; de la Iglesia, Stover, Liporace, 2014). The perception of social support is a cognitive, subjective evaluation which enables a person to feel confident that he or she can rely on the help of others (Barrera, 1986; de la Iglesia et al., 2014).

Studies have shown that social support as a whole helps to reduce anxiety and stress, as well as stressful interactions. Other studies have shown that specific types of social support are helpful for specific stress reduction strategies (Olstad, Sexton, \& Søgaard, in 2001; McClelland \& McCubbin, 2008), and sufficient quantities of social support can reduce the effect of stress (Kinicki \& McKee, 1996; McClelland \& McCubbin, 2008). In addition, social support can improve a person's mental health in general (LaRocco, House, \& French, 1980; McClelland \& McCubbin, 2008). Evaluation of social support according to gender has shown that women are looking for social support more often than are men (Stokes \& Wilson, 1984; McClelland \& McCubbin, 2008). It is often easier for women to recieve social support because they are more likely to be trusting of others, while men strive to experience themselves as more autonomous, and therefore find it more difficult to trust others (Barbea, Cunningham, Winstead, Derlega, Gulley, \& Yankeelov, 1993; McClelland \& McCubbin, 2008). Thus women are more likely to receive the social support which they need (Belle, 1987; McClelland \& McCubbin, 2008), and they have a greater awareness of the social support which they recieve (Sarason, Sarason, Hacker, \& Basham, 1985; McClelland \& McCubbin, 2008). In general, men and women react differently to different types of social support (Nestmann \& Schmerl, 1991; McClelland \& McCubbin, 2008). Men tend to be more accepting of informative support because of their need for autonomy, while women tend to appreciate not only informative, but also emotional and instrumental support.

\section{Self-efficacy}

Self-efficacy is a powerful psychological tool which is able to influence human behavior in a variety of contexts. Self-efficacy is one's belief in one's ability to organize and execute specific actions or react in specific ways in order to achieve one's goals (Bandura, 1977; Kaul, 2010). Self-efficacy reflects the person's belief that he or she is able 
to organize and integrate the management of emotions, physical and social behaviors in order to be able to find solutions to everyday problems (Lorig, Stewart Ritter, Gonzalez, Laurent, \& Lynch, 1996; Yoo, Kim , Jang \& You, 2011). Also, studies have shown that high levels of self-efficacy contribute to the improvement of one's health, positive selfevaluation and management of appropriate behaviors (Weng, Dai Huang, Chiang, 2010; Yoo, Kim, Jang, \& You, 2011).

Low levels of self-efficacy among chronic disease patients contribute to the development of depression and anxiety, as well as the emergence of feelings of helplessness (Schwarzer \& Hall, 2008; Attree, Arroll, Dancey, Griffith, Bansal, 2014). Lowered self-efficacy reduces a person's ability and willingness to achieve one's life goals and reduces the quality of life. People who are faced with low self-efficacy often tend to use emotion-based or passive problem solving strategies. They often rely more on others than on themselves because they struggle to manage their own stress and ability to control the situation (Kristofferzon, Lindqvist, \& Nilsson, 2011).

\section{Personality trait, perceived social support and self-efficacy associations}

Each person's personality traits are different. A longitudinal study carried out by Costa and McCrae in collaboration with Sanderman and Ranchor showed that personality traits tend to persist from childhood to adulthood, specifically, from the ages of 6 to 30 (Costa \& McCrae, 1994). However, these traits - neurotism, extraversion, conscientiousness, openness and agreeableness - become more stable in adulthood (McCrae \& Costa 2003; Roberts \& DelVecchio, 2000; Roberts, Walton, \& Viechtbauer 2006; Deary, Batty, \& Weiss, 2010). These traits refer not only to one's personality, but also to one's possible reactions in different situations.

Personality traits, beliefs and understanding, as well as environmental factors physical and social - are related and have an impact on the person's future actions and behavior, especially in difficult life situations, including situations of health deterioration (Gallant, 2003).

Frequently perceived social support encourages people to become more active, and to get involved in improving their health (Cwikel, Dielman, Kirsch, \& Israel, 1988; Wallston, Alagna, DeVellis, \& DeVellis, 1983; Choi, Chung Park, 2013). The involvement of family members or friends in everyday life promotes the patient's quality of life. Different forms of physical assistance, emotional support, advice or making recommendations from colleagues or treating physicians contribute to a more positive recovery. Specific support services such as food preparation, transportation to the health examinations, spending time together or supportive conversations improve the patient's psychological well-being (Aalto, Uutela, \& Aro, 1997; Gallant, 2003).

Self-efficacy improves the way in which a patient can achieve their goal. If a person has high self-efficacy level, this indicates that he or she has the ability to manage situations and to act effectively for health benefit - to be motivated, to look for opportunities, to improve one's well-being, and to use medication regularly. If this is so, then in the case of chronic illness self-efficacy can improve both physical and psychological well-being (Clark, Becker Janz, Loring, Rakowski, \& Anderson, 1991; Fisher, Arfken, Heins, Houston, Jeff, \& Sykes, 1997; Gallant, 2003). In examining the 
relationship of neurotism and self-efficacy it has been established that neurotism is negatively related to self-efficacy (Williams, O’Brien, \& Colder, 2004).

Studies indicate good results for using intervention techniques to strengthen selfefficacy (Frank et al., 2009). For people who were at high levels of neuroticism and low conscientiousness, low extraversion and low agreeableness, after they started to improve their state of physical health, their psychological well-being improved as well. It was found that persons with a higher self-efficacy were more responsible and complied with the medical requirements, for example, adhered to medication frequency or attended the necessary classes (Bandura, 1997; Axelsson et al., 2013). Studies have shown that there is a relationship between social support and self-efficacy (Levy, 1983; Kaplan \& Hartwell, 1987; Schafer, McCaul, \& Glasgow, 1986; Gallant, 2003). Personality traits affect a person's self-efficacy, sense of responsibility and perception of their quality of life. Conscientiousness has a positive effect on one's sense of responsibility, but neurotism has a negative effect (Axelsson et al., 2013).

Self-efficacy encourages people to achieve their desired goals. It is very important that the patients during their illness can be able to change and improve their attitude towards health issues (Aljasem, Peyre, Wissow, \& Rubin , 2001; DiClemente, Prochaska \& Gibertini, 1985; Holloway \& Watson, 2002; Litt, 1988; Marks \& Allegrante Lorig, 2005; Frank, Chapman, Duberstein, \& Jerant, 2009).

Ebstrup and colleagues (Ebstrup, Eplov, Pisinger, \& Jorgensen, 2011) have shown that self-efficacy may serve as a mediator between personality traits and well-being (Strobel, Tumasjan, \& Sporrle, 2010; Axelsson, Lotvall, Cliffordson, Lundgren, \& Brink, 2013). Numerous other studies have indicated the importance of self-efficacy, personality traits and social support with respect to chronic disease patients (Choi, Chung, \& Park, 2013). By promoting the positive effects of social support and selfefficacy, patients are able to better understand that their health condition can improve, and that this can reflect on their life in the future.

Personality traits affect a person's level of self-efficacy (Deary et al., 2010), and also social support affects self-efficacy, which, in turn, can help to increase or decrease specific aspects of individual personality traits (Gallant, 2003). This indicates that the interrelationship of personality traits, social support and self-efficacy is important for people with and without chronic disease.

Since chronically ill people in their daily life have to experience long-term stress and, as previously mentioned, that the presence of chronic disease in the human body can affect significant changes in the patient's personality (Belgrave \& Washington, 1986), then it can be proposed that in this group of people social support may be especially important in order to improve self-efficacy. Furthermore, higher self-efficacy may effect one's personality traits in more positive position.

In light of previous research findings, the following research questions were posed:

Is there a difference in personality trait ratings, perceived social support and selfefficacy as reported by people with and without chronic diseases?

and

What are the associations between personality traits, perceived social support and self-efficacy for people with and without chronic disease? 


\section{Method}

\section{Study participants}

The sample consisted of 100 respondents, ages 18 to 50 years, of which 50 persons ( 25 men and 25 women) were suffering from chronic disease, and 50 persons ( 25 men and 25 women) were without chronic disease. Respondents' average age is 31 years $(\mathrm{SD}=9.5)$. Initially formed was the group of people with chronic disease, and only after that was formed the control group of people without chronic diseases (matched according to age, education and monthly income, see. Appendix 1). Members of the control group provided information about their state of health (that they were not suffering from health problems) in order to included as appropriate participants of the control group.

There was no significant difference between the mean age of participants in each group. Those in the chronic disease group reported information about their diagnosis and when the diagnosis had been made, see Appendix 2. To participate in this study the illness had to be diagnosed not less than one year previously. Some of the respondents indicated that they have suffered from the disease since birth, or that it has been genetically inherited.

\section{Analysis}

All of the study participants completed questionnaires designed to measure their personality traits (openness, conscientiousness, extroversion, agreeability, neurotism), percieved social support (family support, friend support, other support) and selfefficacy. The results were analyzed by calculation of $t$ - criterion and Pearson correlation coefficients. Data processing was with SPSS (Statistical Package for the Social Sciences) program.

\section{Measures}

1. The Big Five Inventory ([BFI] Benet-Martinez \& Johnmo, 1998), adapted in Latvian language (Schmitt Allik, McCrae, Benet-Martinez, Alcalay, Ault, Austers, 2007; Perepjolkina \& Kalis, 2011).

The questionnaire includes 44 items, which comprise five personality factors Extraversion, Openness, Neurotism, Conscientiousness and Agreeableness. The items are marked on a Likert-type scale, ranging from 1 (disagree) to 5 (agree). The Cronbah's alphas for the present study were as follows: Extraversion .87, Openness to Experience .77, Neurotism .91, Conscientiousness .76, Agreeableness .72.

2. Multidimentional Percieived Scale Of Social Support (/ MSPSS /; Zimet, Dahlem, Zimet, \& Farley, 1988), adapted in Latvian language (Voitkane, 2001).

The questionnaire consists of 12 items that measure an individual's perceived social support within three dimensions/subscales: perceived social support from family; perceived social support from friends; and perceived social support from other people. Responses to the items are rated on a seven-point Likert-type scale. Responses to the questionnaire assessed seven-point Likert scale, where -3 - " Strongly disagree " -2 -" Tend to disagree ", -1 -" Tend to disagree that I agre e with " 0 - "Difficult to say " 1 - "Rather agree disagreement " 2 - " Rather agree 
" 3 - " Strongly agree ". The Cronbah's alphas for the present study were as follows: overall .74, perceived social support from family .90 , perceived social support from friends .92, perceived social support from others .93 .

3. General Self-Efficacy Scale (Schwarzer \& Jerusalem, 1995), adapted in Latvian language (Bulina, 2009).

The survey is one-dimensional and consists of 10 claims to be assessed in Likert-type scale of 1 to 4 , with 1 - "not at all " to 4 - "fully consistent with". In order to achieve a universal self-efficacy score, the ratings were summed. The total Cronbach's alpha was .89.

4. Demographic survey - gender, age, education, monthly income, diagnosis, how long the person had been suffering from the diagnosed disease, and what were the main difficulties encountered as a result of the disease.

\section{Procedure}

Measurements were collected either in the hospital or in the internet environment. Questionnaire completion time was not limited.

\section{Ethical approval}

Conducting of the study in the hospital was approved by the Riga Eastern Clinical University Hospital Ethics Committee.

\section{Results}

In order to answer the first research question - Is there a difference in personality trait ratings, perceived social support and self-efficacy reported by people with and without chronic disease? comparisons were made by calculation of the $\mathrm{t}$-criterion indicator (see Table 1).

Table 1. Personality trait, perceived social support and self-efficacy rating comparison for adults with and without chronic disease

\begin{tabular}{lccccc}
\hline & $\begin{array}{c}\text { Adults without chronic dis- } \\
\text { eases }(\boldsymbol{n}=\mathbf{5 0})\end{array}$ & $\begin{array}{c}\text { Adults with chronic diseases } \\
(\boldsymbol{n}=\mathbf{5 0})\end{array}$ \\
\hline Self-efficacy & $\boldsymbol{M}$ & $\mathrm{SD}$ & $\boldsymbol{M}$ & $\mathrm{SD}$ & $\boldsymbol{t}$ \\
Support from family & 32.62 & 5.37 & 30.22 & 5.37 & $\mathbf{2 . 2 4 ^ { * }}$ \\
Support from friends & 5.46 & 6.23 & 3.58 & 6.67 & 1.45 \\
Support from other people & 4.50 & 6.46 & 33,70 & 6.48 & $\mathbf{2 . 2 2 ^ { * }}$ \\
Openess & 6.12 & 6.91 & 1.62 & 7.62 & 1.22 \\
Conscientiousness & 3.56 & .53 & 4.34 & .61 & -.86 \\
Extraversion & 33,70 & .66 & 3.66 & .54 & -.09 \\
Agreeableness & 3.41 & .87 & 33,70 & .82 & 1.15 \\
Neurotism & 3.23 & .60 & 3.42 & .64 & -.17 \\
& 3.48 & .98 & 3.04 & .94 & -1.63 \\
& 3.14 & & 3.51 & & \\
\hline
\end{tabular}

${ }^{*} p<0,05$ 
As seen in Table 1 there are significant differences in the self-efficacy $(\mathrm{t}=2.24$, $\mathrm{p}<0.05)$ and perceived social support from friends $(\mathrm{t}=2.22, \mathrm{p}<0.05)$ among adults with and without chronic diseases. Adults without chronic disease reported higher ratings on self-efficacy $(M=32.62, \mathrm{SD}=5.37)$ than adults with chronic disease $(\mathrm{M}=30.22, \mathrm{SD}=5.37)$. Adults with chronic disease reported lower ratings on perceived social support from friends $(\mathrm{M}=1.62, \mathrm{SD}=6.48)$ than adults without chronic disease. There were no significant differences in personality trait ratings.

In order to answer the second research question - What are the associations between personality trait ratings, perceived social support and self-efficacy for people with and without chronic disease? - Pearson correlations were calculated (see Table 2 and Table 3).

Table 2. Correlations among personality traits, perceived social support and self-efficacy for adults without chronic disease

\begin{tabular}{lccccc}
\hline & Self-efficacy & $\begin{array}{c}\text { Percieved so- } \\
\text { cial support }\end{array}$ & $\begin{array}{c}\text { Percieved social } \\
\text { support from } \\
\text { family }\end{array}$ & $\begin{array}{c}\text { Percieved social } \\
\text { support from } \\
\text { friends }\end{array}$ & $\begin{array}{c}\text { Percieved social } \\
\text { support from } \\
\text { other people }\end{array}$ \\
\cline { 2 - 6 } Self-efficacy & -- & .06 & .04 & .13 & -.01 \\
Openess &. $\mathbf{4 3}^{* *}$ & .04 & .00 & .06 & .05 \\
Conscientiousness &. $\mathbf{2 8 ^ { * }}$ & .12 & .00 & .17 & .12 \\
Extraversion & .23 & .12 & .08 & .13 & .09 \\
Agreeableness & -.02 & .07 & .07 & .01 & .09 \\
Neurotism & $-.39^{* *}$ & -.02 & -.05 & -.08 & .06 \\
\hline
\end{tabular}

${ }^{*} p<0,05,{ }^{* *} p<0,01$

As seen in Table 2, for adults without chronic disease, significant positive correlations were found between self-efficacy and the personality trait ratings of openness $(\mathrm{r}=.43, \mathrm{p}<.01)$ and conscientiousness $(\mathrm{r}=.28, \mathrm{p}<.01)$. A negative correlation was found between self-efficacy and neuroticism $(r=-.39, p<.01)$.

Table 3. Correlations among personality traits, perceived social support and and selfefficacy for adults with chronic disease

\begin{tabular}{|c|c|c|c|c|c|}
\hline & Self-efficacy & $\begin{array}{c}\text { Percieved } \\
\text { social } \\
\text { support } \\
\end{array}$ & $\begin{array}{l}\text { Percieved social } \\
\text { support from } \\
\text { family } \\
\end{array}$ & $\begin{array}{l}\text { Percieved social } \\
\text { support from } \\
\text { friends } \\
\end{array}$ & $\begin{array}{c}\text { Percieved social } \\
\text { support from } \\
\text { other people }\end{array}$ \\
\hline Self-efficacy & -- & .23 & .15 & .20 & .19 \\
\hline Openess & $.40^{\star *}$ & .06 & -.03 & .04 & .12 \\
\hline Conscientiousness & $.38^{\star *}$ & .05 & .02 & .03 & .07 \\
\hline Extraversion & $.28^{*}$ & .20 & -.08 & $.31^{*}$ & .24 \\
\hline Agreeableness & .15 & .24 & .26 & .08 & .22 \\
\hline Neurotism & $-.65^{\star *}$ & .03 & .09 & .02 & .01 \\
\hline
\end{tabular}

${ }^{*} p<0,05,{ }^{* *} p<0,01$

As seen in Table 3, for adults who are suffering from chronic disease, positive correlations were found between self-efficacy and the personality traits of openness 
$(\mathrm{r}=.40, \mathrm{p}<.01)$, conscientiousness $(\mathrm{r}=.38 \mathrm{p}<.01)$ and extraversion $(\mathrm{r}=.28, \mathrm{p}<.01)$. Negative correlations were found between self-efficacy and neurotism $(r=-.65, p<.01)$. Personality trait extraversion ratings were found to positively correlate with perceived social support from friends $(\mathrm{r}=.31, \mathrm{p}<.01)$.

\section{Discussion}

The aim of this study was to examine if there a difference in personality trait ratings, perceived social support and self-efficacy reported by people with and without chronic disease. It was found that people without chronic disease reported higher ratings of selfefficacy and perceived social support from friends. While people with chronic disease reported lower ratings of self-efficacy and perceived social support from friends.

In response to the second research question - What is the relationship between personality traits ratings, perceived social support and self-efficacy for people with and without chronic disease? - it was found that in the group of people who are not suffering from chronic disease higher ratings of self-efficacy were associated with higher ratings of openness and conscientiousness, and lower ratings of neurotism.

Meanwhile, in the group of people who suffer from chronic disease, higher ratings of self-efficacy were associated with higher ratings of openness, conscientiousness and extraversion, and lower ratings of neurotism. It is important to note that in this group higher level of extraversion were associated with higher level of percieved social support from friends.

The results from this study coincide with previous studies examining the relationships between personality traits and self-efficacy, whereby it was concluded that self-efficacy is likely to reinforce certain expressions of personality traits, and that self-efficacy is related not only to stress but also to psychological well-being in general (Axelsson, Lotvall, Cliffordson, Lundgren, \& Brink, 2013; Ebstrup, Eplov, Pisinger, Jorgensen, 2011; Strobel, Tumasjan, \& Sporrle, 2010).

Consistent support from others can positively influence patients who suffer from chronic disease, and motivate them to engage in their own health. Furthermore, self-efficacy contributes to the patient's confidence in their own ability to function in a healthy manner, and to perceive the changes taking place in conjunction with daily difficulties (Lorig, Stewart Ritter, Gonzalez, Laurent, \& Lynch, 1996; Yoo, Kim, Jang, \& You, 2011). Self-efficacy promotes improvements or at least stabilazes the patients' current state of health (Weng, Dai Huang, Chiang, 2010, as referred to Yoo, Kim, Jang, \& You, 2011).

Analyzing the study limitations, the aspects which could have affected the results of this study, it should be noted that in the group of people with chronic disease there were people with various chronic disease diagnoses, mostly with chronic pain, asthma, psoriasis, diabetes and arthritis diagnoses. In further more extensive studies there could be separate analysis of how different diagnosis could affect self-efficacy and personality traits. Future studies should take into account additional aspects, such as the diagnosis of the disease, how long a person is suffering from disease, the environment in which they live, marital status, medication habits or amount of drugs taken. The main aim of 
this study was to find out in general - whether there are differences in how between people with and without chronic disease evaluate their self-efficacy, personality traits and social support. It may be that by increasing the number of respondents in both groups there may be more noticeable difference in the ratings between the two groups. In future studies the sample size should be increased.

The strengths of this study are that this is one of the first studies in Latvia concerning the psychological aspects of people suffering from chronic disease, and the first study to specifically examine the relationships between self-efficacy, personality traits and social support within this group. Another benefit of this study is that it can serve as the basis for the development of rehabilitation programs for people with chronic disease, and for providing information to those professionals who work with them in treatment. Such information can be helpful not only for psychotherapists, psychologists and social workers, but also for the medical staff. The study also provides an opportunity to educate other specialists and family members, relatives and friends about enhancing the psychological well-being of people with chronic disease.

The results of the study indicate that for people who suffer from chronic disease it is important to reach out to other for social support, as this may increase one's selfefficacy, especially as one becomes more open to engagement with others. 
Frequency of chronic disease diagnosis for the research participants with chronic disease

\begin{tabular}{lc}
\hline \multicolumn{1}{c}{ Diagnosis } & $\begin{array}{c}\text { Adults } \\
\text { with chronic disease } \\
(n=50)\end{array}$ \\
\hline Psoriasis & 5 \\
Diabetes & 5 \\
Asthma & 9 \\
Migraine & 1 \\
Arthritis & 5 \\
Haemophilia A & 2 \\
Renal failure & 1 \\
Celiac disease & 2 \\
Thyroiditis & 1 \\
Ankylosing Spondilitis & 1 \\
Chronic heart disease & 1 \\
Heart Atrial fibrillation & 1 \\
Chronic pain & 10 \\
Neural amyotrophy & 1 \\
Chronic Vulvovaginal Candidiasis & 1 \\
Freiberg disease (pain syndrome) & 1 \\
Chronic Reflux disease & 1 \\
Hypertension & 1 \\
Vegetative dystonia & 1 \\
\hline
\end{tabular}

Appendix 2

Demographic indicators of age, educational and income level for study participants with and without chronic diseases

\begin{tabular}{lcc}
\hline \multicolumn{1}{c}{ Average age and education level } & $\begin{array}{c}\text { Adults } \\
\text { without chronic } \\
\text { diseases }(n=50)\end{array}$ & $\begin{array}{c}\text { Adults } \\
\text { with chronic } \\
\text { diseases }(n=50)\end{array}$ \\
\hline $\begin{array}{l}\text { Average age in group } \\
\text { Education level: }\end{array}$ & 29,92 & 31,32 \\
Secondary/Professional education & $24,5 \%$ & $28 \%$ \\
Higher education (Bachelor/Professional Bachelor) & $38,8 \%$ & $40 \%$ \\
Master/Doctorate & $16,3 \%$ & $22 \%$ \\
Incomplete higher education & $20,4 \%$ & $10 \%$ \\
& & \\
Income level (monthly): & & $28 \%$ \\
$360-500$ eur & $26 \%$ & $20 \%$ \\
$500-800$ eur & $30 \%$ & $14 \%$ \\
$800-1000$ eur & $8 \%$ & $18 \%$ \\
1000 eur and more & $20 \%$ & $20 \%$ \\
Do not work & $16 \%$ & \\
\hline
\end{tabular}




\section{References}

Aalto A. M., Uutela A., \& Aro A. R. (1997). Health related quality of life among insulin-dependent diabetics: Disease-related and psychosocial correlates. Pat Ed \& Counseling, 30: 215-225.

Aljasem L. I., Peyrot M., Wissow I., \& Rubin, R. R. (2001). The impact of barriers and self-efficacy on self care behaviours in type 2 diabetes. The Diabetes Educator, 27 (3), 393-404.

Attree E. A., Arroll M. A., Dancey C. P., Griffith C., \& Bansal A. S. (2014). Psychosocial factors involved in memory and cognitive failures in people with myalgic enchepalomyelitis/chronic fatigue syndrome. Dove press Journal: Psychology Research and Beahvior Management, 7, $67-76$.

Axelsson M., Lotvall J., Cliffordson J. L., \& Brink E. (2013). Self-efficacy and adherence as mediating factors between personality traits and health-related quality of life. Quality of Life Research, 22: 567-575.

Bandura A. (1977). Self-efficacy: Toward a unifying theory of behavioral change. Psychological Review; 84: 191-215.

Banerjee U., Bhattacharya N. K., \& Sanyal N. (2014). Stress, coping and emotional processing in chronic pain: a comporative analysis. Psychology \& Mental Health, 2, 104-112.

Barbee A. P., Cunningham M. R., Winstead B. A., Derlega V. J., Gulley M. R., Yankeelov P. A. (1993). Effects of gender role expectations on the social support process. Journal of Social Issues, 49 (3), 175-190.

Barger S. D. (2006). Do psychological characteristics explain socioeconomic stratification of selfrated health? Journal of Health Psychology, 11, 21-35.

Barrera M. J. (1986). Distinctions between social support concepts, measures, and models. American Journal of Community Psychology, 14, 413-425.

Belgrave F. Z., \& Washington, A. (1986). The Relationship between locus of control and select personality traits in two chronically adolescent patient groups. Journal Of Rehabilitation, 52(4).

Belle D. (1987). Gender differences in the social moderators of stress. In R. C. Barnett, L. Biener, \& G. K. Baruch (Eds.), Gender and stress (pp. 257-277). New York: Free Press.

Benyamin Y., Idler, E. L., Leventhal, H., \& Leventhal, E. A. (2000). Positive affect and function as influences on self-assessments of health: Expanding our view beyond illness and disability. Journals of Gerontology. Series B, Psychological Sciences and Social Sciences, 55, 107-116.

Bogg T., \& Roberts, B. W. (2004). Conscientiousness and health-related behaviors: A metaanalysis of the leading behavioral contributors to mortality. Psychological Bulletin, 130, 887-919.

Brannon L., \& Feist, J. (2000). Health Psychology: An Introduction to behavior and Health (Fourth ed.). United States of America, Wadsworth, a division of Thomson Learning. Bulletin, $126,3-25$.

Chapman B. P., Duberstein, P. R., \& Lyness, J. M. (2007). The distressed personality type: Replicability and general health associations. European Journal of Personality, 21, 1-19.

Chapman B., Duberstein, P., \& Lyness, J. M. (2007). Personality traits, education, and healthrelated quality of life among older adult primary care patients. The Journals of Gerontology: Series B, Psychological Science and Social Science, 62(6), 343-352.

Choi J. H., Chung, K., \& Park, K. (2013). Psychosocial predictors of four health-promoting behaviors for cancer prevention using the stage of change of Transtheoretical Model. PsychoOncology, 22 (10), 2253-2261. 
Christensen A. J., \& Smith, T. W. (1995). Personality and patient adherence: Correlates of the five-factor model in renal dialysis. Journal of Behavioral Medicine, 18, 305-313.

Clark N. M., Becker M. H., Janz N. K., Lorig K., Rakowski W., \& Anderson L. (1991). Selfmanagement of chronic disease by older adults. Journal of Aging and Health 3: 3-27.

Cobb S. (1976). Social support as a moderator of life stress. Psychosomatic Medicine, 38 (5), 300-314.

Costa P. T., Jr., \& McCrae, R. R. (1994) Set like plaster? Evidence for the stability of adult personality. In T. Heatherton and J. Weinberger (eds.), Can personality change? Washington, DC: American Psychological Association.

Costa P. T., \& McCrae, R. R. (1992). Revised neo personality inventory and neo five factor inventory:Professional manual. Odessa, FL: Psychological Assessment.

Cutrona C. E,. \& Russell, D. W. (1990). Type of social support and specific stress: Toward a theory of optimal matching. In: Sarason, G., Sarason, B. R., \& Pierce, G. R. (Eds.), Social Support: An Interactional View, 319-366. New York: Wiley.

Cwikel J. M., Dielman T. E., Kirsch J. P., \& Israel B. A. (1988). Mechanisms of psychosocial effects on health: the role of social integration, coping style, and health behaviour. Health Education Quarterly, 15, 151-173.

de la Iglesia G., Stover J. B., Liporace M. F. (2014). Perceived social support and academic achievement in Argentinean College students. European Journal of Psychology, Vol. 10 (4), 637-649.

Deary I. J., Weiss, A., \& Batty G. D. (2010). Intelligence and personality as predictors of illness and death: How researchers in differential psychology and chronic disease epidemiology are collaborating to understand and adress health inequalitues. Psychological Science in the Public Interest, vol. 11, no. 2. 53-79.

DiClemente C. C., Prochaska J. O., \& Gibertini M. (1985). Self-efficacy and the stages of selfchange of smoking. Cognitive Therapy and Research, 9, 181-200.

Ebstrup J. F., Eplov L. F., Pisinger C., \& Jorgensen T. (2011). Association between the Five Factor personality traits and perceived stress: is the effect mediated by general self-efficacy? Anxiety, Stress and Coping, 6, 1-13.

Engel G. L.(1980). The Clinical application of the biopsychosocial model. Am J Psychiatry 137:5, The American Journal of Psychiatry, 535.

Evers A. W. M., Zautra A., \& Thieme K. (2011). Stress and resilience in rheumatic diseases: a review and glimpse into the future. Nature Reviews Rheumatology 7, 409-415.

Fisher E. B., Arfken C. L., Heins J. M., Houston C. A., Jeffe D. B., \& Sykes R. K. (1997). Acceptance of diabetes regimens in adults, in Gochman DS (ed.): Handbook of health behavior research II: Provider determinants. New York: Plenum, 189-212.

Fordyce W. E, Fowler R. S., \& DeLateur B. (1968). An application of behavior modification technique to a problem of chronic pain. Behaviour Research and Therapy, 6 (1), 105-107.

Fordyce W. E, Fowler R. S., Jr. Lehmann J. F., Delateur B. J., Sand P. L., \& Trieschmann R. B. (1973). Operant conditioning in the treatment of chronic pain. Archives of Physical Medicine and Rehabilitation, 54 (9), 399-408.

Frank P., Chapman B., Duberstein P., \& Jerant A. (2009). Five factor model personality factors moderated the effects of an intervention to enhance chronic disease management self-efficacy. British Journal of Health Psychology, 14 (Pt 3), 473-487. 
Gallant M. P. (2003). The influence of social support on chronic illness self-management: A review and directions for research. Health Education and Behavior, 30, 170.

Gatchel R. J., \& Turk D. C. (1996). (eds), Psychological approaches to pain management: A Practitioner's Handbook. New York: Guilford.

Go A. S., Mozaffarian D., Roger V. L., Benjamin E. J., Berry J. D., Borden W. B., Bravata D. M., Dai S., Ford E. S., Fox C. S., Franco S., Fullerton H. J., Gillespie C., Hailpern S. M., Heit J. A., Howard V. J., Huffman M. D., Kissela B. M., Kittner S. J., Lackland D. T., Lichtman J. H., Lisabeth L. D., Magid D., Marcus G. M., Marelli A., Matchar D. B., McGuire D. K., Mohler E. R., Moy C. S., Mussolino M. E., Nichol G., Paynter N. P., Schreiner P. J., Sorlie P. D., Stein J., Turan T. N., Virani S. S., Wong N. D., Woo D., \& Turner M. B. (2013). American heart association statistics committee and stroke statistics subcommittee. Executive summary: Heart disease and stroke statistics - 2013 update: a report from the American Heart Association. Circulation 127, 143-152.

Hoffman C., \& Rice, D. (1996). Chronic care in America: A 21'st: Century challenge. Princeton, New Jersey: The Institute for Health \& Aging.

Holloway A., \& Watson H. E. (2002). Role of self-efficacy and behaviour change. Journal of Nursing Practice, 8 (2), 106-115.

Hudek-Knezevic J., \& Kardum I. (2009). Five-factor personality dimensions and 3 health-related personality constructs as predictors of health. Public Health, 50, 394-402.

Jackson T. P., Stabile V. S., \& McQueen K. K. A.(2014). The Global Burden of Chronic Pain. Chair, Committee on Global Humanitarian Outreach. June 1, Volume 78 Number 6.

Jensen M. P., \& Turk D. C. (2014). Contributions of psychology to the understanding and treatment of people with chronic pain. American Psychologist, Vol. 69, no. 2, 105-118.

Jensen M. P., Nielson W. R., Kerns R. D. (2003). Toward the development of a motivational model of pain self-management. Pain, 4: 477-492.

Jerant A., Chapman B., Duberstein P., \& Frank P. (2010). Effects of personlaity on self-rated health in a 1-year randomized controlled trial of chronic illness self-management. British Journal of Health Psychology, 15, 321-335.

Jerant A., Moore M., Lorig K., \& Frank P. (2008). Perceived control moderated the self-efficacyenhancing effects of a chronic illness self-management intervention. Chronic Illness, 4 (3), 173-182.

Jokela M., Hakulinen C., Singh-Manoux A., \& Kivimäki M. (2014). Personality change associated with chronic diseases: pooled analysis of four prospective cohort studies. Psychological Medicine (2014), 44, 2629-2640. Cambridge University Press.

Kaplan R. M., \& Hartwell S. L. (1987). Differential effects of social support and social network on physiological and social outcomes in men and women with type II diabetes mellitus. Health Psych 6: 387-398.

Karoly P., \& Ruehlman, L. (2006). Psychological "resilience" and its correlates in chronic pain: Findings from a national community sample. Pain, 123, 90-97.

Kaul T. (2010). Helping Africam American children self-manage asthma : The importance of self-efficacy. Journal of School Health, Vol. 81, no. 1, 29-33.

Keefe F. J., \& Bradley L. A. (1984). Behavioral and psychological approaches to the assesment and treatment of chronic pain. General Hospital Psychiatry, 6 (1), 49-54.

Kinicki A. J., \& McKee F. M. (1996). Annual review, 1991-1995: Occupational health. Journal of Vocational Behavior, 49, 190-220. 
Kratz A. L., Molton I. R., Jensen M. P., Ehde D. M., \& Nielson W. R. (2011). Further evaluation of the motivational model of pain self-management: coping with chronic pain in multiple sclerosis. Behavioural Medicine, 41, 391-400.

Kristofferzon M., Lindqvist, R., \& Nilsson, A. (2011). Relationships between coping, coping resources and quality of life in patients with chronic illness: a pilot study. Scandinavian Journal Of Caring Sciences, 25 (3), 476-483.

LaRocco J. M., House J. S., \& French H. R. P., Jr. (1980). Social support, occupational stress, and health. Journal of Health and Social Behavior, 21, 202-218.

Lazarus R., \& Folkman, S. (1984). Stress, appraisal and coping. New York: Springer.

Levy R. L. (1983). Social support and compliance: A selective review and critique of treatment integrity and outcome measurement. Social Science and Medicine, 17: 1329-1338.

Litt M. D. (1988). Self-efficacy and perceived control: Cognitive mediators of pain tolerance. Journal of Personality and Social Symposium, 410-414.

Loeser J., \& Turk D. C. (2003). Multidisciplinary pain management. In J. Loeser, S. Batler, C. Chapman, \& D. C. Turk (eds), Bonica's management of pain. Philadelphia: Lippincott Williams and Wilkins.

Lorig K., Stewart A., Ritter P., Gonzalez V., Laurent D., \& Lynch J. (1996). Outcome measures for health education and other health care interventions. Thousand Oaks, CA, USA: SAGE Publications.

Marks R., Allegrante J. P., \& Lorig K.(2005). A review and synthesis of research evidence for self-efficacy-enhancing interventions for reducing chronic disability. Implications for health education practice (part II). Health Promotion Practice, 6 (2), 148-156.

McCathie H. C. F., Spence S. H., \& Tate R. L. (2002). Adjustment to chronic obstructive pulmonary disease: the importance of psychological factors. European Respiratory Journal 19, 47-53.

McClelland L. E., \& McCubbin J. A. (2008). Social influence and pain response in women and men. Behavioural Medicine, 31: 413-420.

McCrae R. R., \& Costa, P. T., Jr. (2003). Personality in adulthood: A Five-Factor Theory Perspective, The Guilford Press. A Division of Guilford Publications, Inc. 72 Spring Street, New York, NY 10012.

Melzack R., \& Wall P. D. (1965). Pain mechanisms: A new theory. Science, 150(3699), 971-979.

Nestmann F., \& Schmerl, C. (1991). The lady is not for burning - the gender paradox in prevention and social support. In G. Albrecht H., Otto S., Karstedt-Henke, \& K. Bollert (Eds.), Socialprevention and the social sciences: Theoretical controversies, research problems, and evaluation strategies (pp. 217-234). New York: Walter de Gruyter.

Newton-John T. R., Mason C., \& Hunter M. (2014). The role of resilience in adjustment and coping with chronic pain. Rehabilitation Psychology, Vol. 59, no. 3, 360-365.

Nicholas M. K., Linton, S. J., Watson, P. J., \& Main, C. J. (2011). Early identification and management of psychological risk factors ("yellow flags") in patients with low back pain: A reappraisal. Physical Therapy, 91, 737-753.

Novy D. M., Nelson D. V., Francis D. J., \& Turk D. C. (1995). Perspectives of chronic pain: An evaluative comparison of restrictive and comprehensive models. Psychological Bulletin, 118: 238-247.

Nurullah A. S. (2012). Received and provided social support: A review of current evidence and future directions. American Journal of Health Studies, 27 (3). 
O’Halloran P. D., Blackstock F., Shields N., Holland A., Iles R., Kingsley M., Bernhardt J., Lannin N., Morris M. E., \& Taylor N. F. (2014). Motivational interviewing to increase physical activity in people with chronic health conditions: a systematic review and meta-analysis. Clinical Rehabilitation, Vol. 28 (12), 1159-1171.

Olstad R., Sexton H., \& Sogaard J. (2001). The Finnmark study. A prospective population study of the social support buffer hypothesis, specific stressors and mental distress. Social Psychiatry and Psychiatric Epidemiology, 36, 582-589.

Penley J. A., Tomaka J., Wiebe J. S. (2002). The association of coping to physical and psychological health outcomes: a meta-analytic review. Journal of Behavioral Medicine 25, 551-603.

Perquin C. W., Hazebroek-Kampschreur A. A., Hunfeld J. A., Bohnen A. M., van SuijlekomSmit L. W., Passchier J., \& van der Wouden J. C. (2000). Pain in children and adolescents: A common experience. Pain, 87 (1), 51-58.

Roberts B. W., \& DelVecchio, W. F. (2000). The rank-order consistency of personality traits from childhood to old age: A quantitative review of longitudinal studies. Psychological Bulletin, Vol. 126, No. 1, 3-25.

Roberts B. W., Walton, K. E., \& Viechtbauer, W. (2006). Patterns of mean-level change in in personality traits across the life course: A meta-analysis of longitudinal studies. Psychological Bulletin, Vol 132 (1), 1-25.

Sarason B. R., Sarason, I. G., Hacker, T. A., \& Basham, R. B. (1985). Concommitants of social support: Social skills, physical attractiveness, and gender. Journal of Personality and Social Psychology, 49, 469-480.

Schafer L. C., McCaul K. D., \& Glasgow R. E. (1986). Supportive and nonsupportive family behaviors: Relationships to adherence and metabolic control in persons with Type I diabetes. Diabetis Care 9: 179-185.

Schwarzer R., \& Hallum S. (2008). Perceived teacher self-efficacy as a predictor of job stress and burnout: mediation analyses. Applied Psychology, 57: 152-171.

Sharpe L., \& Curran L. (2006). Understanding the process of adjustment to illness. Social Science and Medicine 62, 1153-1166.

Smith T. W., \& Williams P. G. (1992). Personality and health: Advantages and limitations of the five-factor model. Journal of Personality, 60 (2), 395-423.

Stokes J. P., \& Wilson D. G. (1984). The inventory of socially supportive behaviors: Dimensionality, prediction, and gender differences. American Journal of Community Psychology, 12, 53-69.

Strobel M., Tumasjan A., \& Sporrle M. (2010). Be yourself, believe in yourself, and be happy: Self-efficacy as a mediator between personality factors and subjective well-being. Scandinavian Journal of Psychology, 52 (1), 43-48.

Strong K., Mathers C., Leeder S., \& Beaglehole R. (2005). Preventing chronic diseases: how many lives can we save? Lancet 366, 1578-1582.

Turk D. C., Meichenbaum D., \& Genest M. (1983). Pain and behavioral medicine: A cognitivebehavioral perspective. New York, NY: Guilford Press.

Turner J. A. (1982). Comparison of group progressive-relaxation training and cognitivebehavioral group therapy for chronic low back pain. Journal of Consulting and Clinical Psychology, 50 (5), 757-765.

Vilhena E., Pais-Ribeiro J., Silva I., Pedro L., Meneses R. F., Cardoso H., daSilva A. M., \& Mendonca D. (2014). Psychosocial factors as predictors of quality of life in chronic portugese patients. Health and Quality of Life, 12:3. 
Wallston B. S., Alagna S. W., DeVellis B. M., \& DeVellis R. F. (1983). Social support and physical health. Health Psychology, 2, 367-391.

Warwick R., Joseph S., Cordle C., \& Ashworth P. (2004). Social support for women with chronic pelvic pain: what is helpful from whom? Psychology of Health, Vol.19, no. 1, 117-134.

Weng L. C., Dai Y. T., Huang H. L., Chiang Y. J. (2010). Self-efficacy, self-care behaviours and quality of life of kidney transplantē recipients. Journal of Advanced Nursing, 66: 828-838.

Williams P. G., O'Brien C. D., \& Colder C. R. (2004). The effects of neuroticism and extraversion on self-assessed health and health-relevant cognition. Personality and Individual Differences, 37 (1), 83-94.

Yoo H., Kim C. J., Jang Y., \& You M. (2011). Self-efficacy associated with self-management behaviours and health status of South Koreans with chronic diseases. International Journal of Nursing Practice, 17, 599-606. 



\section{Notes for authors}

The "Baltic Journal of Psychology" is published by the Department of Psychology, Faculty of Education and Psychology, University of Latvia. The journal publishes original papers on current issues in psychology as well as empirical, theoretical, and practical articles on broad aspects of psychology. It will appear two times a year.

\section{Information for authors on submitting manuscripts:}

Contributions, written in English or Latvian, should follow the general style described in the Publication Manual of the American Psychological Association ( $6^{\text {th }}$ ed. 2008).

Manuscripts should not exceed 8000 words, should be typed on $(21 \times 29.7 \mathrm{~cm})$ white bond paper, double-spaced, with font size 12, and with margins of at least $2.54 \mathrm{~cm}$ on all four sides. Acceptable typefaces are Times Roman or Courier. Three copies of each manuscript including electronic version on disk should be submitted. Disks can be of any standard size, IBM compatible, written in Word for Windows. Manuscripts will not be returned to authors.

Title page for the manuscript should show the title of the article, the name(s) and affiliation(s) of the authors, running head and, at the bottom of the page, the name and address of the person (including postal code and electronic mail address) to whom proofs and reprint requests should be sent.

An abstract of up to 150 words should follow the title page on a separate page. A list of 3-10 key words should be provided directly below the abstract.

Each table should be numbered and referred to by number in the text. Each table should be typed on a separate page and have a descriptive title.

Each illustration (diagram, chart, photograph, and drawing) should be numbered and referred to by number in the text. Each table should be typed on a separate page and have a descriptive title.

References are given at the end of the text. All references cited in the text must appear in the reference list in APA format.

Authors should submit a brief biographical statement (8-10 lines) for inclusion in the section "Notes on Authors".

There is no payment for published papers. The authors will receive 2 reprints, free of charge. 


\section{Baltic JOURNAL OF PSYCHOLOGY}

\section{LATVIJAS}

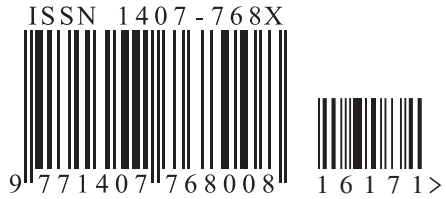

\section{Baltijas PSIHOLOG̦IJAS ŽURNĀLS}

